\title{
Synthesis of novel polycyclic aromatic compounds via cascade cyclizations of benzannulated enyne-allenes
}

\author{
Yanzhong Zhang \\ West Virginia University
}

Follow this and additional works at: https://researchrepository.wvu.edu/etd

\section{Recommended Citation}

Zhang, Yanzhong, "Synthesis of novel polycyclic aromatic compounds via cascade cyclizations of benzannulated enyne-allenes" (2005). Graduate Theses, Dissertations, and Problem Reports. 4207. https://researchrepository.wvu.edu/etd/4207

This Dissertation is protected by copyright and/or related rights. It has been brought to you by the The Research Repository @ WVU with permission from the rights-holder(s). You are free to use this Dissertation in any way that is permitted by the copyright and related rights legislation that applies to your use. For other uses you must obtain permission from the rights-holder(s) directly, unless additional rights are indicated by a Creative Commons license in the record and/ or on the work itself. This Dissertation has been accepted for inclusion in WVU Graduate Theses, Dissertations, and Problem Reports collection by an authorized administrator of The Research Repository @ WVU.

For more information, please contact researchrepository@mail.wvu.edu. 


\title{
Synthesis of Novel Polycyclic Aromatic Compounds via Cascade Cyclizations of Benzannulated Enyne-Allenes
}

\author{
Yanzhong Zhang \\ Dissertation \\ Submitted to the Eberly College of Arts and Sciences \\ at \\ West Virginia University \\ in partial fulfillment of the requirements for the degree of \\ Doctor of Philosophy \\ in Organic Chemistry \\ Kung K. Wang, Ph. D., Chair \\ Peter M. Gannett, Ph. D. \\ George A. O’Doherty, Ph. D. \\ Jeffrey L. Petersen, Ph. D. \\ Björn C. Söderberg, Ph. D. \\ C. Eugene Bennett Department of Chemistry \\ Morgantown, West Virginia \\ 2005
}

Keyword: Schmittel Cyclization, Enyne-Allenes, Biradical, Helicene Copyright 2005 Yanzhong Zhang 


\section{ABSTRACT \\ Synthesis of Novel Polycyclic Aromatic Compounds via Cascade Cyclizations of Benzannulated Enyne-Allenes}

\section{Yanzhong Zhang}

Under mild conditions, a diindeno-fused $4 H$-cyclopenta[def]phenanthrene was successfully synthesized through the thionyl chloride-induced cascade cyclizations of the corresponding enediynyl propargylic alcohol with the formation of four new rings in one operation. The diindeno-fused $4 H$-cyclopenta[def]phenanthrene has a 41-carbon framework represented on the surface of $\mathrm{C}_{60}$.

A variety of helicenes with one or two phenyl substituents at the most sterically hindered position were also successfully synthesized through a cascade sequence of reactions involving a Schmittel cyclization reaction of the corresponding benzannulated enyne-allenes followed by an intramolecular radical-radical coupling reaction to afford the formal Diels-Alder adducts. The helical structures were produced either by increasing the ortho annulation number of the central aromatic ring systems or by replacing the phenyl substituents with two longer 4-(tert-octyl)phenyl groups.

The structures of these helicenes were established by NMR studies and in some cases were confirmed by X-ray structure analyses. The existence of a helical twist is manifested with a set of $\mathrm{AB}{ }^{1} \mathrm{H}$ NMR signals with a large geminal coupling constant of the diastereotopic methylene hydrogens on the five-membered rings. The racemization barriers of these helicenes were also studied by temperature dependent studies. Due to steric hindrance, the rotation of the phenyl substituent in the helical compounds is restricted. The rotational barriers of the phenyl substituent were also studied by temperature dependent studies. 


\section{Dedicated to}

My wife and my parents 


\section{ACKNOWLEDGEMENT}

I would like to express my sincere appreciation to my research advisor, Dr. Kung K. Wang, for his instructive guidance and continuous encouragement during the course of my dissertation research. His patience and calmness in solving problems and his willingness to share his knowledge have been an inspiration. I was quite fortunate to have been associated with such an outstanding chemist and a patient teacher. I am greatly benefited by his great interest and extensive knowledge of chemistry.

I would also like to express my gratitude to my research committee members, Dr. Peter M. Gannett, Dr. George A. O’Doherty, Dr. Jeffrey L. Petersen, and Dr. Björn C. Söderberg for their helpful suggestions and valuable discussions. My special thanks go to Dr. Jeffrey L. Petersen for his valuable help and excellent work in X-ray structure analysis.

My appreciation is also extended to my group members, Xiaoqing Han, Dr. Hongbin Li, Dr. Xiaoling Lu, Dr. Yonghong Yang, Hua Yang, Weixiang Dai, Daehwan Kim, Yu-Hsuan Wang and many other people for helping me get through my graduate school by making every day special.

My deepest gratitude goes to my wife and my parents for their love, support and encouragement that have made this dissertation possible.

Financial support from the C. Eugene Bennett Department of Chemistry of West Virginia University and the National Science Foundation is also gratefully acknowledged. 


\section{Table of Contents}

Title Page

Abstract

Dedications iii

Acknowledgement iv

Table of Contents $\quad$ V

List of Tables viii

List of Figures viii

List of ${ }^{1} \mathrm{H}$ NMR and ${ }^{13} \mathrm{C}$ NMR Spectra viii

\section{Chapter I}

\section{Cyclization Reactions of Enyne-Allenes}

1. Introduction

2. Myers-Saito $\left(C^{2}-C^{7}\right)$ Cyclization Reaction

3. Schmittel $\left(C^{2}-C^{6}\right)$ Cyclization Reaction

4. Construction of Polycyclic Ring Systems via Schmittel Cyclization of Enyne-Allenes

4.1. Synthesis of Carbocyclic Ring Systems

4.2. Synthesis of Heterocyclic Ring Systems

5. Literature Survey for the Synthetic Methodologies for the Preparation of Enyne-Allenes

\section{Chapter II}

\section{Synthesis of Diindeno-Fused 4H-Cyclopenta[def]phenanthrene} via Benzannulated Enediynyl Propargylic Alcohol

1. Introduction

2. Research Objective

3. Literature Survey for the Synthesis of $4 H$-Cyclopenta[def]phenanthrene

4. Results and Discussion

5. Conclusions 


\section{Chapter III}

\section{Helicenes}

1. Introduction

2. Potential Applications of Helicenes

3. Literature Survey for the Synthesis of Helicenes

3. 1. Approaches for Racemic Helicenes

3. 2. Asymmetric Approaches for Helicenes

\section{Chapter IV}

Studies of Helical Molecules: Synthesis of Indeno-Fused Benzo[c]phenanthrene and Dibenzo[c,g]phenanthrene ([5]Helicene) with a Phenyl Substituent at the Most

\section{Sterically Hindered Position}

1. Introduction

2. Research Objective

3. Literature Survey for the Synthesis Benzo[c]phenanthrene and Derivatives with a Phenyl Substituent at the Most Sterically Hindered Position

4. Results and Discussion

4. 1. Synthesis of Aryl Ketones 160

4. 2. Synthesis of Indeno-fused Phenanthrenes 167

4. 3. Products of $[2+2]$ Cycloaddition Reaction

4. 4. Structure Analysis of $\mathbf{1 6 7}$

5. Conclusions

\section{Chapter V \\ Synthesis of Helical Derivatives of Indenofluorene via Schmittel Cyclization Reaction of Benzannulated Enyne-Allenes}

1. Introduction

2. Research Objective

3. Literature Survey for the Synthesis of the Derivatives of Indenofluorene 
4. Results and Discussion

4. 1. Synthesis of the Compounds of 179a, 182a and $\mathbf{1 8 5}$

4. 2. Structure Analysis of 179a, 182a and $\mathbf{1 8 5}$

4. 3. An Alternative Pathway to Helical Structure

4. 4. Structure Analysis of $\mathbf{1 7 9 b}$ and $\mathbf{1 8 2 b}$

4. 5. Synthesis of Tetraacetylenes $\mathbf{1 7 1}$

5. Conclusions

\section{Chapter VI}

Studies of Helical Molecules: Efficient Synthesis of Overcrowded Molecules of Diindeno-fused 1,12-Diphenylbenzo[c]phenanthrene and

\section{1,14-Diphenyldibenzo[c,g]phenanthrene}

1. Introduction

2. Research Objective

3. Literature Survey for the Synthesis of Overcrowded Molecules

4. Results and Discussion

4. 1. Synthesis of Overcrowded Molecules 204

4. 2. Structure Analysis of 204a and 204b

5. Conclusions

\section{Chapter VII}

\section{Experimental Section}

Instrumentation, Materials and Manipulation

References 


\section{LIST OF TABLES}

Table 1. Synthesis of Phenanthrenes 167a, 167b and 167c

Table 2. Synthesis of 182a and 185

Table 3. Synthesis of $\mathbf{1 7 9 b}$ and $\mathbf{1 8 2 b}$

Table 4. Synthesis of 204b

\section{LIST OF FIGURES}

Figure 1. Thermolysis of (Z)-1,2,4-heptatrien-6-yne 1 in various solvents

Figure 2. Examples of helicenes

Figure 3. ORTEP drawing of the crystal structure of 167a.

Figure 4. Perspective view of the molecular structure of 167c with the thermal ellipsoids scaled to enclose $30 \%$ probability

Figure 5. Examples of Overcrowded Molecules

Figure 6. ORTEP drawing of the crystal structure of 204a with hydrogen atoms omitted for clarity

Figure 7. ORTEP drawing of the crystal structure of 204b with hydrogen atoms omitted for clarity

${ }^{1} \mathrm{H}$ and ${ }^{13} \mathrm{C}$ NMR Spectra of Propargylic trans-Diol 112a

${ }^{1} \mathrm{H}$ and ${ }^{13} \mathrm{C}$ NMR Spectra of Propargylic cis-Diol 112b

${ }^{1} \mathrm{H}$ and ${ }^{13} \mathrm{C}$ NMR Spectra of $4 H$-Cyclopenta[def]phenanthrene 116

${ }^{1} \mathrm{H}$ and ${ }^{13} \mathrm{C}$ NMR Spectra of Benzo[c]phenanthrene-2-carboxylic acid (159c)

${ }^{1} \mathrm{H}$ and ${ }^{13} \mathrm{C}$ NMR Spectra of Aryl Ketone 160a

${ }^{1} \mathrm{H}$ and ${ }^{13} \mathrm{C}$ NMR Spectra of Aryl Ketone 160b

${ }^{1} \mathrm{H}$ and ${ }^{13} \mathrm{C}$ NMR Spectra of Aryl Ketone 160c

${ }^{1} \mathrm{H}$ and ${ }^{13} \mathrm{C}$ NMR Spectra of Ethyl 4-[2-(2-Naphthalenyl)ethynyl]benzoate (163)

${ }^{1} \mathrm{H}$ and ${ }^{13} \mathrm{C}$ NMR Spectra of Ethyl Benzo[c]phenanthrene-2-carboxylate (164)

${ }^{1} \mathrm{H}$ and ${ }^{13} \mathrm{C}$ NMR Spectra of Propargylic Alcohol 165a

${ }^{1} \mathrm{H}$ and ${ }^{13} \mathrm{C}$ NMR Spectra of Propargylic Alcohol 165b

${ }^{1} \mathrm{H}$ and ${ }^{13} \mathrm{C}$ NMR Spectra of Propargylic Alcohol 165c

${ }^{1} \mathrm{H}$ and ${ }^{13} \mathrm{C}$ NMR Spectra of Benzannulated Enediyne 166a 
${ }^{1} \mathrm{H}$ and ${ }^{13} \mathrm{C}$ NMR Spectra of Benzannulated Enediyne 166b

${ }^{1} \mathrm{H}$ and ${ }^{13} \mathrm{C}$ NMR Spectra of Benzannulated Enediyne 166c

${ }^{1} \mathrm{H}$ and ${ }^{13} \mathrm{C}$ NMR Spectra of 7-(1,1-Dimethylethyl)-13-phenyl-8H-indeno[2,1-b]-phenanthrene (167a)

${ }^{1} \mathrm{H}$ and ${ }^{13} \mathrm{C}$ NMR Spectra of 9-(1,1-Dimethylethyl)-15-phenyl-10H-benz[c]indeno[1,2- $\left.h\right]-$ -phenanthrene (167b)

${ }^{1} \mathrm{H}$ and ${ }^{13} \mathrm{C}$ NMR Spectra of Indeno-Fused Dibenzo[c,g]phenanthrene 167c

${ }^{1} \mathrm{H}$ and ${ }^{13} \mathrm{C}$ NMR Spectra of 1,5-Dibromo-2,4-bis(phenylethynyl)benzene (188a)

${ }^{1} \mathrm{H}$ and ${ }^{13} \mathrm{C}$ NMR Spectra of 1,5-Dibromo-2,4-bis[[4-(1,1,3,3-tetramethylbutyl)phenyl]-ethynyl]benzene (188b)

${ }^{1} \mathrm{H}$ and ${ }^{13} \mathrm{C}$ NMR Spectra of 1,5-Bis(trimethylsilylethynyl)-2,4-bis(phenylethynyl)benzene (189a)

${ }^{1} \mathrm{H}$ and ${ }^{13} \mathrm{C}$ NMR Spectra of 1,5-Bis(trimethylsilylethynyl)-2,4-bis[[4-(1,1,3,3-tetramethyl-butyl)phenyl]ethynyl]benzene (189b)

${ }^{1} \mathrm{H}$ and ${ }^{13} \mathrm{C}$ NMR Spectra of 1,5-Diethynyl-2,4-bis(phenylethynyl)benzene (171a)

${ }^{1} \mathrm{H}$ and ${ }^{13} \mathrm{C}$ NMR Spectra of 1,5-Diethynyl-2,4-bis[[4-(1,1,3,3-tetramethylbutyl)phenyl]-ethynyl]benzene (171b)

${ }^{1} \mathrm{H}$ and ${ }^{13} \mathrm{C}$ NMR Spectra of Propargylic Alcohol 172a

${ }^{1} \mathrm{H}$ and ${ }^{13} \mathrm{C}$ NMR Spectra of Propargylic Alcohol 172b

${ }^{1} \mathrm{H}$ and ${ }^{13} \mathrm{C}$ NMR Spectra of Propargylic Alcohol 180a

${ }^{1} \mathrm{H}$ and ${ }^{13} \mathrm{C}$ NMR Spectra of Propargylic Alcohol 180b

${ }^{1} \mathrm{H}$ and ${ }^{13} \mathrm{C}$ NMR Spectra of Propargylic Alcohol 183

${ }^{1} \mathrm{H}$ and ${ }^{13} \mathrm{C}$ NMR Spectra of Tetraacetylenic Hydrocarbon 173a

${ }^{1} \mathrm{H}$ and ${ }^{13} \mathrm{C}$ NMR Spectra of Tetraacetylenic Hydrocarbon 173b

${ }^{1} \mathrm{H}$ and ${ }^{13} \mathrm{C}$ NMR Spectra of Tetraacetylenic Hydrocarbon 181a

${ }^{1} \mathrm{H}$ and ${ }^{13} \mathrm{C}$ NMR Spectra of Tetraacetylenic Hydrocarbon 181b

${ }^{1} \mathrm{H}$ and ${ }^{13} \mathrm{C}$ NMR Spectra of Tetraacetylenic Hydrocarbon 184

${ }^{1} \mathrm{H}$ and ${ }^{13} \mathrm{C}$ NMR Spectra of 179a

${ }^{1} \mathrm{H}$ and ${ }^{13} \mathrm{C}$ NMR Spectra of $\mathbf{1 7 9 b}$ 
${ }^{1} \mathrm{H}$ and ${ }^{13} \mathrm{C}$ NMR Spectra of 182a

${ }^{1} \mathrm{H}$ and ${ }^{13} \mathrm{C}$ NMR Spectra of $\mathbf{1 8 2 b}$

${ }^{1} \mathrm{H}$ and ${ }^{13} \mathrm{C}$ NMR Spectra of $\mathbf{1 8 5}$

${ }^{1} \mathrm{H}$ and ${ }^{13} \mathrm{C}$ NMR Spectra of Aryl Ketone 196a

${ }^{1} \mathrm{H}$ and ${ }^{13} \mathrm{C}$ NMR Spectra of Aryl Ketone 196b

${ }^{1} \mathrm{H}$ and ${ }^{13} \mathrm{C}$ NMR Spectra of Propargylic Alcohol 197a

${ }^{1} \mathrm{H}$ and ${ }^{13} \mathrm{C}$ NMR Spectra of Propargylic Alcohol 197b

${ }^{1} \mathrm{H}$ and ${ }^{13} \mathrm{C}$ NMR Spectra of Benzannulated Enediyne 198a

${ }^{1} \mathrm{H}$ and ${ }^{13} \mathrm{C}$ NMR Spectra of Benzannulated Enediyne 198b

${ }^{1} \mathrm{H}$ and ${ }^{13} \mathrm{C}$ NMR Spectra of 1,12-Diphenylbenzo[c]phenanthrene 204a

${ }^{1} \mathrm{H}$ and ${ }^{13} \mathrm{C}$ NMR Spectra of 1,14-Diphenyldibenzo[c,g]phenanthrene 204b 


\section{Chapter I}

\section{Cyclization Reactions of Enyne-Allenes}

\section{Introduction}

Under thermal conditions, (Z)-1,2,4-heptatrien-6-yne (enyne-allene) 1 could undergo cyclization reaction regioselectively, the reaction could proceed through either the $\mathrm{C}^{2}-\mathrm{C}^{7}$ pathway (Myers-Saito cyclization) leading to the $\alpha, 3$-didehydrotoluene/naphthalene biradical $2^{1}$ or the $C^{2}-C^{6}$ pathway (Schmittel cyclization) affording the fulvene/benzofulvene biradical 3 (Scheme 1). ${ }^{2}$

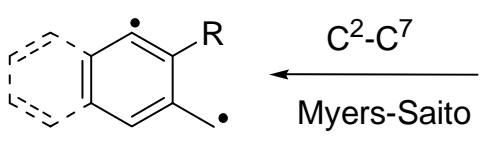

2

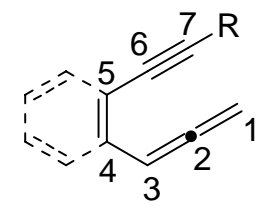

1

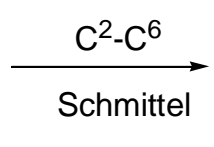

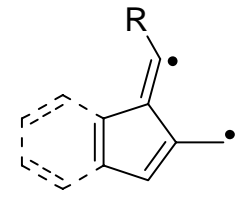

3

Scheme 1. Cyclization reactions of enyne-allenes.

The regioselectivity of the cyclization reaction is controlled by the acetylenic terminal substituent R. With a hydrogen or a sterically non-demanding alkyl group at the acetylenic terminus, the Myers-Saito cyclization reaction is the preferred pathway. Otherwise, with an aryl substituent or a srerically demanding group, such as tert-butyl or trimethylsilyl group, the Schmittel cyclization reaction becomes the favored one.

\section{Myers-Saito $\left(C^{2}-C^{7}\right)$ Cyclization Reaction}

Myers and Saito et al. independently demonstrated that enyne-allene $\mathbf{4}$ undergoes cyclization reaction to form the $\alpha, 3$-didehydrotoluene biradical 5 and then leads to toluene (6) upon hydrogen atom abstraction (Scheme 2).

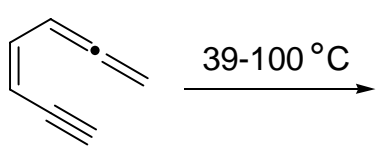

4

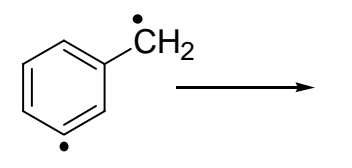

5<smiles>Cc1ccccc1</smiles>

6

Scheme 2. Myers-Saito cyclization reaction.

Mechanistic studies of thermolysis of $\mathbf{4}$ in various solvents were performed (Figure $1)^{1 \mathrm{c}}$ and the biradical intermediate was successfully trapped by 1,4 -cyclohexadiene. Heating a solution of $\mathbf{4}$ in deoxygenated solvents of benzene and 1,4-cyclohexadiene forms toluene (6) 
and adducts $\mathbf{7}$ and $\mathbf{8}$ as the detectable products. Theoretically $\mathbf{7}$ and $\mathbf{8}$ could be formed by either a radical chain aromatization pathway (Scheme 3) or a radical recombination pathway (Scheme 4). But the invariance of the ratio $(7+8) /$ toluene $(6)$ with the concentration of 4 suggests that the former pathway is at best a minor competitor with the simple recombination mechanism. All the products formed by thermolysis of $\mathbf{4}$ in various solvents are consistent with the intermediacy of the $\alpha, 3$-didehydrotoluene biradical 5 .

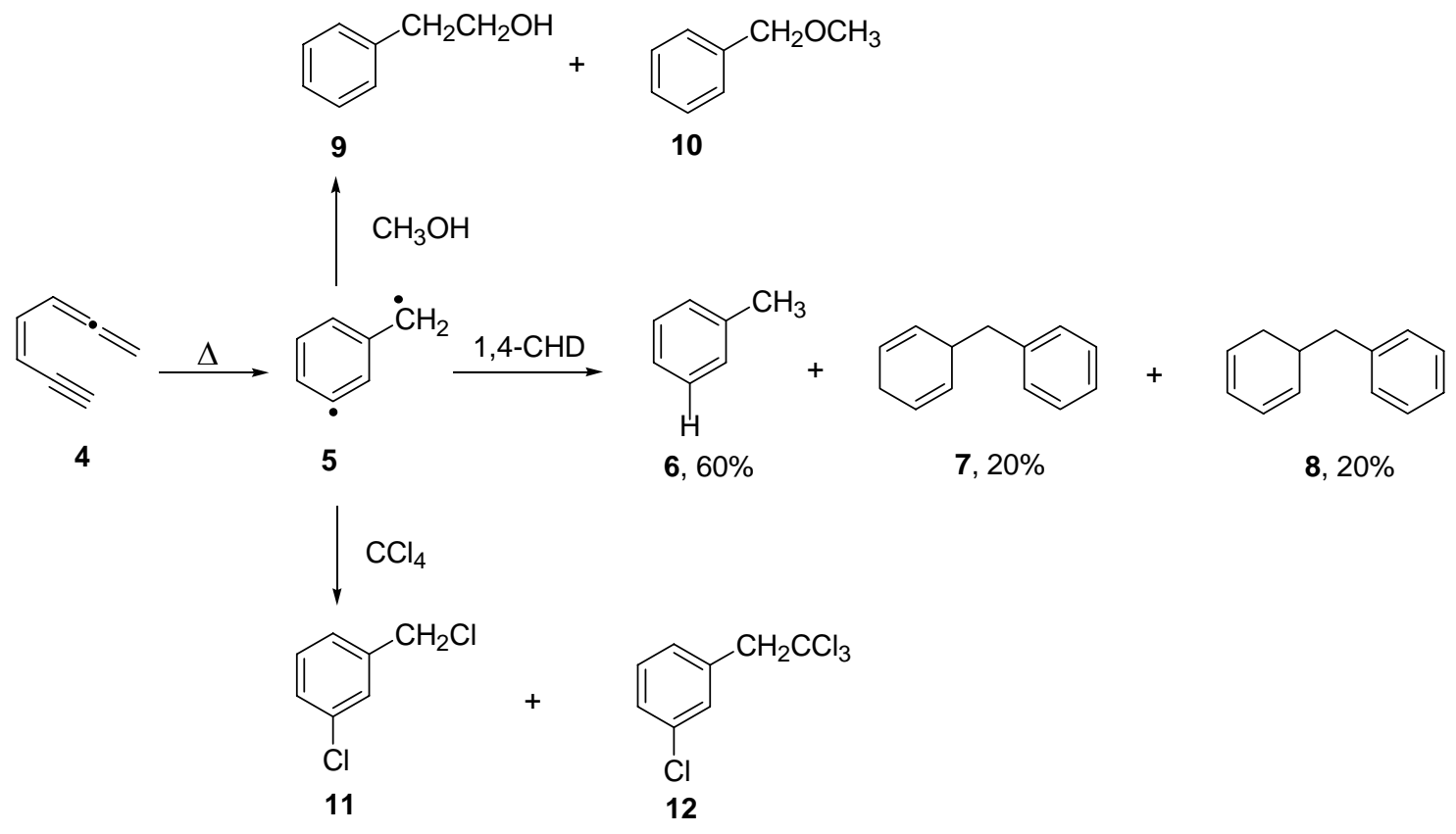

Figure 1. Thermolysis of enyne-allene 4 in various solvents.

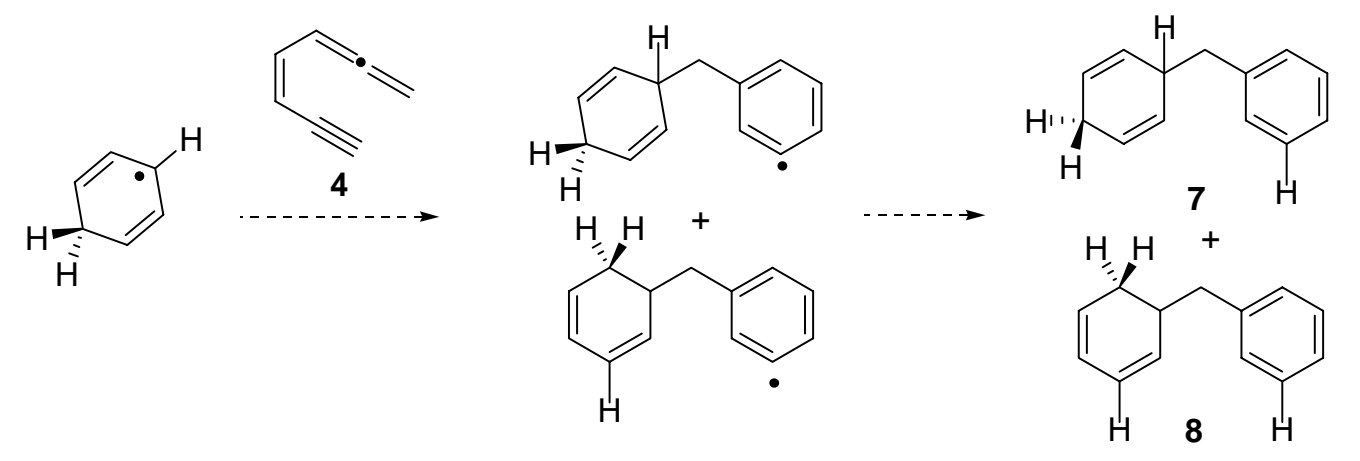

Scheme 3. Mechanism of radical chain aromatization. 


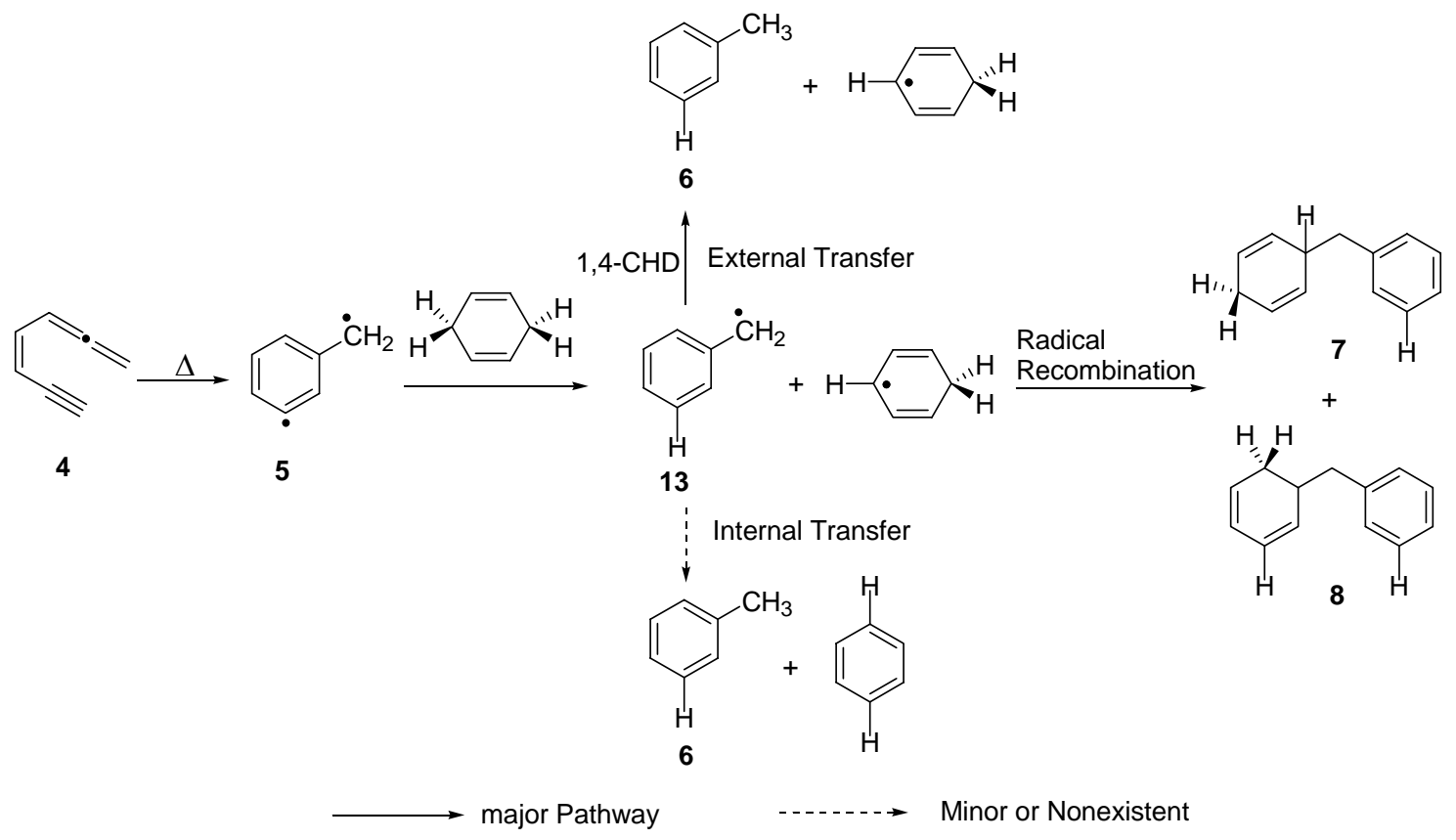

Scheme 4. Mechanism of trapping the $\alpha, 3$-didehydrotoluene biradical with 1,4-CHD.

Myers and coworkers also found out that the cyclization reaction is a first-order reaction with the following activation parameters: $\Delta H^{\ddagger}=21.8 \pm 0.5 \mathrm{kcal} / \mathrm{mol}, \Delta \mathrm{S}^{\ddagger}=-11.6 \pm$ $1.5 \mathrm{eu}\left(E_{\mathrm{a}}=22.5 \mathrm{kcal} / \mathrm{mol}, \log A=10.7\right)$.

Obviously the Myers-Saito cyclization reaction belongs to the family of biradical cyclization reactions such as Bergman cyclization reaction of enediyne 14 (Scheme 5$)^{3}$ and Moore cyclization reaction of enyne-ketene $\mathbf{1 7}$ (Scheme 6). ${ }^{4}$

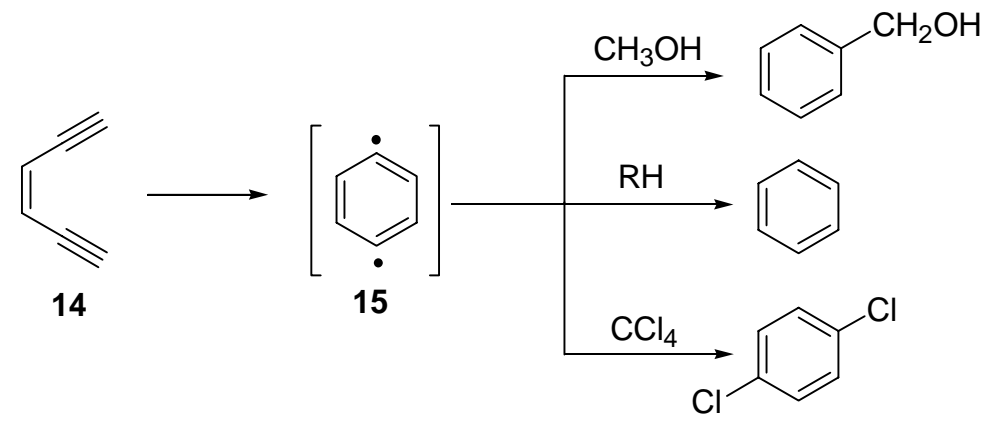

Scheme 5. Bergman cyclization of enediyne 14.

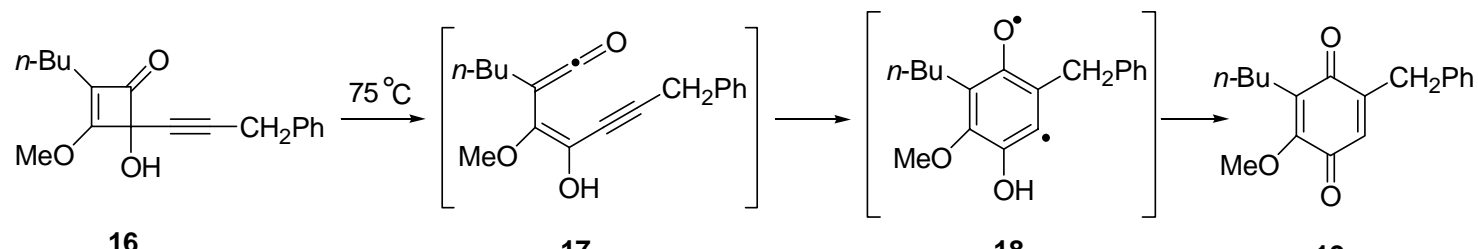

Scheme 6. Moore cyclization of enyne-ketene 16. 
The Myers-Saito and the Bergman cyclization reactions were awarded with substantial interest, because they represent the basis of the antitumor antibiotic efficacy of enyne-allenes and enediynes. For example, the biological activity of NCS chromophore 20 is attributed to its ability to cleave DNA irreversibly. The DNA damage is initiated by a triggering reaction to form a labile intermediate 21. Subsequently a rapid Myers-Saito-type cyclization reaction leads to biradical 22, followed by abstraction of two hydrogen atoms from DNA to cause DNA cleavage (Scheme 7). ${ }^{5}$ Similarly, calicheamicin 24 shows its biological activity through the involvement of a Bergman cyclization reaction (Scheme 8). ${ }^{6}$

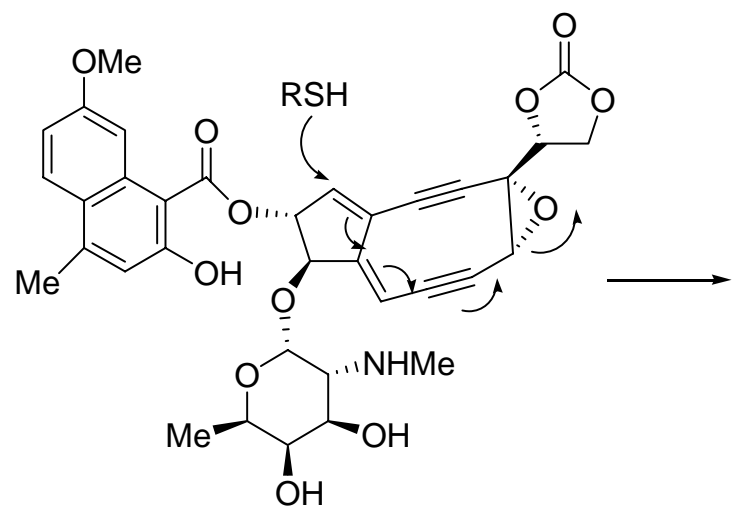

20

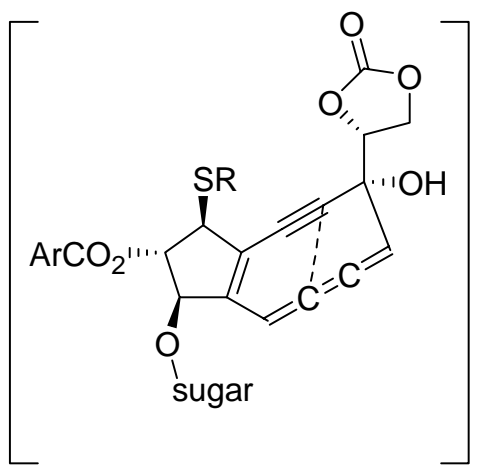

21

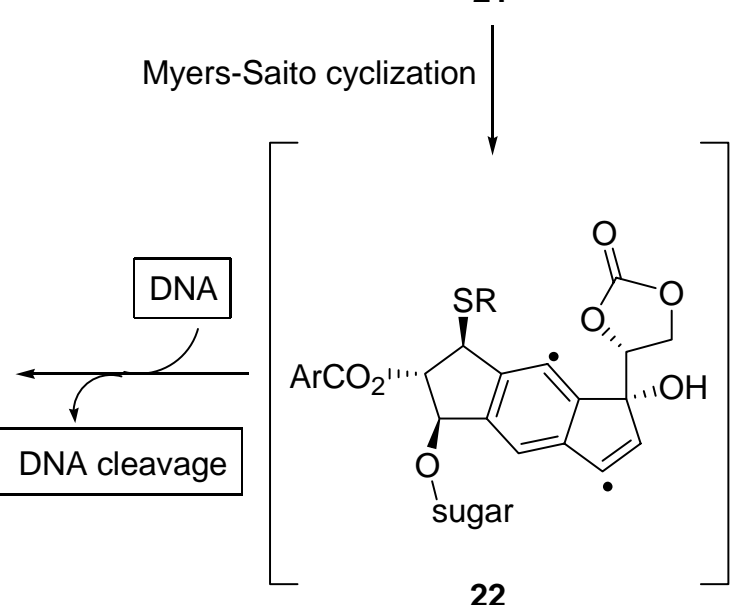

22

23

Scheme 7. Mechanism of DNA cleavage by neocarzinostatin. 


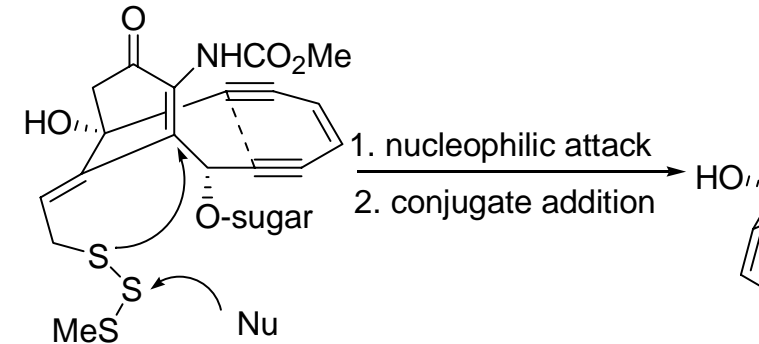

24

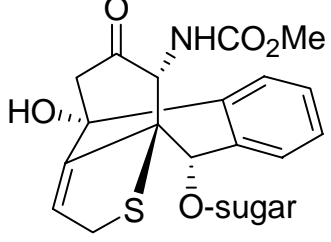

27

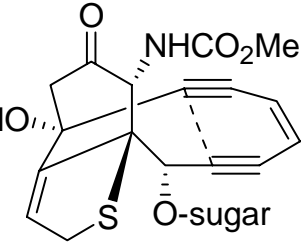

25

Bergman cyclization

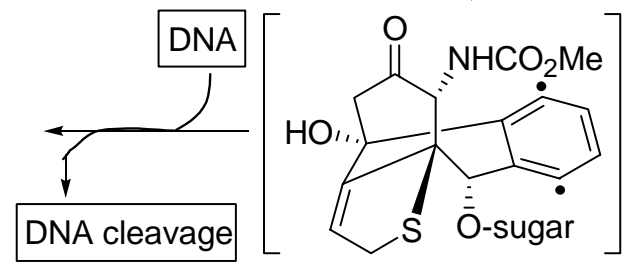

26

Scheme 8. Mechanism of DNA cleavage by calicheamicin.

Although the similarity exists, the prototypical Myers-Saito cyclization reaction differs from the prototypical Bergman cyclization reaction at least in the following two aspects: ${ }^{7}$

1. Myers-Saito cyclization reaction gives rise to a $\sigma-\pi$ biradical while Bergman cyclization reaction produces a $\sigma-\sigma$ biradical.

2. Myers-Saito cyclization reaction is exothermic $(\Delta H \approx-15 \pm 3 \mathrm{kcal} / \mathrm{mol})$, whereas Bergman cyclization reaction is endothermic $(\Delta H \approx 14 \mathrm{kcal} / \mathrm{mol})$.

\section{Schmittel $\left(C^{2}-C^{6}\right)$ Cyclization Reaction}

In 1995, Schmittel et al. discovered a switch from the well-known Myers-Saito cyclization reaction $\left(C^{2}-C^{7}\right.$ cyclization) to $C^{2}-C^{6}$ cyclization reaction (Scheme 9). ${ }^{2 a}$ As above mentioned, the kinetic competition between the $\mathrm{C}^{2}-\mathrm{C}^{6}$ and $\mathrm{C}^{2}-\mathrm{C}^{7}$ cyclization reactions can be most conveniently steered through the proper choice of the substituent at the alkyne terminus: with an aryl group or a bulky group ( $t$-Bu or TMS group) at $\mathrm{C} 7$, the $\mathrm{C}^{2}-\mathrm{C}^{6}$ cyclization reaction is preferred, whereas with a hydrogen or a $n$-alkyl substituent, the $\mathrm{C}^{2}-\mathrm{C}^{7}$ cyclization reaction mode is observed. The effect of the aryl substituent is attributed to its ability to stabilize the alkenyl radical. The sterically demanding group raises the cyclization barrier of the $C^{2}-C^{7}$ cyclization reaction above that of the $C^{2}-C^{6}$ cyclization reaction due to 
steric hindrance.

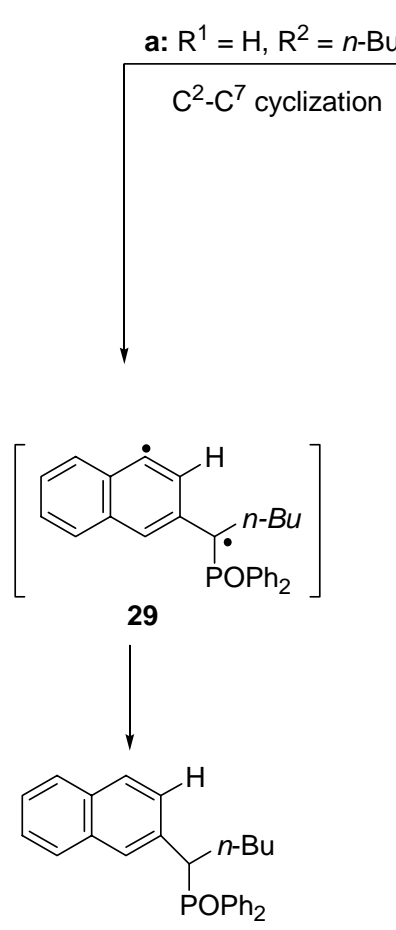

30
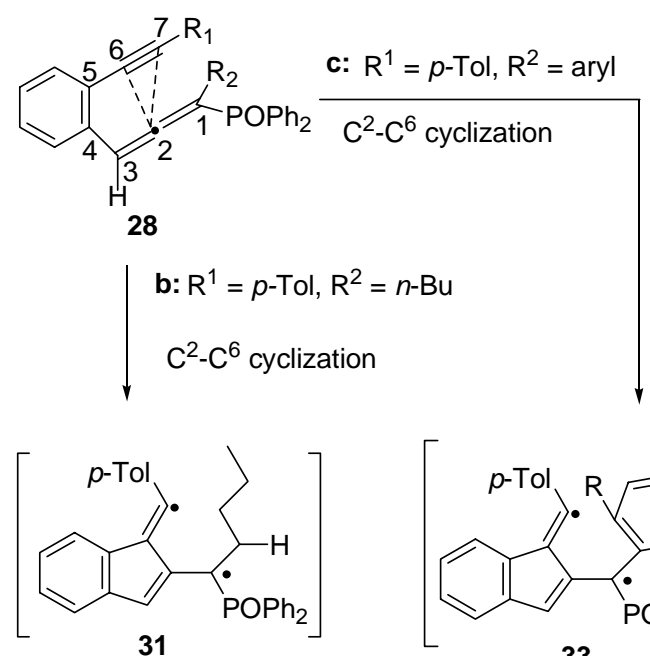

31
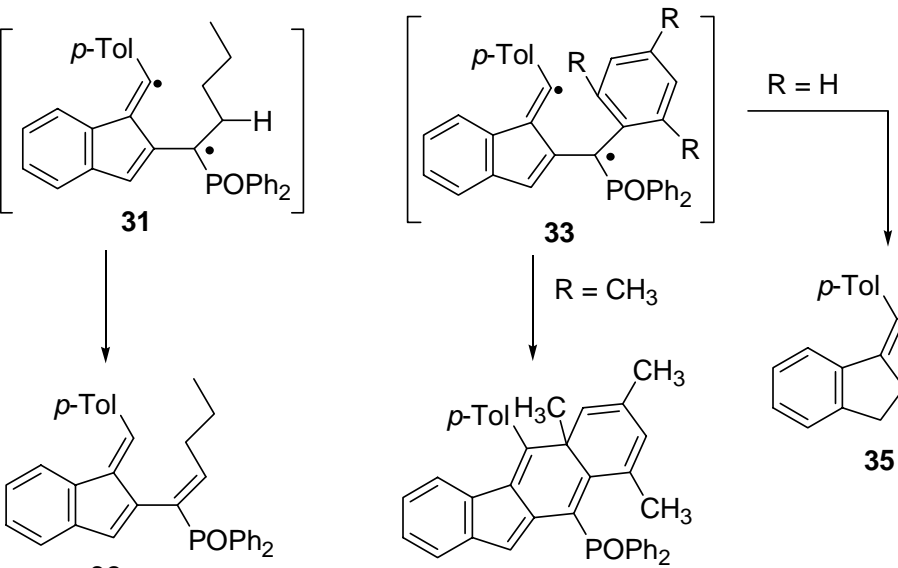

32

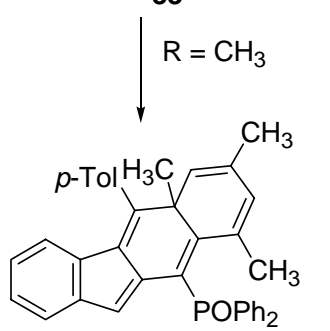

34

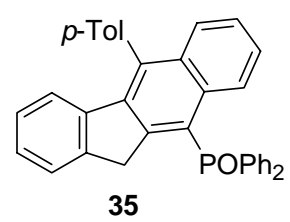

Scheme 9. Switch from $C^{2}-C^{7}$ cyclization to $C^{2}-C^{6}$ cyclization.

Later, our group found similar reaction switch for enyne-ketene imines and enyne-carbodiimides, ${ }^{8 \mathrm{a}, \mathrm{b}}$ Schmittel, Engels and coworkers also reported the similar observation, ${ }^{8 c, d}$ showing that the $\mathrm{C}^{2}-\mathrm{C}^{6}$ cyclization reaction constitutes a general reaction motif (Scheme 10).<smiles>Cc1cc2ccccc2nc1I</smiles>

37<smiles>[Te][Te]</smiles><smiles>[TlH]c1ccc2ccccc2n1</smiles>

38

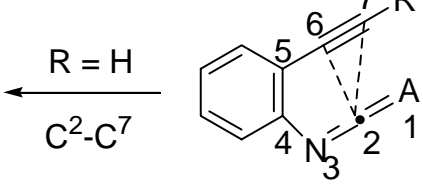

36a: $A=C R^{\prime} R^{\prime \prime}$ 36b: $A=N R^{\prime}$<smiles>[R]c1c2ccccc2[X]c2[nH]c3ccccc3c12</smiles>

41

$$
\underset{\mathrm{C}^{2}-\mathrm{C}^{6}}{\stackrel{\mathrm{R}=\underset{\text { aryl or }}{\text { bulky }}}{\longrightarrow}}
$$

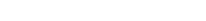

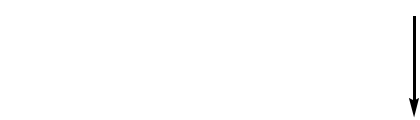<smiles>C1CCCC1</smiles><smiles></smiles>

Scheme 10. Switch from $C^{2}-C^{7}$ cyclization to $C^{2}-C^{6}$ cyclization of hetero enyne-allenes. 
Although most examples in the literature could be reconciled with a concerted ene or a Diels-Alder reaction, mechanistic and theoretical studies are clearly in favor of the fulvene biradical in the course of the $C^{2}-C^{6}$ cyclization reaction based on the following evidence: 1) The $C^{2}-C^{6}$ cyclization reaction does not involve a polar transition state or a polar intermediate. ${ }^{9,2 c}$ 2) From kinetic studies, the reaction is different from Diels-Alder process. ${ }^{2 b}$ For a concerted Diels-Alder reaction mechanism, the activation barrier of the formation 34 would be expected to be much higher than that of formation $\mathbf{3 5}$ because of the steric effect of the bulky mesityl group. Instead these two reactions were found to have very similar activation barriers. 3) Kinetic isotope effect study, ${ }^{10}$ as a powerful diagnostic tool for the distinction between stepwise and concerted mechanism, suggests that the thermal $\mathrm{C}^{2}-\mathrm{C}^{6}$ cyclization reaction of enyne-allenes proceeds through a stepwise biradical mechanism, not a concerted one. 4) The postulated formation of the biradical intermediate is supported by the observation that the enyne-allenes $\mathbf{2 8}$ could induce DNA cleavage as demonstrated by the formation of the open circular DNA. ${ }^{11}$ 5) The convincing evidence for a stepwise biradical mechanism comes from the direct trapping of the fulvene biradical through 1,4-cyclohexadiene (Scheme 11). ${ }^{12}$ When 42 was heated for $18 \mathrm{~h}$ in the neat solvent of 1,4-cyclohexadiene, the benzofulvene derivatives $(Z)-43(7 \%)$ and $(E)-43(4 \%)$ were formed along with the $C^{2}-C^{7}$ cyclization reaction product $44(3 \%)$. Clearly $(Z)-43$ and $(E)-43$ are both derived from the fulvene biradical through hydrogen abstraction.

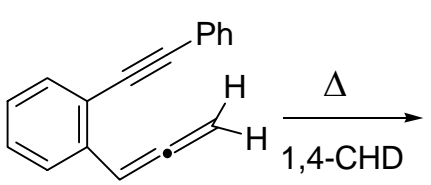

42

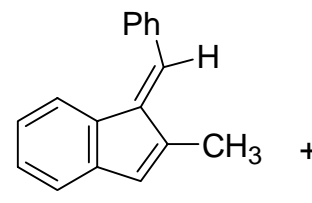

$(Z)-43,7 \%$<smiles>CC1=Cc2ccccc2C1=Cc1ccccc1</smiles>

$(E)-43,4 \%$<smiles>Cc1cc2ccccc2cc1-c1ccccc1</smiles>

$44,3 \%$

Scheme 11. Products from the thermolysis of $\mathbf{4 2}$ in 1,4-cyclohexadiene.

In conclusion, cyclization reaction of benzoenyne-allenes provides an easy access to the naphthalene biradical or the benzofulvene biradical, which is directed by the nature of the substituent at the acetylenic terminus. Myers-Saito cyclization reaction and Schmittel cyclization reaction could be induced either thermally or photochemically. ${ }^{13}$ 


\section{Construction of Polycyclic Ring Systems via Schmittel Cyclization of Enyne-Allenes}

\subsection{Synthesis of Carbocyclic Ring Systems}

Although the current research on the thermal cyclization reaction of enyne-allenes is focused on the theoretical and synthetic studies of model compounds in order to find good anticancer drug candidates, considerable effort has gone into employing the potential of the cycloaromatization reaction for the construction of polycyclic ring systems.

From a synthetic point of view, the Schmittel cyclization reaction has become a valuable synthetic tool for the construction of carbocyclic ${ }^{14}$ and heterocyclic ${ }^{8,15}$ ring systems, since the biradical intermediate could undergo a follow-up reaction to give formal Diels-Alder adducts that provides a convenient access to polycyclic aromatic systems.

Hai-Ren Zhang of Dr. Wang's group developed an approach to the chlorinated enyne-allene, which could proceed via a cascade reactions involving a Schmittel cyclization reaction and a subsequent formal Diels-Alder reaction to afford novel polycyclic ring systems. ${ }^{16}$ This pathway was successfully adopted for the synthesis of a $\mathrm{C}_{44} \mathrm{H}_{26}$ hydrocarbon having a carbon framework represented on the surface of $\mathrm{C}_{60}$ (Scheme 12). ${ }^{16 \mathrm{a}}$

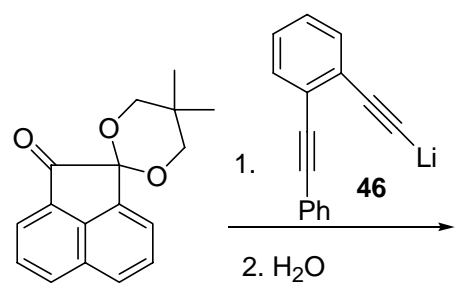

45

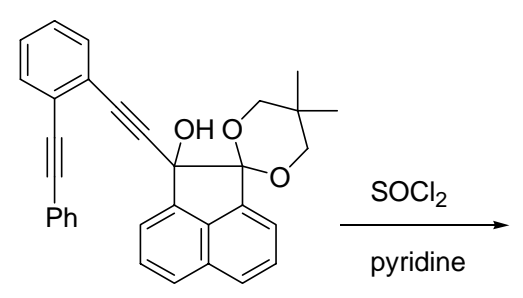

47, $77 \%$

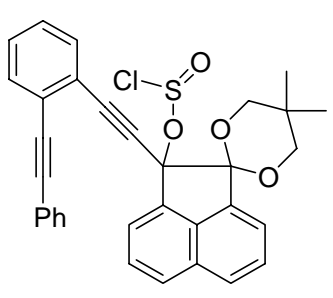

48

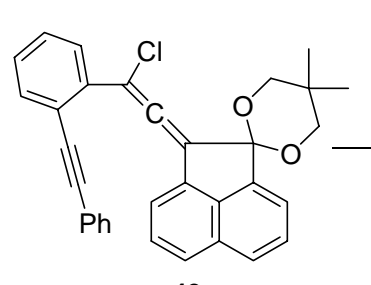

49

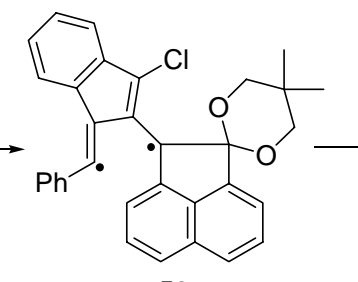

50

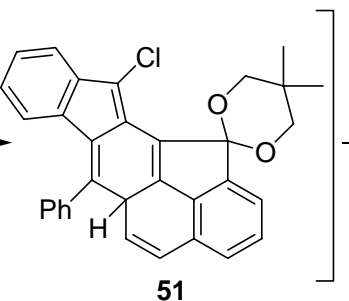

51

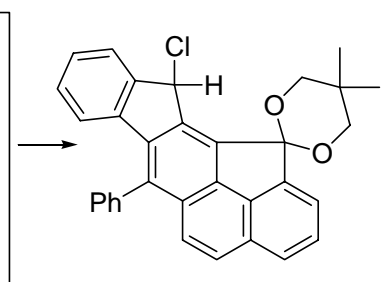

52

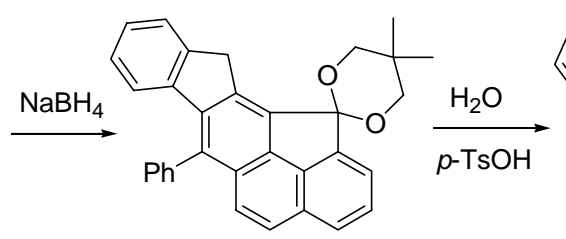

53, $51 \%$

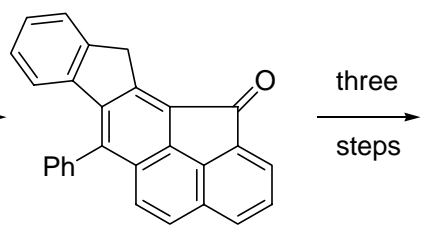

54, 93\%

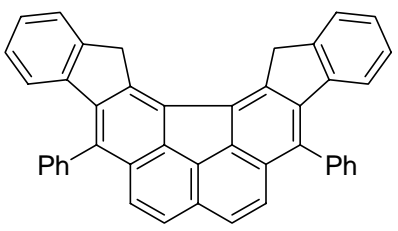

55, 39\%

Scheme 12. Synthesis of a $\mathrm{C}_{44} \mathrm{H}_{26}$ hydrocarbon via the Schmittel cyclization reaction. 
A new synthetic pathway to twisted 4,5-diarylphenanthrenes 60 via Schmittel cyclization reaction of benzannulated enyne-allenes was developed by Dr. Hongbin Li of Dr. Wang's group (Scheme 13). ${ }^{17}$

\section{1. $n$-BuLi}

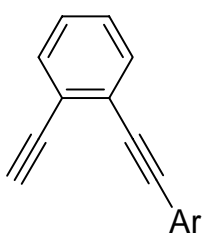

2.

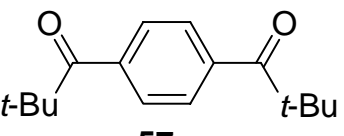

57

\section{3. $\mathrm{H}_{2} \mathrm{O}$}

56a: $\mathrm{Ar}=\mathrm{Ph}$

56b: $\mathrm{Ar}=4$-biphenylyl

56c: $\mathrm{Ar}=3,5$-dimethylphenyl

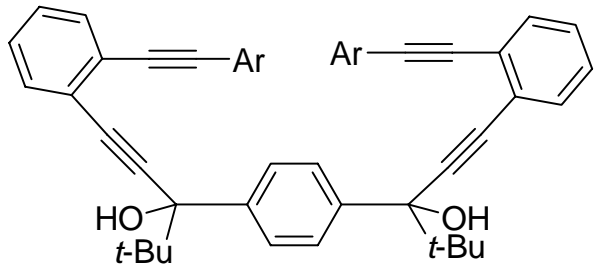

58a: $92 \%$

58b: $92 \%$

58c: $98 \%$

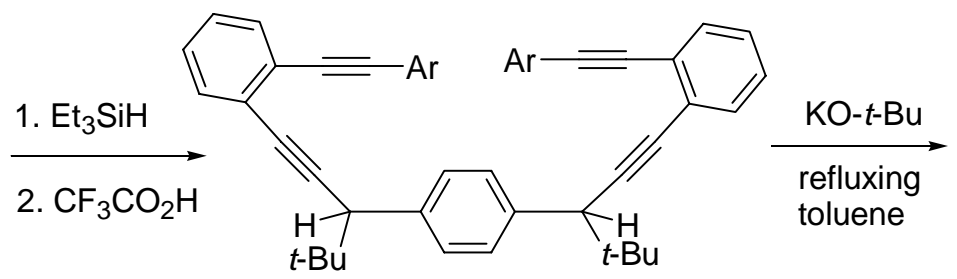

59a: $93 \%$

59b: $99 \%$

59c: $96 \%$

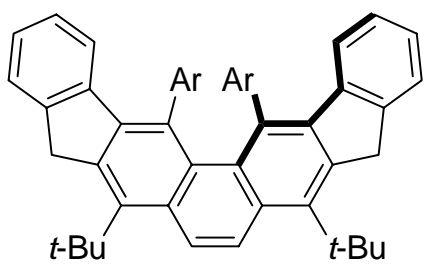

60a: $44 \%$

60b: $46 \%$

60c: $40 \%$

Scheme 13. Synthesis of twisted 4,5-diarylphenanthrenes.

Moreover, the Schmittel cyclization reaction was employed as a key step in the construction of the benzo[b]fluorine core of several metabolites structurally related to the kinamycin family of antibiotics (Scheme 14). ${ }^{14 a}$<smiles>CCN(C)CCO</smiles>

61

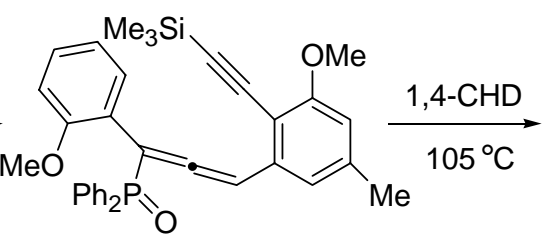

62, $93 \%$<smiles>COC1=C2C(C)=C(Cc3cc(C)cc(OC)c32)P(=O)(c2ccccc2)c2c(OC)cccc21</smiles>

$63,38 \%$

Scheme 14. Synthesis of the benzo[b]fluorine core of kinamycins.

\subsection{Synthesis of Heterocyclic Ring Systems}

The synthetic applications of the biradical intermediates could be further extended to the systems of enyne-ketenimines and enyne-carbodiimides as described in Scheme 10. Dr. Wang group successfully adopted this strategy to synthesize several novel hetereocyclic ring systems structurally related to the naturally occurring ellipticine and its derivatives 
(Scheme 15). ${ }^{18}$

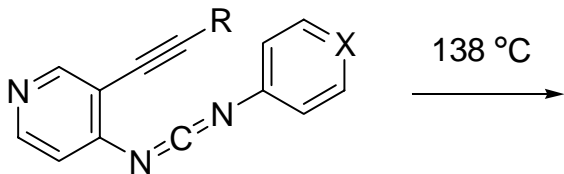

64a: $\mathrm{X}=\mathrm{CH}$

64b: $X=N$<smiles>[R]c1c2c[X]ccc2nc2[nH]c3ccncc3c12</smiles>

65a: $\mathrm{X}=\mathrm{CH}$

65b: $X=N$

Scheme 15. Synthesis of novel heteroaromatics structurally related to ellipticine via thermolysis of pyridannulated enyne-carbodiimides.

\section{Literature Survey on the Synthetic Methodologies for the Preparation of Enyne-Allenes}

Due to wide synthetic applications of the thermal cyclization reactions of enyne-allenes, a variety of synthetic methods have been developed for the preparation of enyne-allenes with diverse structural features. ${ }^{19}$

The enyne-allene 4 could be easily synthesized from the enediynyl propargylic diazene 67 through a spontaneous sigmatropic rearrangement (Scheme 16). ${ }^{1 \mathrm{a}, \mathrm{b}, \mathrm{c}, 20}$

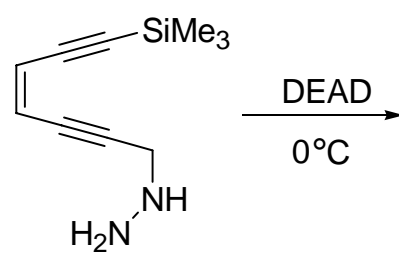

66

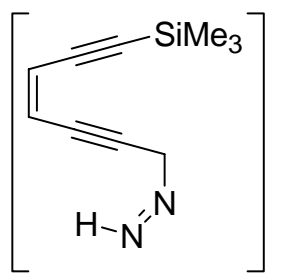

67

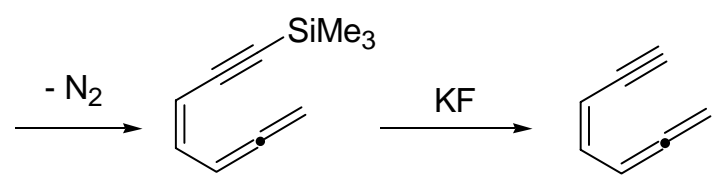

$68,62 \%$
4, 60\%

Scheme 16. Synthesis of enyne-allene 4 via a sigmatropic rearrangement.

Transition-metal catalyzed coupling reactions have been employed for the synthesis of a variety of enyne-allenes. For example, thermolabile enyne-allene ester $\mathbf{7 2}$ could be prepared by a Pd-catalyzed cross-coupling reaction between arylzinc halide 69a or arylboronic acid $\mathbf{6 9 b}$ and 2-haloallene carboxylates 70 under mild conditions (Scheme 17). ${ }^{21}$

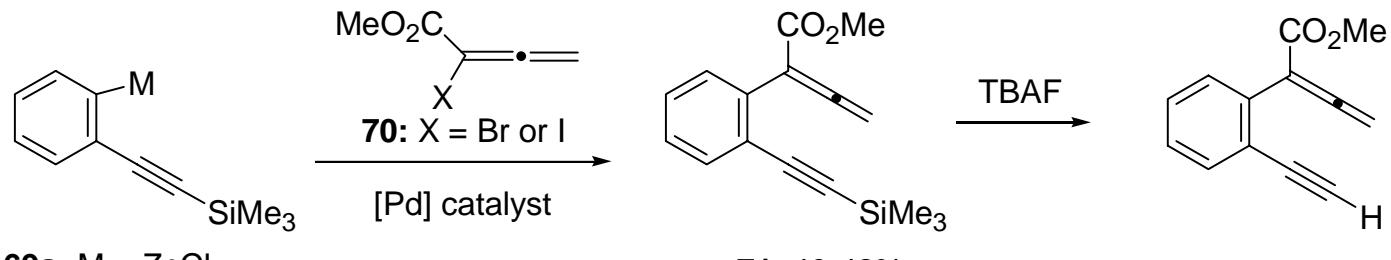

69a: $\mathrm{M}=\mathrm{ZnCl}$

71, $40-42 \%$

$72,67 \%$

Scheme 17. Synthesis of benzannulated enyne-allene 72 via Pd-catalyzed coupling. 
Enyne-allenes could also be synthesized through the Horner-Wittig and related reactions. An example was reported by Finn et al. by using the metallated phosphorus methylide reagent $\mathbf{7 4}$, which could undergo double olefination with aldehydes $\mathbf{7 3}$ to give enyne-allenes 77 as outlined in Scheme $18 .^{22}$

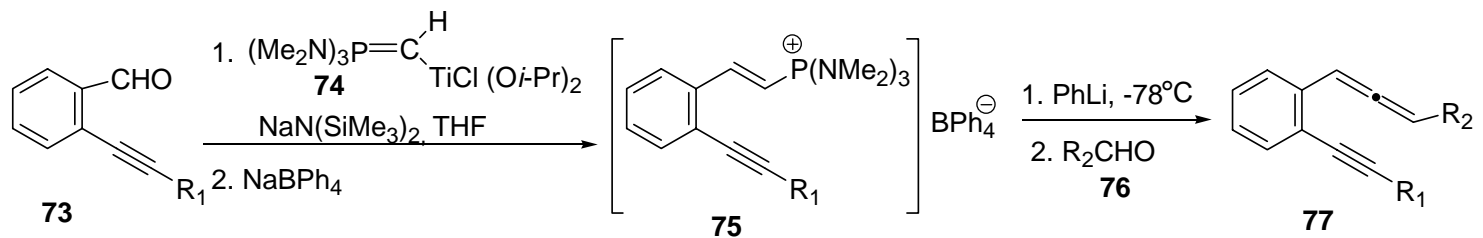

Scheme 18. Synthesis of benzannulated enyne-allenes 77 via titanium-substituted ylides.

The prototropic rearrangement of enediynes affords a simple and direct synthetic pathway to enyne-allenes. For example, enyne-allene $\mathbf{7 9}$ could easily obtained from $\mathbf{7 8}$ through a prototropic rearrangement under basic conditions (Scheme 19). ${ }^{23}$

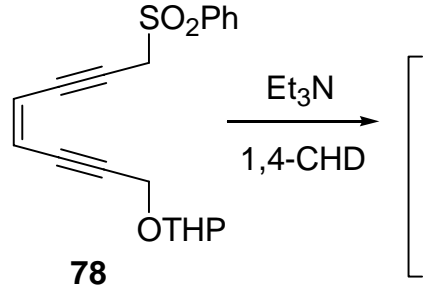

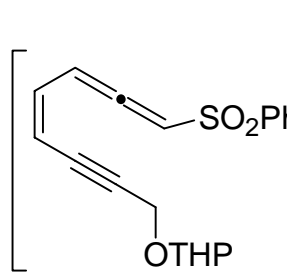

79

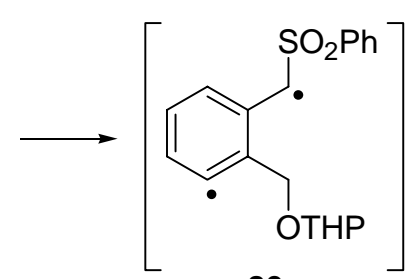

80<smiles>O=S(=O)(O)Cc1ccccc1C[PH-]</smiles>

$81,45 \%$

Scheme 19. Synthesis of enyne-allene via prototropic rearrangement of enediynyl sulfone.

The [2,3]-sigmatropic rearrangement of enediynyl propargylic alcohols is widely used for the preparation of enyne-allenes. This approach was first reported by Sevin et al. in $1967^{24}$ and later was adopted by Saito, ${ }^{1 \text { d.e }}$ Nicolaou, ${ }^{25}$ Grissom $^{26}$ and Schmittel $^{2 b, d}$ for the synthesis of a variety of allenyl phosphonates or phosphine oxides. For instance, Nicolaou et al. reported that phosphine oxides $\mathbf{8 4}$ could be obtained from propargylic alcohols $\mathbf{8 2}$ via a $[2,3]$-sigmatropic rearrangement induced by chlorodiphenylphosphine (Scheme 20).<smiles>[R2]C#CC([R1])=C([R1])C(O)C#CC[R5]</smiles>

82

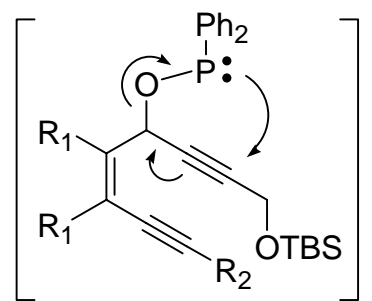

83

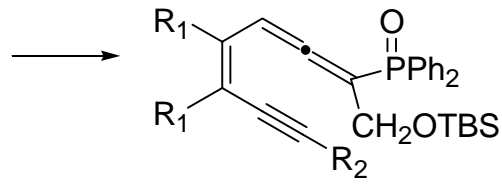

84

Scheme 20. Synthesis of enyne-allenes via a [2,3]-sigmatropic rearrangement. 
The synthetic strategy involving the use of a [3,3]-sigmatropic rearrangement of propargylic vinyl ethers for the preparation of enyne-allenes has also been reported. Grissom et al. discovered that a [3,3]-sigmatropic rearrangement of $\mathbf{8 5}$ was promoted by either thermolysis $\left(150{ }^{\circ} \mathrm{C}\right)$ or a Lewis-acid catalyst $\mathrm{AgBF}_{4}$ at room temperature to afford enyne-allene 87 (Scheme 21). ${ }^{26}$

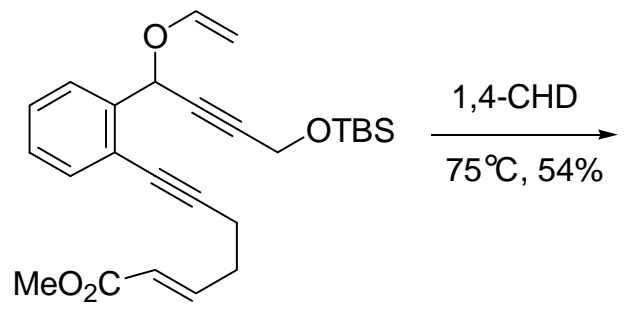

85<smiles>CC(=O)CC1CCc2c(C(CC=O)CO[Sb])cc3ccccc3c21</smiles>

86

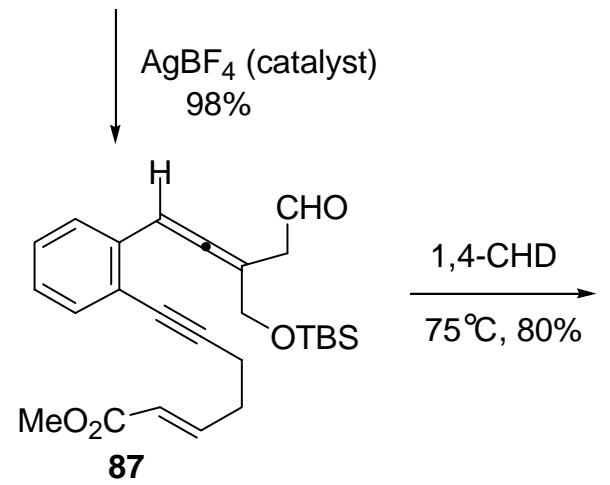<smiles>CC=CCCc1cc2ccccc2cc1[C@@H](CC=O)COC(C)=O</smiles>

88

Scheme 21. Synthesis of enyne-allene 87 via a [3,3]-sigmatropic rearrangement.

Rearrangement of propargylic derivatives could also afford corresponding enyne-allenes. Schmittel et al. ${ }^{11 \mathrm{~b}}$ reported that benzannulated enyne-allenes $\mathbf{9 1}$ and $\mathbf{9 2}$ were prepared from the propargylic acetates $\mathbf{9 0}$ by cuprate addition or by Pd-catalyzed addition of arylzinc chloride, respectively (Scheme 22).

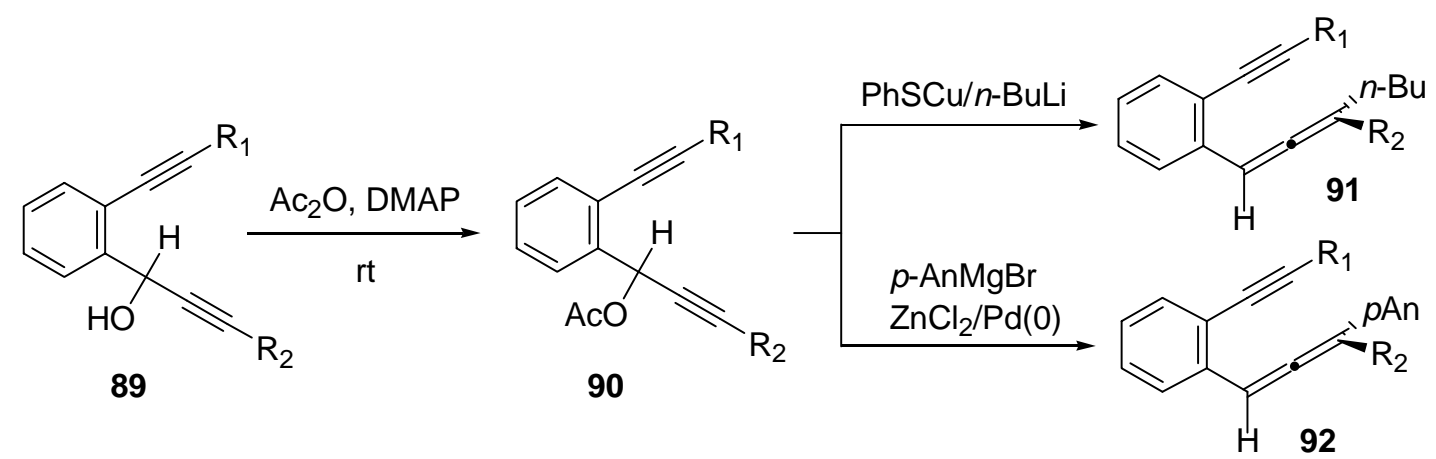

Scheme 22. Synthesis of enyne-allenes via rearrangement of propargylic acetates. 
Cunico et al. developed a method for in situ formation of enyne-allene 95 based on a facile elimination and trimethylsilyl (TMS) group migration within the propargylic framework of 94 (Scheme 23). ${ }^{27}$<smiles>[Y5]C([OH2+])([AsH3])C#CC(O)c1ccccc1C#C</smiles>

93

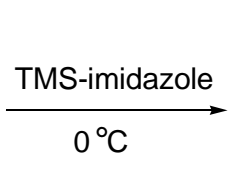

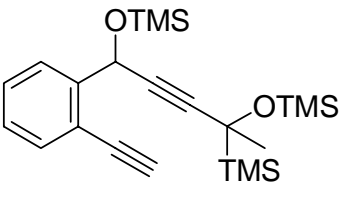

94, $87 \%$
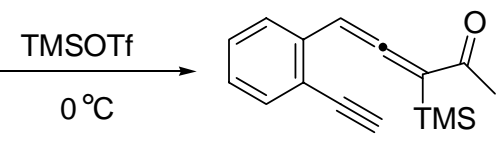

95, $91 \%$

Scheme 23. Synthesis of enyne-allene 95 with keto substituent.

The strategy of a nucleophilic attack on the acetylenic ketone functionality to form benzannulated enyne-allenes was adopted by Lipton et al. for the preparation of the oxygen-substituted enyne-allenes $9{ }^{28}{ }^{28}$ Treatment of acetylenic ketones 96 with cuprate followed by trapping the resultant enolates with acetic anhydride afforded enyne-allenes $\mathbf{9 7}$ in good yield (Scheme 24).<smiles>[R]C#Cc1ccccc1C(=O)C#CC(C)(C)C</smiles>

96, $\mathrm{R}=\mathrm{Me}_{3} \mathrm{Si}, t-\mathrm{Bu}$, $\mathrm{Ph}$, or $\mathrm{Bu}$

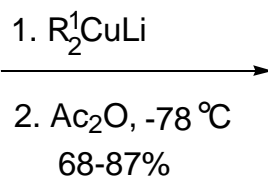
$68-87 \%$

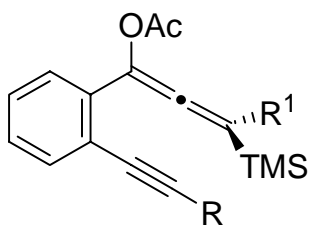

97, $\mathrm{R}^{1}=\mathrm{CH}_{3}, \mathrm{CD}_{3}, \mathrm{Ph}$

Scheme 24. Synthesis of enyne-allenes 97 via conjugate addition of dialkylcuprates.

Dr. Wang group reported several convenient approaches for the synthesis of enyne-allenes. An example is outlined in Scheme 25. ${ }^{14 b, 29}$ Condensation between allenic aldehydes 99 and [ $\gamma$-(trialkylsilyl)allenyl]borane 98 furnished the corresponding $\beta$-silyl alcohols 100, which on subsequent elimination of the hydroxyl and the silyl groups produced enyne-allenes 101a $(Z: E=96: 4)$ and 101b $(Z: E=99: 1) .{ }^{29}$

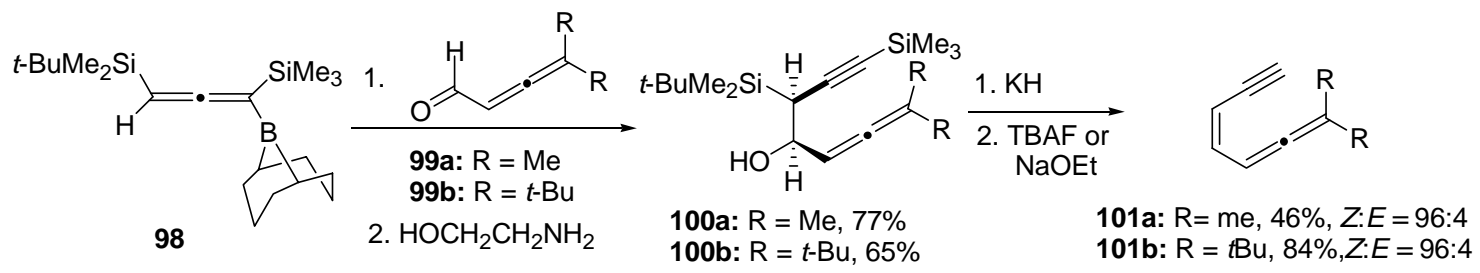

Scheme 25. Synthesis of enyne-allenes 101 from condensation between

allenic aldehydes and [ $\gamma$-(trialkylsilyl)allenyl]borane. 


\section{Chapter II}

\section{Synthesis of Diindeno-Fused $4 \mathrm{H}$-Cyclopenta[def]phenanthrene via Benzannulated Enediynyl Propargylic Alcohol}

\section{Introduction}

Our research group reported an efficient approach to produce chlorinated benzoenyne-allene 105 through $\mathrm{S}_{\mathrm{N}} \mathrm{i}$ ' reaction promoted by treatment of benzannulated enediynyl propargylic alcohol 103 with thionyl chloride. ${ }^{30}$ A subsequent Schmittel $C^{2}-C^{6}$ cyclization generated the biradical 106, which in turn underwent an intramolecular radical-radical coupling to give the formal Diels-Alder adduct 107. Tautomerization followed by hydrolysis then afforded 109 and minor [2+2] adduct 110. The efficiency of the reaction sequence provides many opportunities for the assembly of novel aromatic structures.
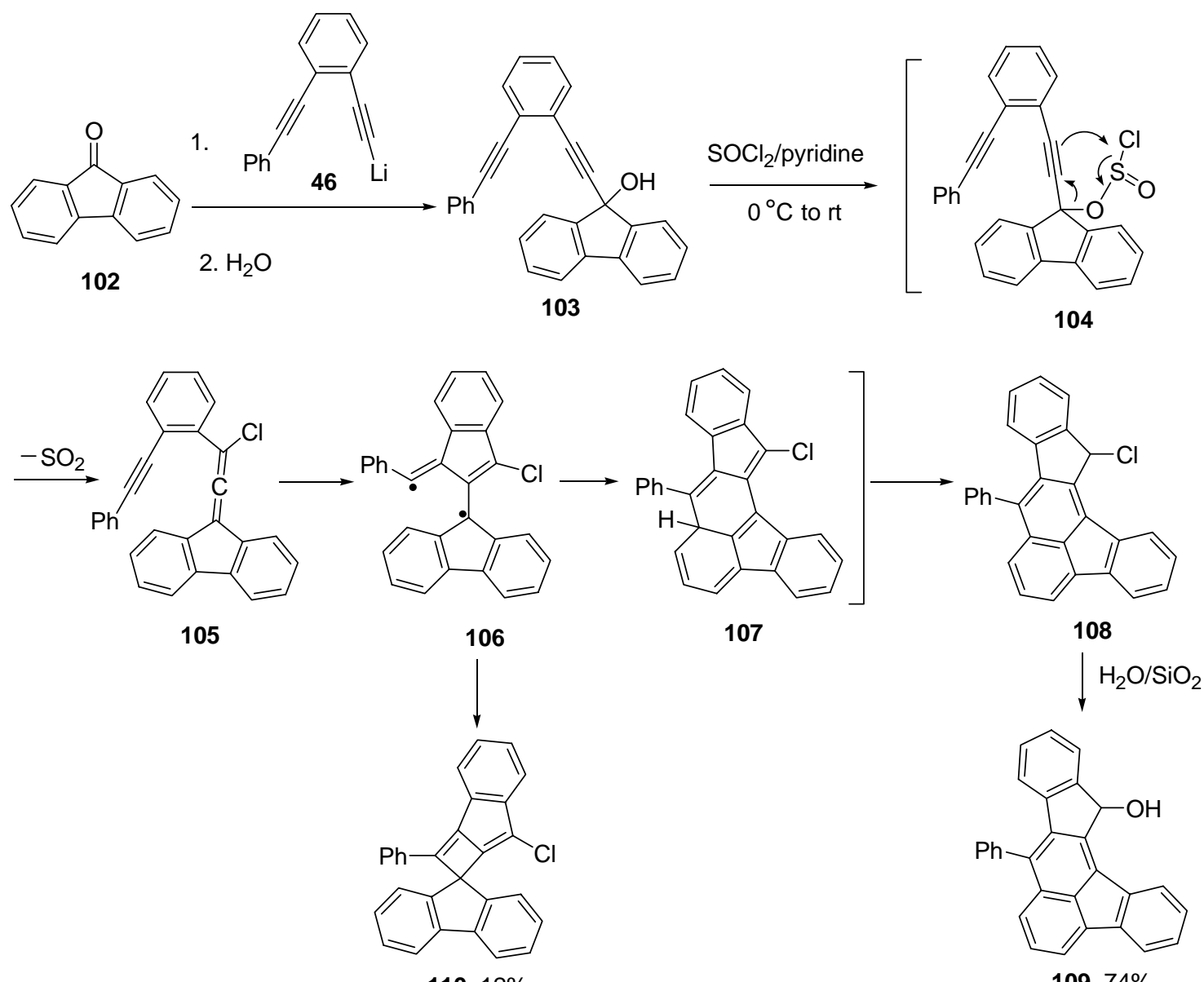

$110,12 \%$

$109,74 \%$

Scheme 26. Schmittel cyclization of chlorinated benzoenyne-allene. 


\section{Research Objective}

Derivatives of $4 H$-cyclopenta[def]phenanthrene could be used as precursors for the synthesis of polycyclic aromatic hydrocarbons with carbon frameworks represented on the surface of $\mathrm{C}_{60}$. For example, 3-carbomethoxy-4H-cyclopenta[def]phenanthrene was used in the first synthesis of corannulene, a bow-shaped $\mathrm{C}_{20} \mathrm{H}_{10}$ aromatic hydrocarbon. ${ }^{31}$ Based on the simple and efficient route to polycyclic aromatic compounds via chlorinated benzoenyne-allene, we envisioned that by replacing 9-fluorenone with 2,2-dimethylindene-1,3-dione, the synthetic sequence outlined in Scheme 26 could lead to diindeno-fused $4 H$-cyclopenta[def]phenanthrene.

\section{Literature Survey for the Synthesis of $4 \mathrm{H}$-Cyclopenta[def]phenanthrene}

Several synthetic methods have been reported for the synthesis of $4 H$-cyclopenta[def]phenanthrenes. ${ }^{32,31}$ The Friedel-Crafts cyclization of derivatives of phenanthrenes or acenaphthylenes was a key step for most approaches. We have also synthesized several derivatives of $4 H$-cyclopenta[def]phenanthren-4-one via the Schmittel cyclization of chlorinated benzoenyne-allenes. ${ }^{33}$ My contribution in this project is summarized in the following section.

\section{Results and Discussion}

The benzannulated enediynyl propargylic alcohols are useful precursors of the corresponding enyne-allenes, which have found applications in the synthesis of polycyclic aromatic compounds. $^{2 b, c, 16,17}$ We have successfully employed this synthetic pathway for efficient transformation of 1,3-indandione $\mathbf{1 1 1}^{34}$ to the diindeno-fused 4H-cyclopenta[def]phenanthrene 118 (Scheme27).

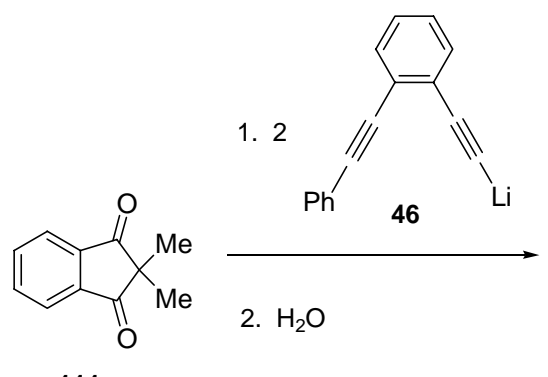

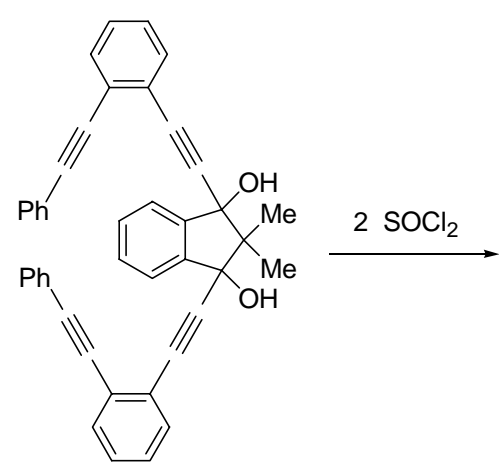

112a: trans-diol, $51 \%$ 112b: cis-diol, $9 \%$

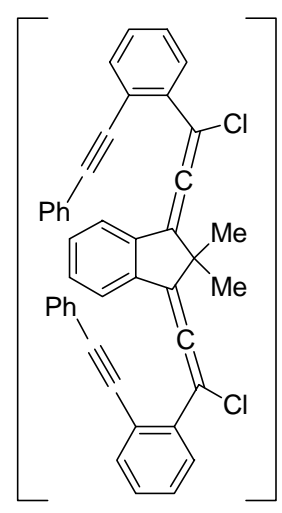

113 


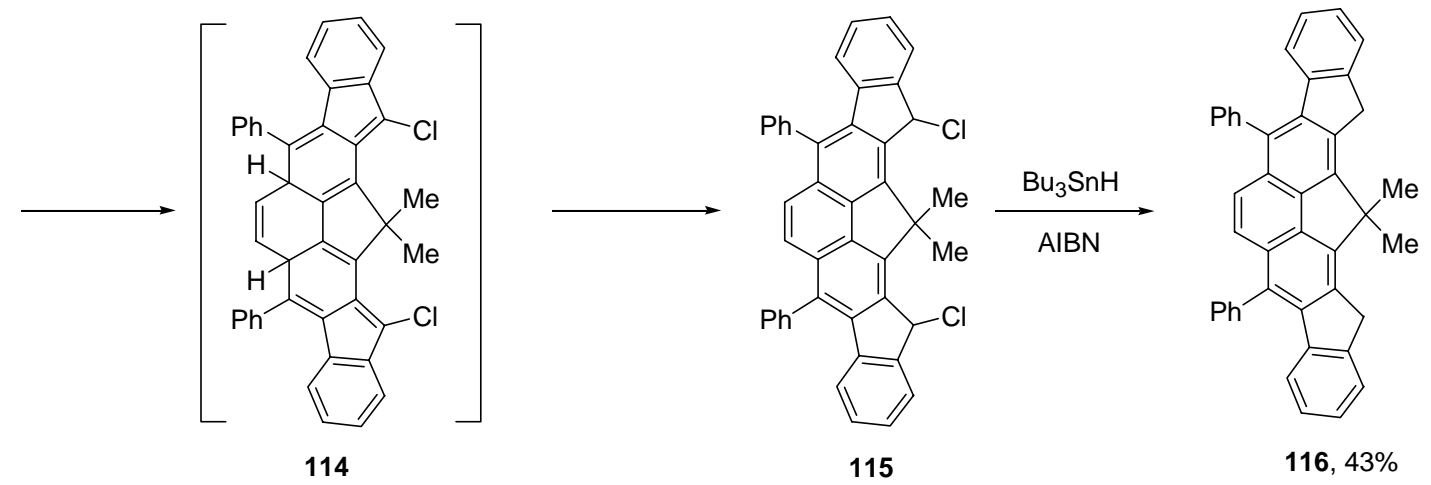

Scheme 27. Synthesis of $4 H$-cyclopenta[def]phenanthrene.

Condensation between 111 and 2 equiv of $\mathbf{4 6}$ led to propargylic diols $\mathbf{1 1 2}$ as a mixture of the trans and cis isomers. Treatment of trans-112a with thionyl chloride then promoted a cascade sequence of reactions involving initially two $\mathrm{S}_{\mathrm{N}} \mathrm{i}^{\prime}$ reactions to produce in situ the benzannulated chloroenyne-allene $\mathbf{1 1 3}$ as described previously. ${ }^{16 a, 17}$ Two subsequent formal Diels-Alder reactions, presumably with each involving a Schmittel cyclization reaction to form the corresponding biradical $^{2 b . c}$ followed by an intramolecular radical-radical coupling reaction, then gave 114, which in turn underwent two prototropic rearrangements to furnish the diindeno-fused $4 H$-cyclopenta[def]phenanthrene derivative 115. It was operationally convenient to reduce the crude product of $\mathbf{1 1 5}$ without further purification with tributyltin hydride to furnish 116 in $43 \%$ overall yield from trans-112a.

It is worth noting that four new rings were formed in one step under mild conditions, which demonstrates the efficiency of the approach for the construction of polycyclic aromatic structures.

Because the relative reaction rates of the steps of the cascade sequence have not been determined, it is also possible that the first unit of the benzannulated enediynyl propargylic alcohol moiety could undergo a formal Diel-Alder reaction and a prototropic rearrangement before the second unit would begin its cyclization sequence.

\section{Conclusions}

The success in using diols $\mathbf{1 1 2}$ for two cascade reaction sequences in a single operation further demonstrates the versatility of this synthetic pathway for the construction of novel polycyclic aromatic structures. The diindeno-fused $4 H$-cyclopenta[def]phenanthrene 116 has a 41-carbon framework, 38 carbons on the aromatic rings and three carbons on the 
three five-membered rings, that is represented on the surface of $\mathrm{C}_{60}$. 


\section{Chapter III}

\section{Helicenes}

\section{Introduction}

Helicenes are a well-known representative of polycyclic aromatic compounds with a structure characterized by a series of ortho-condensed aromatic rings (Figure 2). ${ }^{35}$ When the number of annulated arenas increases, the system can not be planar and then adopts a helical structure to release the steric congestion. Due to the nonplanar structures, helicenes are inherently chiral.

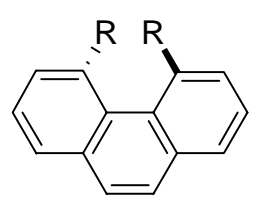

117, $\mathrm{R}=\mathrm{Me}, \mathrm{Ph}$

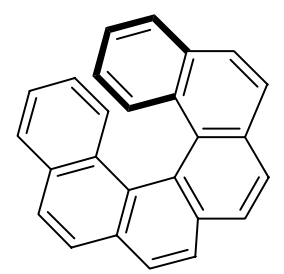

118, [6] Helicene

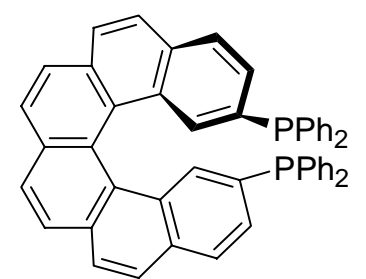

119, Helical-chiral Ligand

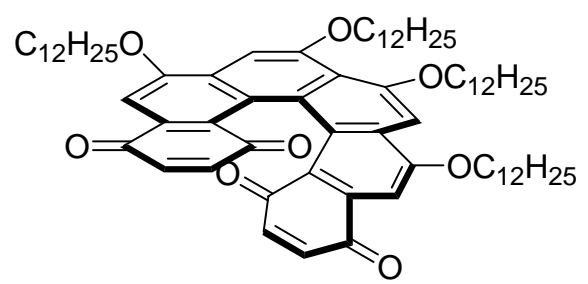

120, Helicenequinone

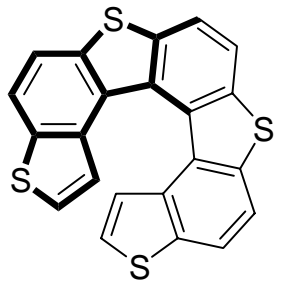

121, Hetero[7]helicene

Figure 2. Examples of helicenes.

\section{Potential Applications of Helicenes}

For many years, helicenes were studied just for an academic curiosity. More recently, with the further studies of this kind of compound, more and more potential applications have been found out. Due to their extraordinary optical and electronic properties, helicenes could be potentially used as optical materials, ${ }^{36}$ asymmetric catalysts, ${ }^{37}$ asymmetric molecular recognition ${ }^{38}$ and molecular devices. ${ }^{39}$

It is worth noting that enantiopure helical hydrocarbons, [6]helicene 118 and [5]helicene 123 without any heteroatoms, could act as a chiral inducer in highly enantioselective synthesis of pyrimidyl alkanol 124 by addition of diisopropylzinc to 2-(2-tert-butylethynyl)pyrimidine-5-carbaldehyde (122) (Scheme 28). ${ }^{37 \mathrm{~g}}$ When aldehyde 122 
$(0.05 \mathrm{mmol})$ was treated with $i-\operatorname{Pr}_{2} \mathrm{Zn}(0.15 \mathrm{mmol})$ in the presence of $(P)-(+)-[6]$ helicene 118a $(6 \mathrm{~mol} \%,>99.5 \%$ ee $)$ at $0{ }^{\circ} \mathrm{C}$ in toluene, $(S)$-5-pyrimidyl alkanol $(S)$-124a was obtained (95\% ee, 95\% yield). On the other hand, in the presence of $(M)-\mathbf{1 1 8 b}(7 \mathrm{~mol} \%)$, the enantiomer $(R)$-124b was formed $(93 \%$ ee, $93 \%$ yield). The same observation of the asymmetric induction was also found for [5]helicene 123. The mechanism of asymmetric induction by the helical hydrocarbons was postulated to involve coordination of the chiral helicenes with the carbonyl moiety and the pyrimidine ring of the aldehyde 122, so that the $R e$ and $S i$ faces of the carbonyl group may be differentiated. When $i-\operatorname{Pr}_{2} \mathrm{Zn}$ is added, a nonracemic zinc alkoxide of the corresponding alkanol is formed.

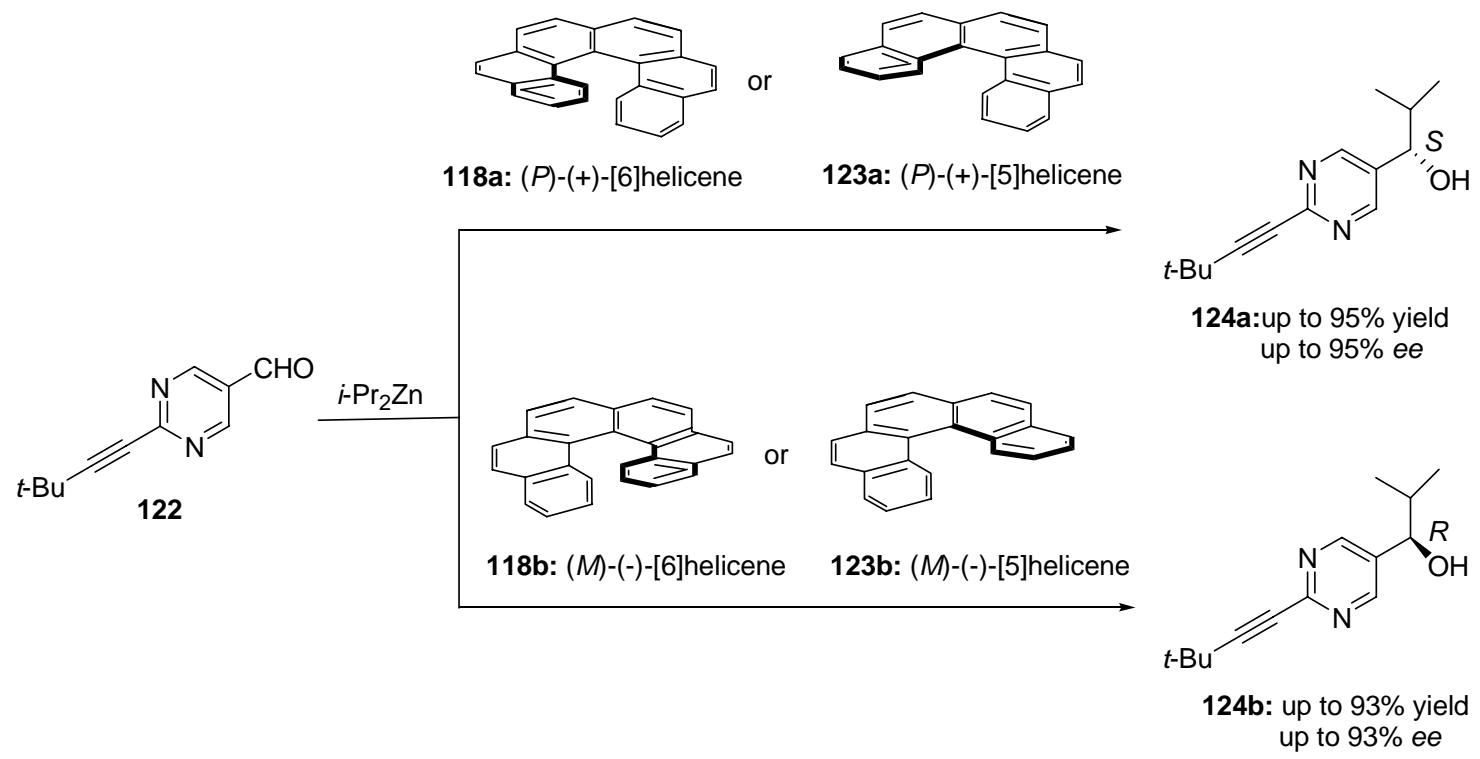

Scheme 28. Asymmetric induction by helical hydrocarbons.

Because helicenes have such wide potential applications, there is a need for efficient and enantioselective approaches to the synthesis of this kind of compounds.

\section{Literature Survey for the Synthesis of Helicenes}

\section{1. Approaches for Racemic Helicenes}

[6]Helicene was synthesized by Newman through Friedel-Crafts acylations and resolved by formation of a charge-transfer complex in $1955 .{ }^{40}$ His brilliant work in this field opened the door for the study of this fascinating class of helical molecules.

The classical method for the synthesis of helicenes is based on the photocyclization of stilbene-type precursors (Scheme 29). ${ }^{41}$ Although useful, due to poor 
regioselectivity in the photocyclization step, this method produced a mixture of isomers in some cases. This traditional approach also suffered from other fundamental drawbacks, such as highly dilute solution and low functional group tolerance.

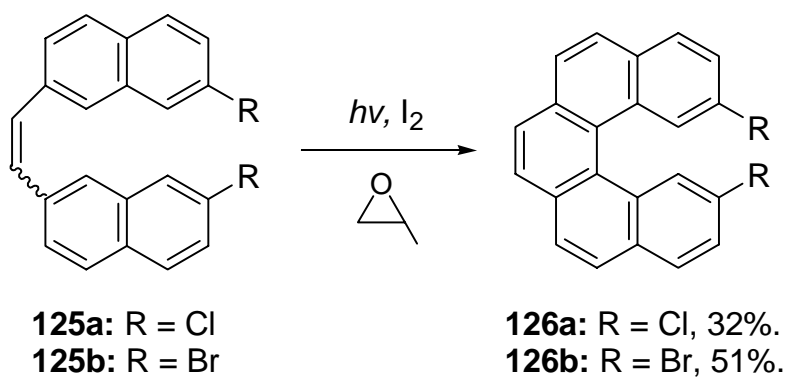

Scheme 29. Synthesis of helicenes via photocyclization of stilbene-type precursors.

The first efficient non-photochemical route for the synthesis of racemic helicenes 129 was developed by Katz and coworkers through double Diels-Alder cycloaddition reactions ${ }^{42}$ between divinylarene 127 and 1,4-benzoquinone 128 (Scheme 30).

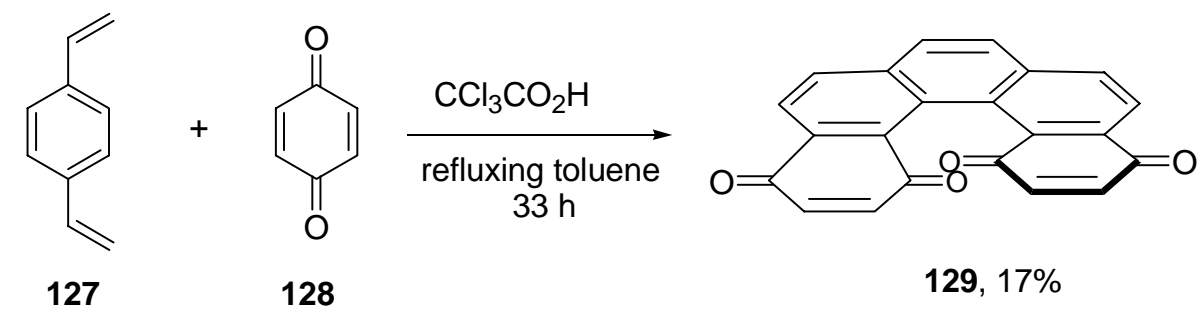

Scheme 30. Katz's simple non-photochemical route to helicene quinones.

An approach for the synthesis of [7] helicene was reported by Gingras et al. in 1998 by using carbenoid coupling of aromatic bis(bromomethyl) moieties(Scheme 31) ${ }^{43}$ or McMurry coupling of a dialdehyde. The carbenoid coupling could provide [7]helicene in $75 \%$ yield on a gram-scale.

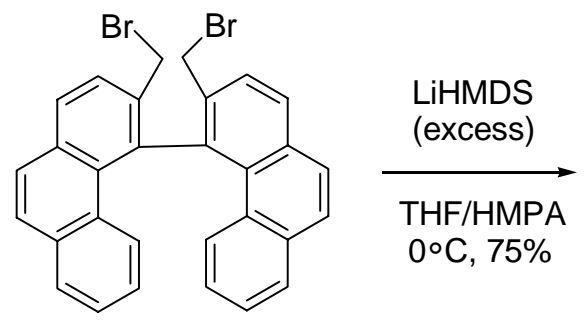

130

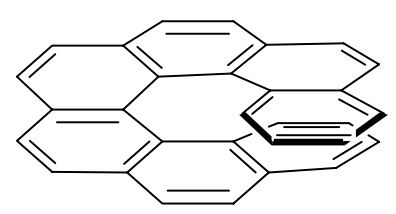

131

Scheme 31. Gingras's approach to [7] helicene by “carbenoid coupling” strategy.

A new route to [5]helicenes was developed by Harrowven et al, involving a tin-mediated, non-reducing tandem radical cyclization of $(Z, Z)$-1,4-bis(2-iodostyryl)benzene 
derivatives as a key step. ${ }^{44}$ This short protocol could provide different substituted [5]helicenes with yields ranging from 35 to $58 \%$. An example is outlined in Scheme 32.

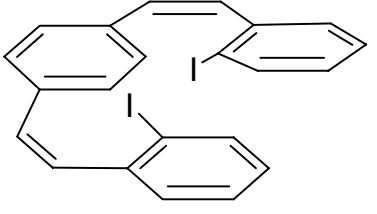

132

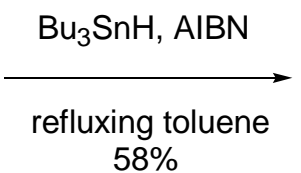

$58 \%$

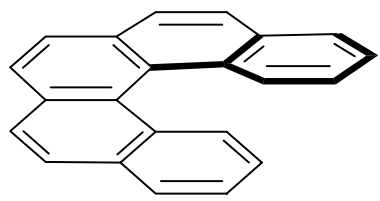

133

Scheme 32. Synthesis of [5]helicene by iterative radical cyclization.

Transition metal-catalyzed cycloisomerization reactions have been employed for the synthesis of a variety of helicenes. This novel strategy was adopted by Stará et al. ${ }^{45}$ through nickel( $(0)$-catalyzed [2+2+2] cycloisomerization of cis,cis-dienetriyne to afford [6]helicene in $61 \%$ yield in one operation with the formation of three new rings. The new paradigm provided an efficient non-photochemical method for the synthesis of different substituted [5], [6] and [7]helicenes with yields ranging from 60 to $83 \%$.

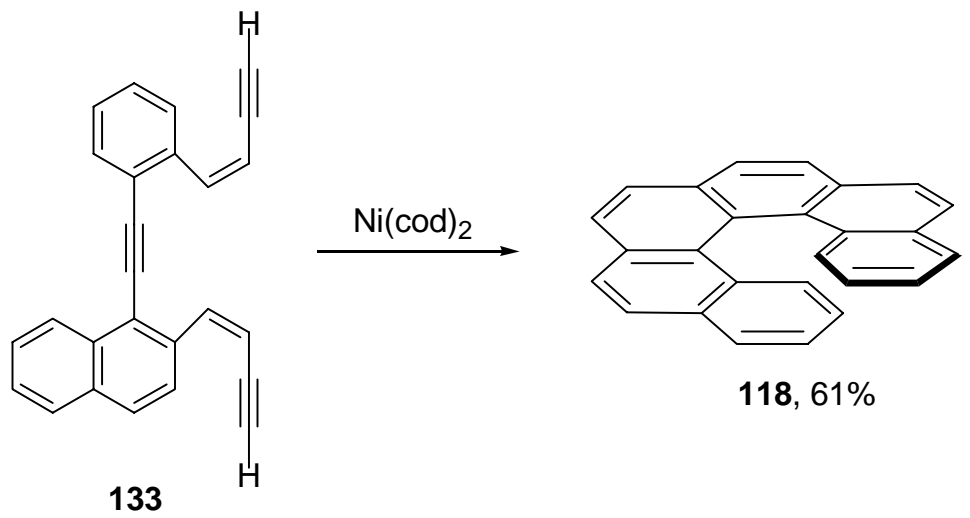

Scheme 33. Synthesis of [6]helicene by nickel(0)-catalyzed [2+2+2] cycloisomerization.

Vollhardt and coworkers reported another transition metal-catalyzed approach to angular $[n]$ phenylenes by cobalt-catalyzed $[2+2+2]$ cycloisomerization (Scheme 34$){ }^{46}$ [7]Phenylene 135, the first helical phenylene, could be obtained through cobalt-catalyzed double cycloisomerization of hexayne 134 in $8 \%$ yield in one step with the formation of six new rings. A more efficient approach to [7]phenylene 135 involved cobalt-catalyzed triple cycloisomerization of nonayne 136 in low yield (2\%), but forming nine rings in one step. 


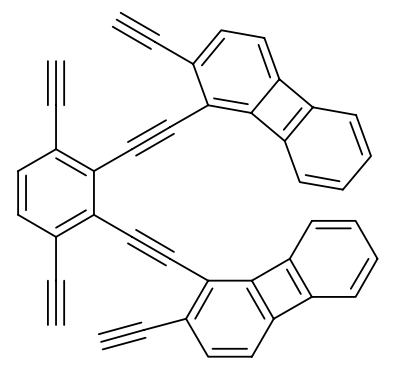

134

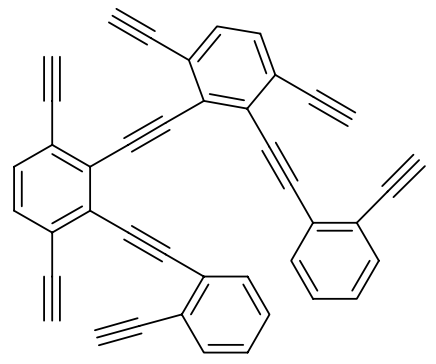

136

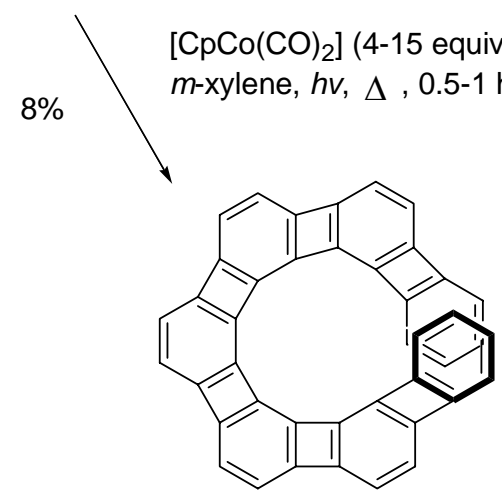

135

Scheme 34. Vollhardt's approach to [7] phenylene by cobalt-catalyzed double and triple cycloisomerizations.

\subsection{Asymmetric Approaches for Helicenes}

Despite remarkable progress in the synthetic methodology development of helicenes, there is still a major challenge to develop efficient asymmetric approaches to the helical compounds. Most of the asymmetric approaches reported to date were based on chromatographic, chemical or enzymatic resolutions of the racemic derivatives. Although several enantio- or diastereoselective syntheses have been reported, moderate asymmetric inductions have been achieved except in a few cases.

Carreño and coworkers reported the first enantioselective synthesis of 7,8-dihydro[5]helicene quinones and bisquinones based on a one-pot domino process (Scheme 35). ${ }^{47}$ Treatment of vinyl 3,4-dihydrophenanthrene 136 with 2 equivalents of enantiopure (SS)-2-(p-tolylsulfinyl)-1,4-benzoquinone (137) afforded 7,8-dihydro[5]helicene quinone 138 in optically pure form with the absolute configuration $P$. The reaction sequence involved spontaneous elimination of the sulfoxide in the initially formed Diels-Alder adduct and in situ partial aromatization of the corresponding tetrahydroaromatic derivative in the 
presence of an excess of the chiral sulfinylquinone. Interestingly, the enantiodivergent synthesis of either $P$ or $M$ helimer from the same intermediate depends on the different aromatizing reagents. The helicene $(P)-\mathbf{1 3 8}$ would be formed in $67 \%$ yield with $96 \%$ ee via aromatization of the $\mathrm{B}$ ring of $\mathbf{1 3 9}(\mathrm{R}=\mathrm{TBDMS})$ with DDQ, whereas helicene $(M)-\mathbf{1 3 8}$ was obtained in $88 \%$ yield with $90 \%$ ee when the aromatization of $139(\mathrm{R}=\mathrm{Me})$ was effected with CAN.

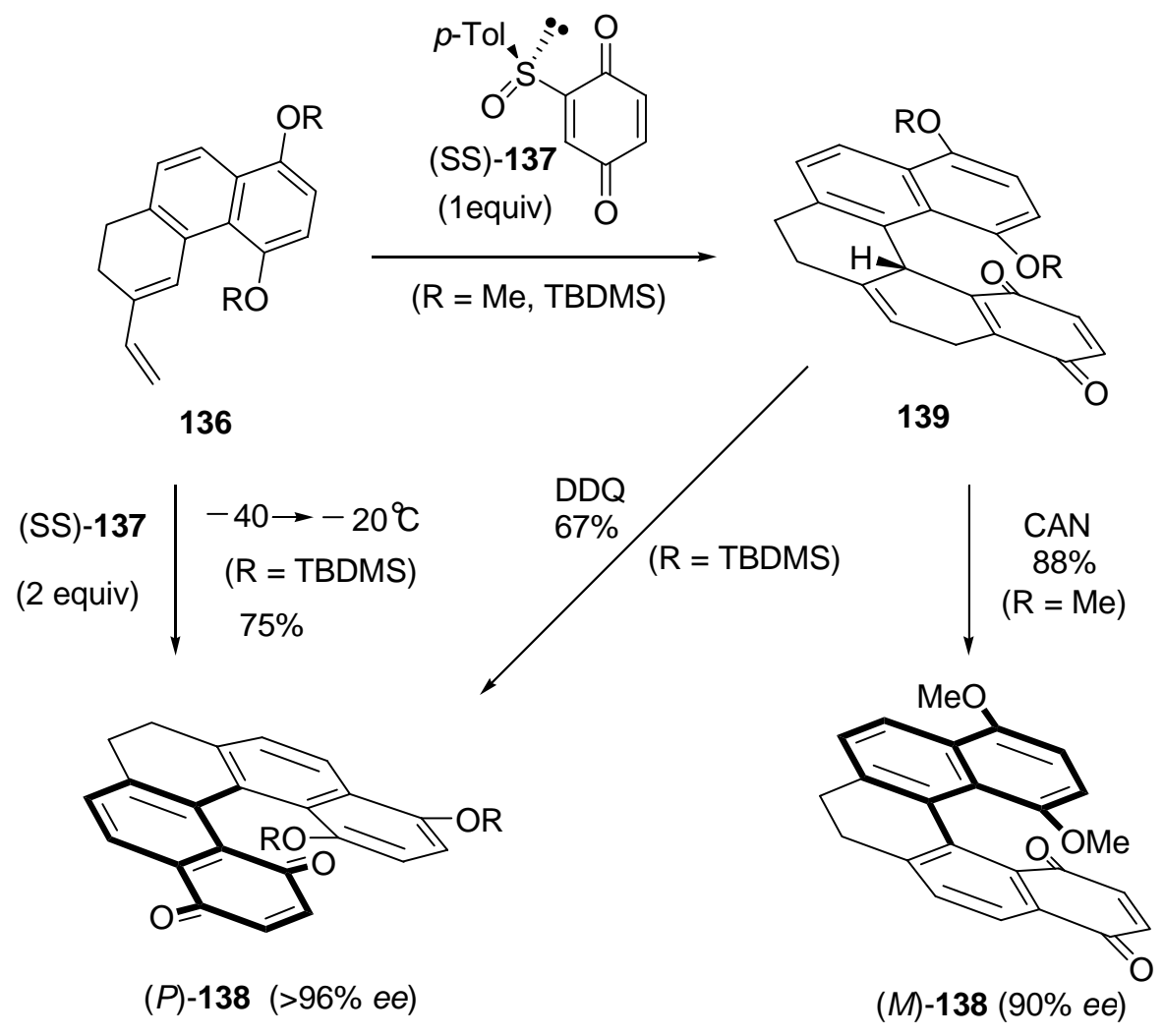

Scheme 35. Carreño's domino process for the enantiodivergent synthesis of 7,8-dihydro[5]helicene quinones.

Another asymmetric approach to [5]helicene was developed by Karikomi and coworkers through an aromatic oxy-Cope rearrangement strategy (Scheme 36). ${ }^{48}$ Condensation of chiral bicycle[2,2,2]ketone 140 with Grignard reagent 141 afforded (1R, $2 S, 4 S)-142$, followed by an asymmetric aromatic oxy-Cope rearrangement to give pentacyclic fused-ring derivative 143 in 47\% yield. $(P)$-144 was obtained from 143 in 24\% yield with $98 \%$ ee in four subsequent steps involving reduction, hydrolysis and dehydration, enolacetylation, and aromatization. The enantiomer $(M)$-144 was likewise synthesized from 
$(1 S, 4 R)-140$.

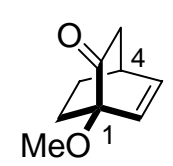

$(1 R, 4 S)-140$
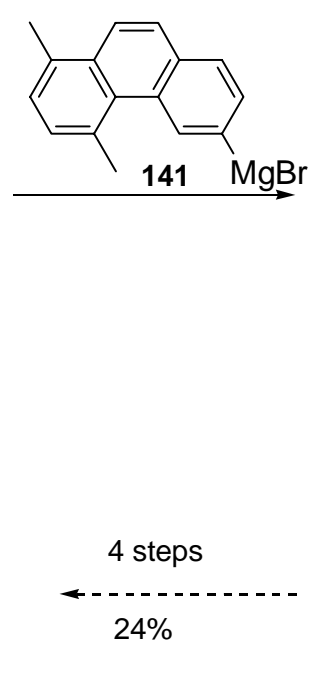

(p)-144 (>98\% ee)

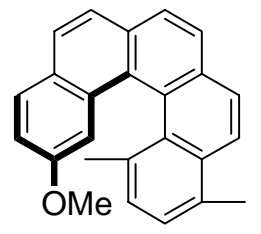

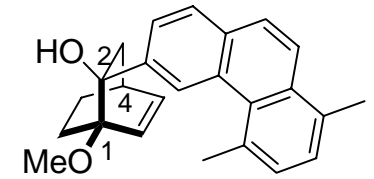

$(1 R, 2 S, 4 S)-142,60 \%$
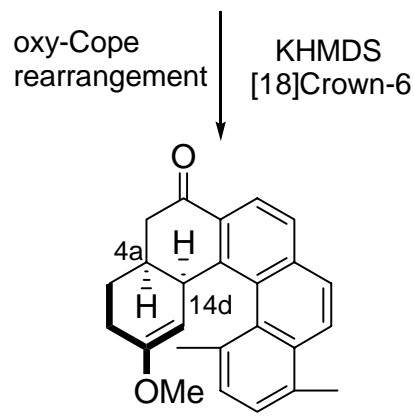

(4aS,14dR)-143, 47\%

Scheme 36. Synthesis of [5] helicene $(P)$-144 via an aromatic oxy-Cope rearrangement.

More recently, Stará and coworkers developed a highly stereoselective cobalt-mediated [2+2+2] cycloisomerization of aromatic triynes to afford [7]helicene-like compounds (Scheme 37). ${ }^{49}$ A central-to-helical chirality transfer could be easily controlled by the absolute configuration at the asymmetric center or by the presence of substitutes of the aromatic triynes.<smiles>[R]C#C[C@H](C)OCc1ccc2ccccc2c1C#Cc1c(CCC#C)ccc2ccccc12</smiles>

(1S)-(-)-145

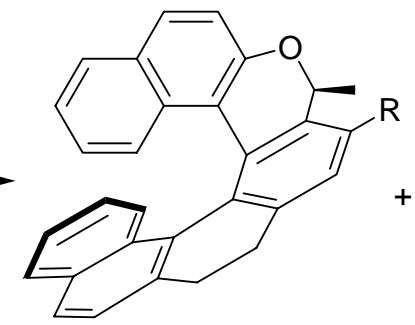

$(M, 1 S)-(-)-146$

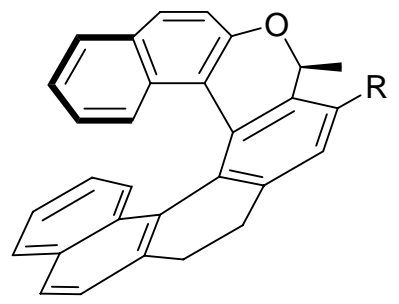

$(P, 1 S)-(+)-146$

$$
d r=92 \quad: \quad 8 \quad(\mathrm{R}=\mathrm{H})
$$

$0: 100 \quad(\mathrm{R}=p$-tolyl $)$

Scheme 37. Asymmetric synthesis of [7] helicene-like compounds via $[2+2+2]$ cycloisomerization 


\section{Chapter IV}

\section{Studies of Helical Molecules: Synthesis of Indeno-Fused Benzo[c]phenanthrene and Dibenzo[c,g]phenanthrene ([5]Helicene) with a Phenyl Substituent at the Most Sterically Hindered Position}

\section{Introduction}

We recently reported an efficient synthetic pathway outlined in Scheme 38 to produce 153 as an $11 H$-benzo[b]fluorene derivative. ${ }^{16 \mathrm{~b}}$ Condensation between lithium acetylide 46 and 2,2-dimethylpropiophenone (147) furnished propargylic alcohol 148, which was then reduced with triethylsilane in the presence of trifluoroacetic acid to give the benzannulated enediyne 149. Treatment of 149 with potassium $t$-butoxide under refluxing toluene then produced $\mathbf{1 5 3}$ in a sequence of cascade reactions. Presumably, an initial 1,3-prototropic rearrangement of $\mathbf{1 4 9}$ furnished the benzannulated enyne-allene 150, which then underwent a Schmittel cyclization reaction to generate benzofulvene biradical $151 .{ }^{2} \mathrm{~A}$ subsequent intramolecular radical-radical coupling then gave the formal Diels-Alder adduct 152 and, after a prototropic rearrangement, 11H-benzo[b]fluorene 153 in excellent yield. This synthetic pathway was adopted for the preparation of helical 4,5-diarylphenanthrene derivatives ${ }^{17}$ with one of the structures resembles that of a spiral staircase. ${ }^{50}$
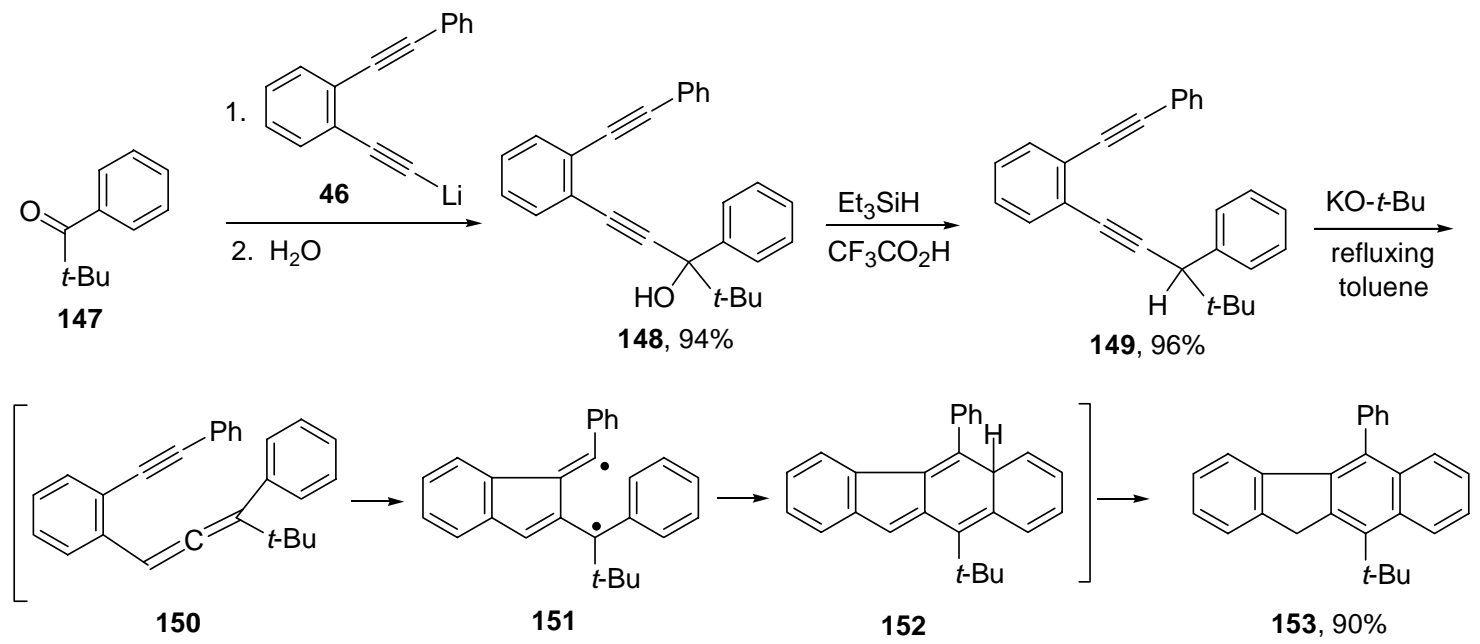

Scheme 38. Synthesis of $11 H$-benzo[b]fluorene via Schmittel cyclization reaction. 


\section{Research Objective}

We envisioned that by replacing the phenyl group of 147 with a 2-naphthyl, a 3-phenanthryl, or a 2-benzo[c]phenanthryl group, the synthetic sequence outlined in Scheme 38 could lead to fused aromatic systems having an extended conjugation and bearing a phenyl substituent at the most sterically hindered position to cause a helical twist.

\section{Literature Survey for the Synthesis Benzo[c]phenanthrene and Derivatives with a Phenyl Substituent at the Most Sterically Hindered Position}

4-Phenylphenanthrene (154) and 1-phenylbenzo[c]phenanthrene (155) could be obtained through photodehydrocyclization of the corresponding 1,4-diarylbut-1-en-3-ynes. ${ }^{51}$ For example, photocyclization of 1-(3-phenanthryl)-4-phenylbut-1-en-3-yne (156) was reported to produce 1-phenylbenzo[c]phenanthrene (155) in 50\% yield (eq 1). 10-Phenyldibenzo[ $[c, g]$ phenanthrene (1-phenylpentahelicene, 158) could be obtained along with two isomers by photocyclization of 8 '-phenyldi- $\beta$-naphthylethylene (157) (eq. 2$){ }^{52}$<smiles>C=Cc1ccc2ccc3ccccc3c2c1</smiles>

156<smiles>Pc1cccc2ccc(C=Cc3ccc4ccccc4c3)cc12</smiles>

157

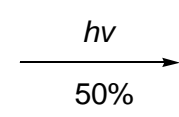

$50 \%$

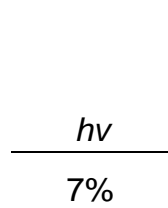

(<smiles>c1ccc(-c2cccc3ccc4ccc5ccccc5c4c23)cc1</smiles>

155<smiles></smiles>

158

\section{Results and Discussion}

\section{1. Synthesis of Aryl Ketones 160}

The requisite aryl ketone 160a was prepared by treatment of commercially available 2-naphthoyl chloride (159a) with $t$-butylcopper, prepared from $t$-butyllithium and $\mathrm{CuBr} \cdot \mathrm{SMe}_{2}$ (eq 3). Similarly, aryl ketones 160b and 160c were prepared by converting the corresponding carboxylic acids $159 \mathrm{~b}$ and 159c to the acid chlorides with thionyl chloride followed by treatment with $t$-butylcopper (eq 4). 3-Phenanthrenecarboxylic acid (159b) was prepared from commercially available 3 -acetylphenanthrene as reported previously. ${ }^{53}$ 
<smiles>O=C(Cl)c1ccc2ccccc2c1</smiles>

$159 a$

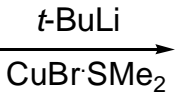<smiles>O=C(O)Br</smiles><smiles></smiles>

159b: $\mathrm{Ar}=3$-phenanthryl 159c: $A r=2-$ benzo[c]phenanthryl<smiles>O=C(Br)c1ccc2ccccc2c1</smiles>

$160 a, 100 \%$

$$
\overbrace{t-\mathrm{Bu}}^{\mathrm{O}} \mathrm{Ar}
$$

160b, $95 \%$

160c, $64 \%$

A synthetic procedure for benzo[c]phenanthrene-2-carboxylic acid (159c) involving oxidation of 2-methylbenzo[c]phenanthrene was reported previously. ${ }^{54}$ An alternative synthetic sequence was used to prepare 159c (Scheme 39). The Wittig reaction between 2-(bromomethyl)naphthalene (161) and methyl 4-formylbenzoate (162), using lithium ethoxide as the base, produced ethyl 4-[2-(2-naphthalenyl)ethenyl]benzoate (163) as a mixture of the trans and cis isomers (trans:cis $=5.5: 4.5)$. A subsequent photochemical cyclization reaction $^{55}$ furnished ethyl benzo[c]phenanthrene-2-carboxylate (164), which then was hydrolyzed to give 159c.
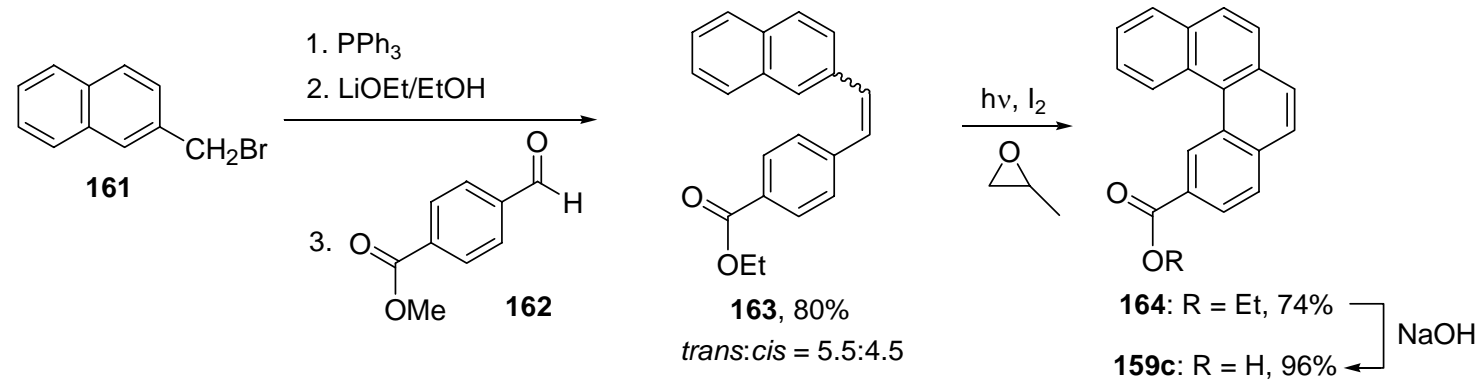

Scheme 39. Synthesis of benzo[c]phenanthrene-2-carboxylic acid through photocyclization.

\section{2. Synthesis of Indeno-Fused Phenanthrene 167 and Related Derivatives}

The use of 160a-c for condensation with 46 furnished propargylic alcohols 165a-c, which were reduced with triethylsilane in the presence of trifluoroacetic acid to afford the benzannulated enediynes 166a-c (Table 1). Treatment of 166a-c with potassium $t$-butoxide under refluxing toluene converted them to the indeno-fused phenanthrene 167a, benzo $[c]$ phenanthrene 167b, and dibenzo[c,g]phenanthrene ([5]helicene]) 167c, respectively, 
with a phenyl substituent at the most sterically hindered position in a single operation. The parent 4-phenylphenanthrene (154), ${ }^{51}$ 1-phenylbenzo[c]phenanthrene $(\mathbf{1 5 5}),{ }^{51}$ and 10-phenyldibenzo[c,g]phenanthrene (1-phenylpentahelicene), ${ }^{52}$ and related compounds ${ }^{51,52,56}$ were prepared previously by photodehydrocyclization reactions.

Table 1. Synthesis of Phenanthrene 167a, Benzo[c]phenanthrene 167b, and Dibenzo[c,g]phenanthrene 167c

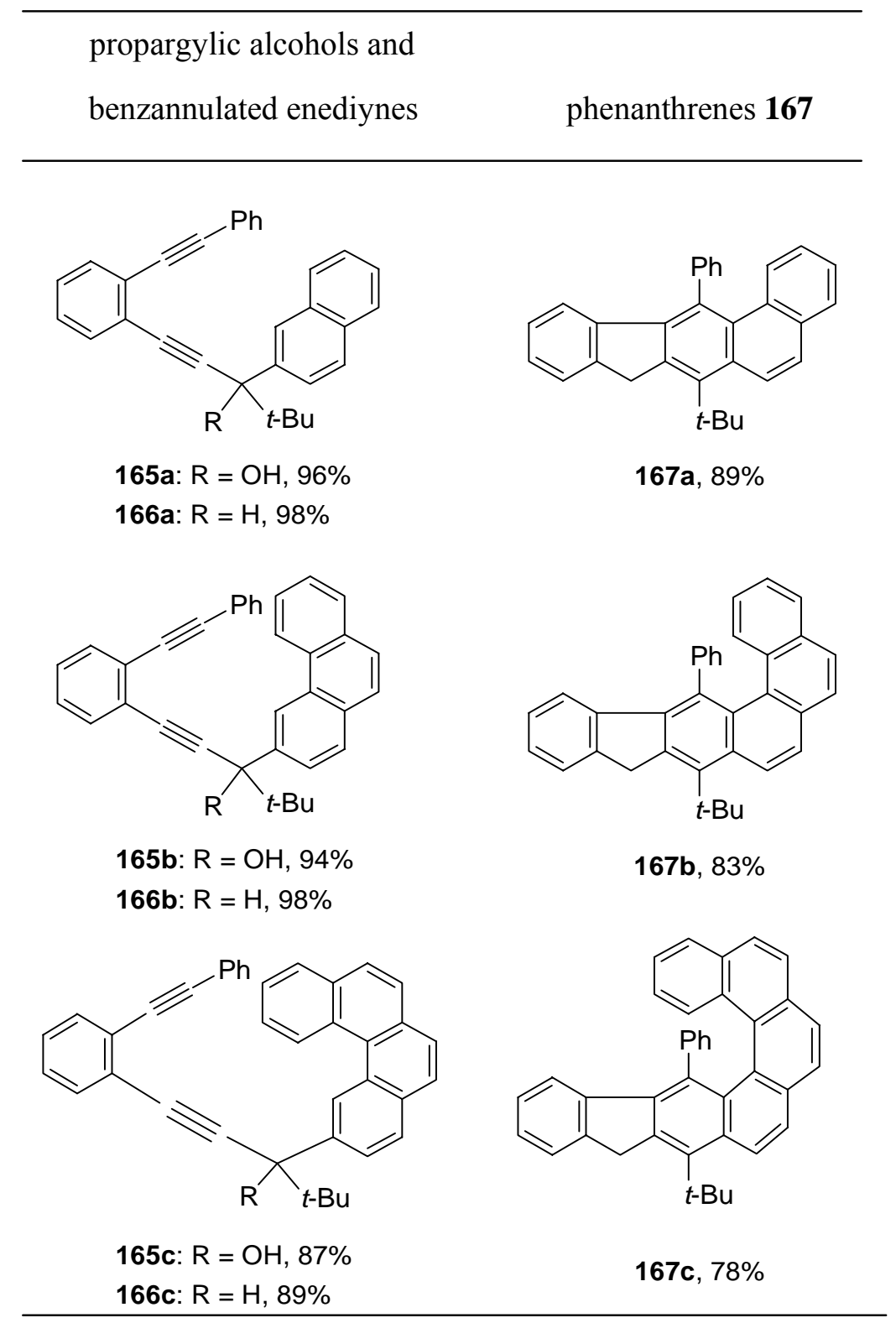

\section{3. Products of $[2+2]$ Cycloaddition Reaction}

Minor amounts of 168b (ca. 2\%) and 168c (ca. 12\%), derived from the intramolecular $[2+2]$ cycloaddition reactions of the corresponding benzannulated 
enyne-allene precursors, were also produced as observed previously. ${ }^{16,50}$

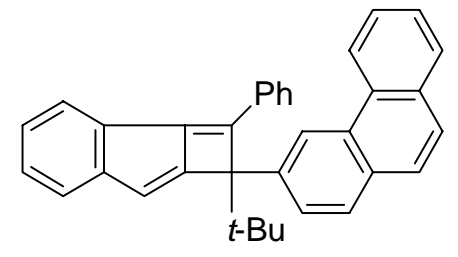

$168 b$

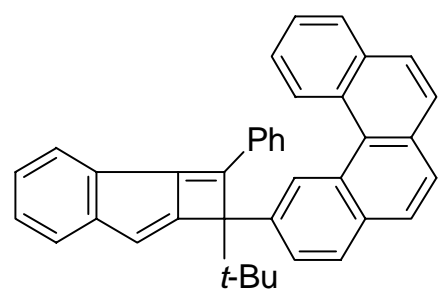

$168 \mathrm{c}$

\section{4. Structure Analysis of 167}

It is worth noting that the intramolecular radical-radical coupling reaction of the biradical derived from 166a involved only the $\alpha$-position of the naphthyl ring to produce 167a preferentially. Attaching the $\beta$-position to form an indeno-fused anthracene derivative did not appear to occur. The higher reactivity of the $\alpha$-position than the $\beta$-position of naphthalene in homolytic addition may be responsible for the regioselectivity. ${ }^{57} \mathrm{~A}$ similar preference could also account for the formation of the angularly fused $167 \mathrm{~b}$ and $167 \mathrm{c}$.

Recorded on a $600 \mathrm{MHz}$ NMR spectrometer, the ${ }^{1} \mathrm{H}$ NMR signal of the two hydrogens on the five-membered ring of $\mathbf{1 6 7 a}$ in $\mathrm{CDCl}_{3}$ appeared as a singlet at $\delta 4.45$. This observation is consistent with the planar geometry of the indeno[2,1-b]phenanthrene ring system of 167a with the phenyl substituent oriented essentially perpendicular to the phenanthrene ring as observed in the X-ray structure (Figure 3).

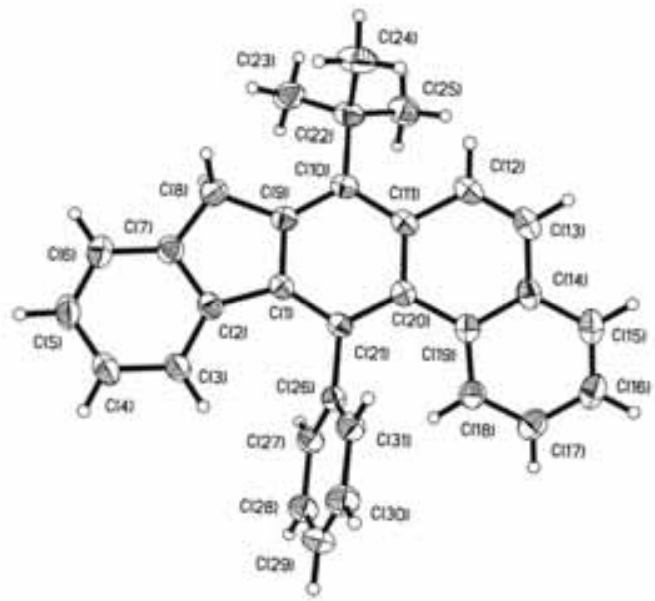

Figure 3. ORTEP drawing of the crystal structure of 167a. 
Interestingly, the ${ }^{1} \mathrm{H}$ NMR signals of the methylene hydrogens of $\mathbf{1 6 7 b}$ in $\mathrm{CDCl}_{3}$, also recorded on a $600 \mathrm{MHz}$ NMR spectrometer at $25^{\circ} \mathrm{C}$, exhibited as an $\mathrm{AB}$ quartet at $\delta$ 4.55 and 4.34 with a coupling constant of $20.7 \mathrm{~Hz}$, indicating that the indeno-fused benzo $[c]$ phenanthrene ring system with the phenyl substituent at the most sterically hindered position is nonplanar, and the rate of racemization is relatively slow on the NMR time scale. As a result, the methylene hydrogens are diastereotopic, exhibiting a large geminal coupling constant. The helical nature of the structures of several 1-phenylbenzo $[c]$ phenanthrene derivatives was established by temperature-dependent NMR studies earlier. ${ }^{51 \mathrm{~b}}$ The rate of racemization with the phenyl group moving from one side of the helical twist to the other side was determined to be ca. $16 \mathrm{kcal} / \mathrm{mol}$. The well resolved $\mathrm{AB}$ quartet of the ${ }^{1} \mathrm{H} \mathrm{NMR}$ signals of the methylene hydrogens of $\mathbf{1 6 7 b}$ also provided an opportunity to determine the activation barrier of racemization by temperature-dependent NMR studies. However, the AB signals of 167b in 1,1,2,2-tetrachloroethane- $d_{2}$, recorded on a $270 \mathrm{MHz}$ NMR spectrometer, remained well separated and exhibited essentially no line broadening at $125{ }^{\circ} \mathrm{C}$, indicating that the rate of the helix inversion is relatively slow on the NMR time scale. The $\Delta G^{\sharp}$ rac of 167b is estimated to be at least $19.4 \mathrm{kcal} / \mathrm{mol}$ on the basis of the $\mathrm{AB}$ signals at $\delta 4.60$ and $4.39\left(\delta_{\mathrm{A}}-\delta_{\mathrm{B}}=56.6 \mathrm{~Hz}\right)$ with a coupling constant of $20.7 \mathrm{~Hz}$ at $125^{\circ} \mathrm{C}$. The higher energy barrier for racemization than those of earlier cases may be attributed to the buttressing effect of the fused indeno group and the $t$-butyl substituent in $\mathbf{1 6 7 \mathbf { b }}$ as observed previously in the related systems. ${ }^{17,51}$

The ${ }^{1} \mathrm{H}$ NMR spectrum of $\mathbf{1 6 7 b}$ in $\mathrm{CDCl}_{3}$ recorded on a $600 \mathrm{MHz} \mathrm{NMR}$ spectrometer at $25{ }^{\circ} \mathrm{C}$ also showed four broad humps at $\delta 8.01,7.33,6.72$, and 6.07. At -20 ${ }^{\circ} \mathrm{C}$, the signals at $\delta 8.01$ and 6.07 became doublets and the signals at $\delta 7.33$ and 6.72 became triplets, attributable to the ortho and meta hydrogens on the phenyl substituent, respectively. The fact that four separate signals were observed suggests that rotation around the carbon-carbon single bond attaching the phenyl substituent to the benzo[c]phenanthrene ring system is restricted on the NMR time scale. The signals of the ortho hydrogens coalesced at ca. $60{ }^{\circ} \mathrm{C}$ and the signals of the meta hydrogens coalesced at ca. $50{ }^{\circ} \mathrm{C}$, corresponding to a rotational barrier of ca. $14.5 \mathrm{kcal} / \mathrm{mol}$, which is slightly higher than the 
rotational barriers of ca. $13 \mathrm{kcal} / \mathrm{mol}$ of several other 1-phenylbenzo[c]phenanthrene derivatives reported earlier. ${ }^{51 \mathrm{~b}}$

Compared to $\mathbf{1 6 7 b}$, the structural distortion of $167 \mathbf{c}$ with an additional fused benzene ring could be expected to be even more profound. The X-ray structure of 167c (Figure 4) showed that the indeno-fused dibenzo[c,g]phenanthrene ([5]helicene) skeleton is severely twisted to minimize unfavorable van der Waal's contact with the $\pi$ electrons of the phenyl substituent at the most sterically hindered position. The acute dihedral angle between the mean planes of the benzene ring bearing the phenyl substituent and the benzene ring at the other end of the [5]helicene system is pronounced $58.4^{\circ}$ from planarity. The phenyl substituent is oriented at a $60.6^{\circ}$ angle from the mean plane of the benzene ring where it is attached.

As in 167b, the $\mathrm{AB}$ quartet of the methylene hydrogens of 167c in 1,1,2,2-tetrachloroethane- $d_{2}$ at $\delta 4.63$ and $4.35\left(\delta_{\mathrm{A}}-\delta_{\mathrm{B}}=77.8 \mathrm{~Hz}, J=21.1 \mathrm{~Hz}\right)$, recorded on a $270 \mathrm{MHz}$ NMR spectrometer, remained well separated and exhibited essentially no line broadening at $125^{\circ} \mathrm{C}$, corresponding to a $\Delta G^{\ddagger}$ rac of at least $19.3 \mathrm{kcal} / \mathrm{mol}$. The ${ }^{1} \mathrm{H}$ NMR signals of the ortho hydrogens on the phenyl substituent appeared as doublets at $\delta 6.43$ and 5.75 , whereas those of the meta hydrogens appeared as overlapping triplets at $\delta 6.56$ and 6.54. The coalescence temperature of the ortho hydrogens was determined to be at $100{ }^{\circ} \mathrm{C}$, corresponding to a higher rotational barrier of $17.5 \mathrm{kcal} / \mathrm{mol}$ than the rotational barrier of $14.5 \mathrm{kcal} / \mathrm{mol}$ of $\mathbf{1 6 7 b}$.

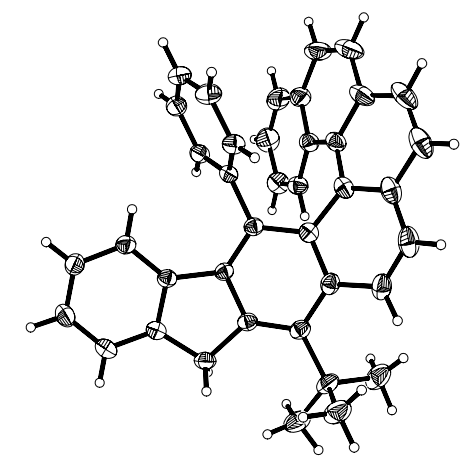

Figure 4. Perspective view of the molecular structure of $167 \mathrm{c}$ with the thermal ellipsoids scaled to enclose $30 \%$ probability. 


\section{Conclusions}

The indeno-fused phenanthrene 167a, benzo[c]phenanthrene 167b, and dibenzo $[c, g]$ phenanthrene 167c, bearing a phenyl substituent at the most sterically hindered position were readily synthesized from the benzannulated enediynyl propargylic alcohols 165a-c. The fused aromatic ring systems of $167 \mathbf{b}$ and $167 \mathrm{c}$ possess a helical twist and the rotation of the phenyl substituent is restricted. The X-ray structure of 167c allowed direct measurement of the extent of distortion from planarity. 


\section{Chapter V}

\section{Synthesis of Helical Derivatives of Indenofluorene via Schmittel Cyclization Reaction of Benzannulated Enyne-Allenes}

\section{Introduction}

Biradicals generated from Schmittel cyclization reaction of benzannulated enyne-allenes provide many opportunities for subsequent synthetic applications to give formal Diels-Alder adducts. ${ }^{14,15}$ For example, as reported earlier we adopted an efficient synthetic pathway outlined in Scheme 40 for the synthesis of indeno-fused benzo $[c]$ phenanthrene 167a. Condensation between lithium acetylide 46 and aryl ketone 160a furnished propargylic alcohol 165a, which was then reduced with triethylsilane in the presence of trifluoroacetic acid to give the benzannulated enediyne 166a. Treatment of 166a with potassium $t$-butoxide in refluxing toluene then produced 167a by a sequence of cascade reactions. The transformation from 166a to 167a involved initially a prototropic rearrangement to form the benzannulated enyne-allene 168. A subsequent Schmittel cyclization reaction produced biradical 169 followed by an intramolecular radical-radical coupling reaction leading to the formal Diels-Alder adduct 170, which in turn underwent tautomerization to give 167a.<smiles>CC(C)(C)C(=O)c1ccc2ccccc2c1</smiles>

$160 \mathrm{a}$

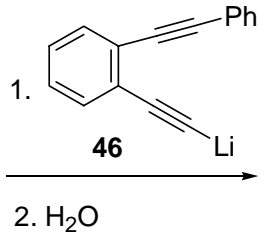

2. $\mathrm{H}_{2} \mathrm{O}$

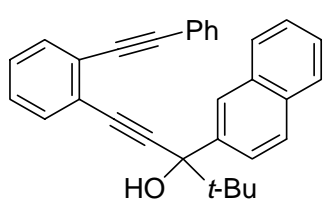

$165 \mathrm{a}, 96 \%$

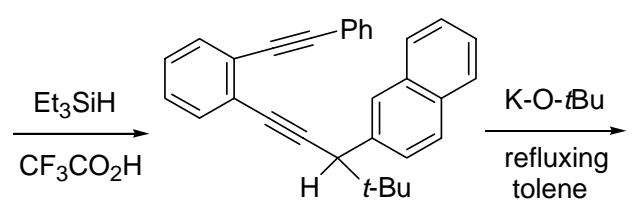

$166 a, 98 \%$

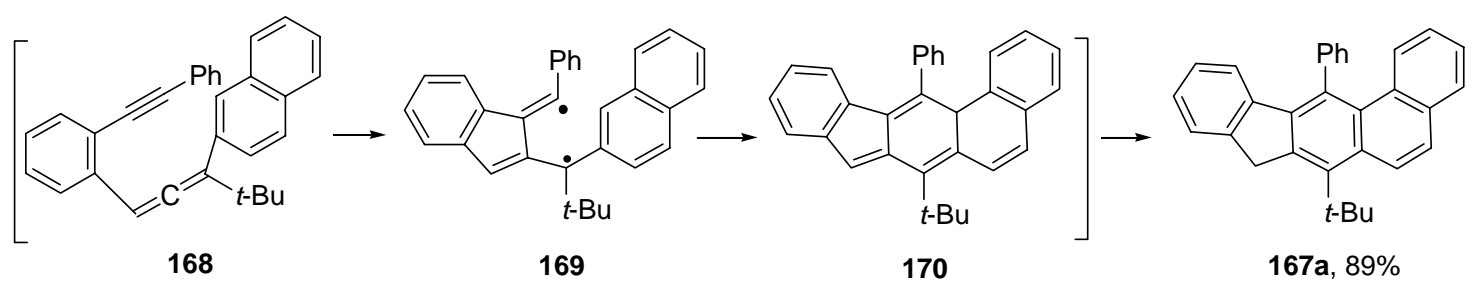

Scheme 40. Synthesis of phenanthrene 167a via the Schmittel cyclization reaction.

\section{Research Objective}

We envisioned that by replacing 46 with tetraacetylene 171a, the synthetic sequence outlined in Scheme 40 could lead to the derivatives of indenofluorene through double formal 
intramolecular Diels-Alder reactions.

\section{Literature Survey for the Synthesis of the Derivatives of Indenofluorene}

Indenofluorene was first synthesized by Nierenstein and Webster in 1945 as a minor product called ellagene by distillation of ellagic acid with zinc dust. ${ }^{58}$ Double Friedel-Crafts cyclization reactions were employed as a key step for the synthesis of derivatives of indenofluorene. ${ }^{59}$

\section{Results and Discussion}

\section{1. Synthesis of 179a, 182a and 185}

The use of tetraacetylene 171a for the condensation reaction with aryl ketone 147 furnished propargylic alcohol 172a, which was reduced with triethylsilane in the presence of trifluoroacetic acid to afford tetraacetylenic hydrocarbon 173a. Treatment of 173a with potassium $t$-butoxide in refluxing toluene efficiently furnished 179a through double formal Diels-Alder reactions (Scheme 41).

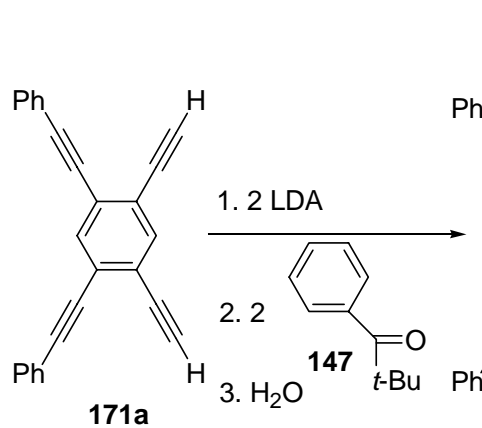

$171 \mathrm{a}$

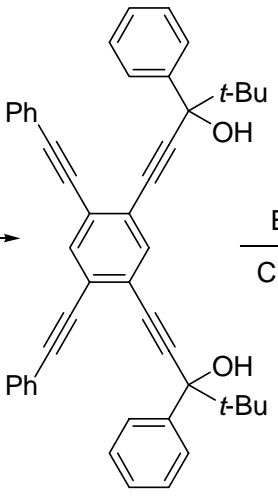

$172 a, 87 \%$

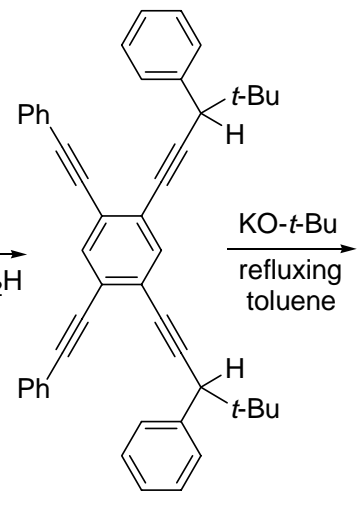

173a, $85 \%$

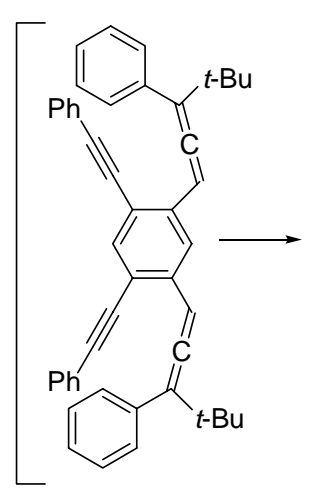

174

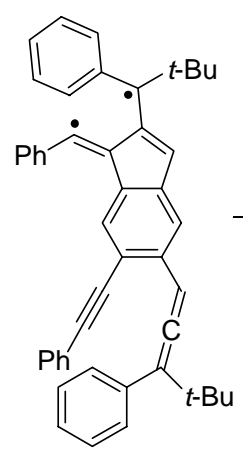

175

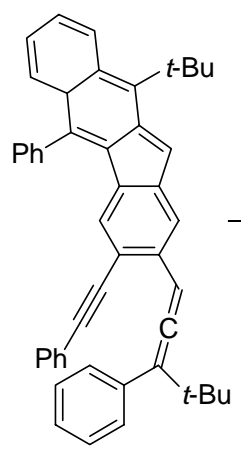

176

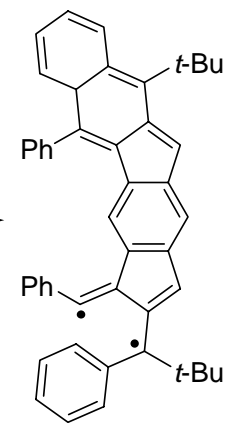

177

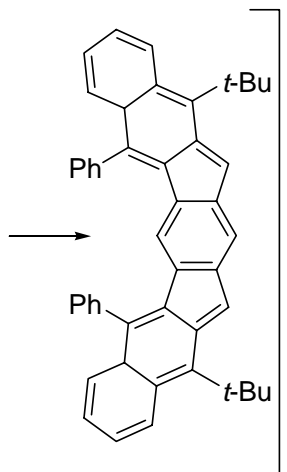

178

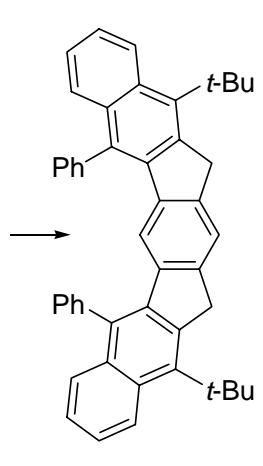

$179 a, 87 \%$

Scheme 41. Synthesis of phenanthrene 179a via the Schmittel cyclization reactions. 
By replacing the phenyl group of $\mathbf{1 4 7}$ with a 2-naphthyl, or a 3-phenanthryl group, the synthetic sequence outlined in Scheme 41 led to the fused aromatic systems 182a and 185, respectively, with more extended conjugations.

Table 2. Synthesis of 182a, 185

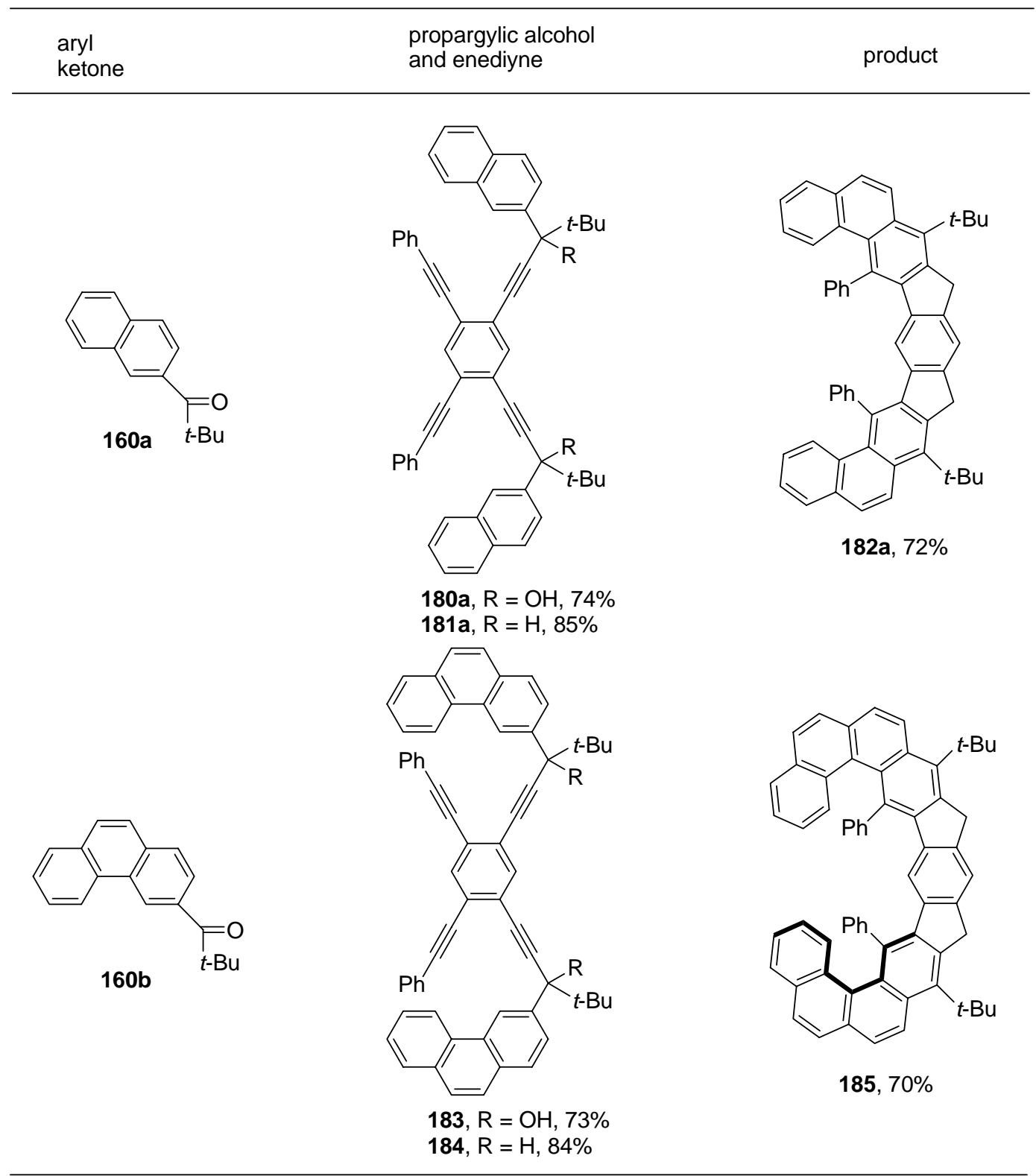

\section{2. Structure Analysis of 179a, 182a and 185}

It is worth noting that the intramolecular radical-radical coupling reaction of the biradical derived from 181a involved only the $\alpha$-position of the naphthyl ring to produce 182a preferentially as observed earlier. The higher reactivity of the $\alpha$-position than the $\beta$-position of the naphthyl ring in homolytic addition may be responsible for the 
regioselectivity. ${ }^{57}$ A similar preference could also account for the formation of $\mathbf{1 8 5}$.

Recorded on a $600 \mathrm{MHz}$ NMR spectrometer, the ${ }^{1} \mathrm{H}$ NMR signal of the methylene hydrogens on the five-membered rings of 179a in $\mathrm{CDCl}_{3}$ appeared as a singlet at $\delta 4.52$, indicating that the rate of racemization is faster than the NMR time scale. As a result, the methylene hydrogens were observed as a singlet. Similarly, the singlet at $\delta 4.46$ of the methylene hydrogens on the five-membered rings of 182a also indicates a rapid rate of racemization.

However, the distorted structure with a helical twist in $\mathbf{1 8 5}$ was manifested with a set of $\mathrm{AB}$ quartet at $\delta 4.53$ and 4.44 from the diastereotopic methylene hydrogens on the five-membered rings, as observed earlier in the structurally related the indeno-fused benzo[c]phenanthrene ring system of 167b with a phenyl substituent at the most sterically hindered position.

\section{3. An Alternative Synthetic Pathway to Helical Structure}

The distorted structure in the conjugated indenofluorene ring system could also be produced by an alternative approach. It could be envisaged that by replacing the two phenyl substituents of 179a and 182a with two longer 4-(tert-octyl)phenyl groups (tert-octyl = 1,1,3,3-tetramethylbutyl), unfavorable van der Waal's contact between the two longer substituents would be produced. As a result, the indenofluorene ring system had to adopte a helical conformation to minimize the steric repulsion. By replacing phenyl substituents with 4-(tert-octyl)phenyl groups, the synthetic sequence in Scheme 41 could lead to $\mathbf{1 7 9 b}$ and 182b (Table 3).

\section{4. Structure Analysis of $179 b$ and $182 b$}

As expected, steric hindrance between the two longer 4-(tert-octyl)phenyl groups causes a helical twist in $\mathbf{1 7 9 b}$ and $\mathbf{1 8 2 b}$, also manifested each with $A B$ quartet with a large coupling constant 
Table 3. Synthesis of $179 b$ and $182 b$

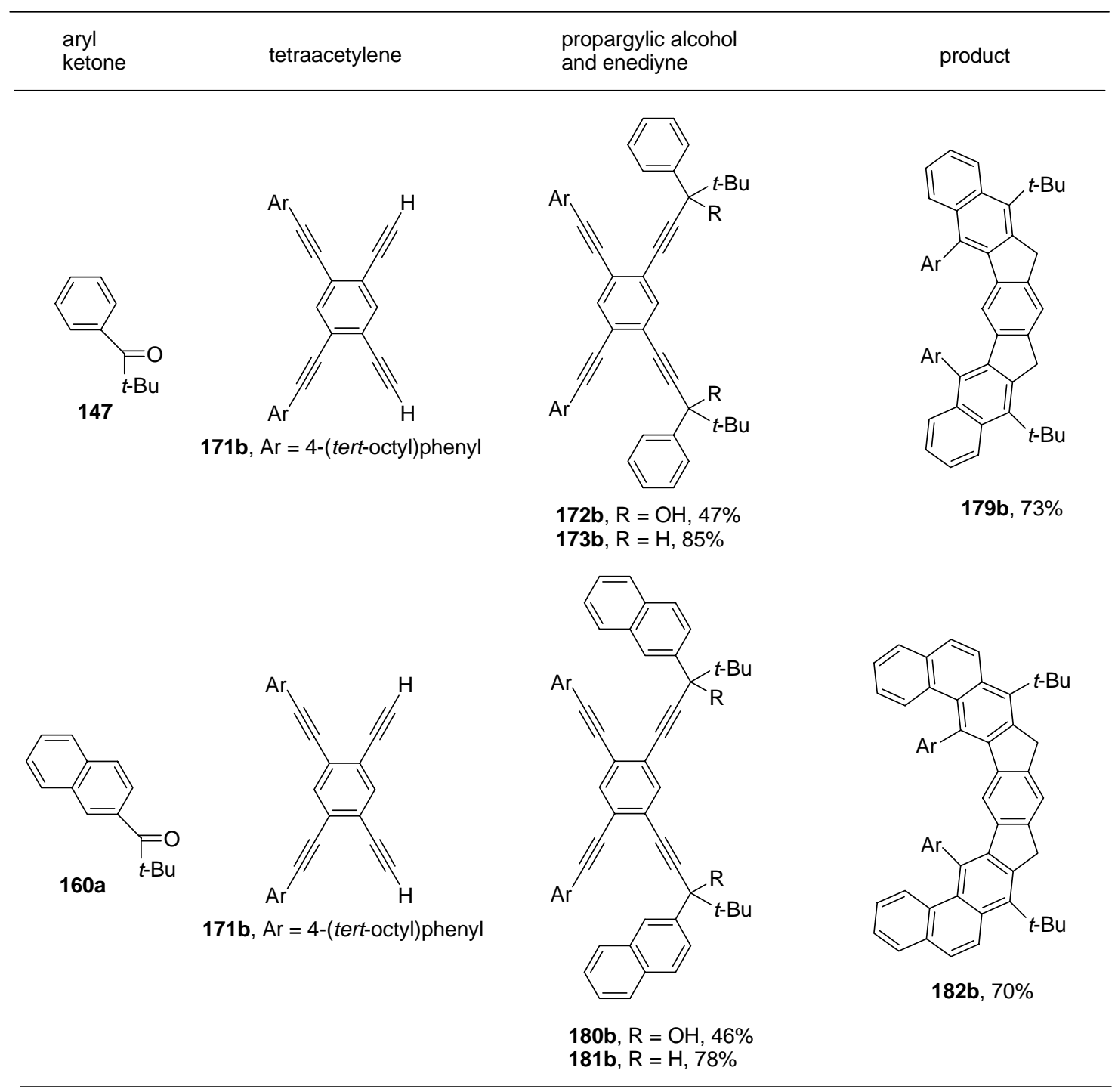

\section{5. Synthesis of Tetraacetylenes 171}

Tetraacetylene 171a was prepared by two Sonogashira reactions between 1,5-dibromo-2,4-diiodobenzene $(\mathbf{1 8 6})^{60}$ and phenylacetylene 187a to afford 188a. Two bromo to iodo exchanges followed by cross-coupling reactions with (trimethylsilyl)acetylene produced 189a, which was desilylated to afford 171a. Tetraacetylene 171b was likewise synthesized (Scheme 42). 


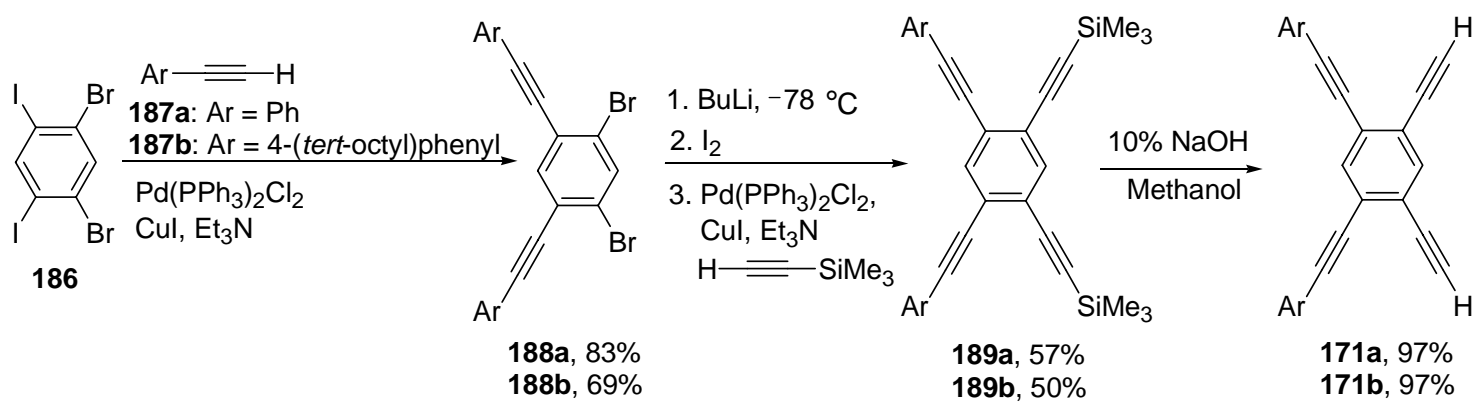

Scheme 42. Synthesis of tetraacetylenes 171a and 171b.

\section{Conclusions}

Several derivatives of indenofluorene ring system were efficiently synthesized via double formal Diels-Alder reactions. Two different synthetic approaches for the helical structures were developed. 


\section{Chapter VI}

\section{Studies of Helical Molecules: Efficient Synthesis of Overcrowded Molecules of \\ Diindeno-Fused 1,12-Diphenylbenzo[c]phenanthrene and \\ 1,14-Diphenyldibenzo[c,g]phenanthrene}

\section{Introduction}

1,12-Disubstituted benzo[c]phenanthrenes $\mathbf{1 9 0}$ and analogs were known as overcrowded molecules. ${ }^{61}$ Because of steric hindrance, the aromatic system of the 1,12-disubstituted benzo[c]phenanthrenes is distorted and the two substitutents are bent out of the plane of the aromatic rings. X-ray structure analysis shows that 1,12-dimethylbenzo[c]phenanthrene (190a) is nonplanar. ${ }^{62}$ Further evidence of nonplanarity was provided by resolution of 1,12-dimethylbenzo[c]phenanthrenes-5-acetic acid (190b). ${ }^{63}$ The optical stability of the molecule is high, with racemization occurring only at ca. $250{ }^{\circ} \mathrm{C}$.

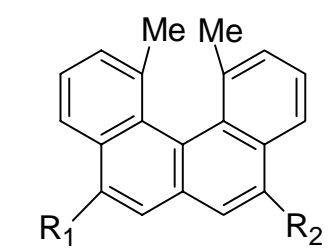

190a: $R_{1}=R_{2}=H$ 190b: $\mathrm{R}_{1}=\mathrm{H}, \mathrm{R}_{2}=\mathrm{CH}_{2} \mathrm{CO}_{2} \mathrm{H}$

190c: $\mathrm{R}_{1}=\mathrm{OH}, \mathrm{R}_{2}=\mathrm{CO}_{2} \mathrm{Me}$

190d: $R_{1}=R_{2}=C H O$

190e: $R_{1}=R_{2}=C N$

190f: $\mathrm{R}_{1}=\mathrm{R}_{2}=\mathrm{CH}_{2} \mathrm{NH}_{2}$

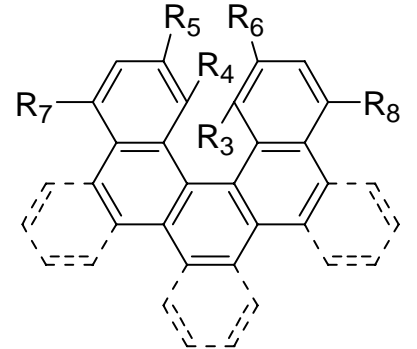

191a: $R_{3}=R_{4}=R_{7}=R_{8}=M e, R_{5}=R_{6}=H$

191b: $R_{3}=R_{4}=R_{7}=R_{8}=M e, R_{5}=R_{6}=B r$

191c: $R_{3}=R_{4}=R_{7}=R_{8}=M e, R_{5}=R_{6}=C H O$

191d: $R_{3}=R_{4}=P h, R_{5}=R_{6}=R_{7}=R_{8}=H$

Figure 4. Examples of Overcrowded Molecules

\section{Research Objective}

We envisioned that replacing the methyl groups with sterically more demanding phenyl groups in the overcrowded fjord region could lead to even more distorted structures.

\section{Literature Survey for the Synthesis of Overcrowded Molecules}

Several synthetic methods for 1,12-dimethylbenzo[c]phenanthrenes 190, 1,14-disubstituted dibenzo[c,g]phenanthrenes 191, and related compounds have been reported, ${ }^{61,63,64}$ including intramolecular Friedel-Crafts cyclization reactions followed by aromatization (Scheme 43) $)^{64 a}$ and photochemically induced dehydrocyclization of stilbenes (Scheme 44). ${ }^{64 \mathrm{f}}$ 
<smiles>Cc1ccccc1C(c1ccccc1C)C(CC(=O)O)CC(=O)O</smiles>

192

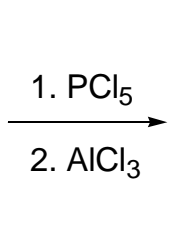$$
\text { (1) }
$$

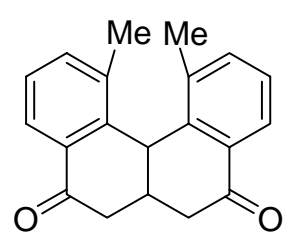

$193,62 \%$

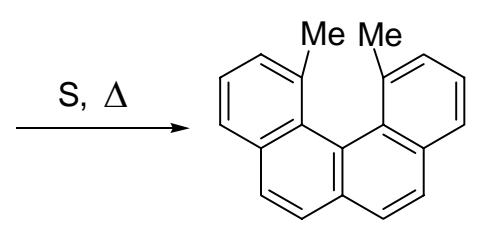

190a, $19 \%$

Scheme 43. Synthesis of 1,12-dimethylbenzo[c]phenanthrene.<smiles></smiles>

194

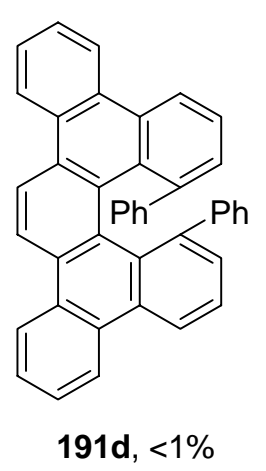

191d, $<1 \%$

Scheme 44. Synthesis of 14,15-diphenyldibenzo[f,j]picene.

We recently reported ${ }^{17}$ the use of the Schmittel cyclization reaction of the benzannulated enyne-allenes 59 for the synthesis of 4,5-diarylphenanthrenes 60 (Scheme 13). Our continued interest in nonplanar polycyclic aromatic compounds led us to apply this method for the synthesis of 1,12-diphenylbenzo[c]phenanthrene 204a and 1,14-diphenyldibenzo[c,g]phenanthrene 204b.

\section{Results and Discussion}

\section{1. Synthesis of Overcrowded Molecules 204}

Aryl ketone 196a was obtained by converting the corresponding carboxylic acid $195 \mathbf{a}^{65}$ to the acid chloride with thionyl chloride followed by treatment with $t$-butylcopper, prepared from $t$-butyllithium and $\mathrm{CuBr} \cdot \mathrm{SMe}_{2}$ (Scheme 45). Condensation between diketone 196a and the lithium acetylide 46 furnished the benzannulated enediynyl propargylic alcohol 197a as an essentially 1:1 mixture of diastereomers. Treatment of 197a with triethylsilane in the presence of trifluoroacetic acid produced tetraacetylenic hydrocarbon 198a also as an essentially 1:1 mixture of diastereomers. On exposure to potassium tert-butoxide under refluxing toluene for $3 \mathrm{~h}$, hydrocarbon 198a was transformed to 1,12-diphenylbenzo-[c]phenanthrene 204a. The transformation from 198a to 204a presumably involved a cascade of reactions including an initial prototropic rearrangement to form the benzannulated 
enyne-allene 199 followed by two Schmittel cyclization reactions and intramolecular radical-radical coupling reactions to form the formal Diels-Alder adduct 203, and subsequently, after prototropic rearrangements, 204a.<smiles>[R]C(=O)c1ccc2ccc(C([R])=O)cc2c1</smiles>
i, ii

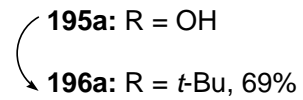

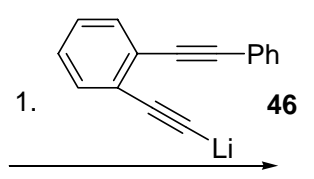

2. $\mathrm{H}_{2} \mathrm{O}$

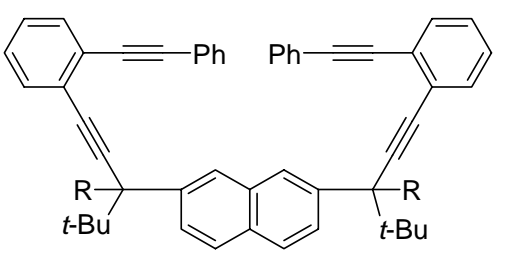

iii

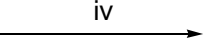

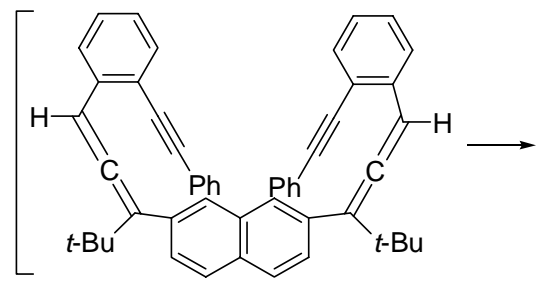

199

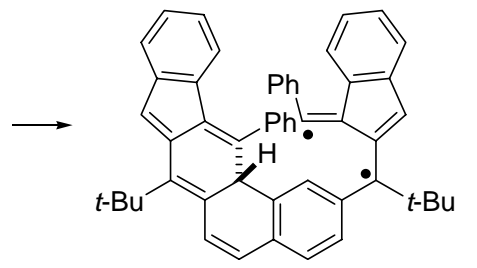

202

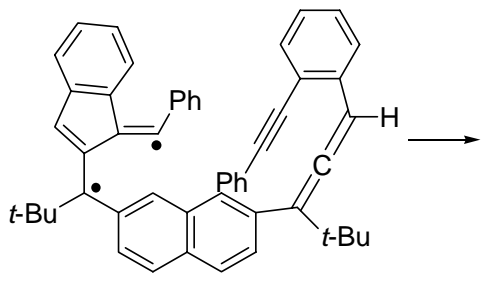

200

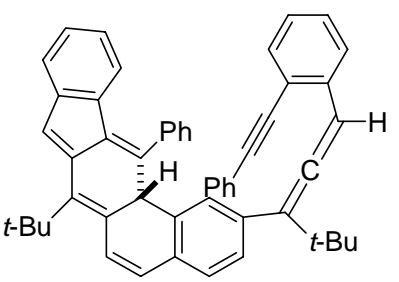

201

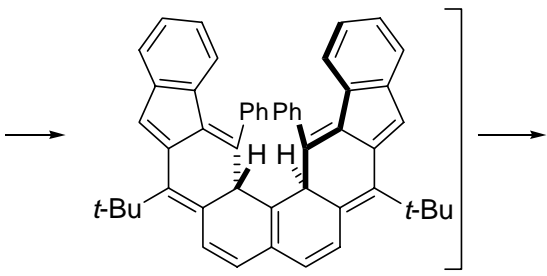

203

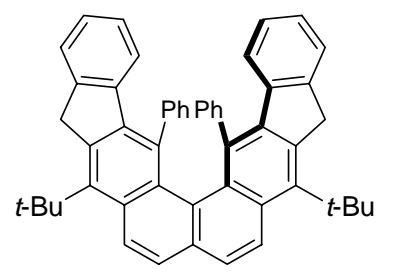

204a, $10 \%$

Conditions: (i) $\mathrm{SOCl}_{2}$, reflux. (ii) $\mathrm{CuBr} \cdot \mathrm{SMe}_{2}, t-\mathrm{BuLi},-50^{\circ} \mathrm{C}$. (iii) $\mathrm{Et}_{3} \mathrm{SiH}, \mathrm{CF}_{3} \mathrm{CO}_{2} \mathrm{H}$. (iv) $\mathrm{KO}-t-\mathrm{Bu}$, refluxing toluene.

Scheme 45. Synthesis of 1,12-diphenylbenzo[c]phenanthrene 204a.

The synthetic sequence outlined in Scheme 45 was also adopted to convert 3,6-phenanthrene dicarboxylic acid $(\mathbf{1 9 5 b})^{66}$ to 1,14-diphenyldibenzo[c,g]phenanthrene 204b (Table 4). Compared to the observation ${ }^{64 f}$ that only trace amount $(<1 \%)$ 191d having a similar structure was obtained by photocyclization of diarylethylene (Scheme 44), the synthetic pathway for 204b provides a viable alternative for the preparation of highly congested 1,14-diphenyldibenzo[c,g]phenanthrenes. 
Table 4. Synthesis of 204b

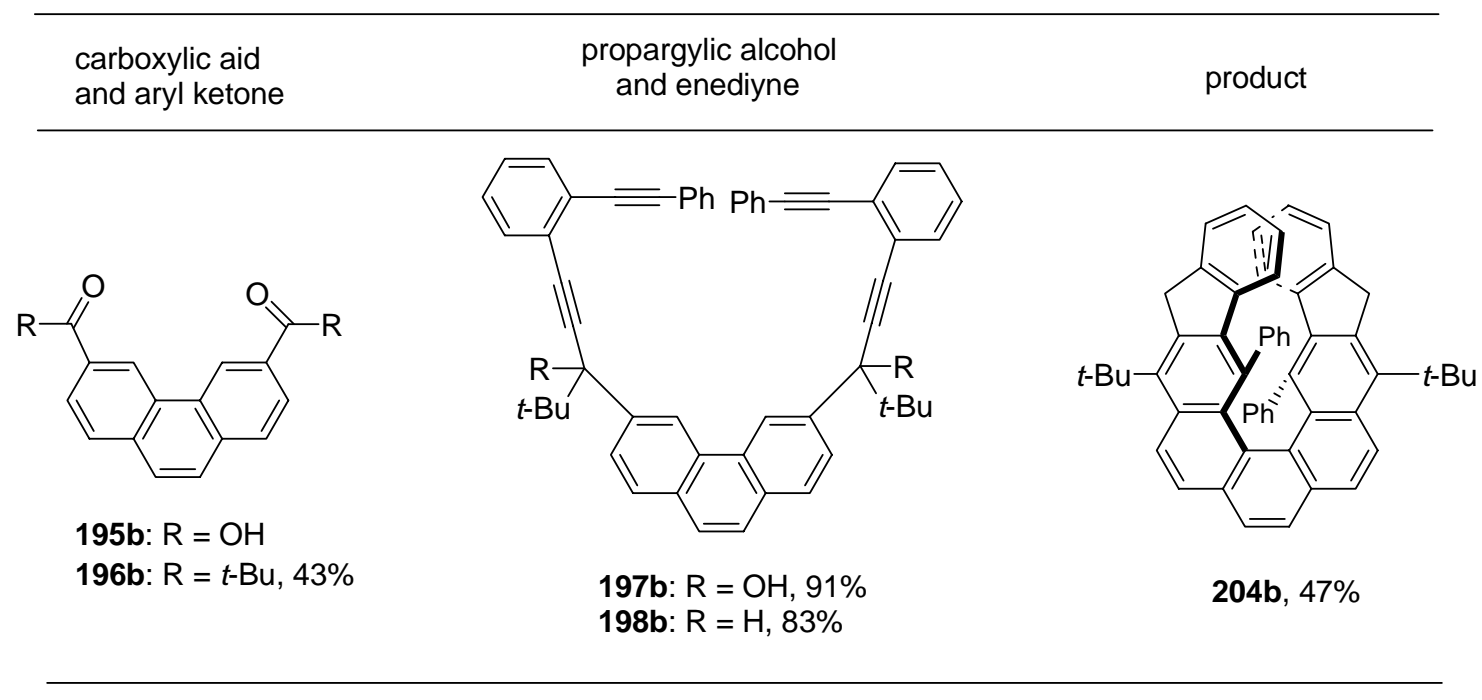

\subsection{Structure Analysis of 204a and 204b}

It is worth noting that the intramolecular radical-radical coupling reactions derived from 200 and 202 prefer the $\alpha$-position of the naphthyl ring to produce 204a instead of the sterically less congested $\beta$-position. A similar preference could also account for the formation of the angularly fused $\mathbf{2 0 4 b}$, as observed in previous cases. ${ }^{17}$ The higher reactivity of the $\alpha$-position than the $\beta$-position of naphthalene and phenanthrene in homolytic addition may be responsible for the regioselectivity. ${ }^{57}$

The structure of 204a was unequivocally established by X-ray structure analysis. The ORTEP drawing of 204a is given in Figure 5 to illustrate the severity of structural distortion. Due to two phenyl substituents in the highly congested fjord region, the acute dihedral angle between the mean planes of the two benzene rings bearing the phenyl substituent is pronounced $59.9^{\circ}$ from planarity, which indicates an even more remarkable structure distortion, compared to the acute dihedral angle of benzo[ $c]$ phenanthrene at $27^{\circ} .{ }^{67}$

The ${ }^{1} \mathrm{H}$ NMR spectrum of 204a in $\mathrm{CDCl}_{3}$ exhibited a set of $\mathrm{AB}$ quartet at $\delta 4.09$ and $4.26(J=20.4 \mathrm{~Hz})$ from the diastereotopic methylene hydrogens on the five-membered rings, manifesting the presence of a helical twist.

The upfield-shift signal at $\delta 5.71$ (doublet) was attributable to the inner ortho hydrogens on the phenyl substituents, indicating that each of the phenyl substituents is essentially parallel to the benzene ring at the other end of the central aromatic system. Such 
an orientation places the inner ortho hydrogens in the shielding region of the induced aromatic ring current, but puts the outer ortho hydrogens in the deshielding region with a downfield signal at $\delta 7.89$. Such an orientation was also manifested by an upfield signal at $\delta$ 6.31 (doublet), attributable to the two aromatic hydrogens closest to the phenyl substituents as observed in previous case ${ }^{17}$.

The fact that two distinct signals were observed for the ortho hydrogens suggests that rotation of the phenyl groups is restricted on the NMR time scale. The signals of the ortho hydrogens observed at $\delta 7.89$ and 5.71 coalesced at ca. $120{ }^{\circ} \mathrm{C}$, corresponding to a rotational barrier of ca. $17.6 \mathrm{kcal} / \mathrm{mol}$.

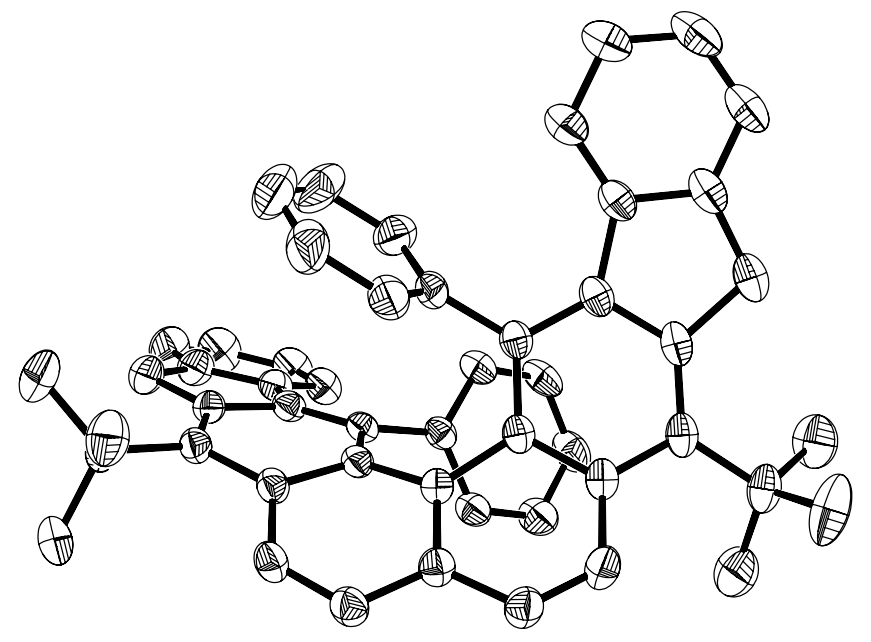

Figure 5. ORTEP drawing of the crystal structure of 204a with hydrogen atoms omitted for clarity.

The distorted structure of 204b was also indicated by an AB pattern on the ${ }^{1} \mathrm{H}$ NMR spectrum from the diastereotopic methylene hydrogens on the five-membered rings and conformed by X-ray structure analysis (Figure 6). The X-ray structure of 204b showed that the acute dihedral angle between the mean planes of the two benzene rings bearing the phenyl substitutes is $57.8^{\circ}$, smaller than that of 204a, still much larger than the value of $30^{\circ}$ for [5] helicene. ${ }^{68}$

The ${ }^{1} \mathrm{H}$ NMR spectrum of 204b in $\mathrm{CDCl}_{3}$ recorded on a $600 \mathrm{MHz} \mathrm{NMR}$ spectrometer at $25{ }^{\circ} \mathrm{C}$ showed two broad humps at $\delta 6.50$ and 5.58 , attributable to the ortho 
hydrogens on the phenyl substituents. The coalescence temperature for the ortho hydrogens is $75{ }^{\circ} \mathrm{C}$, corresponding to a rotation barrier of $16.3 \mathrm{kcal} / \mathrm{mol}$, which is lower than that of 204a. The observations of 204b with a smaller acute dihedral angle and a lower rotation barrier of the phenyl substituents than those of 204a suggests that 204b is less strained, since 204b has a larger skeletal framework between the interfering phenyl substituents over which to distribute the distortion created by the phenyl overcrowding.

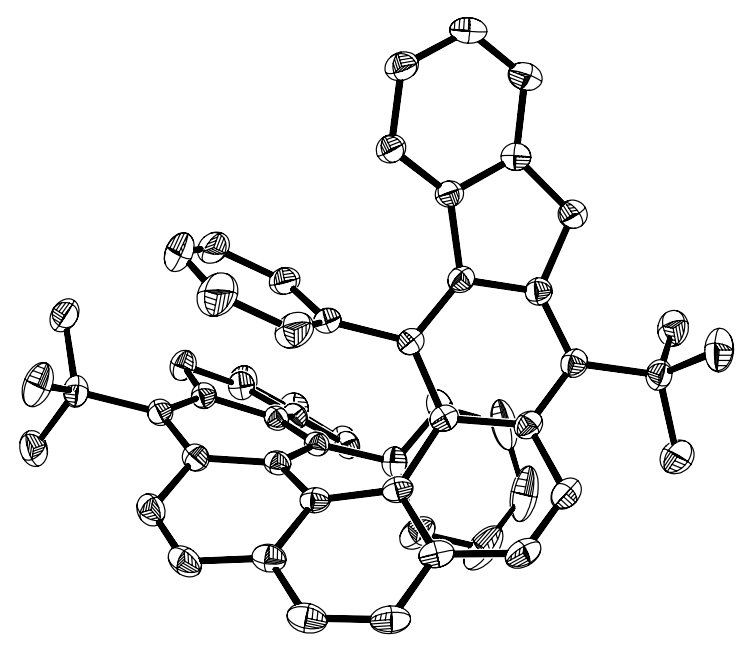

Figure 6. ORTEP drawing of the crystal structure of 204b with hydrogen atoms omitted for clarity.

\section{Conclusions}

The diindeno-fused benzo $[c]$ phenanthrene 204a and dibenzo $[c, g]$ phenanthrene 204b, bearing two phenyl substitutents at the overcrowded region, were readily synthesized via the Schmittel cyclization reaction of the corresponding benzannulated enyne-allenes 198a and 198b respectively. The structures of 204a and 204b with a helical twist were established by X-ray structure analysis and the rotation of the phenyl substitutents is restricted. 


\section{Chapter VII}

\section{Experimental Section}

All reactions were conducted in oven-dried $\left(120^{\circ} \mathrm{C}\right)$ glassware under a nitrogen atmosphere. Diethyl ether and tetrahydrofuran (THF) were distilled from benzophenone ketyl, toluene and $p$-xylene were distilled over $\mathrm{CaH}_{2}$ prior to use. Melting points were uncorrected. ${ }^{1} \mathrm{H}(270 \mathrm{MHz})$ and ${ }^{13} \mathrm{C}(67.9 \mathrm{MHz})$ NMR spectra were recorded in $\mathrm{CDCl}_{3}$ using $\mathrm{CHCl}_{3}\left({ }^{1} \mathrm{H} \delta\right.$ 7.26) and $\mathrm{CDCl}_{3}\left({ }^{13} \mathrm{C} \delta 77.0\right)$ as internal standards unless otherwise indicated. IR spectra were taken on Perkin-Elmer LX10-8704 Spectrum One FT-IR spectrometer. Mass spectra and high resolution mass spectra were obtained on Hewlett Packard 5970B GC/MSD instrument at $70 \mathrm{eV}$, VG 7070 by DEI, VG-ZAB by FAB and DE-STR by MALDI.

$n$-Butyllithium $(2.5 \mathrm{M})$ in hexanes, $t$-butyllithium $(1.7 \mathrm{M})$ in pentane, lithium diisopropylamide (LDA, $2.0 \mathrm{M})$ in $\mathrm{THF} / n$-heptane, $\mathrm{CuBr} \cdot \mathrm{SMe}_{2}$, triethylsilane, trifluoroacetic acid, potassium $t$-butoxide $(1.0 \mathrm{M})$ in 2-methyl-2-propanol, potassium $t$-butoxide, 2-methyl-2-propanol, triethylamine, phenylacetylene, (trimethylsilyl)acetylene, $\mathrm{Pd}\left(\mathrm{PPh}_{3}\right)_{2} \mathrm{Cl}_{2}$, copper(I) iodide, 2,2-dimethylpropiophenone (147), 2-naphthnyl chloride (159a), 3-acetylphenanthrene, 2-(bromomethyl)naphthalene (161), triphenylphosphine, and methyl 4-formylbenzoate (162) were purchased from chemical suppliers and were used as received.

1-Ethynyl-2-(phenylethynyl)benzene $(\mathbf{4 6})^{17}, \quad 2,2$-dimethyl-1,3-indandione $(\mathbf{1 1 1}){ }^{34}$ 3-phenanthrenecarboxylic acid (159b), ${ }^{53}$ 1,5-dibromo-2,4-diiodobenzene $\quad(\mathbf{1 8 6}){ }^{60}$ 1-ethynyl-4-(1,1,3,3-tetramethylbutyl)benzene (187b), ${ }^{33}$ 2,7-naphthalenedicarboxylic acid (195a), 3,6-phenanthrenedicarboxylic acid (195b), ${ }^{66}$ were prepared according to the reported procedures.

Propargylic Diols 112. To a solution of 1-ethynyl-2-(phenylethynyl)benzene $(0.368 \mathrm{~g}, 1.82$ mmol) in $10 \mathrm{~mL}$ THF was added $0.73 \mathrm{~mL}$ of a $2.5 \mathrm{M}$ solution of $n$-butyllithium $(1.82 \mathrm{mmol})$ at $0{ }^{\circ} \mathrm{C}$. The reaction mixture was then allowed to warm to rt. After $30 \mathrm{~min}$, a solution of 2,2-dimethyl-1,3-indandione (111, $0.138 \mathrm{~g}, 0.792 \mathrm{mmol})$ in $10 \mathrm{~mL}$ THF was added via cannula. After an additional $12 \mathrm{~h}$ of stirring at $\mathrm{rt}$, the reaction mixture was quenched with 10 $\mathrm{mL}$ of water and extracted with diethyl ether. The organic layer was separated, washed with 
water, dried over sodium sulfate, and concentrated to furnish a light yellow residue. The residue was purified by flash column chromatography (silica gel/50\% methylene chloride in hexanes) to afford trans-112a $(0.233 \mathrm{~g}, 51 \%)$ and cis-112b $(0.040 \mathrm{~g}, 9 \%)$ as white solids. trans-Diol 112a: $\mathrm{mp} 63-65{ }^{\circ} \mathrm{C}$; IR 3440, 2217, $755 \mathrm{~cm}^{-1} ;{ }^{1} \mathrm{H}$ NMR $\delta 7.68-7.65(4 \mathrm{H}, \mathrm{m})$, 7.56-7.48 (4 H, m), 7.46-7.41 (4 H, m), 7.35-7.23 (10 H, m), $2.71(2 \mathrm{H}, \mathrm{s}), 1.42(6 \mathrm{H}, \mathrm{s})$; ${ }^{13} \mathrm{C}$ NMR $\delta 143.6,132.2,132.0,131.7,129.6,128.4,128.3,128.2,127.9,125.8,124.6$, 124.3, 122.9, 93.4, 87.9, 86.5, 80.2, 57.4, 20.1; cis-Diol 112b: mp 59-61 ${ }^{\circ} \mathrm{C}$; IR 3423, 755 $\mathrm{cm}^{-1} ;{ }^{1} \mathrm{H}$ NMR $\delta 7.78-7.74(4 \mathrm{H}, \mathrm{m}), 7.60-7.53$ (4 H, m), 7.45-7.41 (4 H, m), 7.35-7.19 (10 H, m), $3.18(2 \mathrm{H}, \mathrm{s}), 1.52$ (3 H, s), 1.29 (3 H, s); ${ }^{13} \mathrm{C}$ NMR $\delta 144.6,132.4,132.1,131.7$, $129.7,128.41,128.38,128.3,127.9,126.1,124.8,124.7,122.9,93.4,90.9,88.0,85.9,81.8$, $56.3,25.8,15.7$.

4H-Cyclopenta[def]phenanthrene 116. To trans-7 $(0.208 \mathrm{~g}, 0.361 \mathrm{mmol})$ in $10 \mathrm{~mL}$ of THF at $0{ }^{\circ} \mathrm{C}$ was added via cannula a solution of thionyl chloride $(0.215 \mathrm{~g}, 1.803 \mathrm{mmol})$ and anhydrous pyridine $(0.285 \mathrm{~g}, 3.61 \mathrm{mmol})$ in $5 \mathrm{~mL}$ of THF. The reaction mixture was allowed to warm to rt. After an additional $8 \mathrm{~h}, 10 \mathrm{~mL}$ of water was introduced, and the reaction mixture was extracted with $20 \mathrm{~mL}$ of methylene chloride. The combined organic extracts were washed with water, dried over sodium sulfate, and concentrated to furnish the crude dichloride 115. To a flask containing AIBN $(0.0059 \mathrm{~g}, 0.0361 \mathrm{mmol})$ were added a solution of the crude 115 in $20 \mathrm{~mL}$ of benzene and tributyltin hydride $(0.29 \mathrm{~mL}, 1.02 \mathrm{mmol})$. The reaction mixture was heated under reflux for $18 \mathrm{~h}$. After the reaction mixture was allowed to cool to $\mathrm{rt}, 10 \mathrm{~mL}$ of a $10 \%$ aqueous potassium fluoride solution was introduced. The mixture was stirred for an additional $2 \mathrm{~h}$ and filtered. The organic layer was separated, washed with water, dried over sodium sulfate, and concentrated to give a brown solid residue. The residue was purified by flash column chromatography ( silica gel/50\% methylene chloride in hexanes) to afford $116(0.084 \mathrm{~g}, 43 \%)$ as a yellow solid: compound becomes black without melting at $289{ }^{\circ} \mathrm{C}$; IR 1599, 1459, 1402, 747, $700 \mathrm{~cm}^{-1} ;{ }^{1} \mathrm{H}$ NMR $\delta 7.66-7.48(12 \mathrm{H}, \mathrm{m}), 7.41(2 \mathrm{H}, \mathrm{s})$, $7.25(2 \mathrm{H}, \mathrm{t}, J=7.3 \mathrm{~Hz}), 7.07(2 \mathrm{H}, \mathrm{t}, J=7.5 \mathrm{~Hz}), 6.74(2 \mathrm{H}, \mathrm{d}, J=7.7 \mathrm{~Hz}), 4.33(4 \mathrm{H}, \mathrm{s})$, 2.02 (6 H, s); ${ }^{13} \mathrm{C}$ NMR $\delta 145.9,143.8,142.1,139.2,138.6,134.9,134.7,131.8,130.1$, $128.9,127.6,126.9,126.5,126.4,124.9,123.7,123.4,51.1,33.8,23.3 ;$ MS $m / z 546\left(\mathrm{M}^{+}\right)$, 
531, 516; HRMS calcd for $\mathrm{C}_{43} \mathrm{H}_{30}\left(\mathrm{M}^{+}\right)$546.2348, found 546.2367.

Benzo[c]phenanthrene-2-carboxylic acid (159c). A suspension of $0.324 \mathrm{~g}$ of 164 (1.08 $\mathrm{mmol}$ ) and $1.00 \mathrm{~g}$ of sodium hydroxide in $20 \mathrm{~mL}$ of ethanol and $20 \mathrm{~mL}$ of water was heated under reflux for $3 \mathrm{~h}$. The solution was concentrated to reduce the volume of the solution to ca. $15 \mathrm{~mL}$ and then extracted with $20 \mathrm{~mL}$ of diethyl ether. The aqueous layer was acidified with a $10 \%$ aqueous hydrochloric acid solution solution to produce a white precipitate. The white precipitate was filtered and then washed with a $1 \mathrm{M}$ aqueous hydrochloric acid solution solution, water, and hexanes. The product was pumped to dryness in vacuo to afford $0.282 \mathrm{~g}$ of 159c (1.03 mmol, 96\%) as a white solid: IR 3300-2500 (br), $1686 \mathrm{~cm}^{-1}$; ${ }^{1} \mathrm{H}$ NMR $\delta\left(600 \mathrm{MHz}, \mathrm{CDCl}_{3}\right) 9.99(1 \mathrm{H}, \mathrm{s}), 9.12(1 \mathrm{H}, \mathrm{d}, J=8.4 \mathrm{~Hz}), 8.30(1 \mathrm{H}, \mathrm{d}, J=7.8 \mathrm{~Hz}), 8.11$ $(1 \mathrm{H}, \mathrm{d}, J=8.4 \mathrm{~Hz}), 8.07(1 \mathrm{H}, \mathrm{d}, J=7.8 \mathrm{~Hz}), 7.99-7.95(3 \mathrm{H}, \mathrm{m}), 7.86(1 \mathrm{H}, \mathrm{d}, J=8.4 \mathrm{~Hz})$, $7.81(1 \mathrm{H}, \mathrm{t}, J=7.5 \mathrm{~Hz}), 7.70(1 \mathrm{H}, \mathrm{t}, J=7.5 \mathrm{~Hz}) ;{ }^{13} \mathrm{C} \mathrm{NMR}\left(600 \mathrm{MHz}, 1 \% \mathrm{DMSO}-d_{6}\right.$ in $\left.\mathrm{CDCl}_{3}\right) \delta 170.6,136.3133 .7,131.27,131.23,130.1,129.60,129.57,128.7,128.6,128.18$, $128.05,127.9,126.98,126.92,126.90,126.6,126.3,125.9$.

Aryl Ketone 160a. The following procedure is representative for the preparation of the aryl ketones. To a suspension of $1.36 \mathrm{~g}$ of $\mathrm{CuBr} \cdot \mathrm{SMe}_{2}(6.63 \mathrm{mmol})$ in $40 \mathrm{~mL}$ of THF was added $3.9 \mathrm{~mL}$ of a $1.7 \mathrm{M}$ solution of $t$-butyllithium $(6.63 \mathrm{mmol})$ in pentane at $-50{ }^{\circ} \mathrm{C}$. After $30 \mathrm{~min}$ of stirring, a solution of $1.05 \mathrm{~g}$ of 2-naphthnyl chloride (159a, $5.53 \mathrm{mmol})$ in $15 \mathrm{~mL}$ of THF was introduced dropwise via cannula. After an additional $4 \mathrm{~h}$ at $-50{ }^{\circ} \mathrm{C}$, the reaction mixture was allowed to warm to room temperature and treated with $20 \mathrm{~mL}$ of a saturated aqueous ammonium chloride solution. The organic layer was separated, and the aqueous layer was back extracted with diethyl ether. The combined organic layers were washed with brine and water, dried over sodium sulfate, and concentrated. Purification by flash column chromatography (silica gel/20\% diethyl ether in hexanes) afforded $1.17 \mathrm{~g}$ of 160a (5.53 mmol, 100\%) as a white solid: $\mathrm{mp} 54-56{ }^{\circ} \mathrm{C}$; IR 1670, 1164, 1122, $760 \mathrm{~cm}^{-1} ;{ }^{1} \mathrm{H}$ NMR $\delta$ $8.23(1 \mathrm{H}, \mathrm{s}), 7.94-7.76(4 \mathrm{H}, \mathrm{m}), 7.60-7.50(2 \mathrm{H}, \mathrm{m}), 1.43(9 \mathrm{H}, \mathrm{s}) ;{ }^{13} \mathrm{C} \mathrm{NMR} \delta 209.0$, 135.7, 134.2, 132.3, 129.1, 128.4, 127.7, 127.6, 126.6, 124.8, 44.3, 28.2; MS $m / z 212\left(\mathrm{M}^{+}\right)$, $155,127$.

Aryl Ketone 160b. To a flask containing $0.500 \mathrm{~g}(2.25 \mathrm{mmol})$ of 3-phenanthrenecarboxylic 
acid (159b) was introduced $39 \mathrm{~mL}$ of thionyl chloride. The reaction mixture was heated under reflux for $12 \mathrm{~h}$. The excess thionyl chloride was removed in vacuo to furnish the crude 3-phenanthrenecarbonyl chloride. The same procedure was then repeated as described for 160a except that $0.562 \mathrm{~g}$ of $\mathrm{CuBr} \cdot \mathrm{SMe}_{2}(2.71 \mathrm{mmol})$ and $1.6 \mathrm{~mL}$ of a $1.7 \mathrm{M}$ solution of $t$-butyllithium $(2.71 \mathrm{mmol})$ in pentane were used to afford $0.558 \mathrm{~g}$ of $\mathbf{1 6 0 b}(2.13 \mathrm{mmol}, 95 \%)$ as an orange solid: mp 57-59 ${ }^{\circ} \mathrm{C}$; IR 1667, $842 \mathrm{~cm}^{-1}$; ${ }^{1} \mathrm{H}$ NMR $\delta 9.13(1 \mathrm{H}, \mathrm{s}), 8.64(1 \mathrm{H}, \mathrm{d}$, $J=7.9 \mathrm{~Hz}), 7.93(1 \mathrm{H}, \mathrm{dd}, J=8.2,1.4 \mathrm{~Hz}), 7.76(2 \mathrm{H}, \mathrm{t}, J=8.7 \mathrm{~Hz}), 7.67-7.51(4 \mathrm{H}, \mathrm{m})$, 1.50 (9 H, s); ${ }^{13} \mathrm{C}$ NMR $\delta 209.0,136.2,133.4,132.2,130.5,129.6,128.85,128.78,128.1$, 127.09, 127.03, 126.2, 125.6, 123.2, 122.6, 44.4, 28.3; MS m/z $262\left(\mathrm{M}^{+}\right), 205,177$.

Aryl Ketone 160c. The same procedure was repeated as described for 160b except that $0.264 \mathrm{~g}(0.97 \mathrm{mmol})$ of benzo[c]phenanthrene-2-carboxylic acid (159c) was heated with 17 $\mathrm{mL}$ of thionyl chloride under reflux for $12 \mathrm{~h}$ to furnish the crude benzo $[c]$ phenanthrene-2-carbonyl chloride. The acid chloride was treated with $t$-butylcopper, prepared from $0.241 \mathrm{~g}$ of $\mathrm{CuBr} \cdot \mathrm{SMe}_{2}(1.16 \mathrm{mmol})$ and $0.68 \mathrm{~mL}$ of a $1.7 \mathrm{M}$ solution of $t$-butyllithium $(1.16 \mathrm{mmol})$ in pentane, to afford $0.193 \mathrm{~g}$ of 160c $(0.62 \mathrm{mmol}, 64 \%)$ as an orange solid: $\mathrm{mp} 68-70{ }^{\circ} \mathrm{C}$; IR 1668, $848 \mathrm{~cm}^{-1} ;{ }^{1} \mathrm{H}$ NMR $\delta 9.57(1 \mathrm{H}, \mathrm{s}), 9.03(1 \mathrm{H}, \mathrm{d}, J=$ $8.4 \mathrm{~Hz}), 8.07-7.97(3 \mathrm{H}, \mathrm{m}), 7.94(1 \mathrm{H}, \mathrm{d}, J=8.4 \mathrm{~Hz}), 7.90(2 \mathrm{H}, \mathrm{s}), 7.84(1 \mathrm{H}, \mathrm{d}, J=8.6$ $\mathrm{Hz}), 7.77-7.63$ (2 H, m), 1.49 (9 H, s); ${ }^{13} \mathrm{C}$ NMR $\delta 208.8,135.4,134.6,133.6,131.2,129.9$, $129.2,128.73,128.66128 .5,128.2,127.9,127.7,126.8,126.7,126.5,126.2,125.1,44.2$, 28.2; MS m/z $255\left(\mathrm{M}^{+}\right), 226,57$.

Ethyl 4-[2-(2-Naphthalenyl)ethynyl]benzoate (163). A suspension of $1.44 \mathrm{~g}$ of 2-(bromomethyl)naphthalene $(\mathbf{1 6 1}, 6.25 \mathrm{mmol})$ and $1.64 \mathrm{~g}$ of triphenylphosphine $(6.25$ mmol) in $15 \mathrm{~mL}$ of $\mathrm{N}, \mathrm{N}$-dimethylformamide was heated at $150{ }^{\circ} \mathrm{C}$ for $30 \mathrm{~min}$. After the solution was cooled to rt, $1.03 \mathrm{~g}$ of methyl 4-formylbenzoate $(\mathbf{1 6 2}, 6.25 \mathrm{mmol})$ and lithium ethoxide, prepared from treatment of $10 \mathrm{~mL}$ of ethanol with $5.6 \mathrm{~mL}$ of a $2.5 \mathrm{M}$ solution of $n$-butyllithium (14.0 mmol) in hexanes, were added. The resulting suspension was stirred at $\mathrm{rt}$ for $3.5 \mathrm{~h}$. The reaction mixture was then diluted with $30 \mathrm{~mL}$ of diethyl ether and washed successively with $30 \mathrm{~mL}$ of a $10 \%$ aqueous hydrochloric acid solution, brine, and water. The organic layer was separated, dried over sodium sulfate, and concentrated. Purification by 
flash column chromatography (silica gel/50\% methylene chloride in hexanes) afforded 1.51 $\mathrm{g}$ of $163(5.0 \mathrm{mmol}, 80 \%$, a mixture of the trans and cis isomers; trans:cis $=5.5: 4.5)$ as a white solid: ${ }^{1} \mathrm{H}$ NMR $\delta 8.07(1 \mathrm{H}, \mathrm{d}, J=8.2 \mathrm{~Hz}), 7.94-7.59(6 \mathrm{H}, \mathrm{m}), 7.53-7.43(2 \mathrm{H}, \mathrm{m})$, $7.38(0.55 \mathrm{H}, \mathrm{d}, J=16.3 \mathrm{~Hz}), 7.36-7.29(2 \mathrm{H}, \mathrm{m}), 7.25(0.55 \mathrm{H}, \mathrm{d}, J=16.3 \mathrm{~Hz}), 6.87$ (0.45 $\mathrm{H}, \mathrm{d}, J=12.1 \mathrm{~Hz}), 6.70(0.45 \mathrm{H}, \mathrm{d}, J=12.1 \mathrm{~Hz}), 4.41(1.1 \mathrm{H}, \mathrm{q}, J=7.2 \mathrm{~Hz}), 4.37(0.9 \mathrm{H}, \mathrm{q}$, $J=7.2 \mathrm{~Hz}), 1.43(1.7 \mathrm{H}, \mathrm{t}, J=7.2 \mathrm{~Hz}), 1.38(1.3 \mathrm{H}, \mathrm{t}, J=7.2 \mathrm{~Hz}) ;{ }^{13} \mathrm{C}$ NMR $\delta 166.4,141.9$, $141.7,134.2$, 133.6, 133.3, 133.2, 132.6, 132.1, 131.1, 130.0, 129.51, 129.45, 129.2, 129.0, $128.9,128.4,128.13,128.07,127.9,127.8,127.7,127.6,127.3,126.6,126.4,126.24,126.19$, $126.1,123.3,60.9,14.3$.

Ethyl Benzo[c]phenanthrene-2-carboxylate (164). A solution of $0.245 \mathrm{~g}$ of $163(0.811$ $\mathrm{mmol}), 0.204 \mathrm{~g}$ of iodine $(1.27 \mathrm{mmol})$, and $8.5 \mathrm{~mL}$ of propylene oxide $(120 \mathrm{mmol})$ in $1.5 \mathrm{~L}$ of benzene was photolyzed for $72 \mathrm{~h}$ in a Rayonet photochemical apparatus equipped with sixteen of the 254-nm mercury lamps. The reaction mixture was then concentrated to reduce the volume of the reaction mixture to $100 \mathrm{~mL}$. The concentrated solution was washed with a $15 \%$ aqueous sodium thiosulfate solution, brine, and water. The organic layer was separated, dried over sodium sulfate, and concentrated. Four separate runs of similar scales followed by purification of the resulting adducts by flash column chromatography (silica gel $/ 5 \%$ diethyl ether in hexanes) converted $0.984 \mathrm{~g}(3.26 \mathrm{mmol})$ of 163 to $0.728 \mathrm{~g}(2.41 \mathrm{mmol}, 74 \%)$ of 164 as a white solid: IR 1710, $1268 \mathrm{~cm}^{-1} ;{ }^{1} \mathrm{H}$ NMR $\delta 9.89(1 \mathrm{H}, \mathrm{s}), 9.11(1 \mathrm{H}, \mathrm{d}, J=8.4 \mathrm{~Hz}), 8.23$ (1 H, dd, $J=8.4,1.5 \mathrm{~Hz}), 8.06-8.01(2 \mathrm{H}, \mathrm{m}), 7.95-7.89(3 \mathrm{H}, \mathrm{m}), 7.81(1 \mathrm{H}, \mathrm{d}, J=8.4 \mathrm{~Hz})$, $7.77(1 \mathrm{H}, \mathrm{td}, J=8.4,1.5 \mathrm{~Hz}), 7.67(1 \mathrm{H}, \mathrm{t}, J=6.7 \mathrm{~Hz}), 4.51(2 \mathrm{H}, \mathrm{q}, J=7.2 \mathrm{~Hz}), 1.49(3 \mathrm{H}, \mathrm{t}$, $J=7.2 \mathrm{~Hz}) ;{ }^{13} \mathrm{C}$ NMR $\delta 167.0,135.8,133.6,131.1,130.5,130.0,129.4,129.2,128.6,128.5$, $128.0,127.86,127.80,127.7,126.8,126.6,126.5,126.2,125.5,61.1,14.4$.

Propargylic Alcohol 165a. The following procedure is representative for the preparation of the propargylic alcohols. A solution of $0.264 \mathrm{~g}$ of 160a $(1.25 \mathrm{mmol})$ in $20 \mathrm{~mL}$ of THF was introduced via cannula to the solution of $\mathbf{4 6}$ in $10 \mathrm{~mL}$ of THF, prepared from $0.302 \mathrm{~g}$ of 1-ethynyl-2-(phenylethynyl)benzene $(1.50 \mathrm{mmol})$ and $0.60 \mathrm{~mL}$ of a $2.5 \mathrm{M}$ solution of $n$-butyllithium $(1.50 \mathrm{mmol})$ in hexanes at $0{ }^{\circ} \mathrm{C}$ with $30 \mathrm{~min}$ of stirring, then the reaction mixture was allowed to warm to rt. After an additional $2 \mathrm{~h}, 20 \mathrm{~mL}$ of water was introduced, 
and the reaction mixture was extracted with diethyl ether. The combined organic extracts were washed with brine and water, dried over sodium sulfate, and concentrated. Purification by flash column chromatography (silica ge1/20\% diethyl ether in hexanes) afforded $0.496 \mathrm{~g}$ of 165a (1.20 mmol, 96\%) as a white solid: IR 3574, $1494 \mathrm{~cm}^{-1} ;{ }^{1} \mathrm{H}$ NMR $\delta 8.25(1 \mathrm{H}, \mathrm{d}, J=$ $1.2 \mathrm{~Hz}), 7.96(1 \mathrm{H}, \mathrm{dd}, J=8.7,1.7 \mathrm{~Hz}), 7.83-7.81(2 \mathrm{H}, \mathrm{m}), 7.71(1 \mathrm{H}, \mathrm{d}, J=8.9 \mathrm{~Hz})$, 7.63-7.56 (2 H, m), 7.50-7.40 (4 H, m), 7.36-7.17 (5 H, m), $2.65(1 \mathrm{H}, \mathrm{s}), 1.20(9 \mathrm{H}, \mathrm{s}) ;{ }^{13} \mathrm{C}$ NMR $\delta 139.7,132.6,132.4,132.21,132.15,131.6,128.38,128.34,128.2,127.9,127.3$, $126.5,126.4,126.2,125.9125 .8,125.0,122.9,96.2,93.3,88.2,84.7,79.6,40.0,25.6$.

Propargylic Alcohol 165b. The same procedure was repeated as described for 165a except that $0.558 \mathrm{~g}$ of $160 \mathrm{~b}(2.13 \mathrm{mmol})$ was treated with the solution of 46 in $20 \mathrm{~mL}$ of THF, prepared from $0.516 \mathrm{~g}$ of 1-ethynyl-2-(phenylethynyl)benzene $(2.56 \mathrm{mmol})$ and $1.0 \mathrm{~mL}$ of a $2.5 \mathrm{M}$ solution of $n$-butyllithium $(2.5 \mathrm{mmol})$ in hexanes, to afford $0.931 \mathrm{~g}$ of $\mathbf{1 6 5 b}$ (2.01 mmol, 94\%) as a white solid: IR 3546, 2213, $753 \mathrm{~cm}^{-1} ;{ }^{1} \mathrm{H}$ NMR $\delta 9.32(1 \mathrm{H}, \mathrm{s}), 8.96(1 \mathrm{H}, \mathrm{d}$, $J=7.7 \mathrm{~Hz}), 8.25(1 \mathrm{H}, \mathrm{d}, J=8.2 \mathrm{~Hz}), 7.99(1 \mathrm{H}, \mathrm{d}, J=6.9 \mathrm{~Hz}), 7.90-7.70(7 \mathrm{H}, \mathrm{m}), 7.60(2$ $\mathrm{H}, \mathrm{d}, J=7.4 \mathrm{~Hz}), 7.44-7.28(5 \mathrm{H}, \mathrm{m}), 3.17(1 \mathrm{H}, \mathrm{s}), 1.44(9 \mathrm{H}, \mathrm{s}) ;{ }^{13} \mathrm{C}$ NMR $\delta 140.3,132.14$, $132.10,131.9,131.5,131.1,130.4,129.1,128.4,128.2,128.03,127.98,127.86,127.0,126.9$, $126.7,126.4,126.3,125.8,124.9,122.75,122.68,121.4,96.4,93.4,88.3,84.8,79.8,39.9$, 25.6 .

Propargylic Alcohol 165c. The same procedure was repeated as described for 165a except that $0.102 \mathrm{~g}$ of $160 \mathrm{c}(0.33 \mathrm{mmol})$ was treated with the solution of 46 in $10 \mathrm{~mL}$ of $\mathrm{THF}$, prepared from $0.079 \mathrm{~g}$ of 1-ethynyl-2-(phenylethynyl)benzene $(0.39 \mathrm{mmol})$ and $0.16 \mathrm{~mL}$ of a 2.5 M solution of $n$-butyllithium in hexanes, to afford $0.146 \mathrm{~g}$ of $165 \mathrm{c}(0.28 \mathrm{mmol}, 87 \%)$ as a white solid: IR 3556, 2217, $730 \mathrm{~cm}^{-1}$; ${ }^{1} \mathrm{H}$ NMR $\delta 9.58(1 \mathrm{H}, \mathrm{s}), 9.23(1 \mathrm{H}, \mathrm{d}, J=8.4 \mathrm{~Hz})$, $8.09(1 \mathrm{H}, \mathrm{dd}, J=8.4,1.7 \mathrm{~Hz}), 8.01(1 \mathrm{H}, \mathrm{d}, J=7.9 \mathrm{~Hz}), 7.95-7.82(5 \mathrm{H}, \mathrm{m}), 7.67-7.61(2 \mathrm{H}$, m), $7.57(1 \mathrm{H}, \mathrm{t}, J=7.4 \mathrm{~Hz}), 7.44-7.32(5 \mathrm{H}, \mathrm{m}), 7.28-7.12(3 \mathrm{H}, \mathrm{m}), 2.74(1 \mathrm{H}, \mathrm{s}), 1.24$ (9 $\mathrm{H}, \mathrm{s}) ;{ }^{13} \mathrm{C}$ NMR $\delta 140.1,133.4,132.7,132.3,132.1,131.5,131.1,130.2,129.1,128.4,128.3$, $128.1,128.0,127.9,127.6,127.4,127.07,126.96,126.91,126.7,126.2,126.1,125.9,125.8$, $125.1,122.7,96.5,93.4,88.3,84.9,80.0,40.2,25.7$.

Benzannulated Enediyne 166a. The following procedure is representative for the 
preparation of the benzannulated enediynes. To a solution of $0.494 \mathrm{~g}$ of 165a $(1.19 \mathrm{mmol})$ and $0.208 \mathrm{~g}$ of triethylsilane $(1.79 \mathrm{mmol})$ in $20 \mathrm{~mL}$ of methylene chloride was added 0.37 $\mathrm{mL}$ of trifluoroacetic acid $(0.543 \mathrm{~g}, 4.77 \mathrm{mmol})$. After $10 \mathrm{~min}$ of stirring at $\mathrm{rt}$, a solution of $0.322 \mathrm{~g}$ of sodium carbonate $(3.04 \mathrm{mmol})$ in $15 \mathrm{~mL}$ of water was introduced, and the reaction mixture was extracted with diethyl ether. The combined organic extracts were washed with brine and water, dried over sodium sulfate, and concentrated. Purification by flash column chromatography (silica gel/5\% diethyl ether in hexanes) afforded $0.466 \mathrm{~g}$ of 166a (1.17 mmol, 98\%) as a yellow solid: $\mathrm{mp} 90-92{ }^{\circ} \mathrm{C}$; IR 2215, 1494, $783 \mathrm{~cm}^{-1} ;{ }^{1} \mathrm{H}$ NMR $\delta 7.97(1 \mathrm{H}$, s), 7.90-7.82 (2 H, m), 7.81-7.72 (2 H, m), 7.69-7.61 (2 H, m), 7.54-7.46 (4 H, m), 7.38-7.31 (3 H, m), $7.24(2 \mathrm{H}, \mathrm{t}, J=7.3 \mathrm{~Hz}), 4.01(1 \mathrm{H}, \mathrm{s}), 1.21(9 \mathrm{H}, \mathrm{s}) ;{ }^{13} \mathrm{C} \mathrm{NMR} \delta 136.8$, 133.0, 132.4, 132.10, 132.04, 131.6, 128.3, 128.14, 128.07, 127.8, 127.45, 127.38, 127.0, 126.3, 125.8, 125.7, 125.5, 123.2, 95.6, 92.9, 88.6, 82.7, 50.8, 35.8, 27.9; MS m/z $398\left(\mathrm{M}^{+}\right)$, $355,270$.

Benzannulated Enediyne 166b. The same procedure was repeated as described for 166a except that $0.114 \mathrm{~g}$ of $\mathbf{1 6 5 b}(0.25 \mathrm{mmol})$ was treated with $0.043 \mathrm{~g}$ of triethylsilane $(0.37$ $\mathrm{mmol})$ and $0.8 \mathrm{~mL}$ of trifluoroacetic acid $(0.99 \mathrm{mmol})$ in $10 \mathrm{~mL}$ methylene chloride to afford $0.107 \mathrm{~g}$ of 166b (0.24 mmol, 98\%) as a yellow solid: IR 2214, 1493, 842, $756 \mathrm{~cm}^{-1} ;{ }^{1} \mathrm{H}$ NMR $\delta 8.90(2 \mathrm{H}, \mathrm{m}), 8.04-7.97(1 \mathrm{H}, \mathrm{m}), 7.94-7.81(4 \mathrm{H}, \mathrm{m}), 7.77-7.69$ (4 H, m), 7.55 (2 $\mathrm{H}, \mathrm{d}, J=6.9 \mathrm{~Hz}), 7.44-7.22(5 \mathrm{H}, \mathrm{m}), 4.18(1 \mathrm{H}, \mathrm{s}), 1.35(9 \mathrm{H}, \mathrm{s}) ;{ }^{13} \mathrm{C}$ NMR $\delta 137.6,132.1$, $132.0,131.6,130.8,130.2,129.7,128.5,128.4,128.1,128.0,127.9,127.8,127.4,126.53$, $126.50,126.4,126.2,125.7,123.5,123.1,122.6,95.7,93.0,88.6,82.8,51.1,35.7,27.9 ; \mathrm{MS}$ $m / z 448\left(\mathrm{M}^{+}\right), 391,207$.

Benzannulated Enediyne 166c. The same procedure was repeated as described for 166a except that $0.140 \mathrm{~g}$ of 165c $(0.27 \mathrm{mmol})$ was treated with $0.048 \mathrm{~g}$ of triethylsilane $(0.41$ $\mathrm{mmol})$ and $0.90 \mathrm{~mL}$ of trifluoroacetic acid $(1.08 \mathrm{mmol})$ in $10 \mathrm{~mL}$ methylene chloride to afford $0.121 \mathrm{~g}$ of 166c $(0.24 \mathrm{mmol}, 89 \%)$ as a yellow solid: IR $2217,844 \mathrm{~cm}^{-1} ;{ }^{1} \mathrm{H}$ NMR $\delta$ 9.23-9.17 (2 H, m), 8.01 (1 H, $J=7.9 \mathrm{~Hz}), 7.93-7.75$ (6 H, m). 7.63-7.54 (3 H, m), 7.45 (1 H, tm, $J=7.8,1.2 \mathrm{~Hz}), 7.36-7.27$ (4 H, m), 7.21 (1 H, m), 7.16-7.08 (2 H, m), 4.06 (1 H, s), 1.17 (9 H, s); ${ }^{13} \mathrm{C}$ NMR $\delta 137.4,133.4,132.4,132.2,132.0,131.5,131.0,130.3,129.7$, 
$128.4,128.1,128.0,127.9,127.6,127.5,127.4,127.3,127.0,126.7,126.5,126.3,126.1$, 125.7, 123.1, 95.8, 93.0, 88.6, 82.9, 51.2, 36.0, 27.9; MS m/z $498\left(\mathrm{M}^{+}\right), 441$.

7-(1,1-Dimethylethyl)-13-phenyl-8H-indeno[2,1-b]phenanthrene (167a). The following procedure is representative for the preparation of phenanthrenes 167. To a solution of 0.182 $\mathrm{g}$ of 166a $(0.46 \mathrm{mmol})$ in $10 \mathrm{~mL}$ of anhydrous toluene under a nitrogen atmosphere were added $0.50 \mathrm{~mL}$ of a $1.0 \mathrm{M}$ solution of potassium $t$-butoxide $(0.50 \mathrm{mmol})$ in 2-methyl-2-propanol and $0.35 \mathrm{~mL}$ of 2-methyl-2-propanol $(3.65 \mathrm{mmol})$. The reaction mixture was then heated under reflux for $3 \mathrm{~h}$. After the reaction mixture was allowed to cool to $\mathrm{rt}, 10 \mathrm{~mL}$ of water and $20 \mathrm{~mL}$ of methylene chloride were introduced, and then the organic layer was separated, dried over sodium sulfate, and concentrated. Purification by flash column chromatography (silica gel $/ 5 \%$ diethyl ether in hexanes) afforded $0.163 \mathrm{~g}$ of $\mathbf{1 6 7 a}$ (0.41 mmol, 89\%) as a yellow solid: mp $156-157{ }^{\circ} \mathrm{C}$; IR 1440, $1364 \mathrm{~cm}^{-1} ;{ }^{1} \mathrm{H}$ NMR $\delta(600$ $\left.\mathrm{MHz} \mathrm{CDCl}_{3}\right) 8.41(1 \mathrm{H}, \mathrm{d}, J=9.6 \mathrm{~Hz}), 7.78(1 \mathrm{H}, \mathrm{d}, J=7.8 \mathrm{~Hz}), 7.66(1 \mathrm{H}, \mathrm{d}, J=8.4 \mathrm{~Hz})$, 7.61-7.58 (4 H, m), 7.50 (1 H, d, J=7.2 Hz), 7.46-7.42 (2 H, m), 7.37 (1 H, t, $J=7.5 \mathrm{~Hz})$, $7.18(1 \mathrm{H}, \mathrm{t}, J=7.5 \mathrm{~Hz}), 6.99(1 \mathrm{H}, \mathrm{tm}, J=8.1,1.2 \mathrm{~Hz}), 6.92(1 \mathrm{H}, \mathrm{t}, J=7.8 \mathrm{~Hz}), 5.99(1 \mathrm{H}$, $\mathrm{d}, J=7.8 \mathrm{~Hz}), 4.45(2 \mathrm{H}, \mathrm{s}), 1.90(9 \mathrm{H}, \mathrm{s}) ;{ }^{13} \mathrm{C} \mathrm{NMR} \delta\left(150 \mathrm{MHz}, \mathrm{CDCl}_{3}\right) 144.2,143.3141 .8$, $141.1,139.9,138.8,134.0,132.5,131.5,131.3,130.4,130.2,129.9,129.1,127.7,127.2$, $126.5,126.1,126.0,125.4,123.9,123.80,123.78,123.5,40.3,38.5,34.1 ; m / z 398\left(\mathrm{M}^{+}\right), 383$, 341. HRMS calcd for $\mathrm{C}_{31} \mathrm{H}_{26}$ 398.2035, found 398.2043. Recrystallization of 167a from $\mathrm{CH}_{2} \mathrm{Cl}_{2} /$ hexanes produced a crystal suitable for X-ray structure analysis.

9-(1,1-Dimethylethyl)-15-phenyl-10H-benz[c]indeno[1,2-h]phenanthrene (167b). The same procedure was repeated as described for 167a except that a solution of $0.280 \mathrm{~g}$ of $\mathbf{1 6 6 \mathbf { b }}$ $(0.63 \mathrm{mmol})$ in $10 \mathrm{~mL}$ of anhydrous toluene was treated with $0.077 \mathrm{~g}$ of potassium $t$-butoxide $(0.69 \mathrm{mmol})$ and $0.48 \mathrm{~mL}$ of 2-methyl-2-propanol $(5.00 \mathrm{mmol})$ and then the resulting mixture was heated under reflux for $3 \mathrm{~h}$ to afford $0.232 \mathrm{~g}$ of $\mathbf{1 6 7 b}(0.52 \mathrm{mmol}, 83 \%)$ as a yellow solid: mp $169-171{ }^{\circ} \mathrm{C}$; IR 1366, $831 \mathrm{~cm}^{-1} ;{ }^{1} \mathrm{H} \mathrm{NMR} \delta\left(600 \mathrm{MHz}, \mathrm{CDCl}_{3},-20\right.$ $\left.{ }^{\circ} \mathrm{C}\right) 8.34(1 \mathrm{H}, \mathrm{d}, J=8.4 \mathrm{~Hz}), 8.01(1 \mathrm{H}, \mathrm{d}, J=7.8 \mathrm{~Hz}), 7.84(1 \mathrm{H}, \mathrm{d}, J=7.8 \mathrm{~Hz}), 7.76(1 \mathrm{H}, \mathrm{t}$, $J=8.4 \mathrm{~Hz}), 7.75(1 \mathrm{H}, \mathrm{t}, J=8.4 \mathrm{~Hz}), 7.62(1 \mathrm{H}, \mathrm{d}, J=7.8 \mathrm{~Hz}), 7.55(1 \mathrm{H}, \mathrm{d}, J=8.4 \mathrm{~Hz})$, $7.52(1 \mathrm{H}, \mathrm{d}, J=7.8 \mathrm{~Hz}), 7.33(1 \mathrm{H}, \mathrm{t}, J=7.5 \mathrm{~Hz}), 7.18(1 \mathrm{H}, \mathrm{t}, J=7.2 \mathrm{~Hz}), 7.16(1 \mathrm{H}, \mathrm{t}, J=$ 
$7.2 \mathrm{~Hz}), 7.02(1 \mathrm{H}, \mathrm{t}, J=7.5 \mathrm{~Hz}), 6.97(1 \mathrm{H}, \mathrm{t}, J=7.2 \mathrm{~Hz}), 6.88(1 \mathrm{H}, \mathrm{t}, J=7.2 \mathrm{~Hz}), 6.72(1$ H, t, $J=7.8 \mathrm{~Hz}), 6.27(1 \mathrm{H}, \mathrm{d}, J=8.4 \mathrm{~Hz}), 6.07(1 \mathrm{H}, \mathrm{d}, J=7.8 \mathrm{~Hz}), 4.545(1 \mathrm{H}, \mathrm{d}, J=21.6$ $\mathrm{Hz}), 4.331(1 \mathrm{H}, \mathrm{d}, J=21.0 \mathrm{~Hz}), 1.84(9 \mathrm{H}, \mathrm{s}) ;{ }^{13} \mathrm{C} \mathrm{NMR} \delta\left(150 \mathrm{MHz}, \mathrm{CDCl}_{3}, 25{ }^{\circ} \mathrm{C}\right) 144.4$, $140.9,140.7,140.6$, 139.0, 138.6, 134.6, 133.2, 131.5, 130.9, 130.6, 130.4, 130.1, 128.0, $127.7,127.1,126.8,126.5,126.0,125.9,125.5,124.8,124.4,124.3,124.2,123.9,122.3$, 40.0, 38.2, 33.5; MS m/z $448\left(\mathrm{M}^{+}\right)$, 433, 391. HRMS calcd for $\mathrm{C}_{35} \mathrm{H}_{28}$ 448.2191, found 448.2193.

The chemical shift of the AB quartet was calculated according to the equation: $\delta_{\alpha}=\left[\left(v_{1}+\right.\right.$ $\left.\left.v_{4}\right)+\left\{\left(v_{1}-v_{4}\right)\left(v_{2}-v_{3}\right)\right\}^{1 / 2}\right] / 2$

In addition to $\mathbf{1 6 7 b}$, the formation of a minor amount (ca. $2 \%$ ) of the intramolecular $[2+$ 2] cycloaddition adduct 168b was also detected with characteristic ${ }^{1} \mathrm{H}$ NMR signals (600 $\left.\mathrm{MHz}, \mathrm{CDCl}_{3}\right)$ at $\delta 8.84(1 \mathrm{H}, \mathrm{s}), 8.40(1 \mathrm{H}, \mathrm{d}, J=9.0 \mathrm{~Hz}), 8.12(2 \mathrm{H}, \mathrm{d}, J=8.4 \mathrm{~Hz}), 7.84(1$ $\mathrm{H}, \mathrm{d}, J=7.8 \mathrm{~Hz}), 6.49\left(1 \mathrm{H}, \mathrm{s}\right.$, vinylic), and $1.29(9 \mathrm{H}, \mathrm{s})$ and a ${ }^{13} \mathrm{C}$ NMR signal $(150 \mathrm{MHz}$, $\left.\mathrm{CDCl}_{3}\right)$ at $\delta 76.1$ attributable to the $\mathrm{sp}^{3}$ carbon on the four-membered ring as observed previously in similar systems. ${ }^{17}$

Indeno-Fused Dibenzo[c,g]phenanthrene 167c. The same procedure was repeated as described for 167a except that a solution of $0.120 \mathrm{~g}$ of 166c $(0.24 \mathrm{mmol})$ in $10 \mathrm{~mL}$ of anhydrous toluene was treated with $0.030 \mathrm{~g}$ of potassium $t$-butoxide $(0.26 \mathrm{mmol})$ and 0.18 $\mathrm{mL}$ of 2-methyl-2-propanol $(1.92 \mathrm{mmol})$ and then the resulting mixture was heated under reflux for $3 \mathrm{~h}$ to afford $0.094 \mathrm{~g}$ of $167 \mathrm{c}(0.19 \mathrm{mmol}, 78 \%)$ as a yellow solid: $\mathrm{mp}>250{ }^{\circ} \mathrm{C}$; IR 1366, $839 \mathrm{~cm}^{-1}$; ${ }^{1} \mathrm{H}$ NMR $\delta\left(600 \mathrm{MHz}, \mathrm{CDCl}_{3}\right) 8.42(1 \mathrm{H}, \mathrm{d}, J=8.4 \mathrm{~Hz}), 7.85(1 \mathrm{H}, \mathrm{d}, J=$ $8.4 \mathrm{~Hz}), 7.81(1 \mathrm{H}, \mathrm{d}, J=7.8 \mathrm{~Hz}), 7.76(1 \mathrm{H}, \mathrm{d}, J=8.4 \mathrm{~Hz}), 7.618(1 \mathrm{H}, \mathrm{d}, J=6.0 \mathrm{~Hz}), 7.605$ $(1 \mathrm{H}, \mathrm{d}, J=9 \mathrm{~Hz}), 7.52(1 \mathrm{H}, \mathrm{d}, J=8.4 \mathrm{~Hz}), 7.45(1 \mathrm{H}, \mathrm{d}, J=7.8 \mathrm{~Hz}), 7.40(1 \mathrm{H}, \mathrm{d}, J=8.4$ Hz), $7.32(1 \mathrm{H}, \mathrm{td}, J=7.5,1.2 \mathrm{~Hz}), 7.12(1 \mathrm{H}, \mathrm{ddd}, J=7.8,6.6,1.2 \mathrm{~Hz}), 7.08(1 \mathrm{H}, \mathrm{td}, J=$ 7.8, $0.8 \mathrm{~Hz}), 6.73(2 \mathrm{H}, \mathrm{t}, J=7.5 \mathrm{~Hz}), 6.558(1 \mathrm{H}, \mathrm{t}, J=8.4 \mathrm{~Hz}), 6.546(1 \mathrm{H}, \mathrm{t}, J=7.8 \mathrm{~Hz})$, $6.42(1 \mathrm{H}, \mathrm{d}, J=7.8 \mathrm{~Hz}), 6.04(1 \mathrm{H}, \mathrm{d}, J=8.4 \mathrm{~Hz}), 5.76(1 \mathrm{H}, \mathrm{d}, J=7.8 \mathrm{~Hz}), 4.58(1 \mathrm{H}, \mathrm{d}, J$ $=21.0 \mathrm{~Hz}), 4.28(1 \mathrm{H}, \mathrm{d}, J=21.0 \mathrm{~Hz}), 1.97(9 \mathrm{H}, \mathrm{s}) ;{ }^{13} \mathrm{C} \mathrm{NMR} \delta\left(150 \mathrm{MHz}, \mathrm{CDCl}_{3}\right) 144.3$, $141.0,140.8,139.3,139.2,138.3,134.5,132.7,132.0,131.8,131.5,131.4,131.3,129.5$, $129.22,129.18,127.7,127.0,126.8,126.6,126.5,126.4,126.0,125.74,125.70,125.67$, 
$125.59,125.45,125.3,125.04,125.03,123.82,123.80,122.1,40.1,38.3,33.8 . \mathrm{MS} m / z 498$ $\left(\mathrm{M}^{+}\right)$, 441, 363. HRMS calcd for $\mathrm{C}_{39} \mathrm{H}_{30}$ 498.2348, found 498.2351. Recrystallization of 167c from $\mathrm{CH}_{2} \mathrm{Cl}_{2} /$ hexanes produced a crystal suitable for X-ray structure analysis.

In addition to $167 \mathrm{c}$, the formation of a minor amount (ca. $12 \%$ ) of the intramolecular [2 +2] cycloaddition adduct 168c was also detected with characteristic ${ }^{1} \mathrm{H}$ NMR signals (600 $\left.\mathrm{MHz}, \mathrm{CDCl}_{3}\right)$ at $\delta 9.28(1 \mathrm{H}, \mathrm{s}), 8.88(1 \mathrm{H}, \mathrm{d}, J=8.4 \mathrm{~Hz}), 8.12(2 \mathrm{H}, \mathrm{d}, J=8.4 \mathrm{~Hz}), 7.99(1$ $\mathrm{H}, \mathrm{d}, J=7.8 \mathrm{~Hz}), 6.51\left(1 \mathrm{H}, \mathrm{s}\right.$, vinylic), and $1.27(9 \mathrm{H}, \mathrm{s})$ and a ${ }^{13} \mathrm{C}$ NMR signal $(150 \mathrm{MHz}$, $\left.\mathrm{CDCl}_{3}\right)$ at $\delta 76.3$ attributable to the $\mathrm{sp}^{3}$ carbon on the four-membered ring as observed previously in similar systems. ${ }^{17}$

1,5-Dibromo-2,4-bis(phenylethynyl)benzene (188a). The following procedure is representative for the preparation of the 1,5-dibromo-2,4-bis(arylethynyl)benzenes. To a flask containing $0.051 \mathrm{~g}$ of dichlorobis(triphenylphosphine)palladium $(0.072 \mathrm{mmol})$ and $0.092 \mathrm{~g}$ of $\mathrm{CuI}(0.048 \mathrm{mmol})$ was added via cannula a solution of $0.296 \mathrm{~g}$ of 1,5-dibromo-2,4-diiodo-

-benzene $(\mathbf{1 8 6}, 0.61 \mathrm{mmol})$ in $20 \mathrm{~mL}$ of triethylamine followed by a solution of $0.124 \mathrm{~g}$ of phenylacetylene $(\mathbf{1 8 7 a}, 1.22 \mathrm{mmol})$ in $10 \mathrm{~mL}$ of triethylamine. The resulting mixture was heated at $70{ }^{\circ} \mathrm{C}$. After $1 \mathrm{~h}$, the mixture was allowed to cool to $\mathrm{rt}$ and concentrated. A saturated aqueous ammonium chloride solution $(20 \mathrm{~mL})$ was then added. After filtration, the filtrate was extracted with hexanes. The combined organic layers were washed with water, dried over $\mathrm{Na}_{2} \mathrm{SO}_{4}$, and concentrated. The residue was purified by flash column chromatography (silica gel/hexanes) to give $0.220 \mathrm{~g}(0.50 \mathrm{mmol}, 83 \%)$ of 188a as a yellow solid: IR 2247, $1457 \mathrm{~cm}^{-1}$; ${ }^{1} \mathrm{H}$ NMR $\delta 7.89(1 \mathrm{H}, \mathrm{s}), 7.73(1 \mathrm{H}, \mathrm{s}), 7.60-7.56(4 \mathrm{H}, \mathrm{m})$, 7.41-7.36 (6 H, m); ${ }^{13} \mathrm{C}$ NMR $\delta 136.5,135.7,131.7,129.0,128.4,125.3,124.8,122.4,95.3$, 86.6 .

1,5-Dibromo-2,4-bis[[4-(1,1,3,3-tetramethylbutyl)phenyl]ethynyl]benzene (188b). The same procedure was repeated as described for 188a except that $0.080 \mathrm{~g}$ of dichlorobis(triphenylphosphine)palladium $(0.11 \mathrm{mmol})$ and $0.014 \mathrm{~g}$ of $\mathrm{CuI}(0.076 \mathrm{mmol})$ were treated with a solution of $0.926 \mathrm{~g}$ of 1,5-dibromo-2,4-diiodobenzene $(\mathbf{1 8 6}, 1.87 \mathrm{mmol})$ in $40 \mathrm{~mL}$ of triethylamine and a solution of $0.812 \mathrm{~g}$ of 1-ethynyl-4-(1,1,3,3-teytamethylbutyl) 
-benzene $(\mathbf{1 8 7 b}, 3.79 \mathrm{mmol})$ in $20 \mathrm{~mL}$ of triethylamine to afford $0.862 \mathrm{~g}$ of $\mathbf{1 8 8 b}(1.31 \mathrm{mmol}$, $69 \%$ ) as a yellow solid: IR 2214, 1508,1454,831 $\mathrm{cm}^{-1} ;{ }^{1} \mathrm{H}$ NMR $\delta 7.88(1 \mathrm{H}, \mathrm{s}), 7.70(1 \mathrm{H}, \mathrm{s})$, 7.49 (4 H, d, $J=8.7, \mathrm{~Hz}), 7.38$ (4 H, d, $J=8.7, \mathrm{~Hz}), 1.76(4 \mathrm{H}, \mathrm{s}), 1.37(12 \mathrm{H}, \mathrm{s}), 0.73(18 \mathrm{H}$, s); ${ }^{13} \mathrm{C}$ NMR $\delta 151.5,136.3,135.6,131.2,126.3,124.95,124.91,119.1,95.7,86.1,56.7$, $38.8,32.3,31.8,31.4$.

\section{1,5-Bis(trimethylsilylethynyl)-2,4-bis(phenylethynyl)benzene (189a). The following} procedure is representative for the preparation of the tetraacetylenes. A $2.5 \mathrm{M}$ solution of $n$-butyllithium $(3.7 \mathrm{~mL}, 9.36 \mathrm{mmol})$ in hexanes was added dropwise to a solution of $1.70 \mathrm{~g}$ of 188a (3.90 mmol) in diethyl ether $(20 \mathrm{~mL})$ at $-78{ }^{\circ} \mathrm{C}$. After $2 \mathrm{~h}$ of stirring at $-78{ }^{\circ} \mathrm{C}, 2.38 \mathrm{~g}$ of $\mathrm{I}_{2}(9.36 \mathrm{mmol})$ in $40 \mathrm{~mL}$ of diethyl ether was added via cannula at $-78{ }^{\circ} \mathrm{C}$ and the mixture was then allowed to warm to rt. After $12 \mathrm{~h}, 40 \mathrm{~mL}$ of a $5 \%$ aqueous solution of sodium thiosulfate was added, and the organic layer was separated, washed with water, dried with sodium sulfate, and concentrated to furnish crude 1,5-diiodo-2,4-bis(phenylethynyl)benzene as a yellow solid. It was used for the next step without further purification. To a flask containing $0.164 \mathrm{~g}$ of dichlorobis(triphenylphosphine)palladium $(0.234 \mathrm{mmol})$ and $0.045 \mathrm{~g}$ of $\mathrm{CuI}(0.234 \mathrm{mmol})$ were added via cannula a solution of the crude product of 1,5-diiodo-2,4-bis(phenylethynyl)benzene in $30 \mathrm{~mL}$ of triethylamine followed by a solution of $0.919 \mathrm{~g}$ of (trimethylsilyl)acetylene in $15 \mathrm{~mL}$ of triethylamine. The resulting mixture was heated at $45{ }^{\circ} \mathrm{C}$. After $3 \mathrm{~h}$, the mixture was allowed to cool to $\mathrm{rt}$ and concentrated. A saturated aqueous ammonium chloride solution $(20 \mathrm{~mL})$ was then added. After filtration, the filtrate was extracted with diethyl ether. The combined organic layers were washed with water, dried over sodium sulfate, and concentrated. The residue was purified by flash column chromatography (silica gel/hexanes) to give $1.05 \mathrm{~g}(2.24 \mathrm{mmol}, 57 \%)$ of 189a as a yellow solid: IR 2218, 2254, 1496, $1250 \mathrm{~cm}^{-1} ;{ }^{1} \mathrm{H}$ NMR $\delta 7.68(1 \mathrm{H}, \mathrm{s}), 7.66(1 \mathrm{H}, \mathrm{s}), 7.57-7.53(4$ $\mathrm{H}, \mathrm{m}), 7.37-7.35(6 \mathrm{H}, \mathrm{m}) ;{ }^{13} \mathrm{C}$ NMR $\delta 136.0,134.7,131.8,128.7,128.4,125.7,124.9$, $122.9,102.3,100.8,95.4,87.3,-0.1$.

\section{1,5-Bis(trimethylsilylethynyl)-2,4-bis[[4-(1,1,3,3-tetramethylbutyl)phenyl]ethynyl]-}

-benzene (189b). The same procedure was repeated as described for 189a except that 0.689 $\mathrm{g}$ of $\mathbf{1 8 8 b}(1.04 \mathrm{mmol})$ was treated with a $2.5 \mathrm{M}$ solution of $n$-butyllithium $(2.0 \mathrm{~mL}, 3.13$ 
$\mathrm{mmol})$ in hexanes and a solution of $0.795 \mathrm{~g}$ of $\mathrm{I}_{2}(3.13 \mathrm{mmol})$ in $30 \mathrm{~mL}$ of diethyl ether followed by $0.044 \mathrm{~g}$ of dichlorobis(triphenylphosphine)palladium $(0.063 \mathrm{mmol})$ and $0.012 \mathrm{~g}$ of $\mathrm{CuI}(0.062 \mathrm{mmol})$ and then a solution of $0.246 \mathrm{~g}$ of (trimethylsilyl)acetylene in $15 \mathrm{~mL}$ of triethylamine to afford $0.362 \mathrm{~g}$ of $\mathbf{1 8 9 b}(0.52 \mathrm{mmol}, 50 \%)$ as a white solid: IR 2151,1511 , $1250 \mathrm{~cm}^{-1}$; ${ }^{1} \mathrm{H}$ NMR $\delta 7.65(2 \mathrm{H}, \mathrm{s}), 7.46(4 \mathrm{H}, \mathrm{d}, J=8.4, \mathrm{~Hz}), 7.36(4 \mathrm{H}, \mathrm{d}, J=8.4, \mathrm{~Hz})$, $1.75(4 \mathrm{H}, \mathrm{s}), 1.37(12 \mathrm{H}, \mathrm{s}), 0.71(18 \mathrm{H}, \mathrm{s}), 0.26(18 \mathrm{H}, \mathrm{s}) ;{ }^{13} \mathrm{C} \mathrm{NMR} \delta 151.2,136.0,134.5$, $131.3,126.2$, 126.0, 124.6, 119.6, 102.4, 100.6, 95.8, 86.8, 56.8, 38.8, 32.4, 31.8, 31.4, -0.1 . 1,5-Diethynyl-2,4-bis(phenylethynyl)benzene (171a). The following procedure is representative for the preparation of the 1,5-diethynyl-2,4-bis(arylethynyl)benzenes. To $0.762 \mathrm{~g}$ of 189a $(1.63 \mathrm{mmol})$ in $40 \mathrm{~mL}$ of diethyl ether were added $40 \mathrm{~mL}$ of methanol and $25 \mathrm{~mL}$ of a $10 \%$ aqueous solution of sodium hydroxide. After $30 \mathrm{~min}$ stirring at $\mathrm{rt}$, the organic solvents were removed in vacuo. Water $(30 \mathrm{~mL})$ and diethyl ether $(50 \mathrm{~mL})$ were then added. The organic layer was separated, washed with $2 \mathrm{M}$ solution of aqueous hydrochloric acid and water, dried over sodium sulfate 4 , and concentrated. The residue was purified by flash column chromatography (silica gel/hexanes) to give $0.515 \mathrm{~g}(1.58 \mathrm{mmol}, 93 \%)$ of 171a as a yellow solid: IR 3289, 2212, 1598, $1496 \mathrm{~cm}^{-1} ;{ }^{1} \mathrm{H}$ NMR $\delta 7.72(1 \mathrm{H}, \mathrm{s}), 7.69(1 \mathrm{H}, \mathrm{s})$, 7.59-7.56 (4 H, m), 7.39-7.36 (6 H, m); ${ }^{13} \mathrm{C}$ NMR $\delta 136.4,134.8,131.8,128.9,128.4,126.5$, $123.9,122.6,95.7,86.8,83.0,81.0$.

1,5-Diethynyl-2,4-bis[[4-(1,1,3,3-tetramethylbutyl)phenyl]ethynyl]benzene (171b). The same procedure was repeated as described for 171a except that $0.376 \mathrm{~g}$ of $\mathbf{1 8 9 b}(0.54 \mathrm{mmol})$ in $20 \mathrm{~mL}$ of diethyl ether was treated with $15 \mathrm{~mL}$ of methanol and $15 \mathrm{~mL}$ of a $10 \%$ aqueous solution of sodium hydroxide to afford $0.289 \mathrm{~g}(053 \mathrm{mmol}, 97 \%)$ of $\mathbf{1 7 1 b}$ as a yellow solid: IR 3302, 2211, 1511, $1478 \mathrm{~cm}^{-1}$; ${ }^{1} \mathrm{H}$ NMR $\delta 7.69(1 \mathrm{H}, \mathrm{s}), 7.67(1 \mathrm{H}, \mathrm{s}), 7.48(4 \mathrm{H}, \mathrm{d}, J=8.4$, $\mathrm{Hz}), 7.38(4 \mathrm{H}, J=8.4, \mathrm{~Hz}), 3.44(2 \mathrm{H}, \mathrm{s}), 1.76(4 \mathrm{H}, \mathrm{s}), 1.40(12 \mathrm{H}, \mathrm{s}), 0.73(18 \mathrm{H}, \mathrm{s}) ;{ }^{13} \mathrm{C}$ NMR $\delta 151.5,136.4,134.6,131.4,126.7,126.3,123.6,119.4,96.1,86.3,82.8,81.2,56.8$, $38.8,32.4,31.8,31.4$.

Propargylic Alcohol 172a. The same procedure was repeated as described for 165a except that $0.126 \mathrm{~g}$ of 2,2-dimethylpropiophenone $(147,0.78 \mathrm{mmol})$ was treated with the lithium acetylide, prepared from $0.127 \mathrm{~g}$ of tetraacetylene 171a $(0.39 \mathrm{mmol})$ and $0.49 \mathrm{~mL}$ of a $2.0 \mathrm{M}$ 
solution of lithium diisopropylamide $(0.98 \mathrm{mmol})$ in THF/n-heptane, to afford $0.220 \mathrm{~g}$ of 172a $(0.34 \mathrm{mmol}, 87 \%)$ as a white solid: IR 3371, 2212, 1598, $1498 \mathrm{~cm}^{-1} ;{ }^{1} \mathrm{H}$ NMR $\delta 7.75$ (1H, s), 7.74-7.71 (4 H, m), $7.63(1 \mathrm{H}, \mathrm{s}), 7.47-7.43$ (4 H, m), 7.36-7.31 (6 H, m), 7.28-7.24 (6 H, m), 2.42 (2 H, s), 1.09 (18 H,s); ${ }^{13} \mathrm{C}$ NMR $\delta 141.7,135.67,135.61,131.8,128.7,128.3$, $127.7,127.4,127.1,125.5,124.5,122.6,98.3,95.1,87.3,83.6,79.6,39.8,25.6$.

Propargylic Alcohol 172b. The same procedure was repeated as described for 165a except that $0.123 \mathrm{~g}$ of 2,2-dimethylpropiophenone $(147,0.76 \mathrm{mmol})$ was treated with the lithium acetylide, prepared from $0.209 \mathrm{~g}$ of tetraacetylene $171 \mathrm{~b}(0.38 \mathrm{mmol})$ and $0.48 \mathrm{~mL}$ of a $2.0 \mathrm{M}$ solution of lithium diisopropylamide $(0.96 \mathrm{mmol})$ in $\mathrm{THF} / n$-heptane, to afford $0.156 \mathrm{~g}$ of 172b (0.18 mmol, 47\%) as a white solid: IR 3540, 2210, 1483, $833 \mathrm{~cm}^{-1} ;{ }^{1} \mathrm{H}$ NMR $\delta 7.74(2$ H, d, $J=6.2 \mathrm{~Hz}), 7.73(2 \mathrm{H}, \mathrm{d}, J=6.2 \mathrm{~Hz}), 7.72(1 \mathrm{H}, \mathrm{s}), 7.62(1 \mathrm{H}, \mathrm{s}), 7.39(4 \mathrm{H}, \mathrm{d}, J=8.7$ Hz), 7.33 (4 H, d, J=8.7 Hz), 7.26-7.23 (6 H, m), 2.45 (2 H, s), 1.76 (4 H, s), 1.38 (12 H, s), 1.09 (18 H, s), $0.73(18 \mathrm{H}, \mathrm{s}) ;{ }^{13} \mathrm{C} \mathrm{NMR} \delta 151.2,141.8,135.6,135.5,131.3,127.7,127.3$, $127.1,126.2,125.8,124.2,119.3,98.0,95.4,86.8,83.7,79.6,56.8,39.8,38.7,32.4,31.8$, 31.4, 25.6 .

Propargylic Alcohol 180a. The same procedure was repeated as described for 165a except that $0.134 \mathrm{~g}$ of 2,2-dimethyl-1-(2-naphthalenyl)-1-propanone (160a, $0.63 \mathrm{mmol}$ ) was treated with the lithium acetylide, prepared from $0.103 \mathrm{~g}$ of tetraacetylene 171a $(0.31 \mathrm{mmol})$ and $0.40 \mathrm{~mL}$ of a $2.0 \mathrm{M}$ solution of lithium diisopropylamide $(0.80 \mathrm{mmol}) \mathrm{in} \mathrm{THF} / n$-heptane, to afford $0.176 \mathrm{~g}$ of 180a $(0.24 \mathrm{mmol}, 74 \%)$ as a white solid: IR $3354,1599,1498 \mathrm{~cm}^{-1} ;{ }^{1} \mathrm{H}$ NMR $\delta 8.18(2 \mathrm{H}, \mathrm{s}), 7.88(2 \mathrm{H}, \mathrm{dd}, J=8.6,1.7 \mathrm{~Hz}), 7.81-7.78(4 \mathrm{H}, \mathrm{m}), 7.69(2 \mathrm{H}, \mathrm{d}, J=$ 8.6, Hz), 7.68 (1 H, s), 7.50-7.41 (4 H, m), 7.37-7.34 (5 H, m), $7.29(1 \mathrm{H}, \mathrm{s}), 7.17$ (4 H, t, J $=7.6 \mathrm{~Hz}), 2.60(2 \mathrm{H}, \mathrm{s}), 1.16(18 \mathrm{H}, \mathrm{s}) ;{ }^{13} \mathrm{C} \mathrm{NMR} \delta 139.4,135.7,135.6,132.7,132.4,131.7$, $128.7,128.4,128.2,127.4,126.5,126.4,126.1,126.0,125.9,125.7,124.5,122.5,98.2,95.2$, $87.3,83.8,79.7,40.1,25.7$.

Propargylic Alcohol 180b. The same procedure was repeated as described for 165a except that $0.051 \mathrm{~g}$ of 2,2-dimethyl-1-(2-naphthalenyl)-1-propanone (160a, $0.24 \mathrm{mmol}$ ) was treated with the lithium acetylide, prepared from $0.066 \mathrm{~g}$ of tetraacetylene $171 \mathrm{~b}(0.12 \mathrm{mmol})$ and $0.15 \mathrm{~mL}$ of a $2.0 \mathrm{M}$ solution of lithium diisopropylamide $(0.30 \mathrm{mmol}) \mathrm{in} \mathrm{THF} / n$-heptane, to 
afford $0.054 \mathrm{~g}$ of $\mathbf{1 8 0 b}(0.06 \mathrm{mmol}, 46 \%)$ as a white solid: IR 3352, 2210, 1511, $1483 \mathrm{~cm}^{-1}$; ${ }^{1} \mathrm{H}$ NMR $\delta 8.21(2 \mathrm{H}, \mathrm{s}), 7.91(2 \mathrm{H}, \mathrm{dd}, J=8.7,1.7 \mathrm{~Hz}), 7.84-7.79(4 \mathrm{H}, \mathrm{m}), 7.75(1 \mathrm{H}, \mathrm{s})$, $7.72(2 \mathrm{H}, \mathrm{d}, J=8.7 \mathrm{~Hz}), 7.67(1 \mathrm{H}, \mathrm{s}), 7.50-7.42(4 \mathrm{H}, \mathrm{m}), 7.22(4 \mathrm{H}, \mathrm{d}, J=8.7 \mathrm{~Hz}), 7.13$ (4 H, d, $J=8.7 \mathrm{~Hz}), 2.62(2 \mathrm{H}, \mathrm{s}), 1.71(4 \mathrm{H}, \mathrm{s}), 1.32(12 \mathrm{H}, \mathrm{s}), 1.16(18 \mathrm{H}, \mathrm{s}), 0.71(18 \mathrm{H}, \mathrm{s})$; ${ }^{13} \mathrm{C}$ NMR $\delta 151.2,139.6,135.7,135.4,132.7,132.5,131.2,128.5,127.4,126.6,126.4$, $126.3,126.1,126.0,125.9,124.2,119.2,98.0,95.6,86.8,83.9,79.7,56.7,40.1,38.7,32.3$, $31.8,31.4,31.3,25.7$.

Propargylic Alcohol 183. The same procedure was repeated as described for 179a except that $0.445 \mathrm{~g}$ of 2,2-dimethyl-1-(3-phenanthryl)-1-propanone (160b, $1.70 \mathrm{mmol})$ was treated with the lithium acetylide, prepared from $0 . .277 \mathrm{~g}$ of tetraacetylene 171a $(0.85 \mathrm{mmol})$ and $1.1 \mathrm{~mL}$ of a $2.0 \mathrm{M}$ solution of lithium diisopropylamide $(2.20 \mathrm{mmol})$ in $\mathrm{THF} / n$-heptane, to afford $0.526 \mathrm{~g}$ of $183(0.62 \mathrm{mmol}, 73 \%)$ as a white solid: IR $3546,2210,1498 \mathrm{~cm}^{-1} ;{ }^{1} \mathrm{H}$ NMR $\delta 9.06(2 \mathrm{H}, \mathrm{s}), 8.77-8.74(2 \mathrm{H}, \mathrm{m}), 8.01(2 \mathrm{H}, \mathrm{dd}, J=8.4,1.5 \mathrm{~Hz}), 7.89-7.86(2 \mathrm{H}, \mathrm{m})$, $7.81(1 \mathrm{H}, \mathrm{s}), 7.75-7.68$ (7 H, m), 7.60-7.55 (4 H, m), 7.34 (4 H, d, J= 7.4, Hz), 7.24 -7.21 $(2 \mathrm{H}, \mathrm{m}), 7.12(4 \mathrm{H}, \mathrm{t}, J=7.7 \mathrm{~Hz}), 2.76(2 \mathrm{H}, \mathrm{s}), 1.21(18 \mathrm{H}, \mathrm{s}) ;{ }^{13} \mathrm{C}$ NMR $\delta 140.1,135.76$, $135.71,132.1,131.7,131.2,130.5,129.2,128.6,128.5,128.1,127.2,127.0,126.6,126.54$, 126.50, 126.4, 125.8, 124.5, 122.7, 122.4, 121.4, 98.4, 95.4, 87.3, 83.9, 80.0, 40.0, 25.7.

Tetraacetylenic Hydrocarbon 173a. The same procedure was repeated as described for 166a except that $0.190 \mathrm{~g}$ of 172a $(0.29 \mathrm{mmol})$ was treated with $0.102 \mathrm{~g}$ of triethylsilane $(0.87 \mathrm{mmol})$ and $0.18 \mathrm{~mL}$ of trifluoroacetic acid $(0.266 \mathrm{~g}, 2.33 \mathrm{mmol})$ in $15 \mathrm{~mL}$ methylene chloride to afford $0.155 \mathrm{~g}$ of $\mathbf{1 7 3 a}(0.25 \mathrm{mmol}, 85 \%)$ as a yellow solid: IR 2221, 1599, 1497 $\mathrm{cm}^{-1} ;{ }^{1} \mathrm{H}$ NMR $\delta 7.73(1 \mathrm{H}, \mathrm{s}), 7.57(1 \mathrm{H}, \mathrm{s}), 7.45-7.40(8 \mathrm{H}, \mathrm{m}), 7.35-7.31(6 \mathrm{H}, \mathrm{m})$, 7.25-7.21 (6 H, m), $3.72(2 \mathrm{H}, \mathrm{s}), 1.07$ (18 H, s); ${ }^{13} \mathrm{C}$ NMR $\delta 138.9,135.55,135.50,131.7$, $129.7,128.5,128.2,127.6,126.7,125.7,124.7,122.9,97.6,94.3,87.7,81.7,50.7,35.5$, 27.8 .

Tetraacetylenic Hydrocarbon 173b. The same procedure was repeated as described for 166a except that $0.111 \mathrm{~g}$ of $\mathbf{1 7 2 b}(0.13 \mathrm{mmol})$ was treated with $0.044 \mathrm{~g}$ of triethylsilane $(0.38 \mathrm{mmol})$ and $0.08 \mathrm{~mL}$ of trifluoroacetic acid $(1.01 \mathrm{mmol})$ in $10 \mathrm{~mL}$ of methylene chloride to afford $0.092 \mathrm{~g}$ of $\mathbf{1 7 3 b}(0.11 \mathrm{mmol}, 85 \%)$ as a yellow solid: IR $2214,1365,833$ 
$\mathrm{cm}^{-1}$; ${ }^{1} \mathrm{H}$ NMR $\delta 7.69(1 \mathrm{H}, \mathrm{s}), 7.53(1 \mathrm{H}, \mathrm{s}), 7.42(2 \mathrm{H}, \mathrm{d}, J=7.7 \mathrm{~Hz}), 7.41(2 \mathrm{H}, \mathrm{d}, J=7.7$ Hz), 7.35 (4 H, d, $J=8.7 \mathrm{~Hz}), 7.31(4 \mathrm{H}, \mathrm{d}, J=8.7 \mathrm{~Hz}), 7.23-7.20$ (6 H, m), $3.70(2 \mathrm{H}, \mathrm{s})$, $1.76(4 \mathrm{H}, \mathrm{s}), 1.37(12 \mathrm{H}, \mathrm{s}), 1.04(18 \mathrm{H}, \mathrm{s}), 0.72(18 \mathrm{H}, \mathrm{s}) ;{ }^{13} \mathrm{C} \mathrm{NMR} \delta 150.9,139.0,135.5$, $135.4,131.2$, 129.8, 127.6, 126.6, 126.1, 125.4, 124.9, 119.7, 97.3, 94.6, 87.2, 81.8, 56.8, $50.7,38.7,35.5,32.4,31.8,31.4,27.8$.

Tetraacetylenic Hydrocarbon 181a. The same procedure was repeated as described for 166a except that $0.151 \mathrm{~g}$ of $180 \mathrm{a}(0.20 \mathrm{mmol})$ was treated with $0.070 \mathrm{~g}$ of triethylsilane $(0.60 \mathrm{mmol})$ and $0.13 \mathrm{~mL}$ of trifluoroacetic acid $(1.61 \mathrm{mmol})$ in $10 \mathrm{~mL}$ of methylene chloride to afford $0.129 \mathrm{~g}$ of 181a $(0.18 \mathrm{mmol}, 85 \%)$ as a yellow solid: IR $2253,1459 \mathrm{~cm}^{-1}$; ${ }^{1} \mathrm{H}$ NMR $\delta 7.85$ (2 H, s), 7.83-7.73 (6 H, m), 7.70 (2 H, s), 7.64-7.61 (3 H, m), 7.49-7.42 (4 $\mathrm{H}, \mathrm{m}), 7.34-7.25(7 \mathrm{H}, \mathrm{m}), 7.14(4 \mathrm{H}, \mathrm{t}, J=7.7 \mathrm{~Hz}), 3.92(2 \mathrm{H}, \mathrm{s}) .1 .14(18 \mathrm{H}, \mathrm{s}) ;{ }^{13} \mathrm{C} \mathrm{NMR} \delta$ $136.6,135.6,135.5,133.0,132.4,131.7,128.4,128.13,128.09,127.9,127.5,127.1,125.8$, $125.6,125.5,124.8,122.8,97.6,94.4,87.7,81.9,50.9,35.9,27.9$.

Tetraacetylenic Hydrocarbon 181b. The same procedure was repeated as described for 166a except that $0.053 \mathrm{~g}$ of $(0.05 \mathrm{mmol})$ was treated with $0.019 \mathrm{~g}$ of triethylsilane $(0.16$ $\mathrm{mmol})$ and $0.03 \mathrm{~mL}$ of trifluoroacetic acid $(0.43 \mathrm{mmol})$ in $5 \mathrm{~mL}$ of methylene chloride to afford $0.040 \mathrm{~g}$ of $\mathbf{1 8 1 b}(0.04 \mathrm{mmol}, 78 \%)$ as a yellow solid: IR 2212, 1510, $1476 \mathrm{~cm}^{-1} ;{ }^{1} \mathrm{H}$ NMR $\delta 7.85(1 \mathrm{H}, \mathrm{s}), 7.83-7.75(6 \mathrm{H}, \mathrm{m}), 7.71(2 \mathrm{H}, \mathrm{s}), 7.64(2 \mathrm{H}, \mathrm{dd}, J=8.4,1.2 \mathrm{~Hz}), 7.60$ (1 H, s), 7.47-7.44 (4 H, m), $7.15(4 \mathrm{H}, \mathrm{d}, J=8.2 \mathrm{~Hz}), 7.07$ (4 H, d, $J=8.2 \mathrm{~Hz}), 1.70$ (4 H, s), $1.32(12 \mathrm{H}, \mathrm{s}), 1.13(18 \mathrm{H}, \mathrm{s}), 0.71(18 \mathrm{H}, \mathrm{s}) ;{ }^{13} \mathrm{C}$ NMR $\delta 150.8,136.8,135.4,135.2$, $133.0,132.5,131.2,128.4,128.1,127.9,127.5,127.2$, 126.0, 125.8, 125.6, 125.3, 125.1, $119.5,97.2,94.8,87.2,82.1,56.7,50.9,38.6,35.8,32.3,31.7,31.4,27.9$.

Tetraacetylenic Hydrocarbon 184. The same procedure was repeated as described for 166a except that $0.513 \mathrm{~g}$ of $183(0.60 \mathrm{mmol})$ was treated with $0.210 \mathrm{~g}$ of triethylsilane $(1.81 \mathrm{mmol})$ and $0.39 \mathrm{~mL}$ of trifluoroacetic acid $(4.82 \mathrm{mmol})$ in $20 \mathrm{~mL}$ of methylene chloride to afford $0.414 \mathrm{~g}$ of $184(0.51 \mathrm{mmol}, 84 \%)$ as a yellow solid: IR 2224, $1498 \mathrm{~cm}^{-1} ;{ }^{1} \mathrm{H}$ NMR $\delta$ 8.70-8.67 (4 H, m), 7.89-7.85 (2 H, m), 7.76 (1 H, s), 7.72-7.70 (8 H, m), $7.64(1 \mathrm{H}, \mathrm{s})$, 7.58-7.54 (4 H, m), 7.30-7.27 (4 H, m), 7.19 (2 H, dd, $J=7.4,1.5 \mathrm{~Hz}), 7.08$ (4 H, td, $J=7.7$, $2.5 \mathrm{~Hz}), 4.01(2 \mathrm{H}, \mathrm{s}), 1.14(18 \mathrm{H}, \mathrm{s}) ;{ }^{13} \mathrm{C} \mathrm{NMR} \delta 137.4,135.6,132.1,131.6,130.9,130.2$, 
$129.7,128.5,128.4,128.0,127.9,126.6,126.53,126.46,125.6,124.9,123.5,122.73,122.65$, 97.6, 94.4, 87.7, 82.1, 51.3, 35.8, 27.9.

179a. The same procedure was repeated as described for 167a except that a solution of 0.076 $\mathrm{g}$ of 173a $(0.12 \mathrm{mmol})$ in $10 \mathrm{~mL}$ of anhydrous toluene was treated with $0.25 \mathrm{~mL}$ of a $1.0 \mathrm{M}$ solution of potassium $t$-butoxide $(0.25 \mathrm{mmol})$ in 2-methyl-2-propanol and $0.18 \mathrm{~mL}$ of 2-methyl-2-propanol $(1.93 \mathrm{mmol})$ and then the resulting mixture was heated under reflux for $3 \mathrm{~h}$ to afford $0.059 \mathrm{~g}$ of 179a $(0.09 \mathrm{mmol}, 78 \%)$ as a yellow solid: IR $1367,761 \mathrm{~cm}^{-1}$; ${ }^{1} \mathrm{H}$ NMR $\delta 8.54(2 \mathrm{H}, \mathrm{d}, J=8.4 \mathrm{~Hz}), 7.63(1 \mathrm{H}, \mathrm{s}), 7.41(2 \mathrm{H}, \mathrm{t}, J=7.2 \mathrm{~Hz}), 7.36-7.34(6 \mathrm{H}, \mathrm{m})$, $7.30(2 \mathrm{H}, \mathrm{d}, J=8.4 \mathrm{~Hz}), 7.20(2 \mathrm{H}, \mathrm{t}, J=7.2 \mathrm{~Hz}), 7.06(4 \mathrm{H}, \mathrm{d}, J=7.8 \mathrm{~Hz}), 6.65(1 \mathrm{H}, \mathrm{s})$, 4.52 (4 H, s), 1.89 (18 H, s); ${ }^{13} \mathrm{C}$ NMR $\delta 144.1,140.3,138.7,138.5,138.1,137.7,134.7$, $132.5,131.2$, 130.3 , 129.3, 127.7, 127.2, 127.0, 123.9, 123.1, 120.1, 119.4, 40.0, 38.8, 34.3; MS m/z $618\left(\mathrm{M}^{+}\right), 561$; HRMS calcd for $\mathrm{C}_{48} \mathrm{H}_{42}$ 618.3281, found 618.3295.

179b. The same procedure was repeated as described for 167a except that a solution of 0.024 $\mathrm{g}$ of 173b $(0.03 \mathrm{mmol})$ in $10 \mathrm{~mL}$ of anhydrous $p$-xylene was treated with $0.03 \mathrm{~mL}$ of a $1.0 \mathrm{M}$ solution of potassium $t$-butoxide $(0.03 \mathrm{mmol})$ in 2-methyl-2-propanol and $0.02 \mathrm{~mL}$ of 2-methyl-2-propanol $(0.16 \mathrm{mmol})$ and then the resulting mixture was heated under reflux for $5 \mathrm{~h}$ to afford $0.017 \mathrm{~g}$ of $\mathbf{1 7 9 b}(0.02 \mathrm{mmol}, 73 \%)$ as a yellow solid: IR 1466, 1365, $908 \mathrm{~cm}^{-1}$; ${ }^{1} \mathrm{H}$ NMR $\delta 8.53(2 \mathrm{H}, \mathrm{d}, J=9.0 \mathrm{~Hz}), 7.59(1 \mathrm{H}, \mathrm{s}), 7.55\left(2 \mathrm{H}, \mathrm{d}, J=7.8 \mathrm{~Hz}\right.$, at $\left.-25{ }^{\circ} \mathrm{C}\right), 7.40$ $(2 \mathrm{H}, \mathrm{dd}, J=8.4,1.2 \mathrm{~Hz}), 7.34(2 \mathrm{H}, \mathrm{td}, J=7.6,1.2 \mathrm{~Hz}), 7.21\left(2 \mathrm{H}, \mathrm{d}, J=7.8 \mathrm{~Hz}\right.$, at $\left.-25^{\circ} \mathrm{C}\right)$, $7.17(2 \mathrm{H}, \mathrm{t}, J=7.6 \mathrm{~Hz}), 7.08\left(2 \mathrm{H}, \mathrm{d}, J=7.8 \mathrm{~Hz}\right.$, at $\left.-25^{\circ} \mathrm{C}\right), 6.85(1 \mathrm{H}, \mathrm{s}), 6.70(2 \mathrm{H}, \mathrm{d}, J=$ $7.8 \mathrm{~Hz}$, at $\left.-25^{\circ} \mathrm{C}\right), 4.58(2 \mathrm{H}, \mathrm{d}, J=21.6 \mathrm{~Hz}), 4.44(2 \mathrm{H}, \mathrm{d}, J=21.6 \mathrm{~Hz}), 1.88(18 \mathrm{H}, \mathrm{s}), \mathrm{AB}$ pattern for $\mathrm{CH}_{2}, 1.72(6 \mathrm{H}, \mathrm{s}), 1.45(6 \mathrm{H}, \mathrm{s}), 0.77(18 \mathrm{H}, \mathrm{s})$; MS m/z $842\left(\mathrm{M}^{+}\right)$; HRMS calcd for $\mathrm{C}_{64} \mathrm{H}_{74} 842.5785$, found 842.5751 .

182a. The same procedure was repeated as described for 167a except that a solution of 0.209 $\mathrm{g}$ of 181a $(0.29 \mathrm{mmol})$ in $10 \mathrm{~mL}$ of anhydrous toluene was treated with $0.61 \mathrm{~mL}$ of a $1.0 \mathrm{M}$ solution of potassium $t$-butoxide $(0.61 \mathrm{mmol})$ in 2-methyl-2-propanol and $0.43 \mathrm{~mL}$ of 2-methyl-2-propanol $(4.64 \mathrm{mmol})$ and then the resulting mixture was heated under reflux for $3 \mathrm{~h}$ to afford $0.150 \mathrm{~g}$ of 182a $(0.21 \mathrm{mmol}, 72 \%)$ as a yellow solid: IR 1459, 822, $699 \mathrm{~cm}^{-1}$; ${ }^{1} \mathrm{H}$ NMR $\delta 8.24(2 \mathrm{H}, \mathrm{d}, J=9.6 \mathrm{~Hz}), 7.69(2 \mathrm{H}, \mathrm{d}, J=7.8 \mathrm{~Hz}), 7.68(1 \mathrm{H}, \mathrm{s}), 7.47(2 \mathrm{H}, \mathrm{d}, J=$ 
$9.0 \mathrm{~Hz}), 7.21(2 \mathrm{H}, \mathrm{t}, J=7.8 \mathrm{~Hz}), 7.17(4 \mathrm{H}, \mathrm{t}, J=8.4 \mathrm{~Hz}), 6.99(4 \mathrm{H}, \mathrm{d}, J=8.4 \mathrm{~Hz}), 6.74(2$ $\mathrm{H}, \mathrm{t}, J=8.4 \mathrm{~Hz}), 6.58(2 \mathrm{H}, \mathrm{d}, J=7.8 \mathrm{~Hz}), 6.44(1 \mathrm{H}, \mathrm{s}), 4.47(4 \mathrm{H}, \mathrm{s}), 1.83(18 \mathrm{H}, \mathrm{s}) ;{ }^{13} \mathrm{C}$ NMR $\delta 143.6,140.7,140.4,139.2,139.0,138.7,132.9,132.4,131.3,131.0,130.7,130.3$, 129.2, 127.3, 126.4, 125.7, 125.1, 122.8, 39.9, 38.5, 34.0; MS $m / z 718\left(\mathrm{M}^{+}\right), 551$; HRMS calcd for $\mathrm{C}_{56} \mathrm{H}_{46} 718.3594$, found 718.3594 .

182b. The same procedure was repeated as described for $167 \mathbf{a}$ except that a solution of 0.024 $\mathrm{g}$ of $181 \mathrm{~b}(0.03 \mathrm{mmol})$ in $10 \mathrm{~mL}$ of anhydrous $p$-xylene was treated with $0.03 \mathrm{~mL}$ of a $1.0 \mathrm{M}$ solution of potassium $t$-butoxide $(0.03 \mathrm{mmol})$ in 2-methyl-2-propanol and $0.02 \mathrm{~mL}$ of 2-methyl-2-propanol $(0.16 \mathrm{mmol})$ and then the resulting mixture was heated under reflux for $5 \mathrm{~h}$ to afford $0.017 \mathrm{~g}$ of $\mathbf{1 8 2 b}(0.02 \mathrm{mmol}, 73 \%)$ as a yellow solid: IR $1459,699 \mathrm{~cm}^{-1} ;{ }^{1} \mathrm{H}$ NMR $\delta 8.25(2 \mathrm{H}, \mathrm{d}, J=9.6 \mathrm{~Hz}), 7.69(2 \mathrm{H}, \mathrm{d}, J=7.8 \mathrm{~Hz}), 7.64(1 \mathrm{H}, \mathrm{s}), 7.48(2 \mathrm{H}, \mathrm{d}, J=$ $9.6 \mathrm{~Hz}), 7.29(2 \mathrm{H}, \mathrm{d}, J=8.4 \mathrm{~Hz}), 6.93(2 \mathrm{H}, \mathrm{q}, J=8.4 \mathrm{~Hz}), 6.72(2 \mathrm{H}, \mathrm{qd}, J=9.6,1.2 \mathrm{~Hz})$, $6.64(1 \mathrm{H}, \mathrm{s}), 4.45(2 \mathrm{H}, \mathrm{d}, J=21.6 \mathrm{~Hz}), 4.42(2 \mathrm{H}, \mathrm{d}, J=21.6 \mathrm{~Hz}), \quad$ AB pattern for $\mathrm{CH}_{2}$, $1.83(18 \mathrm{H}, \mathrm{s}), 1.50(6 \mathrm{H}, \mathrm{s}), 1.28(6 \mathrm{H}, \mathrm{s}), 0.85(18 \mathrm{H}, \mathrm{s})$; MS m/z $942\left(\mathrm{M}^{+}\right)$; HRMS calcd for $\mathrm{C}_{72} \mathrm{H}_{78}$ 942.6098, found 942.6150.

185. The same procedure was repeated as described for 167a except that a solution of 0.155 $\mathrm{g}$ of $184(0.19 \mathrm{mmol})$ in $10 \mathrm{~mL}$ of anhydrous toluene was treated with $0.40 \mathrm{~mL}$ of a $1.0 \mathrm{M}$ solution of potassium $t$-butoxide $(0.40 \mathrm{mmol})$ in 2-methyl-2-propanol and $0.15 \mathrm{~mL}$ of 2-methyl-2-propanol (3.03 $\mathrm{mmol})$ and then the resulting mixture was heated under reflux for $3.5 \mathrm{~h}$ to afford $0.109 \mathrm{~g}$ of $185(0.13 \mathrm{mmol}, 70 \%)$ as a yellow solid: IR $1365,829 \mathrm{~cm}^{-1} ;{ }^{1} \mathrm{H}$ NMR $\delta 8.26(2 \mathrm{H}, \mathrm{d}, J=9.0 \mathrm{~Hz}), 7.72\left(2 \mathrm{H}, \mathrm{d}, J=7.2 \mathrm{~Hz},-20^{\circ} \mathrm{C}\right), 7.71(1 \mathrm{H}, \mathrm{s}), 7.68(2 \mathrm{H}$, d, $J=7.7 \mathrm{~Hz}), 7.67(2 \mathrm{H}, J=9.0 \mathrm{~Hz}), 7.48(2 \mathrm{H}, \mathrm{d}, J=7.2 \mathrm{~Hz}), 7.47(2 \mathrm{H}, \mathrm{d}, J=9.0 \mathrm{~Hz})$, $7.18(2 \mathrm{H}, \mathrm{d}, J=8.4 \mathrm{~Hz}), 6.94(2 \mathrm{H}, \mathrm{td}, J=7.2,1.2 \mathrm{~Hz}), 6.60\left(2 \mathrm{H}, \mathrm{t}, J=7.2 \mathrm{~Hz},-20{ }^{\circ} \mathrm{C}\right)$, $6.57(2 \mathrm{H}, \mathrm{td}, J=7.8,1.2 \mathrm{~Hz}), 6.40(1 \mathrm{H}, \mathrm{s}), 6.35(2 \mathrm{H}, \mathrm{t}, J=7.8 \mathrm{~Hz}), 6.13(2 \mathrm{H}, \mathrm{t}, J=7.2 \mathrm{~Hz}$, $\left.-20{ }^{\circ} \mathrm{C}\right), \quad 5.71\left(2 \mathrm{H}, \mathrm{d}, J=7.2 \mathrm{~Hz},-20{ }^{\circ} \mathrm{C}\right), 4.48(4 \mathrm{H}, \mathrm{q}, J=21.0 \mathrm{~Hz}), 1.84(18 \mathrm{H}, \mathrm{s}) ;{ }^{13} \mathrm{C}$ NMR $\delta 143.7,139.3,138.98,138.89,138.4,138.1,133.4,132.8,130.5,130.3,130.20$, $130.17,130.1,127.5,126.9,125.6,125.3,124.6,124.0,123.8,121.8,120.8,119.4,39.6$, 38.2, 33.6; MS $m / z 818\left(\mathrm{M}^{+}\right), 761,650$; HRMS calcd for $\mathrm{C}_{64} \mathrm{H}_{50} 818.3907$, found 818.3916.

Aryl Ketone 196a. The same procedure was repeated as described for 160b except that 
$0.999 \mathrm{~g}(4.62 \mathrm{mmol})$ of 2,7-naphthalenedicarboxylic acid (195a) was heated with $40 \mathrm{~mL}$ of thionyl chloride under reflux for $12 \mathrm{~h}$ to furnish the crude 2,7-naphthalenedicarbonyl chloride. The acid chloride was treated with $t$-butylcopper, prepared from $2.09 \mathrm{~g}$ of $\mathrm{CuBr} \cdot \mathrm{SMe}_{2}(10.1 \mathrm{mmol})$ and $6.0 \mathrm{~mL}$ of a $1.7 \mathrm{M}$ solution of $t$-butyllithium $(10.2 \mathrm{mmol})$ in pentane, to afford $0.945 \mathrm{~g}$ of 196a (3.19 mmol, 69\%) as a white solid: IR 1671, 1477, 851 $\mathrm{cm}^{-1}$; ${ }^{1} \mathrm{H}$ NMR $\delta 8.27(2 \mathrm{H}, \mathrm{s}), 7.88(2 \mathrm{H}, \mathrm{d}, J=8.7 \mathrm{~Hz}), 7.85(2 \mathrm{H}, \mathrm{d}, J=8.7 \mathrm{~Hz}) ;{ }^{13} \mathrm{C} \mathrm{NMR}$ $\delta 208.7,136.5,135.0,131.3,129.4,127.6,126.6,44.4,28.1 ; \mathrm{MS} m / z 212\left(\mathrm{M}^{+}\right), 155,127$.

Aryl Ketone 196b. The same procedure was repeated as described for 160b except that $0.149 \mathrm{~g}(0.56 \mathrm{mmol})$ of 3,6-phenanthrenedicarboxylic acid (195b) was heated with $17 \mathrm{~mL}$ of thionyl chloride under reflux for $12 \mathrm{~h}$ to furnish the crude 3,6-phenanthrenedicarbonyl chloride. The acid chloride was treated with $t$-butylcopper, prepared from $0.254 \mathrm{~g}$ of $\mathrm{CuBr} \cdot \mathrm{SMe}_{2}(1.23 \mathrm{mmol})$ and $0.73 \mathrm{~mL}$ of a $1.7 \mathrm{M}$ solution of $t$-butyllithium $(1.23 \mathrm{mmol})$ in pentane, to afford $0.083 \mathrm{~g}$ of $\mathbf{1 9 6 b}(0.24 \mathrm{mmol}, 43 \%)$ as an orange solid: IR 1669, 1770, 852 $\mathrm{cm}^{-1} ;{ }^{1} \mathrm{H}$ NMR $\delta 9.05(2 \mathrm{H}, \mathrm{s}), 7.95(2 \mathrm{H}, \mathrm{dd}, J=8.4,1.5 \mathrm{~Hz}), 7.88(2 \mathrm{H}, \mathrm{d}, J=8.2 \mathrm{~Hz}), 7.79$ (2 H, s), 1.47 (18 H, s); ${ }^{13} \mathrm{C}$ NMR $\delta 208.8,136.6,133.4,129.7,128.3,128.0,125.8,122.9$, $44.3,28.2$.

Propargylic Alcohol 197a. The same procedure was repeated as described for 165a except that $0.498 \mathrm{~g}$ of $196 \mathrm{a}(1.68 \mathrm{mmol})$ was treated with lithium acetylide 46 prepared from 0.748 $\mathrm{g}$ of 1-ethynyl-2-(phenylethynyl)benzene $(3.70 \mathrm{mmol})$ and $1.5 \mathrm{~mL}$ of a $2.5 \mathrm{M}$ solution of $n$-butyllithium (3.70 mmol) in hexanes, to afford $1.12 \mathrm{~g}$ of $197 \mathrm{a}$ (1.58 $\mathrm{mmol}, 95 \%$ yield, $1: 1$ mixture of diastereomers) as a white solid: Diastereomer 1: IR 3545, 1477, $848 \mathrm{~cm}^{-1} ;{ }^{1} \mathrm{H}$ NMR $\delta 8.28(2 \mathrm{H}, \mathrm{s}), 8.00(2 \mathrm{H}, \mathrm{d}, J=8.7 \mathrm{~Hz}), 7.70(2 \mathrm{H}, \mathrm{d}, J=8.7 \mathrm{~Hz}), 7.66-7.59(4 \mathrm{H}, \mathrm{m})$, 7.43-7.15 (14 H, m), $2.68(2 \mathrm{H}, \mathrm{s}), 1.24(18 \mathrm{H}, \mathrm{s}) ;{ }^{13} \mathrm{C}$ NMR $\delta 139.8,132.2,132.1,131.8$, $131.6,128.3,128.1,127.9,126.9,126.5,125.8,125.0,122.8,96.3,93.3,88.3,84.7,79.6$, 39.9, 25.6. Diastereomer 2: IR 3568, 2250, 1477, $848 \mathrm{~cm}^{-1}$; ${ }^{1} \mathrm{H}$ NMR $\delta 8.21(2 \mathrm{H}, \mathrm{s}), 7.89$ (2 H, dd, $J=8.9,1.7 \mathrm{~Hz}), 7.65(2 \mathrm{H}, \mathrm{d}, J=8.7 \mathrm{~Hz}), 7.59(1 \mathrm{H}, \mathrm{d}, J=2.0, \mathrm{~Hz}), 7.56(2 \mathrm{H}, \mathrm{m})$, $7.53(1 \mathrm{H}, \mathrm{d}, J=2.0, \mathrm{~Hz}), 7.37-7.11(14 \mathrm{H}, \mathrm{m}), 2.50(2 \mathrm{H}, \mathrm{s}), 1.11(18 \mathrm{H}, \mathrm{s}) ;{ }^{13} \mathrm{C} \mathrm{NMR} \delta$ $139.9,132.2$, 132.1, 131.9, 131.6, 128.2, 128.1, 127.9, 127.1, 126.4, 125.9, 125.1, 122.9, $96.3,93.3,88.2,84.7,79.6,40.0,25.7$. 
Propargylic Alcohol 197b. The same procedure was repeated as described for 165a except that $0.102 \mathrm{~g}$ of $\mathbf{1 9 6 b}(0.33 \mathrm{mmol})$ was treated with lithium acetylide 46 prepared from 0.079 $\mathrm{g}$ of 1-ethynyl-2-(phenylethynyl)benzene $(0.39 \mathrm{mmol})$ and $0.16 \mathrm{~mL}$ of a $2.5 \mathrm{M}$ solution of $n$-butyllithium in hexanes, to afford $1.12 \mathrm{~g}$ of 197a (1.58 mmol, 95\% yield, 1:1 mixture of diastereomers) as a white solid: Diastereomer 1: IR 3540, 3452, 2249, 2215, 1494, $754 \mathrm{~cm}^{-1}$; ${ }^{1} \mathrm{H}$ NMR $\delta 9.13(2 \mathrm{H}, \mathrm{d}, J=1 \mathrm{~Hz}), 8.02(2 \mathrm{H}, \mathrm{d}, J=8.4 \mathrm{~Hz}), 7.71(2 \mathrm{H}, \mathrm{d}, J=9.4 \mathrm{~Hz}), 7.70$ (2 H, s), 7.59-7.55 (4 H, m), 7.41-7.38 (4 H, m), 7.33-7.30 (4 H, m), 7.23-7.16 (4 H, m), $2.72(2 \mathrm{H}, \mathrm{s}), 1.13(18 \mathrm{H}, \mathrm{s}) ;{ }^{13} \mathrm{C}$ NMR $\delta 140.4,132.3,132.1,131.6,131.3,129.4,128.3$, $128.1,128.0,127.1,126.7,126.5,125.8,125.0,122.9$, 121.4, 96.3, 93.2, 88.3, 84.9, 79.9, 39.9, 25.6. Diastereomer 2: IR 3548, 2248, 2216, 1494, 754; ${ }^{1} \mathrm{H}$ NMR $\delta 9.14$ (2 H, s), 8.06 (2 H, dd, $J=8.1,1.2 \mathrm{~Hz}), 7.71(2 \mathrm{H}, \mathrm{d}, J=8.2 \mathrm{~Hz}), 7.70(2 \mathrm{H}, \mathrm{s}), 7.62-7.58(4 \mathrm{H}, \mathrm{m})$, 7.43-7.40 (4H, m), 7.35-7.30 (4 H, m), 7.29-7.16 (2 H, m), $2.68(2 \mathrm{H}, \mathrm{s}), 1.18(18 \mathrm{H}, \mathrm{s}) ;{ }^{13} \mathrm{C}$ NMR $\delta 140.5,132.3,132.1,131.6,131.3,129.4,128.3,128.1,127.9,127.1,127.0,126.5$, $125.8,125.0,122.9,121.2,96.3,93.2,88.3,85.0,79.8,39.9,25.6$.

Benzannulated Enediyne 198a. The same procedure was repeated as described for 166a except that $0.649 \mathrm{~g}$ of 197a $(0.93 \mathrm{mmol})$ was treated with $0.323 \mathrm{~g}$ of triethylsilane $(2.78$ $\mathrm{mmol})$ and $0.58 \mathrm{~mL}$ of trifluoroacetic acid $(0.845 \mathrm{~g}, 7.41 \mathrm{mmol})$ in $10 \mathrm{~mL}$ methylene chloride to afford $0.496 \mathrm{~g}$ of $\mathbf{1 9 8 a}(0.74 \mathrm{mmol}, 80 \%$ yield, $1: 1$ mixture of diastereomers $)$ as a yellow solid: IR 2216, 1494, $845 \mathrm{~cm}^{-1} ;{ }^{1} \mathrm{H}$ NMR $\delta 7.77$ (2 H, s), $7.74(2 \mathrm{H}, \mathrm{s}), 7.66-7.47$ (16 H, m), 7.33-7.18 (20 H, m), 7.15-7.09 (8H, m), 3.86 (2 H, s), $3.82(2 \mathrm{H}, \mathrm{s}), 1.11(18 \mathrm{H}, \mathrm{s})$, $1.10(18 \mathrm{H}, \mathrm{s}) ;{ }^{13} \mathrm{C}$ NMR $\delta 136.92,136.87,132.65,132.57,132.1,132.0,131.6,131.4,128.4$, $128.15,128.12,128.07,127.91,127.86,127.4,126.7,126.6,126.3,125.67,125.62,123.16$, $123.12,95.6,92.9,88.6,88.5,82.6,82.58,50.8,50.7,35.7,27.9$

Benzannulated Enediyne 198b. The same procedure was repeated as described for 166a except that $0.140 \mathrm{~g}$ of $197 \mathrm{~b}(0.19 \mathrm{mmol})$ was treated with $0.066 \mathrm{~g}$ of triethylsilane $(0.57$ $\mathrm{mmol})$ and $0.173 \mathrm{~g}$ of triethylsilane $(1.52 \mathrm{mmol})$ in $10 \mathrm{~mL}$ methylene chloride to afford $0.111 \mathrm{~g}$ of $198 \mathrm{~b}(0.15 \mathrm{mmol}, 83 \%$ yield, $1: 1$ mixture of diastereomers) as a yellow solid: IR 2217, 1493, $753 \mathrm{~cm}^{-1} ;{ }^{1} \mathrm{H}$ NMR $\delta 8.80(2 \mathrm{H}, \mathrm{s}), 8.67(2 \mathrm{H}, \mathrm{s}), 7.85-7.74(8 \mathrm{H}, \mathrm{m}), 7.70(4 \mathrm{H}$, s), 7.63-7.54 (10 H, m), $7.41(10 \mathrm{H}, \mathrm{m}), 7.33-7.21(12 \mathrm{H}, \mathrm{m}), 7.19-7.12(8 \mathrm{H}, \mathrm{m}), 4.01(2 \mathrm{H}$, 
s), $4.01(2 \mathrm{H}, \mathrm{s}), 1.19(18 \mathrm{H}, \mathrm{s}), 1.17(18 \mathrm{H}, \mathrm{s}) ;{ }^{13} \mathrm{C}$ NMR $\delta 137.6,137.5,132.13,132.09$, $132.03,131.6,130.95,130.91,129.60,129.56,128.33$, 128.30, 128.2, 128.1, 128.0, 127.88, $127.86,127.7,127.4,126.2,125.62,125.57,123.6,123.5,123.11,123.06,95.7,95.6,92.9$, $92.8,88.7,88.5,82.81,82.80,51.1,50.9,35.74,35.69,27.9$.

1,12-Diphenylbenzo[c]phenanthrene 204a. The same procedure was repeated as described for 167a except that a solution of $0.101 \mathrm{~g}$ of 198a $(0.15 \mathrm{mmol})$ in $10 \mathrm{~mL}$ of anhydrous toluene was treated with $0.32 \mathrm{~mL}$ of a $1.0 \mathrm{M}$ solution of potassium $t$-butoxide $(0.32 \mathrm{mmol})$ in 2-methyl-2-propanol and $0.23 \mathrm{~mL}$ of 2-methyl-2-propanol $(2.41 \mathrm{mmol})$ and then the resulting mixture was heated under reflux for $3 \mathrm{~h}$ to afford $0.010 \mathrm{~g}$ of 204a $(0.01 \mathrm{mmol}, 10 \%)$ as a yellow solid: IR 1600, $842 \mathrm{~cm}^{-1} ;{ }^{1} \mathrm{H}$ NMR $\delta 8.09(2 \mathrm{H}, \mathrm{d}, J=8.7 \mathrm{~Hz}), 7.91-7.86(2 \mathrm{H}$, m), $7.41(2 \mathrm{H}, \mathrm{d}, J=7.4 \mathrm{~Hz}), 7.40(2 \mathrm{H}, \mathrm{d}, J=8.6 \mathrm{~Hz}), 7.08(2 \mathrm{H}, \mathrm{t}, J=7.4 \mathrm{~Hz}), 6.98-6.95$ $(4 \mathrm{H}, \mathrm{m}), 6.79(2 \mathrm{H}, \mathrm{t}, J=7.2 \mathrm{~Hz}), 6.76(2 \mathrm{H}, \mathrm{t}, J=7.2 \mathrm{~Hz}), 6.30(2 \mathrm{H}, \mathrm{d}, J=8.2 \mathrm{~Hz}), 5.70(2$ $\mathrm{H}, \mathrm{d}, J=7.7 \mathrm{~Hz}), 4.26(2 \mathrm{H}, \mathrm{d}, J=21.0 \mathrm{~Hz}), 4.10(2 \mathrm{H}, \mathrm{d}, J=21.0 \mathrm{~Hz}), 1.74(18 \mathrm{H}, \mathrm{s}) ;{ }^{13} \mathrm{C}$ NMR $\delta 144.4,140.8,140.3,138.5,137.9,137.0,134.9,134.4,131.5,131.4,130.8,127.9$, $126.5,126.1,125.9,125.8,125.3,123.8,123.0,120.0,39.6,37.9,33.2 ; \mathrm{m} / z 668\left(\mathrm{M}^{+}\right), 551$. HRMS calcd for $\mathrm{C}_{52} \mathrm{H}_{44}$ 668.3438, found 668.3433. Recrystallization of 204a from $\mathrm{CH}_{2} \mathrm{Cl}_{2} /$ hexanes produced a crystal suitable for X-ray structure analysis.

1,14-Diphenyldibenzo[c,g]phenanthrene 204b. The same procedure was repeated as described for 167a except that a solution of $0.029 \mathrm{~g}$ of $198 \mathrm{~b}(0.040 \mathrm{mmol})$ in $10 \mathrm{~mL}$ of anhydrous toluene was treated with $0.09 \mathrm{~mL}$ of a $1.0 \mathrm{M}$ solution of potassium $t$-butoxide (0.09 mmol) in 2-methyl-2-propanol and $0.07 \mathrm{~mL}$ of 2-methyl-2-propanol $(0.64 \mathrm{mmol})$ and then the resulting mixture was heated under reflux for $3 \mathrm{~h}$ to afford $0.014 \mathrm{~g}$ of $\mathbf{2 0 4 b}(0.019$ mmol, 47\%) as a yellow solid: IR 1465, $731 \mathrm{~cm}^{-1} ;{ }^{1} \mathrm{H}$ NMR $\delta 8.05(2 \mathrm{H}, \mathrm{d}, J=9.2 \mathrm{~Hz}), 7.82$ $(2 \mathrm{H}, \mathrm{s}), 7.40(2 \mathrm{H}, \mathrm{d}, J=8.9 \mathrm{~Hz}), 7.36(2 \mathrm{H}, \mathrm{d}, J=7.4 \mathrm{~Hz}), 6.99(4 \mathrm{H}, \mathrm{m}), 6.81$ (4 H, m), $6.64(2 \mathrm{H}, \mathrm{t}, J=7.4 \mathrm{~Hz}), 6.20\left(4 \mathrm{H}, \mathrm{d}, J=6.9 \mathrm{~Hz}\right.$, at $\left.85^{\circ} \mathrm{C}\right), 5.19(2 \mathrm{H}, \mathrm{d}, J=8.2 \mathrm{~Hz}), 4.45$ $(2 \mathrm{H}, \mathrm{d}, J=20.0 \mathrm{~Hz}), 4.22(2 \mathrm{H}, \mathrm{d}, J=20.0 \mathrm{~Hz}), 1.91(18 \mathrm{H}, \mathrm{s}) ; m / z 718\left(\mathrm{M}^{+}\right), 661$. HRMS calcd for $\mathrm{C}_{56} \mathrm{H}_{46} 718.3594$, found 718.3561. Recrystallization of 204b from $\mathrm{CH}_{2} \mathrm{Cl}_{2} /$ hexanes produced a crystal suitable for X-ray structure analysis. 


\section{References}

1. (a) Myers, A. G.; Kuo, E. Y.; Finney, N. S. J. Am. Chem. Soc. 1989, 111, 8057-8059. (b) Myers, A. G.; Dragovich, P. S. J. Am. Chem. Soc. 1989, 111, 9130-9132. (c) Myers, A. G.; Dragovich, P. S.; Kuo, E. Y. J. Am. Chem. Soc. 1992, 114, 9369-9386. (d) Nagata, R.; Yamanaka, H.; Okazaki, E.; Saito, I. Tetrahedron Lett. 1989, 30, 4995-4998. (e) Nagata, R.; Yamanaka, H.; Murahashi, E.; Saito, I. Tetrahedron Lett. 1990, 31, 2907-2910.

2. (a) Schmittel, M.; Strittmatter, M.; Kiau, S. Tetrahedron Lett. 1995, 36, 4975-4978. (b) Schmittel, M.; Strittmatter, M.; Vollmann, K.; Kiau, S. Tetrahedron Lett. 1996, 37, 999-1002. (c) Schmittel, M.; Strittmatter, M.; Kiau, S. Angew. Chem. Int. Ed. Engl. 1996, 35, 1843-1845. (d) Schmittel, M.; Kiau, S.; Siebert, T.; Strittmatter, M. Tetrahedron Lett. 1996, 37, 7691-7694. (e) Schmittel, M.; Steffen, J.-P.; Mayward, M.; Engels, B.; Helten, H.; Musch, P. J. Chem. Soc. Perkin Trans. 2 2001, 1331-1339.

3. (a) Jones, R.R.; Bergman, R. G. J. Am. Chem. Soc. 1972, 94, 660-661. (b) Bergman, R. G. Acc. Chem. Res. 1973, 6, 25-31. (c) Lockhart, T. P.; Bergman, R. G. J. Am. Chem. Soc. 1981, 103, 4091-4096.

4. (a) Sullivan, R. W.; Coghlan, V. M.; Munk, S. A.; Reed, M. W.; Moore, H. W. J. Org. Chem. 1994, 59, 2276-2278. (b) Foland, L. D.; karlsson, J. O.; Perri, S. T.; Schwabe, R.; Xu, X. L.; Patil, S.; Moore, H. W. J. Am. Chem. Soc. 1989, 111, 975-989. (c) Reed, M. W.; Pollart, D. J.; Perri, S. T.; Foland, L. D.; Moore, H. W. J. Org. Chem. 1988, 53, 2477-2482. (d) Perri, S. T.; Foland, L. D.; Moore, H. W. Tetrahedron Lett. 1988, 29, 3529-3532. (e) Xia, H.; Moore, H. W. J. Org. Chem. 1992, 57, 3765-3766.

5. (a) Myers, A. G. Tetrahedron Lett. 1987, 28, 4493-4496. (b) Myers, A. G.; Proteau, P. J. J. Am. Chem. Soc. 1988, 110, 7212-7214. (c) Myers, A. G.; Proteau, P. J. J. Am. Chem. Soc. 1989, 111, 1146-1147.

6. (a) Zein, N.; McGahren, W. J.; Morton, G. O.; Ashcroft, J.; Ellestad, G. A. J. Am. Chem. Soc. 1989, 111, 6888-6890. (b) De Voss, J. J.; Hangeland, J. J.; Townsend, C. A. J. Am. Chem. Soc. 1990, 112, 4554-4556.

7. Chen, W.; Zou, J.; Yu, C. J. Org. Chem. 2003, 68, 3663-3672.

8. (a) Shi, C.; Wang, K. K. J. Org. Chem. 1998, 63, 3517-3520. (b) Shi, C.; Zhang, Q.; Wang, K. K. J. Org. Chem. 1999, 64, 925-932. (c) Schmittel, M.; Steffen, J. P.; 
Wencesla-Angel, M. A.; Engels, B.; Lennartz, C.; Hanrath, M. Angew. Chem. Int. Ed. Engl. 1998, 37, 1562-1564. (d) Schmittel, M.; Steffen, J. P.; Engels, B.; Lennartz, C.; Hanrath, M. Angew. Chem. Int. Ed. Engl. 1998, 37, 2371-2373.

9. Schmittel, M.; Mayward, M. Chem. Commun. 2001, 155-156.

10. Schmittel, M.; Vavilala, C. J. Org. Chem. 2005, 127, 4865-4868.

11. (a) Schmittel, M.; Kiau, S.; Siebert, T.; Strittmatter, M. Tetrahedron Lett. 1996, 37, 7691-7694. (b) Schmittel, M.; Mayward, M.; Strittmatter, M. Synlett 1997, 165-166.

12. Engels, B.; Lennartz, C.; Hanrath, M.; Schmittel, M.; Strittmatter, M. Angew. Chem. Int. Ed. Engl. 1998, 37, 1960-1963

13. Schmittel, M.; Mahajan, A. A.; Bucher, G. J. Am. Chem. Soc. 2005, 127, 5324-5325.

14. (a) de Frutos, Ó.; Echavarren, A. M. Tetrahedron Lett. 1997, 38, 7941-7942. (b) Wang,

K. K.; Zhang, H. R.; Petersen, J. L. J. Org. Chem. 1999, 64, 1650-1656.

15. (a) Schmittel, M.; Rodríguez, D.; Steffen, J. P. Angew. Chem. Int. Ed. Engl. 2000, 39, 2152-2155. (b) Li, H.; Petersen, J. L.; Wang, K. K. J. Org. Chem. 2003, 68, 5512-5518.

16. (a) Zhang, H. R.; Wang, K. K. J. Org. Chem. 1999, 64, 7996-7999. (b) Li, H.; Zhang, H.

R.; Petersen, J. L.; Wang, K. K. J. Org. Chem. 2001, 66, 6662-6668.

17. Li, H.; Petersen, J. L.; Wang, K. K. J. Org. Chem. 2001, 66, 7804-7810.

18. (a) Lu, X.; Petersen, J. L.; Wang, K. K. J. Org. Chem. 2002, 67, 5412-5415. (b) Lu, X.;

Petersen, J. L.; Wang, K. K. J. Org. Chem. 2002, 67, 7797-7801.

19. For an excellent review, see: Krause, N.; Hashmi, A. S. K. Modern Allene Chemistry Wiley-VCH, 2004, Vol. 2, p1091-1126.

20. Myers, A. G.; Finney, N. S.; Kuo, E. Y. Tetrahedron Lett. 1989, 30, 5747-5750.

21. (a) Gillmann, T.; Hülsen, Y.; Massa, W.; Wocadlo, S. Synlett 1995, 1257-1259. (b) Gillmann, T.; Heckhoff, S.; Weeber, T. Syn. Commun. 1994, 24, 2133-2138.

22. Dopico, P. G.; Finn, M. G. Tetrahedron 1999, 55, 29-62

23. Wu, M.-J.; Lin, C.-F.; Wu, J.-S.; Chen, H.-T. Tetrahedron Lett. 1994, 35, 1879-1882.

24. Sevin, A.; Chodkiewicz, W. Tetrahedron Lett. 1967, 2975-2980.

25. Nicolaou, K. C.; Maligres, P.; Shin, J.; de Leon, E.; Rideout, D. J. Am. Chem. Soc. 1990, $112,7825-7826$. 
26. (a) Grissom, J. W.; Huang, D. J. Org. Chem. 1994, 59, 5114-5116. (b) Grissom, J. W.; Klingberg, D.; Huang, D.; Slattery, B. J. Org. Chem. 1997, 62, 603-606.

27. Cunico, R. F.; Nair, S. K. Tetrahedron Lett. 1997, 38, 25-28.

28. Brunette, S. R.; Lipton, M. A. J. Org. Chem. 2000, 65, 5114-5119.

29. (a) Andemichael, Y. M.; Gu, Y.-G.; Wang, K. K. J. Org. Chem. 1992, 57, 794-796. (b) Wang, K. K.; Wang, Z. Tetrahedron Lett. 1994, 35, 1829-1832. (c) Wang, Z.; Wang, K. K. J. Org. Chem. 1994, 59, 4738-4742. (d) Wang, K. K.; Liu, B.; Lu, Y.-D. Tetrahedron Lett. 1995, 36, 3785-3788. (e) Wang, K. K.; Wang, Z.; Sattsangi, P. D. J. Org. Chem. 1996, 61, 1516-1518. (f) Liu, B.; Wang, K. K.; Petersen, J. L. J. Org. Chem. 1996, 61, $8503-8507$.

30. Zhang, H. -R. Ph. D. Thesis, West Virginia University 2000.

31. (a) Barth, W. E.; Lawton, R. G. J. Am. Chem. Soc. 1966, 88, 380-381. (b) Barth, W. E.; Lawton, R. G. J. Am. Chem. Soc. 1971, 93, 1730-1745.

32. (a) Yang, C. X.; Harvey, R. G. Polycyclic Aromat. Compd. 1992, 2, 229-233. (b) Harvey, R. G.; Abu-Shqara, E.; Yang, C. J. Org. Chem. 1992, 57, 6313-6317. (c) Harvey, R. G. Polycyclic Aromatic Hydrocarbons; Wiley: New York, 1997; pp 336-337. (d) Bachmann, W. E.; Sheehan, J. C. J. Am. Chem. Soc. 1941, 63, 204-206. (e) Rutherford, K. G.; Newman, M. S. J. Am. Chem. Soc. 1957, 79, 213-214. (f) Medenwald, H. Chem. Ber. 1953, 86, 287-293. (g) Bhatt, T. S.; Coombs, M. M.; Kissonerghis, A.-M. J. Chem. Soc., Chem. Commun. 1979, 433-434. (h) Yoshida, M.; Minabe, M.; Suzuki, K. Bull. Chem. Soc. Jpn. 1983, 56, 2179-2180. (i) Minabe, M.; Yoshida, M.; Takayanagi, T. Bull. Chem. Soc. Jpn. 1988, 61, 995-996. (j) Tomioka, H.; Kobayashi, N. Bull. Chem. Soc. Jpn. 1991, 64, 327-329. (k) Sieglitz, A.; Schidlo, W. Chem. Ber. 1963, 96, 1098-1108.

33. Han, X. Master Thesis, West Virginia University 2001.

34. Jeong, I.-Y.; Lee, W. S.; Goto, S.; Sano, S.; Shiro, M.; Nagao, Y. Tetrahedron 1998, 54, $14437-14454$.

35. For recent reviews, see: (a) F. Vögtle, Fascinating Molecules in Organic chemistry, Wiley and Sons, New York, 1992, p 156. (b) H. Hopf. Classica in Hydrocarbon Chemistry, Wiley-VCh, Weinheim, 2000, p 321. 
36. (a) Verbiest, T.; Elshocht, S. V.; Kauranen, M.; Hellemans, L.; Snauwaert, J.; Nuckolls, C.; Katz, T. J.; Persoons, A. Science 1998, 282, 913-915. (b) Grimme, S.; Harren, J.; Sobanski, A.; Vögtle, F. Eur. J. Org. Chem. 1998, 1491-1509. (c) Chen, C.-T.; Chou, Y.-C. J. Am. Chem. Soc. 2000, 122, 7662-7672. (d) Nishida, J.-I.; Suzuki, T.; Ohkita, M.; Tsuji, T. Angew. Chem. Int. Ed. Engl. 2001, 40, 3251-3254. (e) Verbiest, T.; Sioncke, S.; Persoons, A.; Vyklický, L.; Katz, T. J. Angew. Chem. Int. Ed. Engl. 2002, 41, 3882-3884. (f) Nuckolls, C.; Shao, R.; Jang, W.-G.; Clark, N. A.; Walba, D. M.; Katz, T. J. Chem. Mater. 2002, 14, 773-776. (g) Maiorana, S.; Papagni, A.; Licandro, E.; Annunziata, R.; Paravidino, P.; Perdicchia, D.; Giannini, C.; Bencini, M.; Clays, K,; Persoon, A. Tetrahedron 2003, 59, 6481-6488. (h) Clays, K,; Wostyn, K,; Persoon, A.; Maiorana, S.; Papagni, A.; Daul, C. A.; Weber, V. Chem. Phys. Lett. 2003, 372, $438-442$.

37. (a) Tanaka, K.; Osuga, H.; Shogase, Y.; Suzuki, H. Tetrahedron Lett. 1995, 36, 915-918.

(b) Tanaka, K.; Kitahara, Y.; Suzuki, H.; Osuga, H. Tetrahedron Lett. 1996, 37, 5925-5928. (c) Reetz, M. T.; Beuttenmüller, E. W.; Goddard, R. Tetrahedron Lett. 1997, 38, 3211-3214. (d) Terfort, A.; Görls, H.; Brunner, H. Synthesis 1997, 79-86. (e) Fox, J. M.; Katz, T. J. J. Org. Chem. 1999, 64, 302-305. (f) Dreher, S. D.; Katz, T. J.; Lam, K.-C.; Rheingold, A. L. J. Org. Chem. 2000, 65, 815-822. (g) Sato, I.; Yamashima, R.; Kadowaki, K.; Yamamoto, J.; Shibata, T.; Soai, K. Angew. Chem. Int. Ed. 2001, 40, 1096-1098.

38. (a) Kim, Y. H. Science 1981, 213, 1379-1381. (b) Dipple, A.; Pigott, M. A.; Agarwal, S. K.; Yagi, H.; Sayer, J. M.; Jerina, D. M. Nature 1987, 327, 535-536. (c) Ihara, H.; Nakanishi, N.; Sagawa, H.; Hirayama, C.; Sakurai, T.; Kinoshita, T.; Tsujita, Y. Chem. Lett. 1998, 963-964. (d) Honzawa, S.; Okubo, H.; Anzai, S.; Yamaguchi, M.; Tsumoto, K.; Kumagai, I. Bioorg. Med. Chem. 2002, 10, 3213-3218. (e) Nakagawa, H.; Yoshida, M.; Koborl, Y.; Yamada, K.-I. Chirality 2003, 15, 703-708.

39. (a) Kelly, T. R.; Sestelo, J. P.; Tellitu, I. J. Org. Chem. 1998, 63, 3655-3665. (b) Kelly, T. R.; De Silva, H.; Silva, R. A. Nature 1999, 401, 150-152.

40. Newman, M. S.; Lednicer, D. J. Am. Chem. Soc. 1956, 78, 4765-4770.

41. (a) Flammang-Barbieux, M.; Nasielski, J.; Martin, R. H. Tetrahedron Lett.1967, 743-744. 
(b) Martin, R. H.; Marchant, M-J.; Baes, M. Helv. Chim. Acta 1971, 54, 358-360. (c) Martin, R. H.; Baes, M. Tetrahedron 1975, 31, 2135-2137. (d) Moradpour, A.; Kagan, H.; Baes, M.; Morren, G.; Martin, R. H. Tetrahedron 1975, 31, 2139-2143. (e) Hassine, B. B.; Gorsane, M.; Pecher, J. Bull. Soc. Chim. Belg. 1985, 94, 597-603. (f) Liu, L.; Yang, B.; Katz, T. J.; Poindexter, M. K. J. Org. Chem. 1991, 56, 3769-3775. (g) Frimer, A. A.; Kinder, J. D.; Youngs, W. J.; Meador, M. B. A. J. Org. Chem. 1995, 60, 1658-1664. (h) Fox, J. M.; Lin, D. J. Org. Chem. 1998, 63, 2031-2038. For reviews, see: (i) Laarhoven, W. H.; Prinsen, W. J. C. Top. Curr. Chem. 1984, 125, 63-130. (j) Meurer, K. P.; Vögtle, F. Top. Curr. Chem. 1985, 127, 1-76. (k) Hopf, H. Classics in Hydrocarbon Chemistry, Wiley-VCH, Weinheim, 2000, p 321-320.

42. (a) Liu, L.; Katz, T. J. Tetrahedron Lett. 1990, 31, 3983-3986. (b) Willmore, N. D.; Liu, L.; Katz, T. J. Angew. Chem. Int. Ed. 1992, 31, 1093-1095.

43. (a) Dubois, F.; Gingras, M. Tetrahedron Lett. 1998, 39, 5039-5040. (b) Gingras, M.; Dubois, F. Tetrahedron Lett. 1999, 40, 1309-1312.

44. (a) Harrowven, D. C.; Nunn, M. I. T.; Fenwick, D. R. Tetrahedron Lett. 2002, 43, 3189-3191. (b) Harrowven, D. C.; Nunn, M. I. T.; Fenwick, D. R. Tetrahedron Lett. 2002, 43, 7345-7347.

45. (a) Teplý, F.; Stará, I. G.; Srarý, I.; Kollárovič, A.; Śaman, D.; Rulǐšek, L.; Fiedler, P. J. Am. Chem. Soc. 2002, 124, 9175-9180. (b) Stará, I. G.; Srarý, I.; Kollárovič, A.; Teplý, F.; Śaman, D.; Fiedler, P. Collect. Czech. Chem. Commun. 2003, 68, 917-930. (c) Teplý, F.; Stará, I. G.; Srarý, I.; Kollárovič, A.; Śaman, D.; Vyskočil, Š.; Fiedler, P. J. Org. Chem. 2003, 68, 5193-5197.

46. (a) Han, S.; Bond, A. D.; Disch, R. L.; Holmes, D.; Schulman, J. M.; Teat, S. J.; Vollhardt, K. P. C.; Whitener, G. D. Angew. Chem. Int. Ed. 2002, 41, 3223-3227. (b) Han, S.; Anderson, D. R.; Bond, A. D.; Chu, H. V.; Disch, R. L.; Holmes, D.; Schulman, J. M.; Teat, S. J.; Vollhardt, K. P. C. Angew. Chem. Int. Ed. 2002, 41, 3227-3230.

47. (a) Carreňo, M. C.; Hernández-Sánchez, R.; Mahugo, J.; Urbano, A. J. Org. Chem. 1999, 64, 1387-1390. (b) Carreňo, M. C.; García-Cerrada, S.; Urbano, A. J. Am. Chem. Soc. 2001, 123, 7929-7930. (c) Carreňo, M. C.; García-Cerrada, S.; Sanz-Cuesta, M. J.; 
Urbano, A. Chem. Commun. 2001, 1452-1453. (d) Carreňo, M. C.; García-Cerrada, S.; Urbano, A. Chem. Commun. 2002, 1412-1413.

48. (a) Ogawa, Y.; Ueno, T.; Karikomi, M.; Seki, K.; Haga, K.; Uyehara, T. Tetrahedron Lett. 2002, 43, 7827-7829. (b) Ogawa, Y.; Toyama, M.; Karikomi, M.; Seki, K.; Haga, K.; Uyehara, T. Tetrahedron Lett. 2003, 44, 2167-2170.

49. Stará, I. G.; Alexandrová, Z.; Teplý, F.; Sehnal, P.; Starý, I.; Šaman, D.; Buděšínský, M.; Cvačka, J. Org Lett. 2005, 2547-2550.

50. Dai, W.; Petersen, J. L.; Wang, K. K. Org. Lett. 2004, 6, 4355-4357.

51. (a) Tinnemans, A. H. A.; Laarhoven, W. H. Tetrahedron Lett. 1973, 817-820. (b) Laarhoven, W. H.; Peters, W. H. M.; Tinnemans, A. H. A. Tetrahedron Lett. 1978, 34, 817-820. (c) Dickerman, S. C.; Zimmerman, I. J. Org. Chem. 1974, 39, 3429-3430.

52. Tinnemans, A. H. A.; Laarhoven, W. H. J. Am. Chem. Soc. 1974, 96, 4911-4616.

53. Žabjek, A.; Petrič, A. Tetrahedron Lett. 1999, 40, 6077-6078.

54. Newman, M. S.; Boden, H. J. Org. Chem. 1961, 26, 1759-1761.

55. Brooks, M. A.; Scott, L. T. J. Am. Chem. Soc. 1999, 121, 5444-5449.

56. Laarhoven, W. H.; Boumans, P. G. F. Recul. Trav. Chim. Pays-Bas 1975, 94, 114-118.

57. (a) Tinnemans, A. H. A.; Laarhoven, W. H. J. Chem. Soc., Perkin Trans. 2 1976, 1115-1120. (b) Tinnemans, A. H. A.; Laarhoven, W. H. J. Am. Chem. Soc. 1974, 96, $4617-4622$.

58. Nierenstein, M.; Webster, C. W. J. Am. Chem. Soc. 1945, 67, 691-692.

59. (a) Chardonnens, L.; Ritter, R. Helv. Chim. Acta 1955, 38, 393-396. (b) Chardonnens, L.; Chardonnens, H. Helv. Chim. Acta 1958, 41, 2109-2111. (c) Chardonnens, L.; Rody, J. Helv. Chim. Acta 1959, 42, 1328-1331. (d) Chardonnens, L.; Chardonnens, H. Helv. Chim. Acta 1968, 51, 1998-2005.

60. Hart, H.; Harada, K.; Du, C. J. F. J. Org. Chem. 1985, 50, 3104-3110.

61. Harnik, E.; Herbstein, F. H.; Schmidt, G. M. J. Nature 1951, 168, 158-160

62. Hirshfeld, F. L.; Sandler, S.; Schmidt, G. M. J. J. Chem. Soc. 1963, 2108-2125.

63. Newman, M. S.; Wise, R. M. J. Am. Chem. Soc. 1956, 78, 450-454.

64. (a) Newman, M. S.; Wolf, M. J. Am. Chem. Soc. 1952, 74, 3225-3228. (b) Okubo, H.; Yamaguchi, M.; Kabuto, C. J. Org. Chem. 1998, 63, 9500-9509. (c) Okubo, H.; Naisuke, 
D.; Anzai, S.; Yamaguchi, M. J. Org. Chem. 2001, 66, 557-563. (d) Nakano, D.; Hirano, R.; Yamaguchi, M.; Kabuto, C. Tetrahedron Lett. 2003, 44, 3683-3686 (e) Fields, D. L.; Regan, T. H. J. Heterocycl. Chem. 1973, 10, 195-199. (f) Laarhoven, W. H.; Boumans, P. G. F. J. Royal. Netherlans. Chem. Soc. 1975, 94, 114-119. (g) Yamamoto, K.; Ikeda, T.; Kitsuki, T.; Okamoto, Y.; Chikamatsu, H.; Nakazaki, M. J. Chem.Soc., Perkin Trans. 1 1990, 271-276. (h) Minuti, L.; Taticchi, A.; Marrocchi, A.; Gacs-Baitz, E.; Galeazzi, R. Eur. J. Org. Chem. 1999, 3155-3163.

65. Honzawa, S.; Okubo, H.; Nakamura, K.; Anzai, S.; Yamaguchi, M.; Kabuto, C. Tetrahedron: Asymmetry 2002, 13, 1043-1052.

66. Khalaf, A. I.; Pitt, A. R.; Scobie, M.; Suckling, C. J.; Urwin, J.; Waigh, R. D.; Fishleigh, R. U.; Young, S. C.; Wylie, W. A. Tetrahedron 2002, 13, 1043-1052.

67. Lakshman, M. K.; Kole, P. L.; Chaturvedi, S.; Saugier, J. H.; Yeh, H. J. C.; Glusker, J. P.; Carrell, H. L.; Katz, A. K.; Afshar, C. E.; Dashwood, W-M.; Kenniston, G.; Baird, W. M. J. Am. Chem. Soc. 2000, 122, 12629-12636.

68. (a) Kuroda, R. J. Chem. Soc., Perkin Trans. 2 1982, 789-794. (b) Frimer, A. A.; Kinder, J. D.; Youngs, W. J.; Meador, M. A. B. J. Org. Chem. 1995, 60, 1658-1664. 


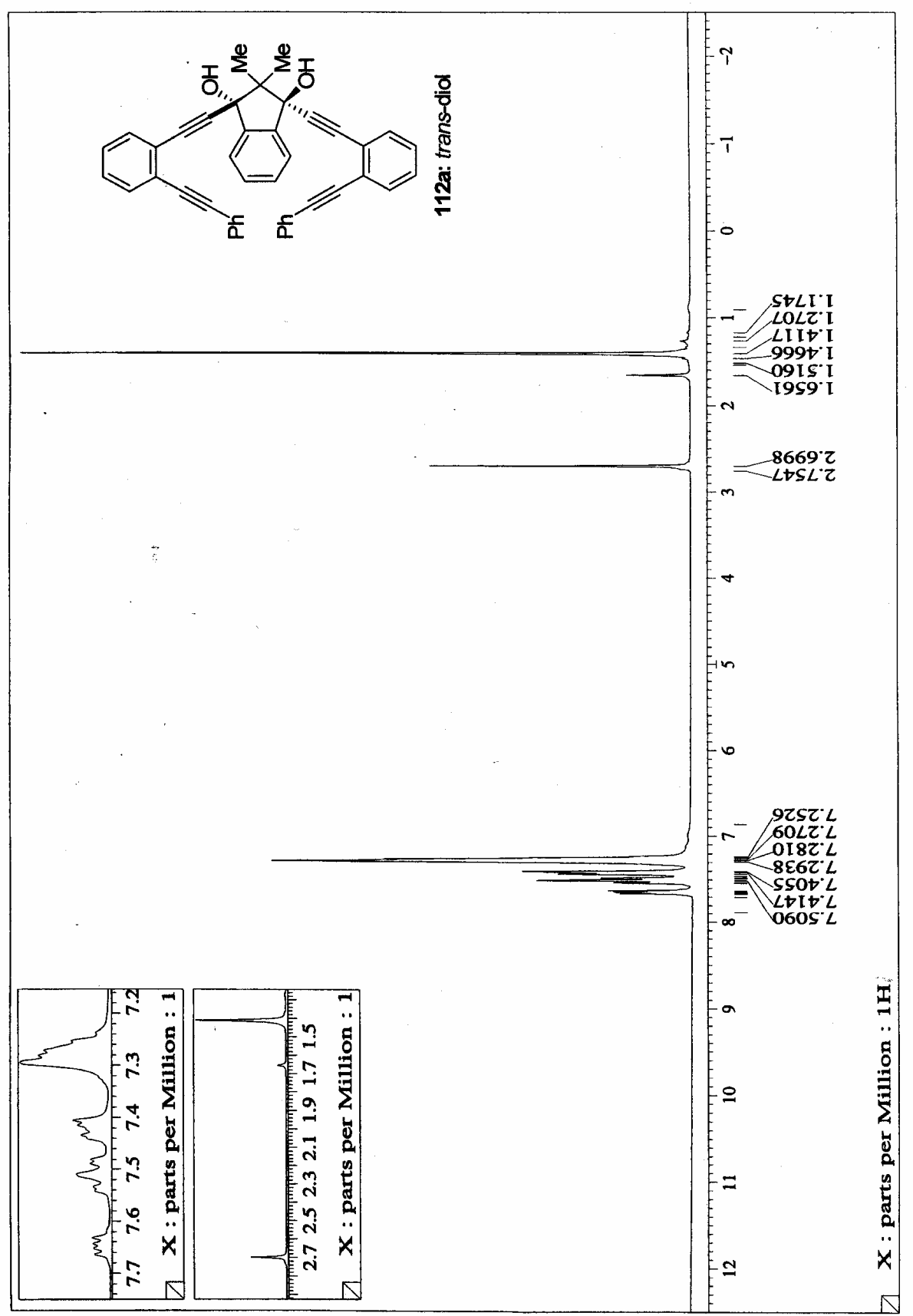




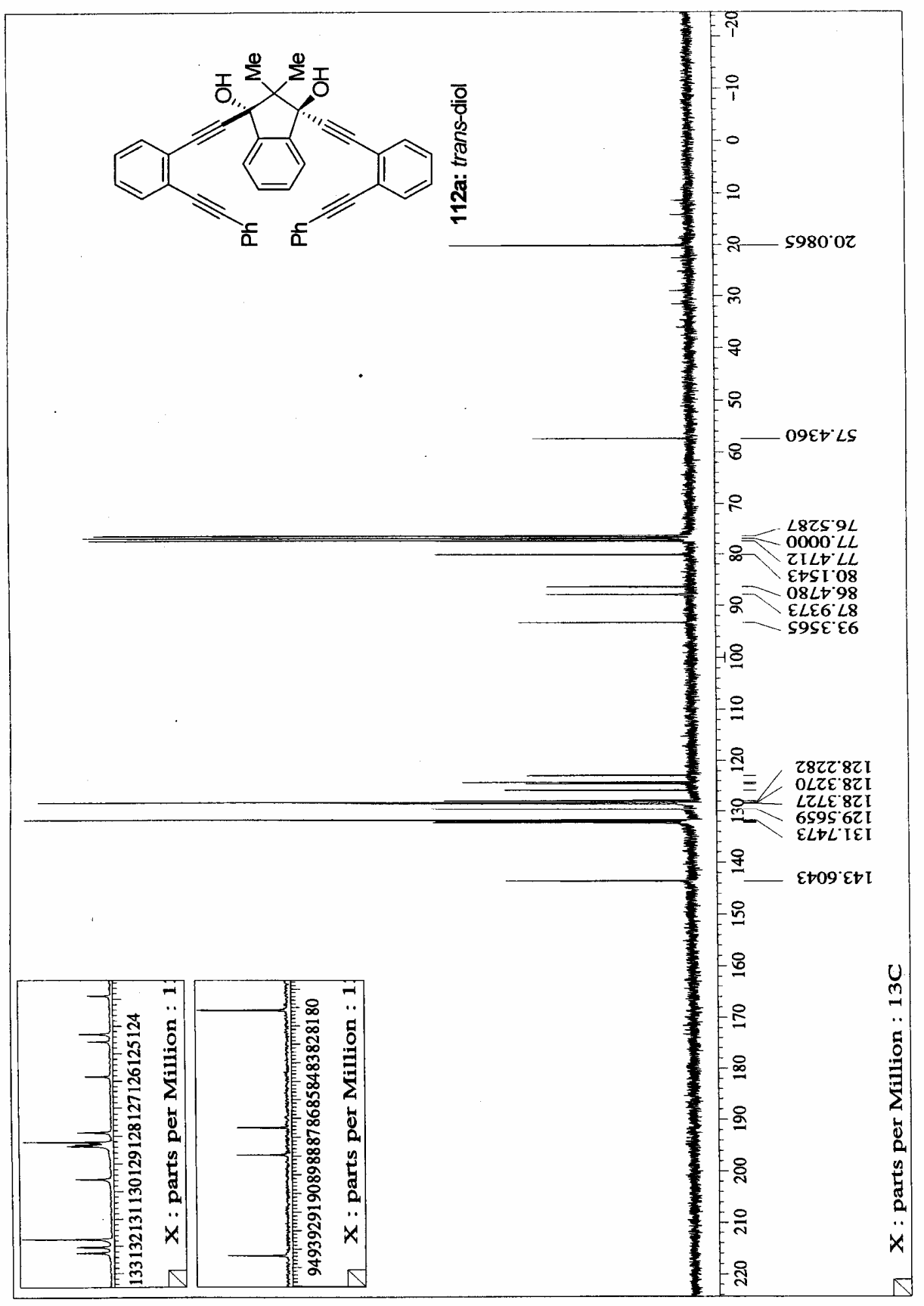




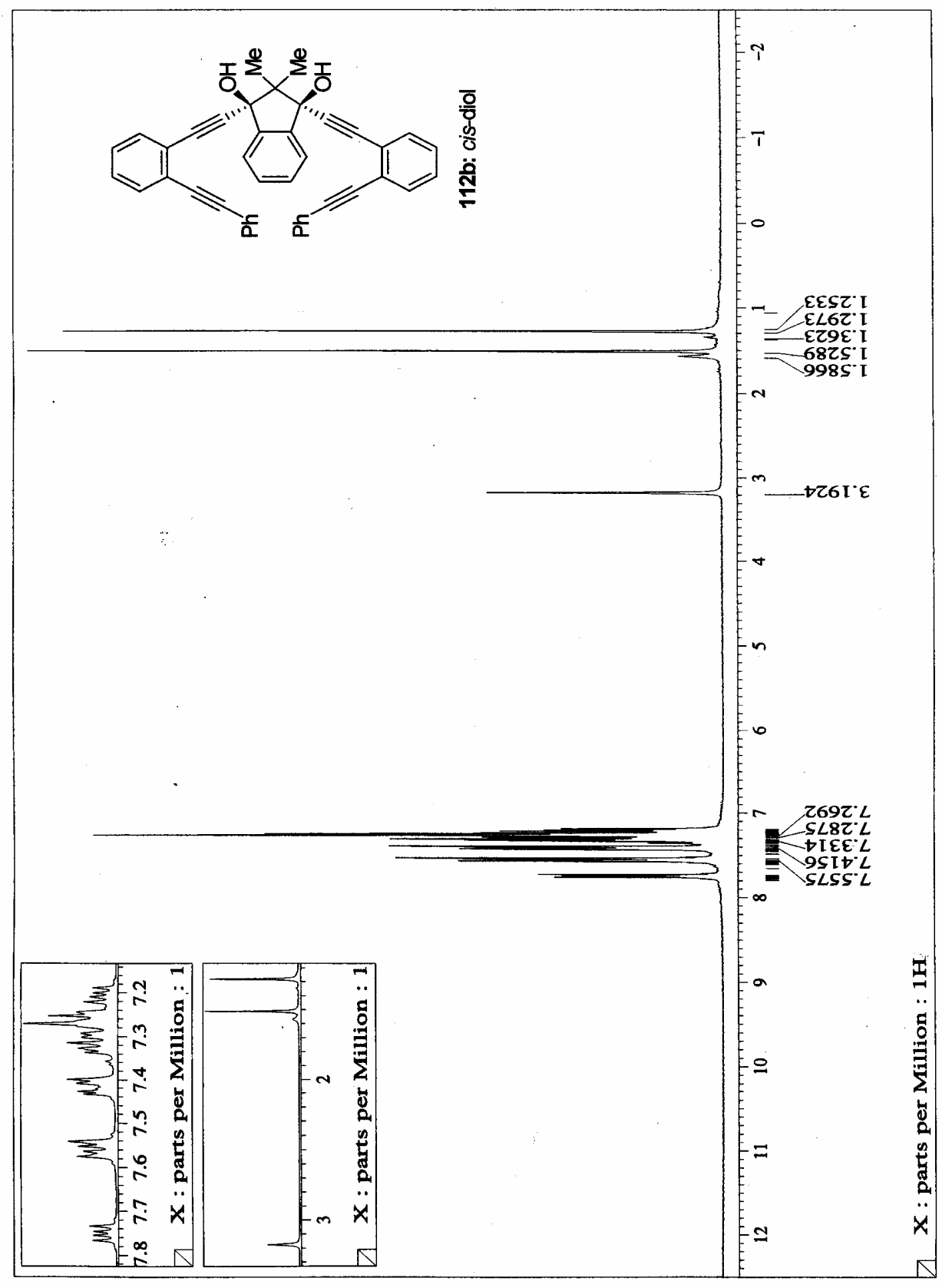




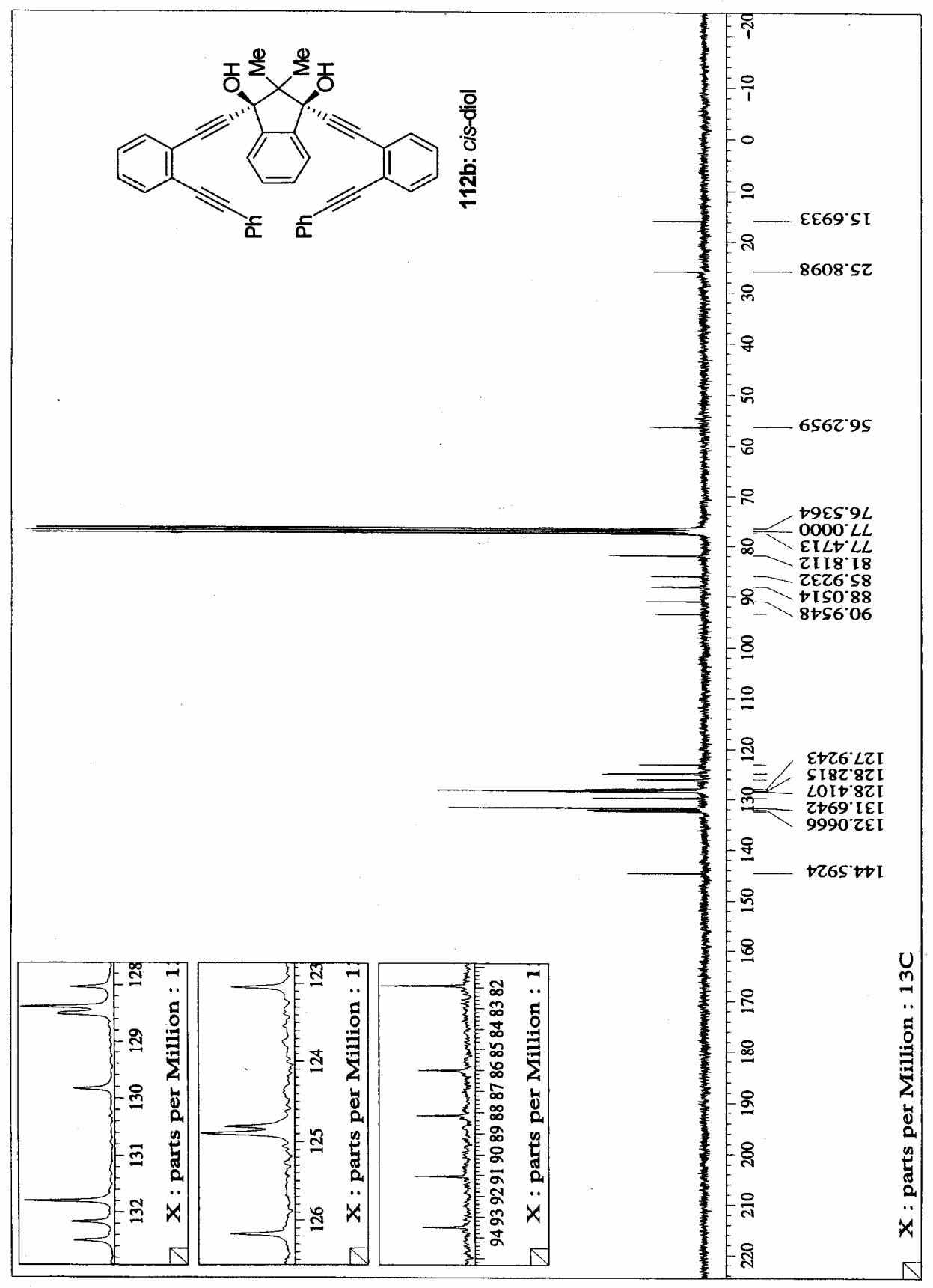




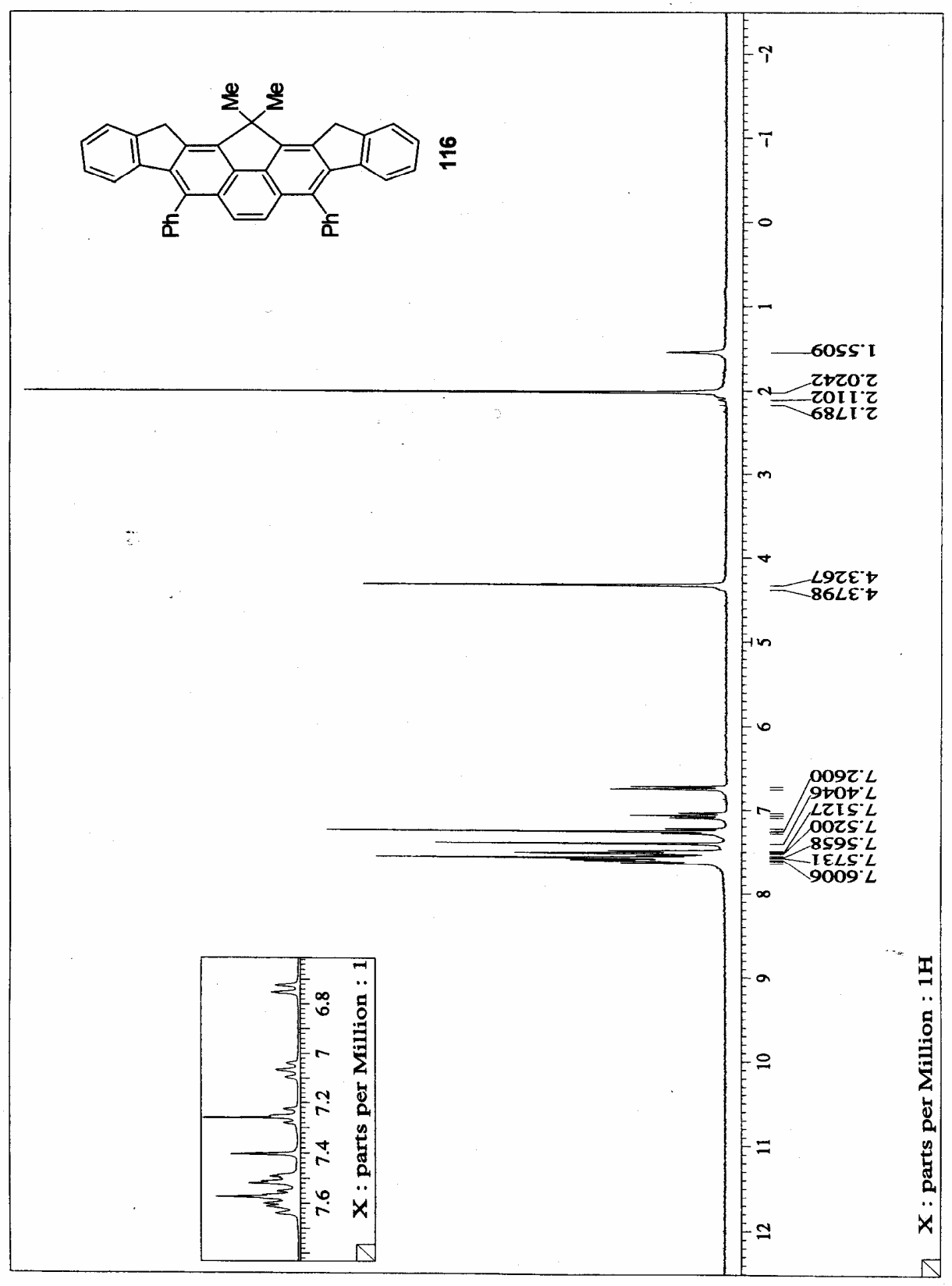




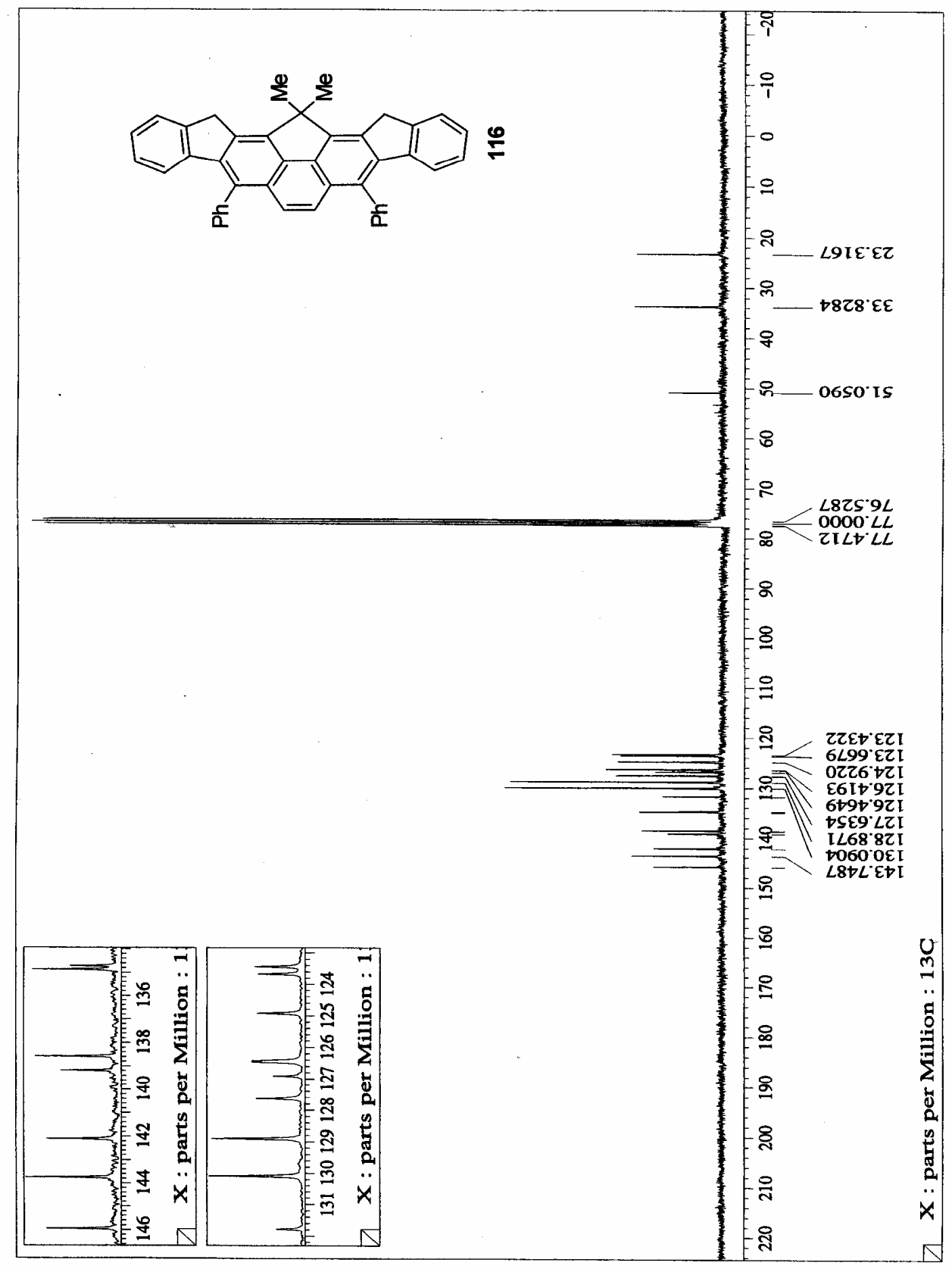




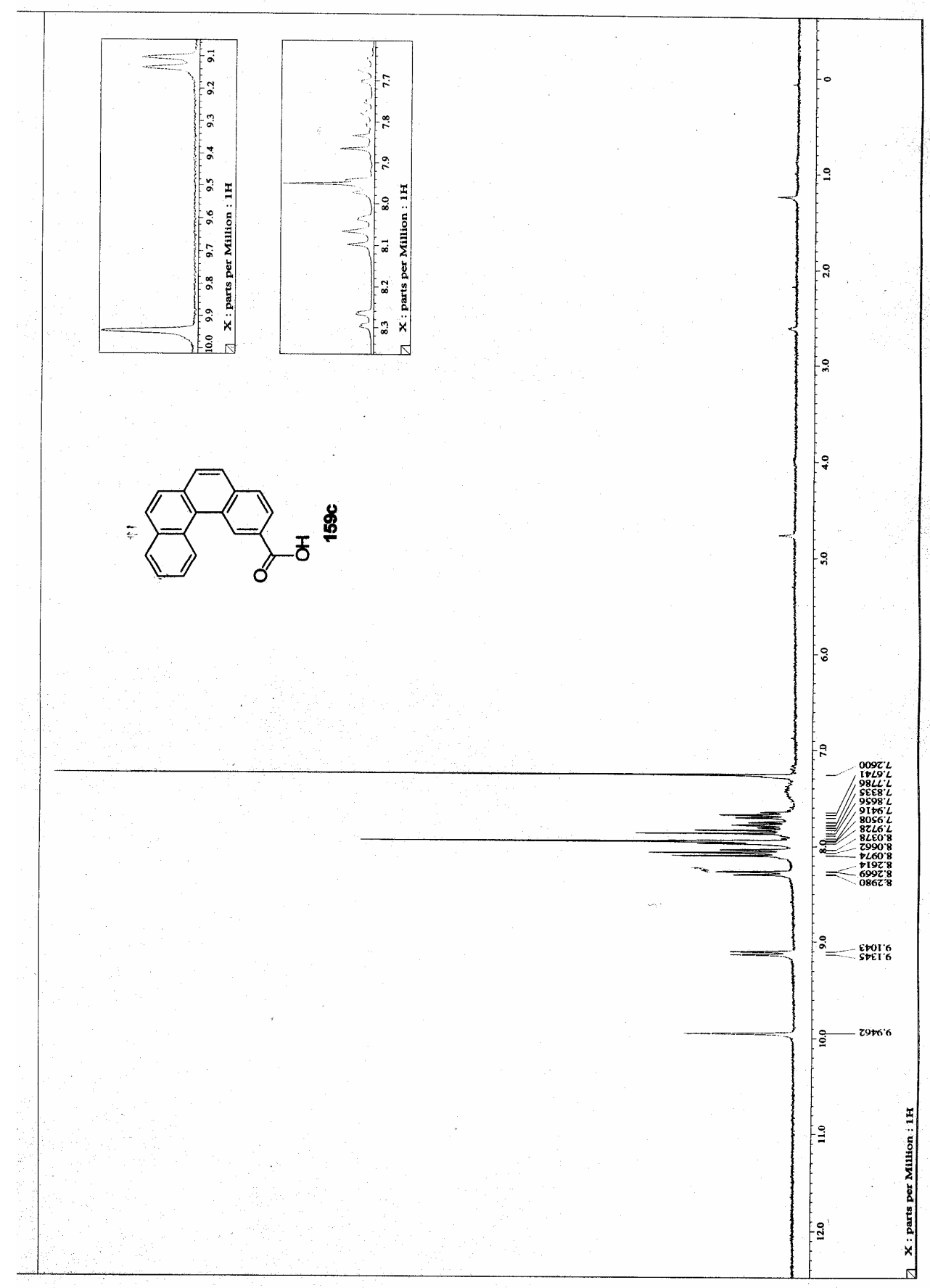




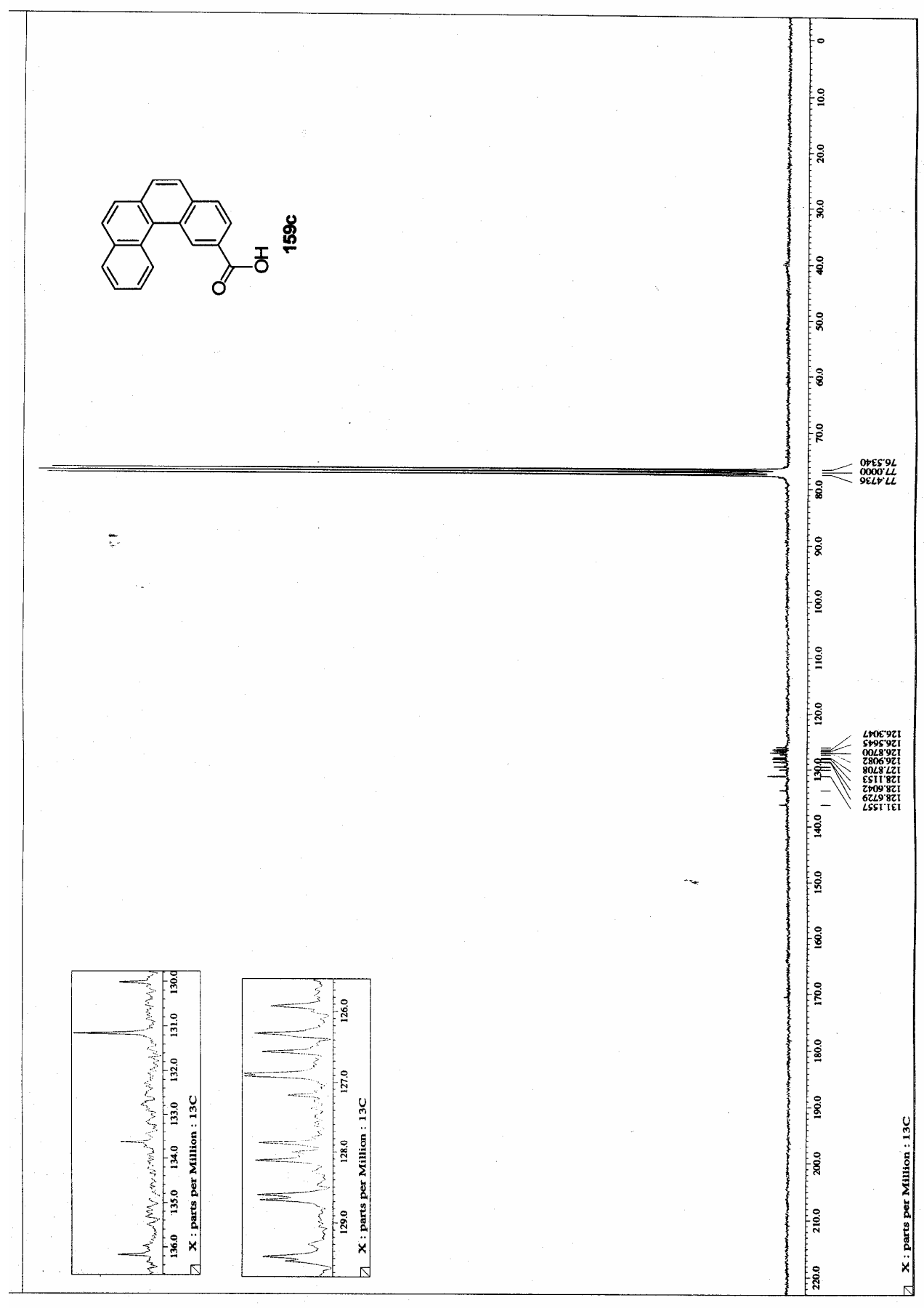




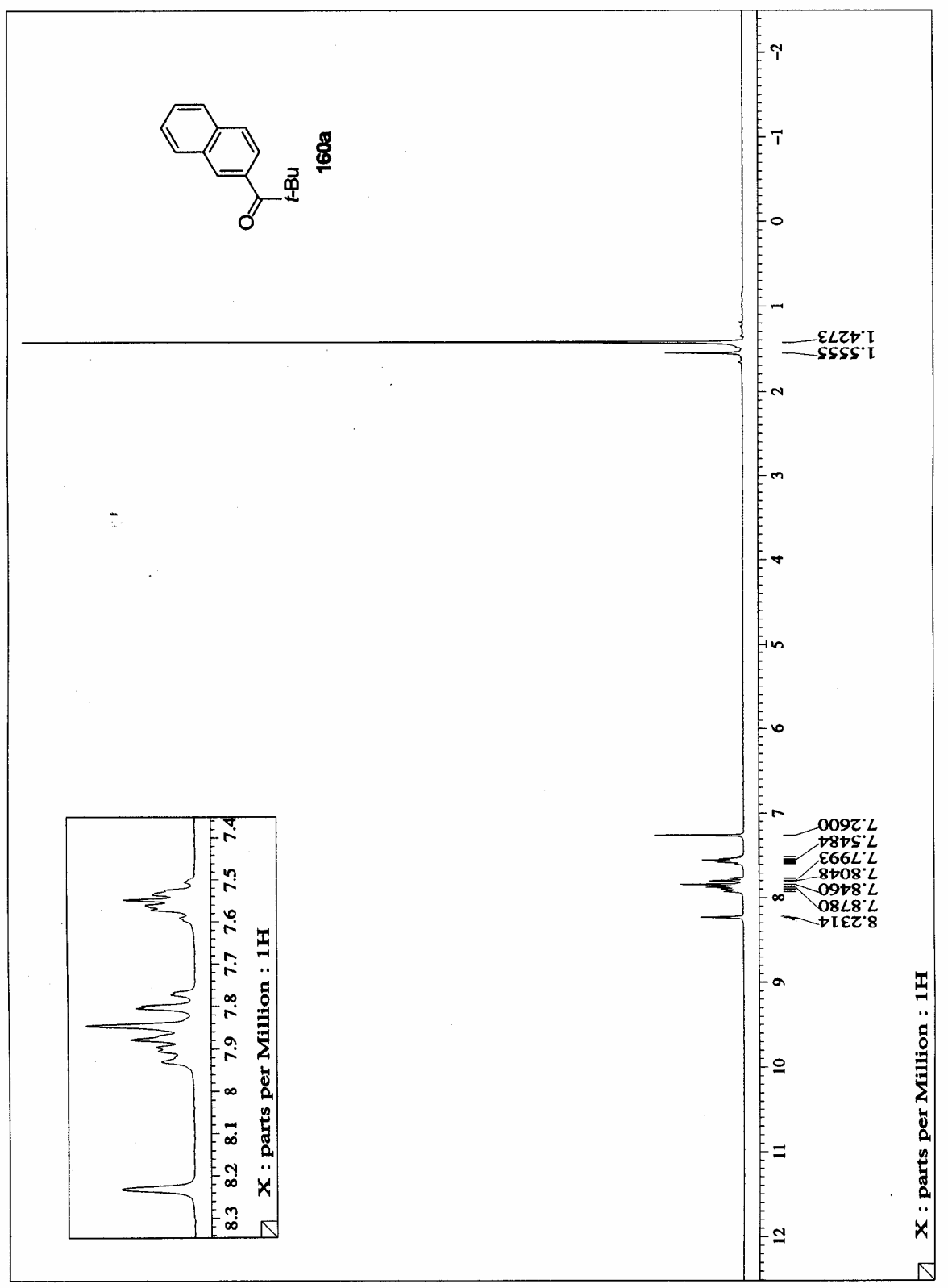




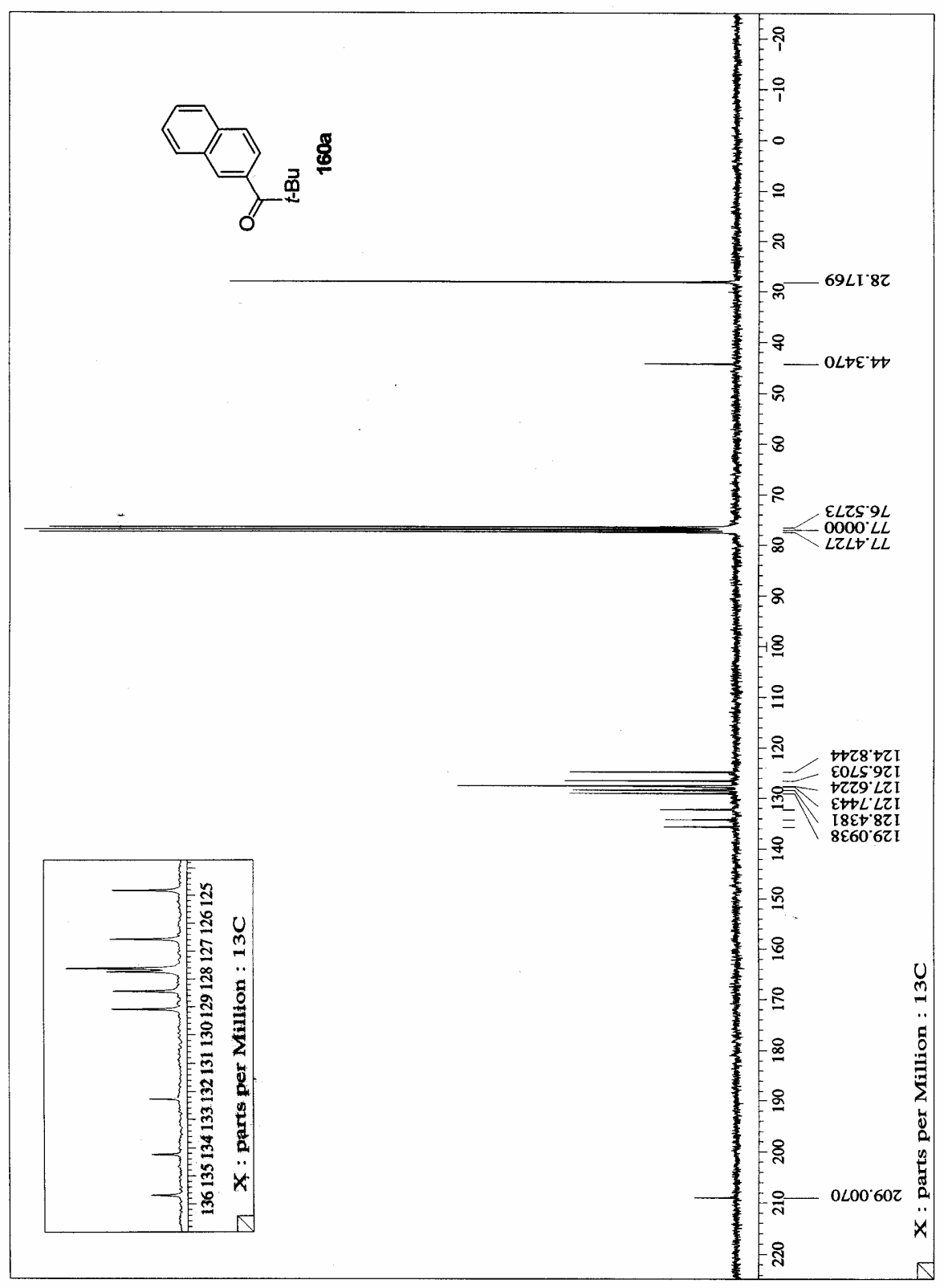




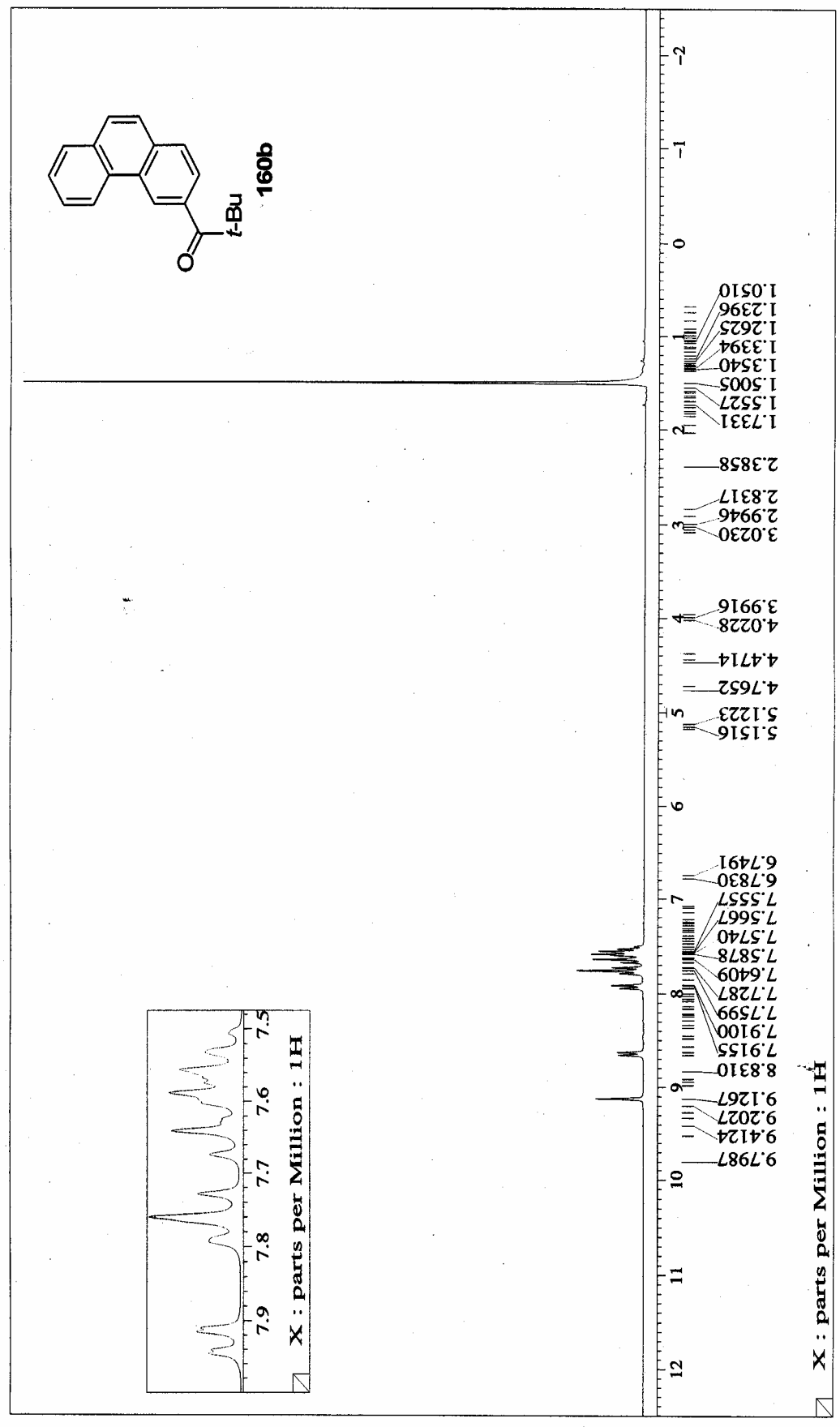




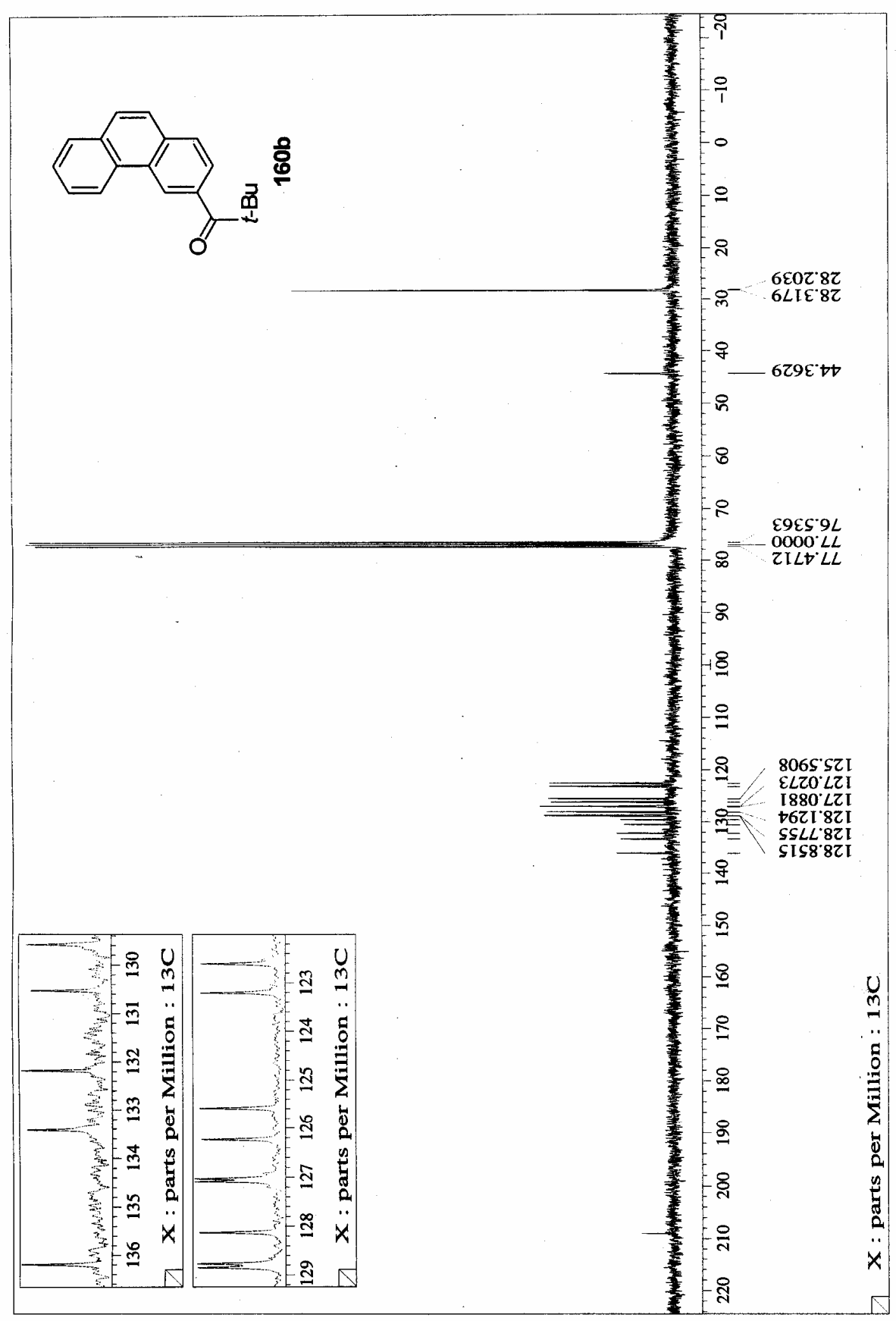




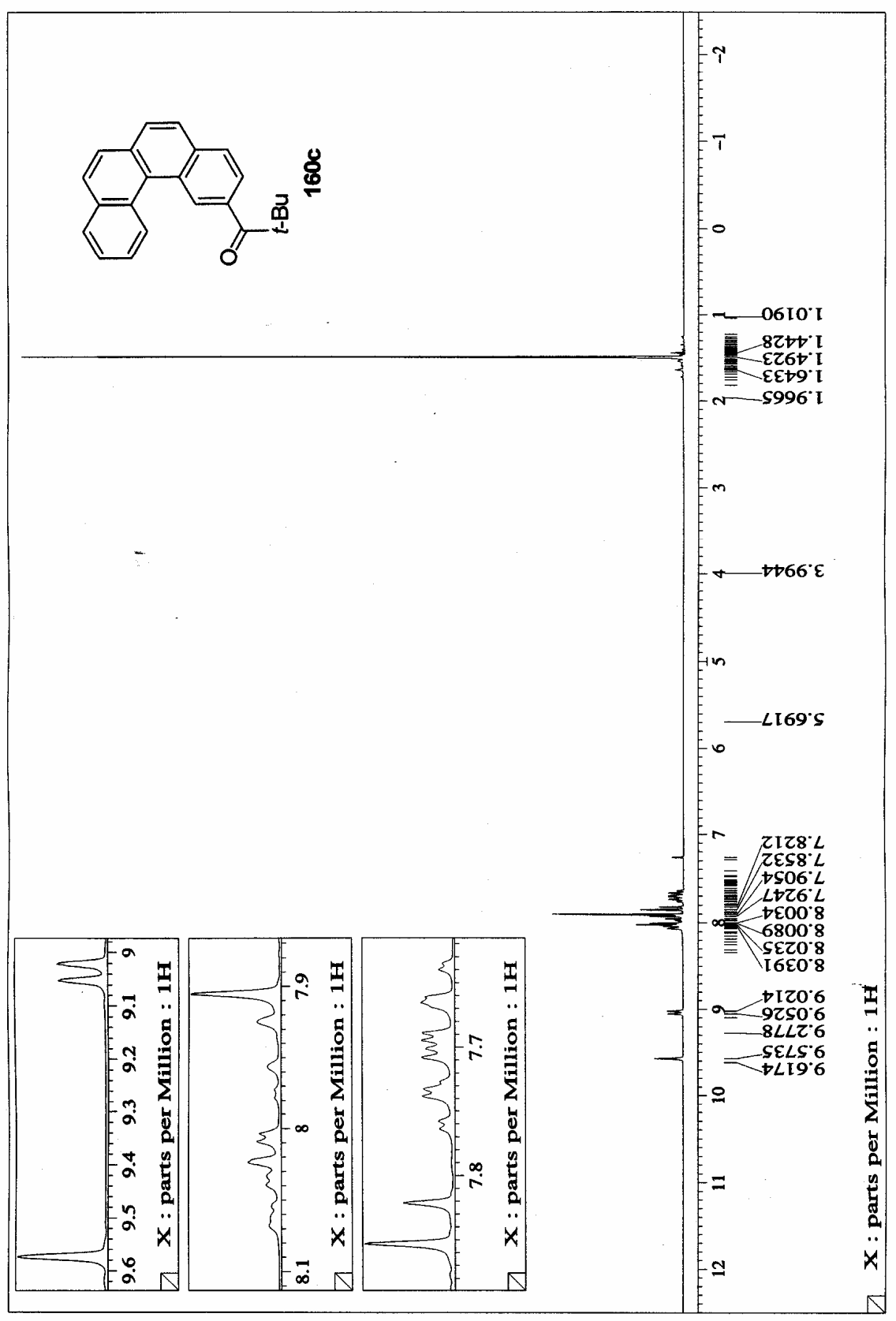




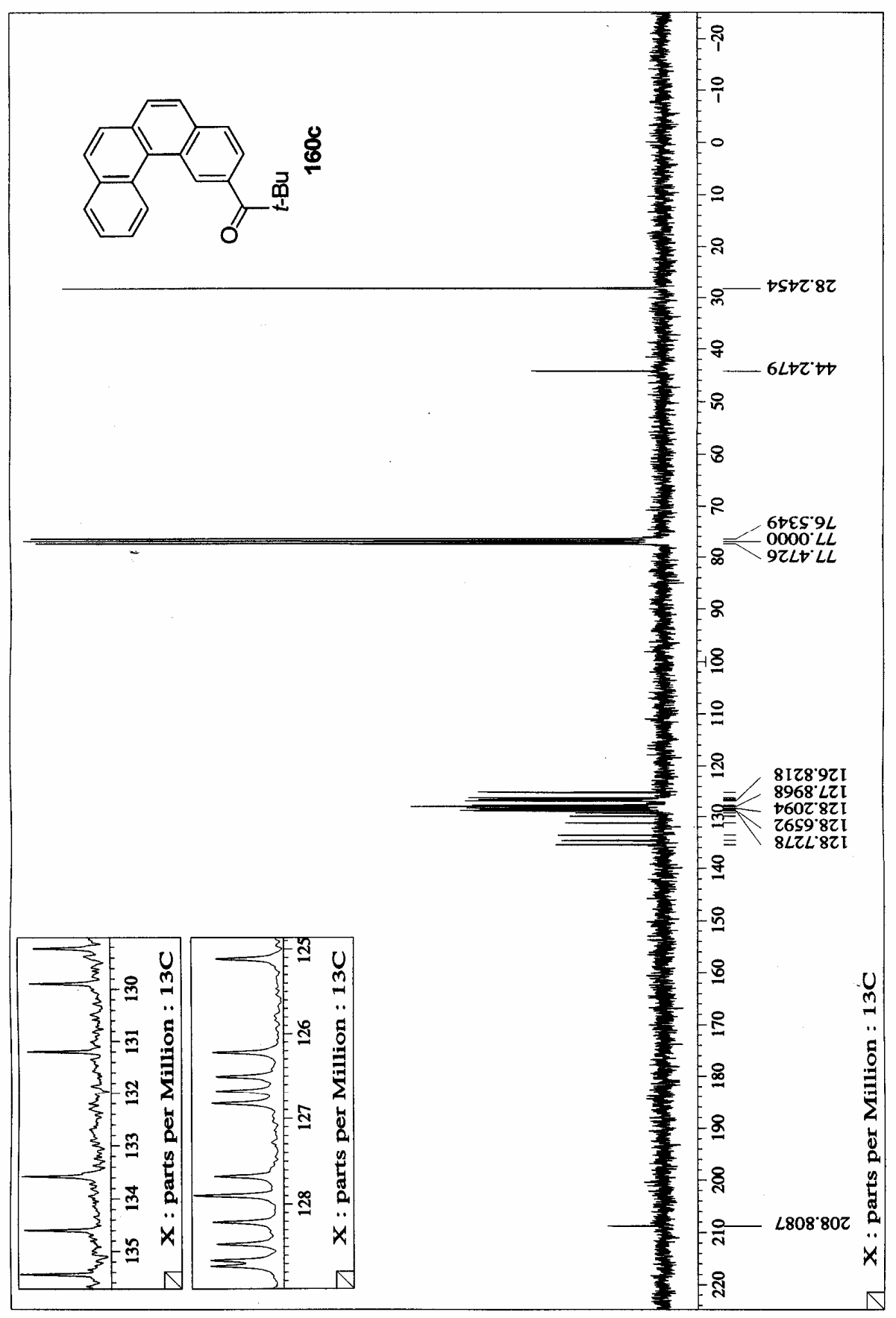




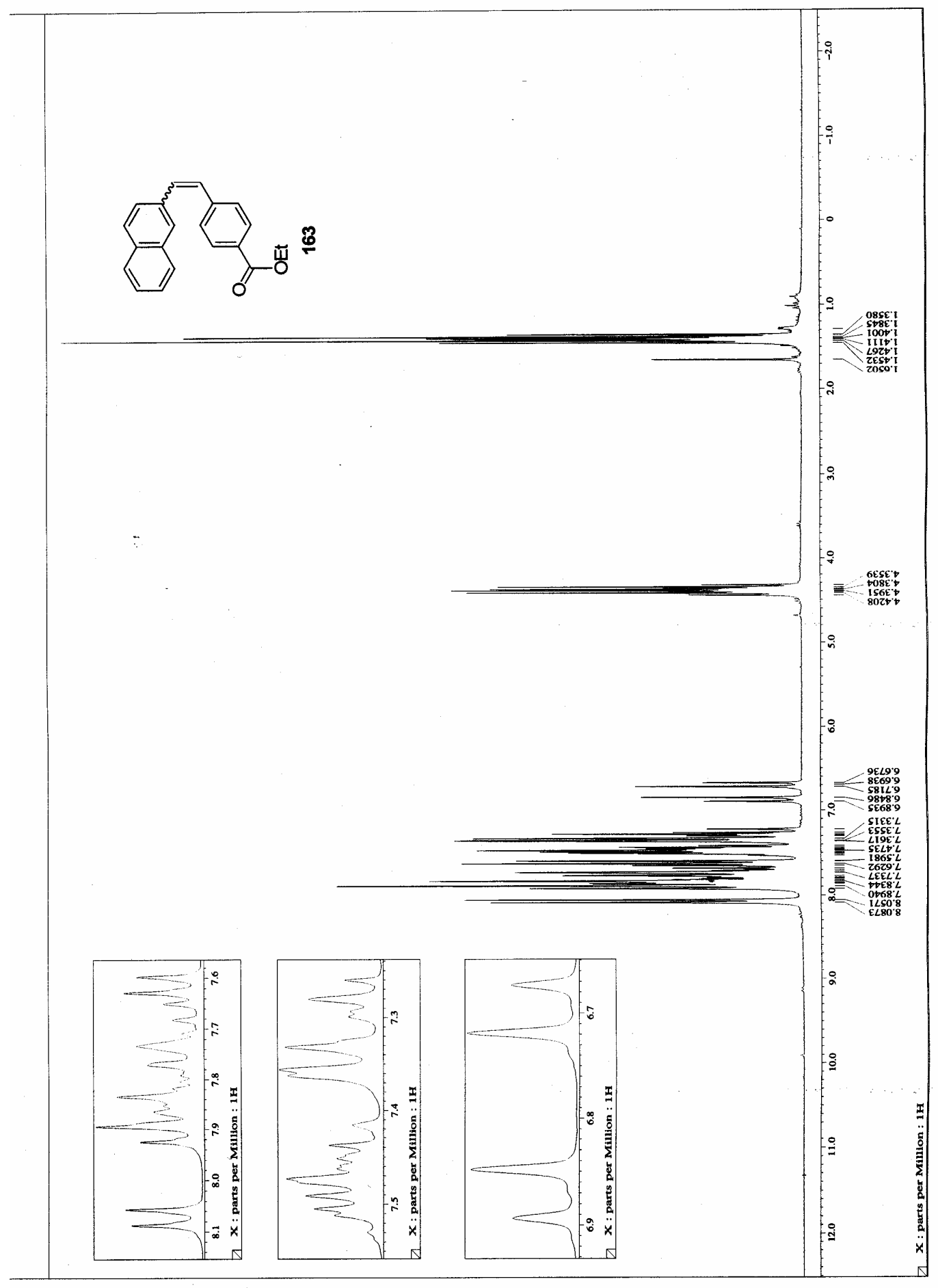




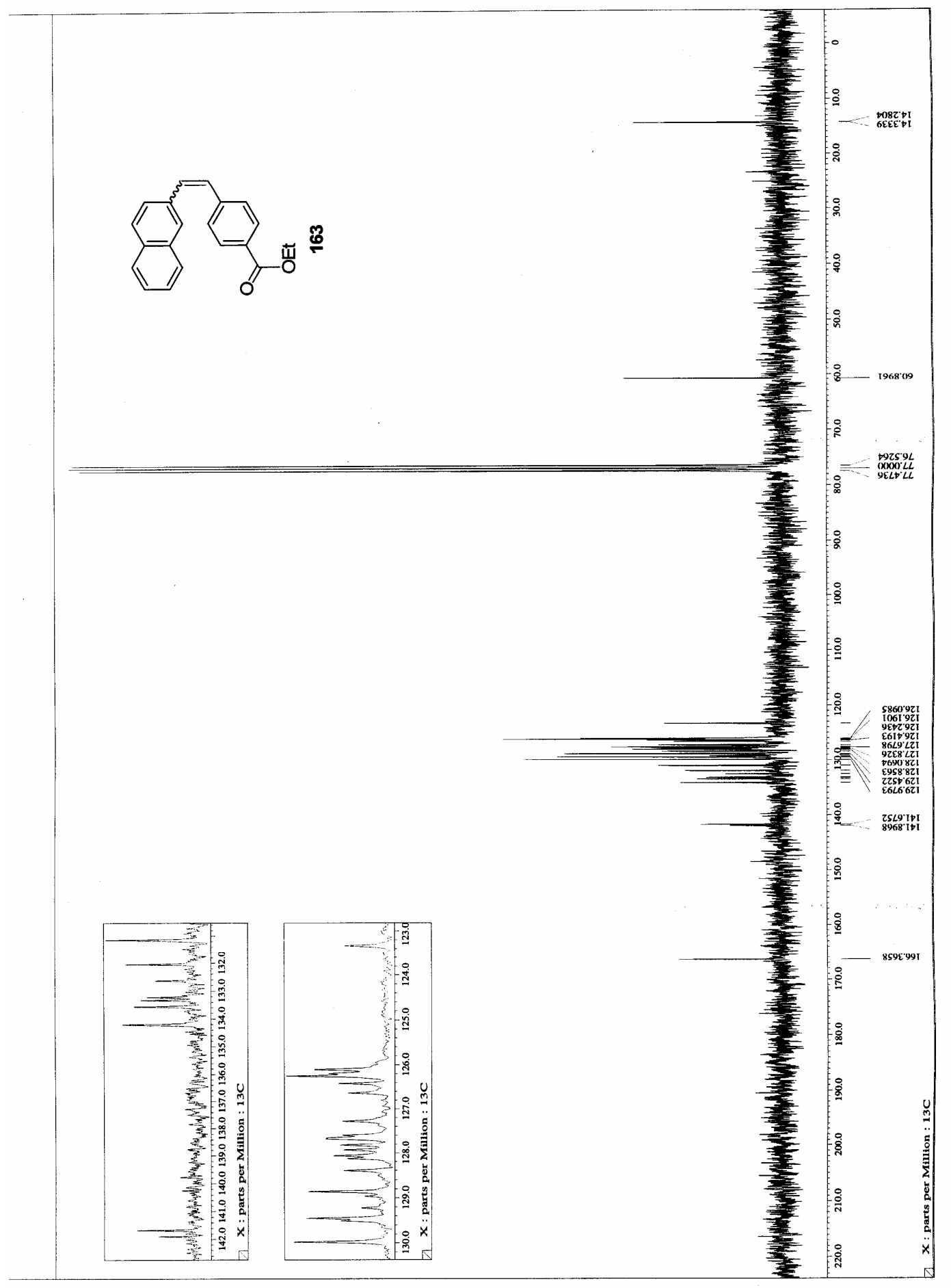




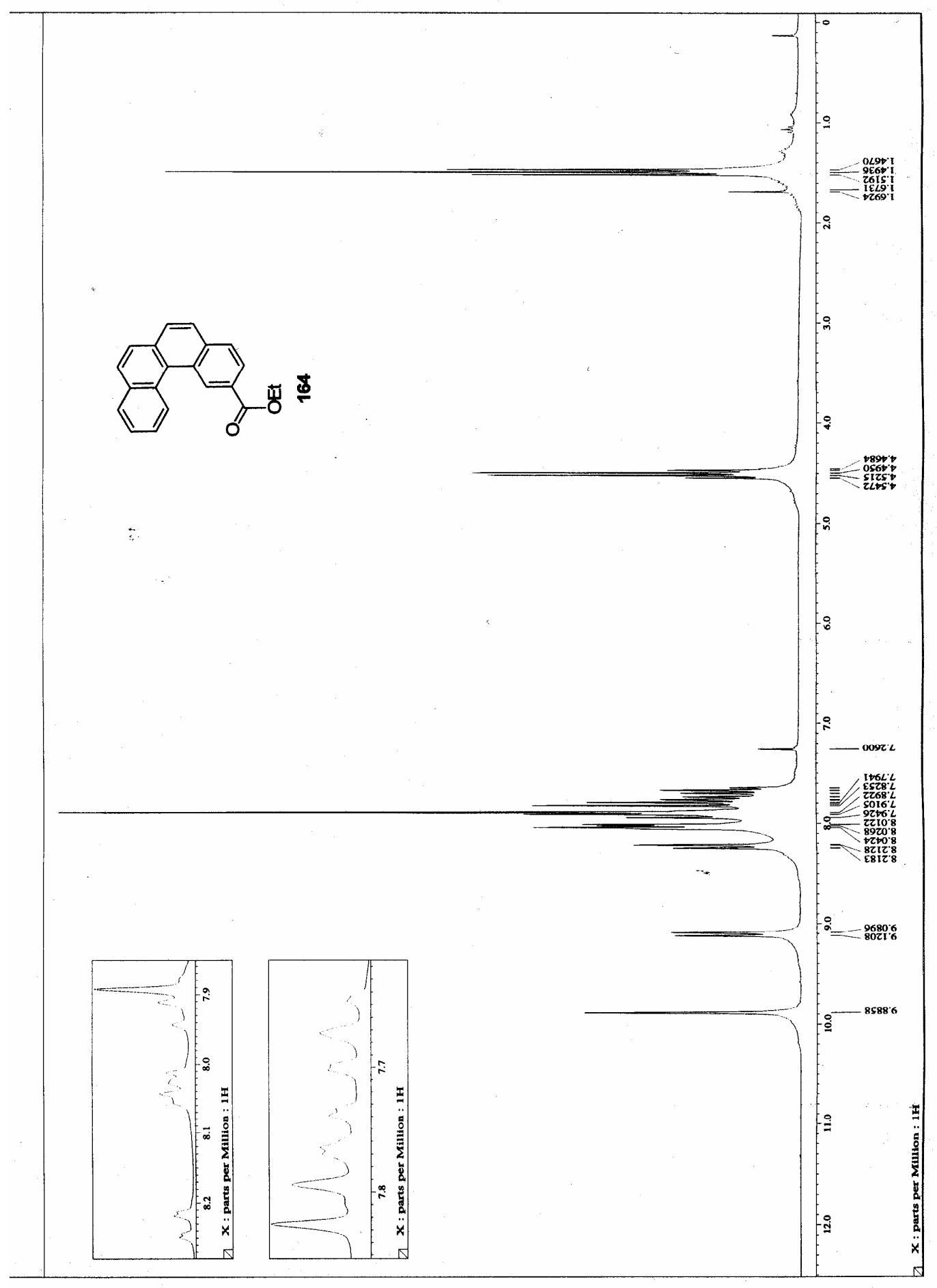




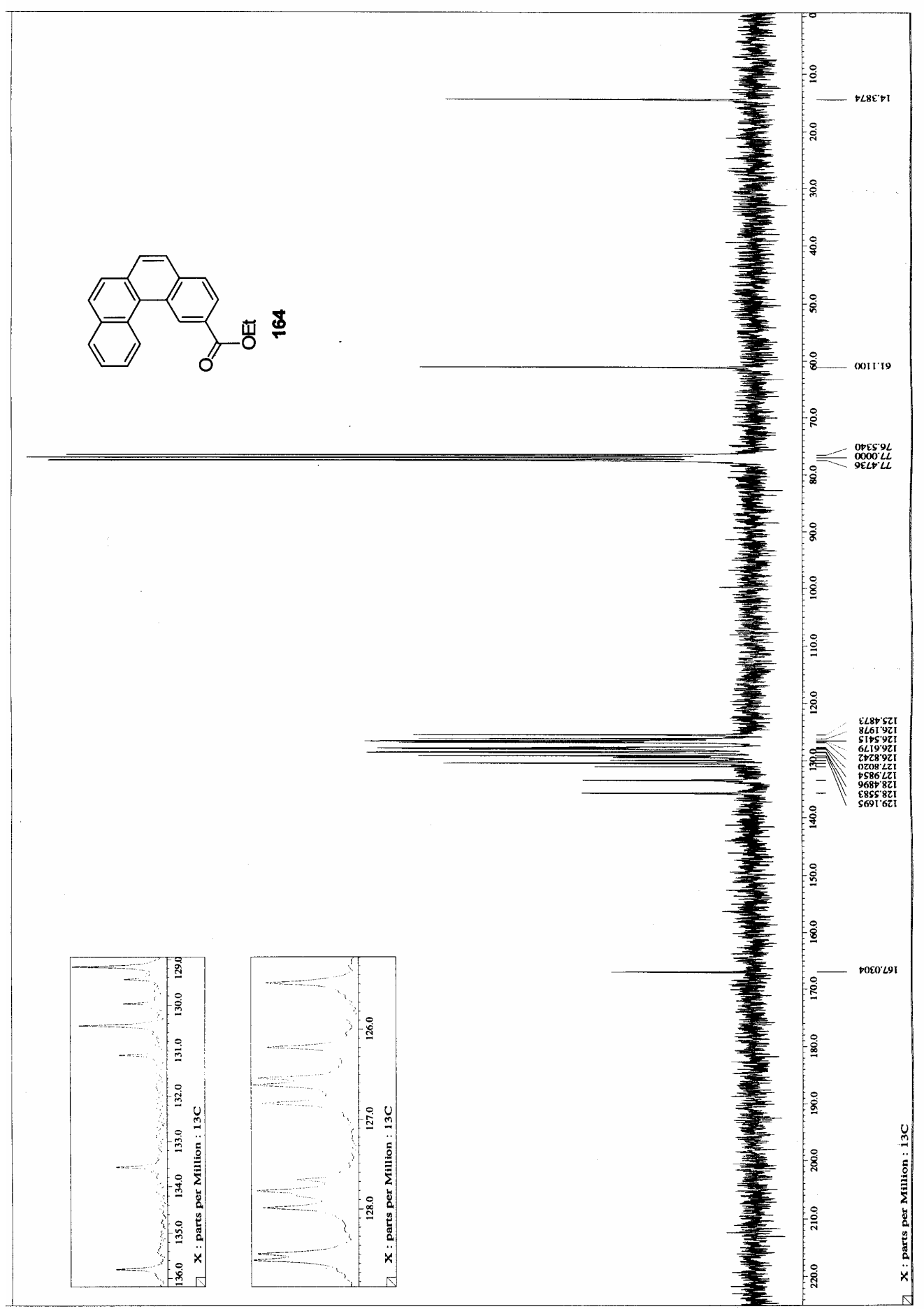




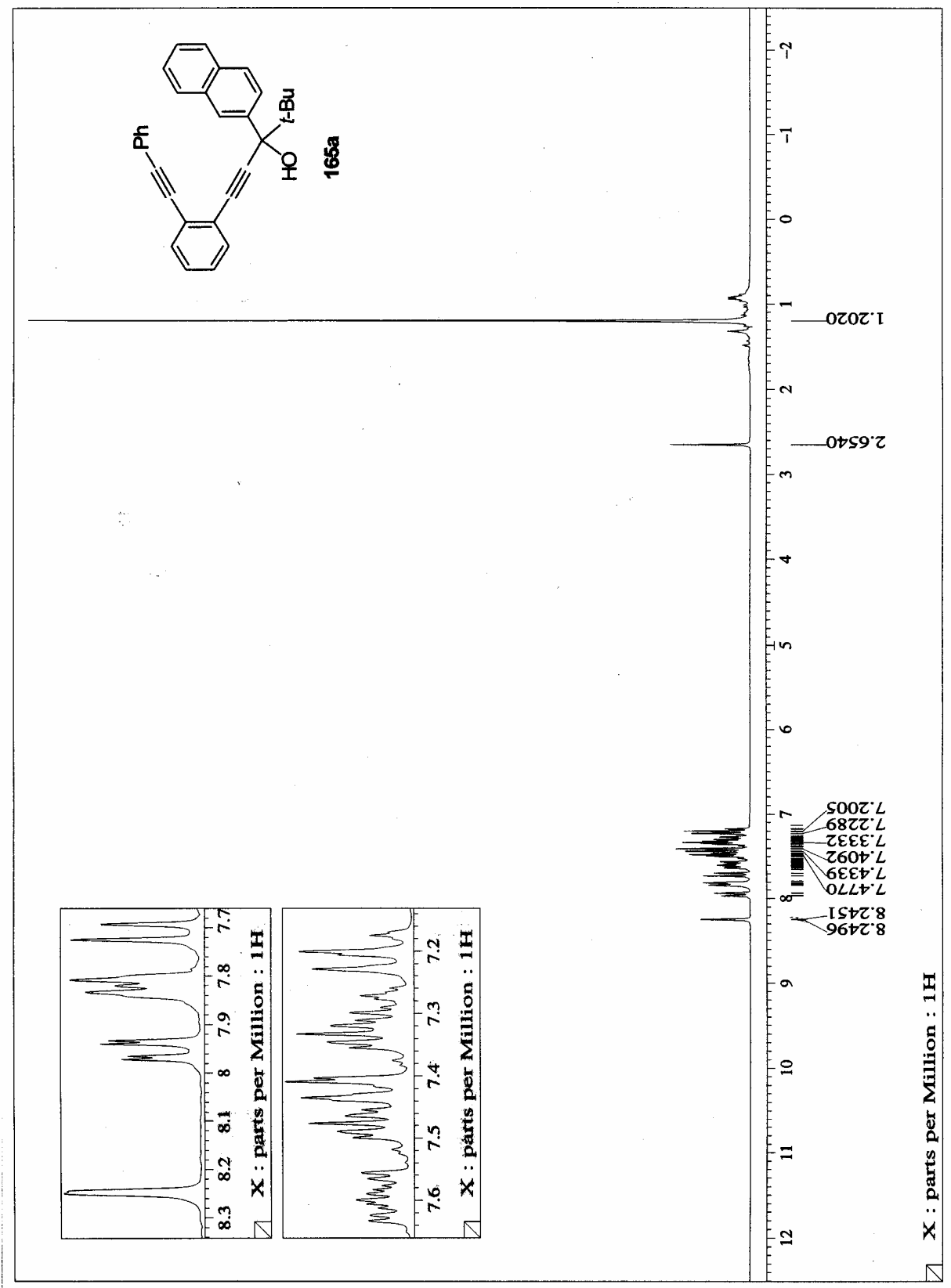




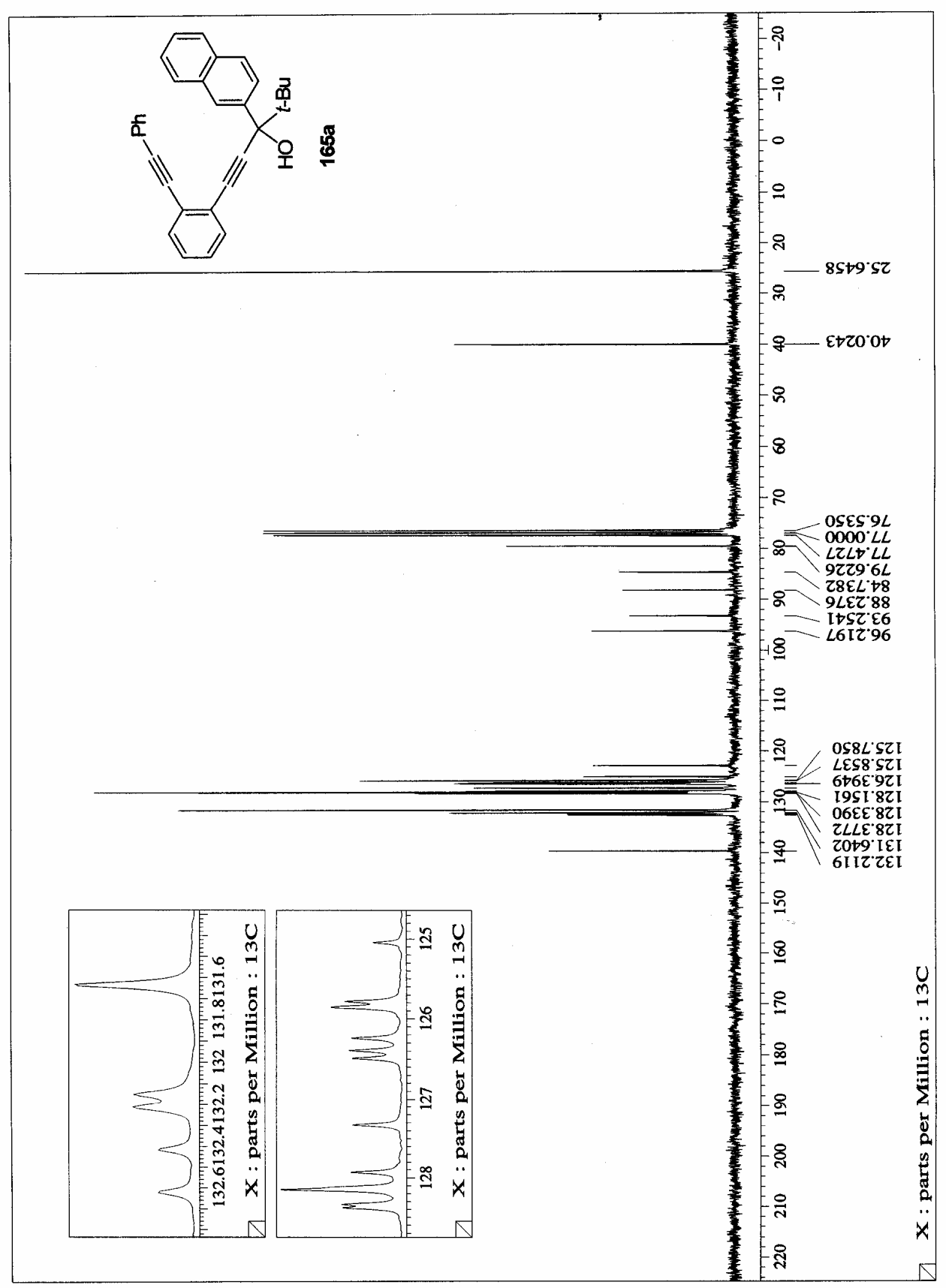




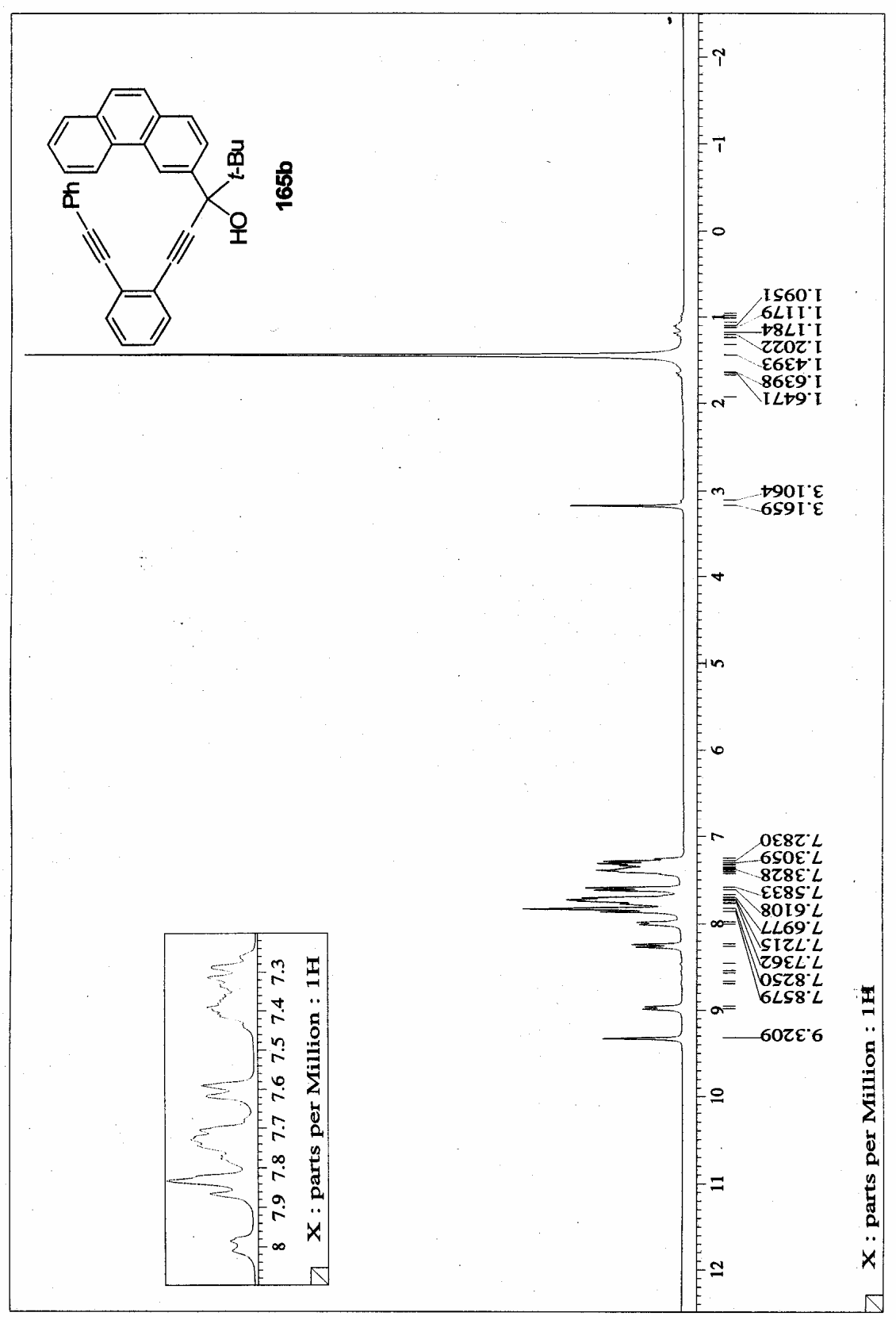




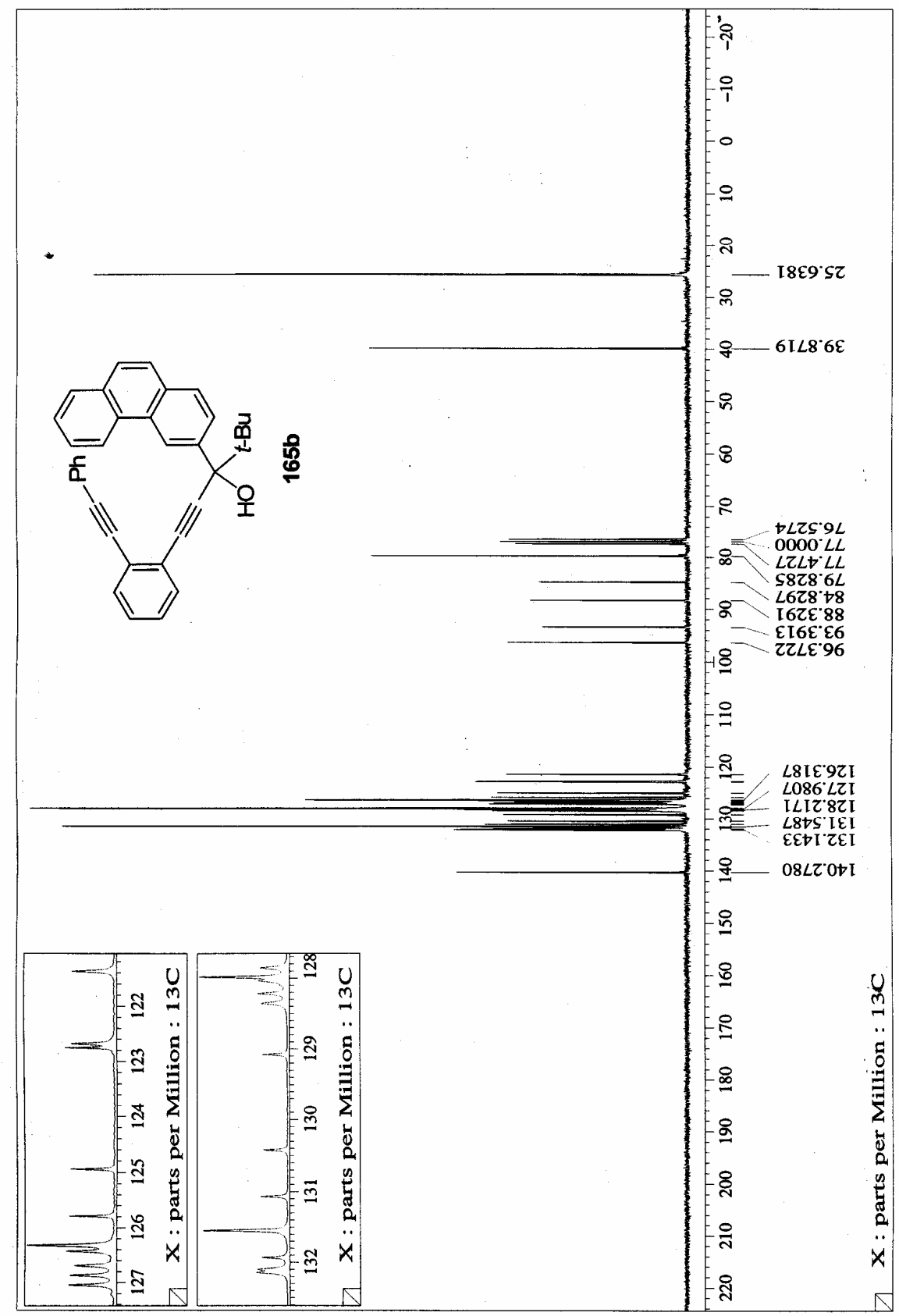




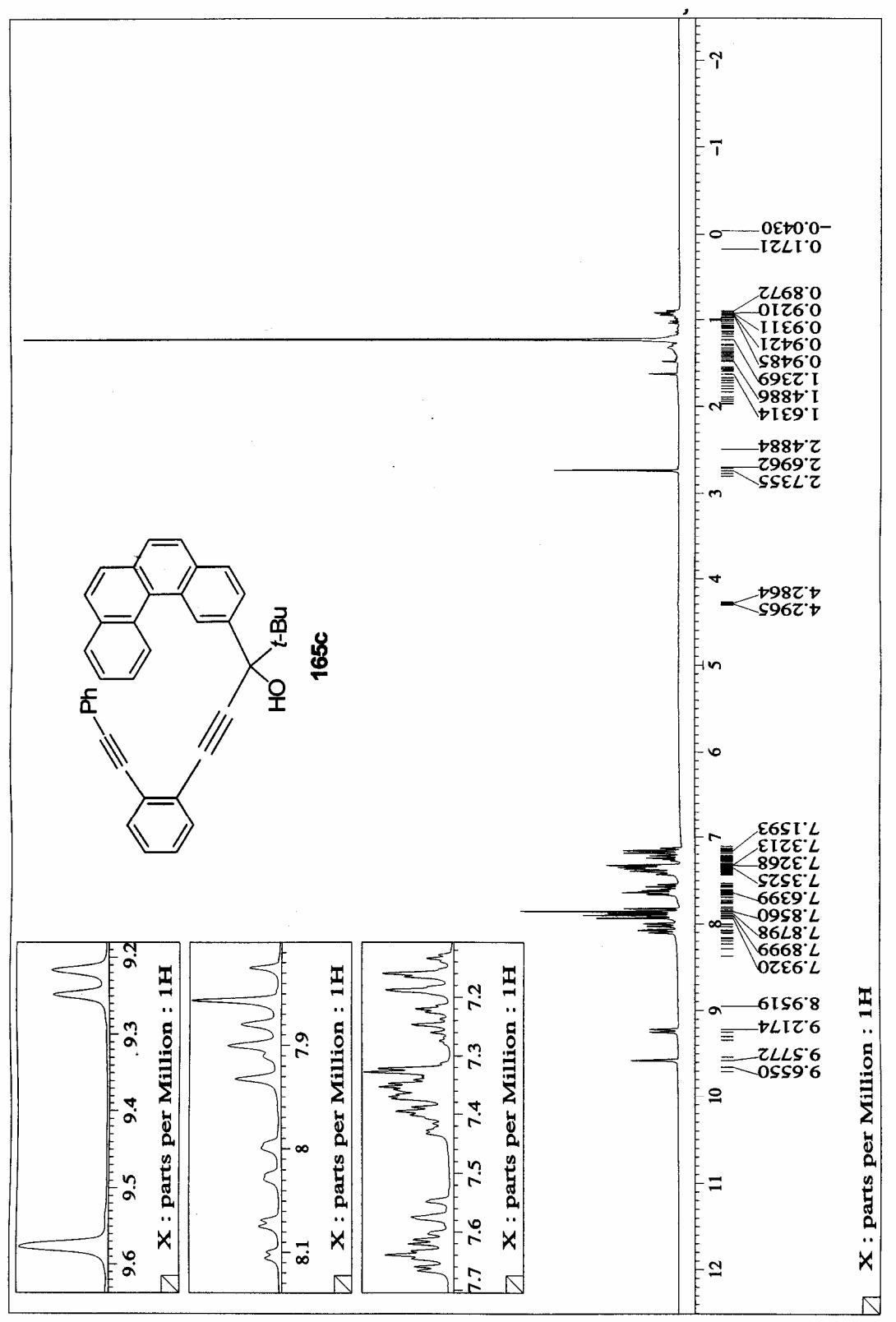




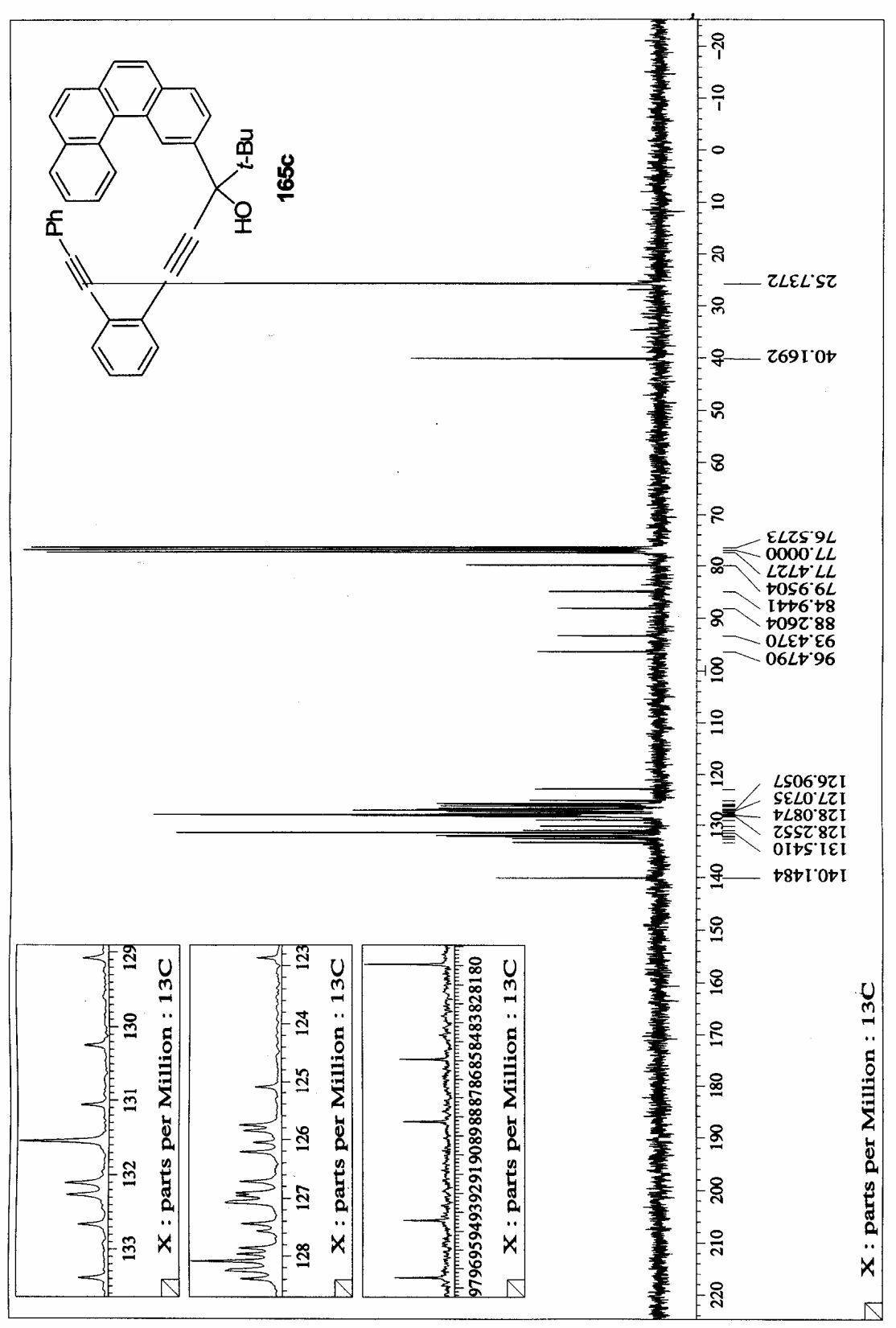




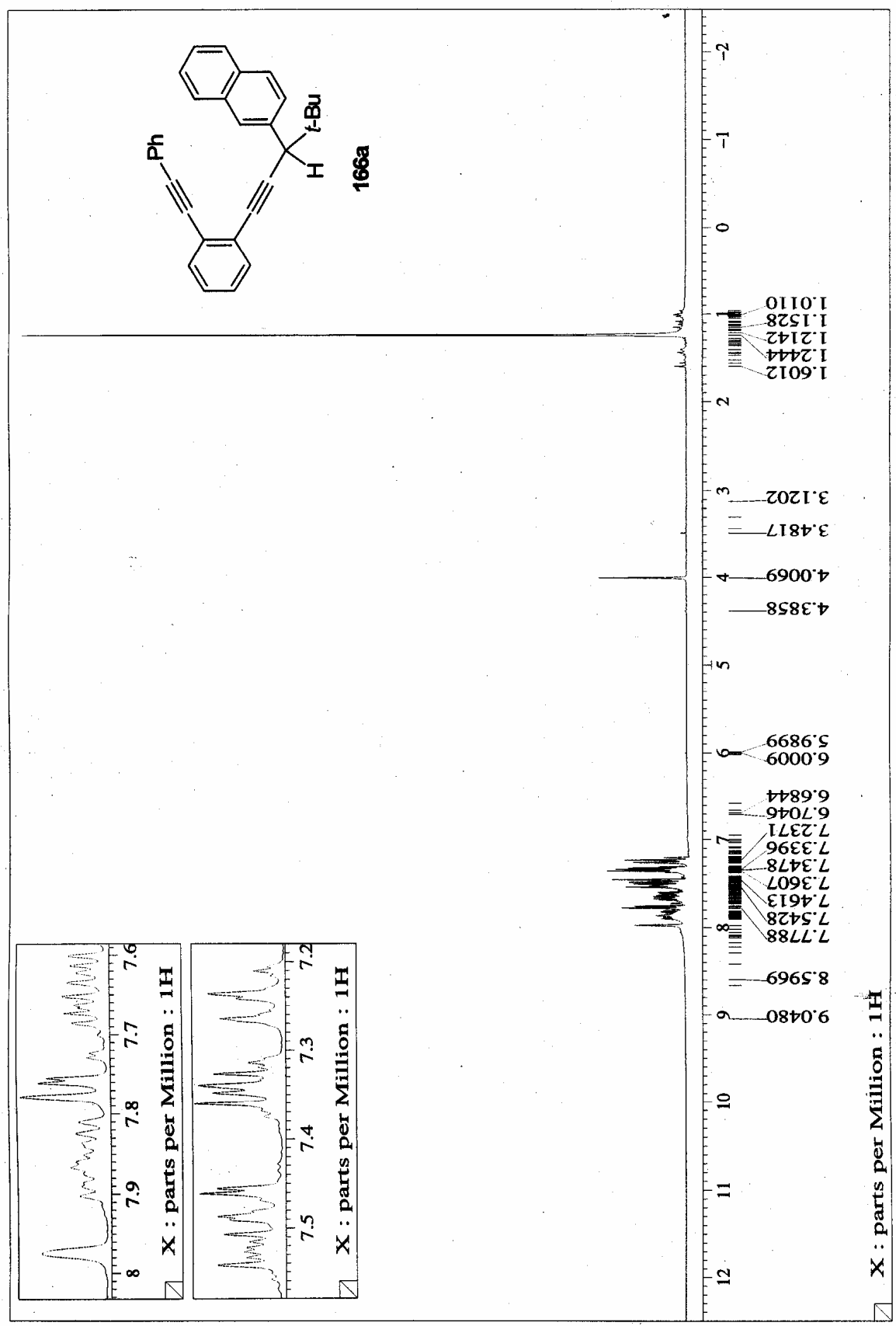




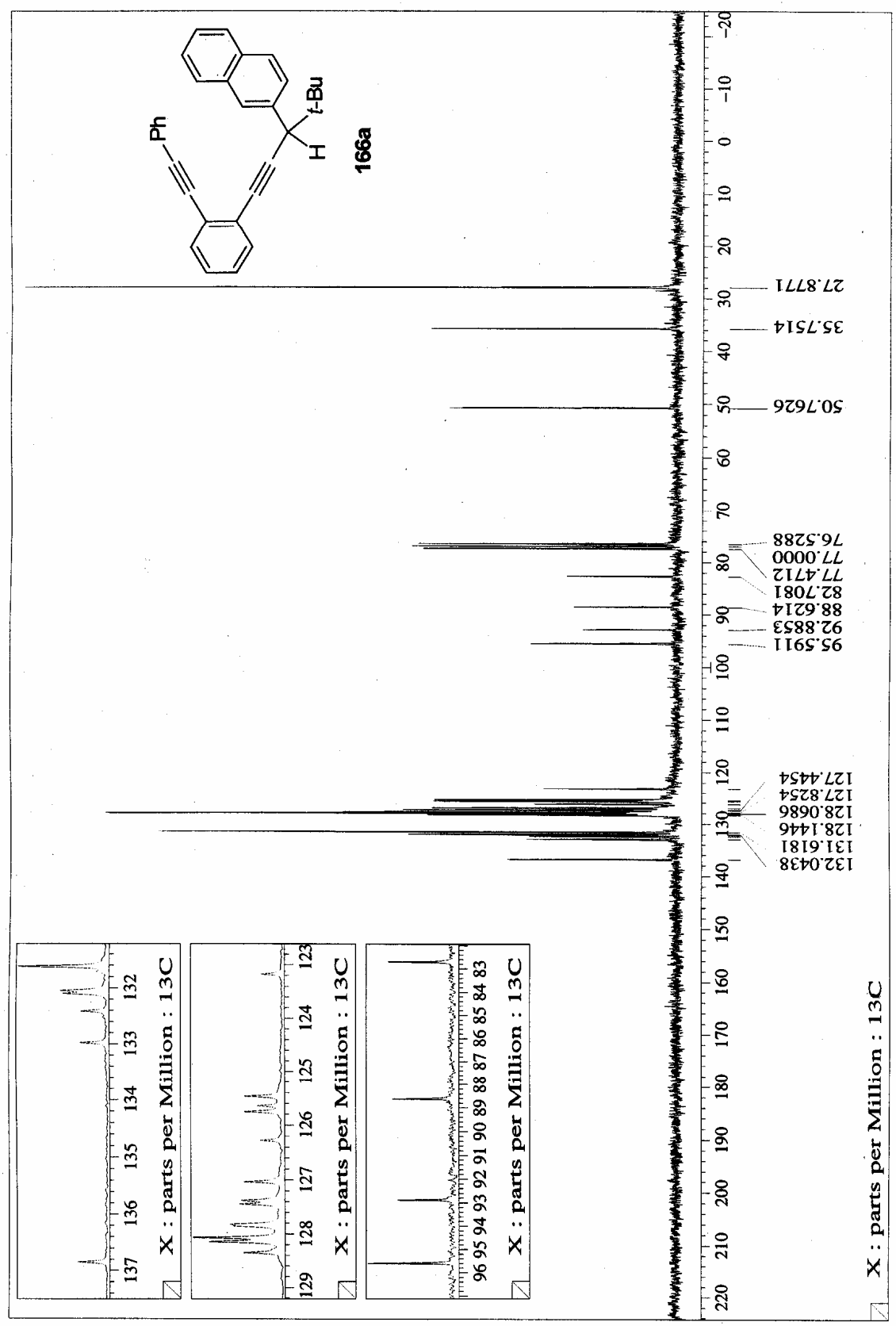




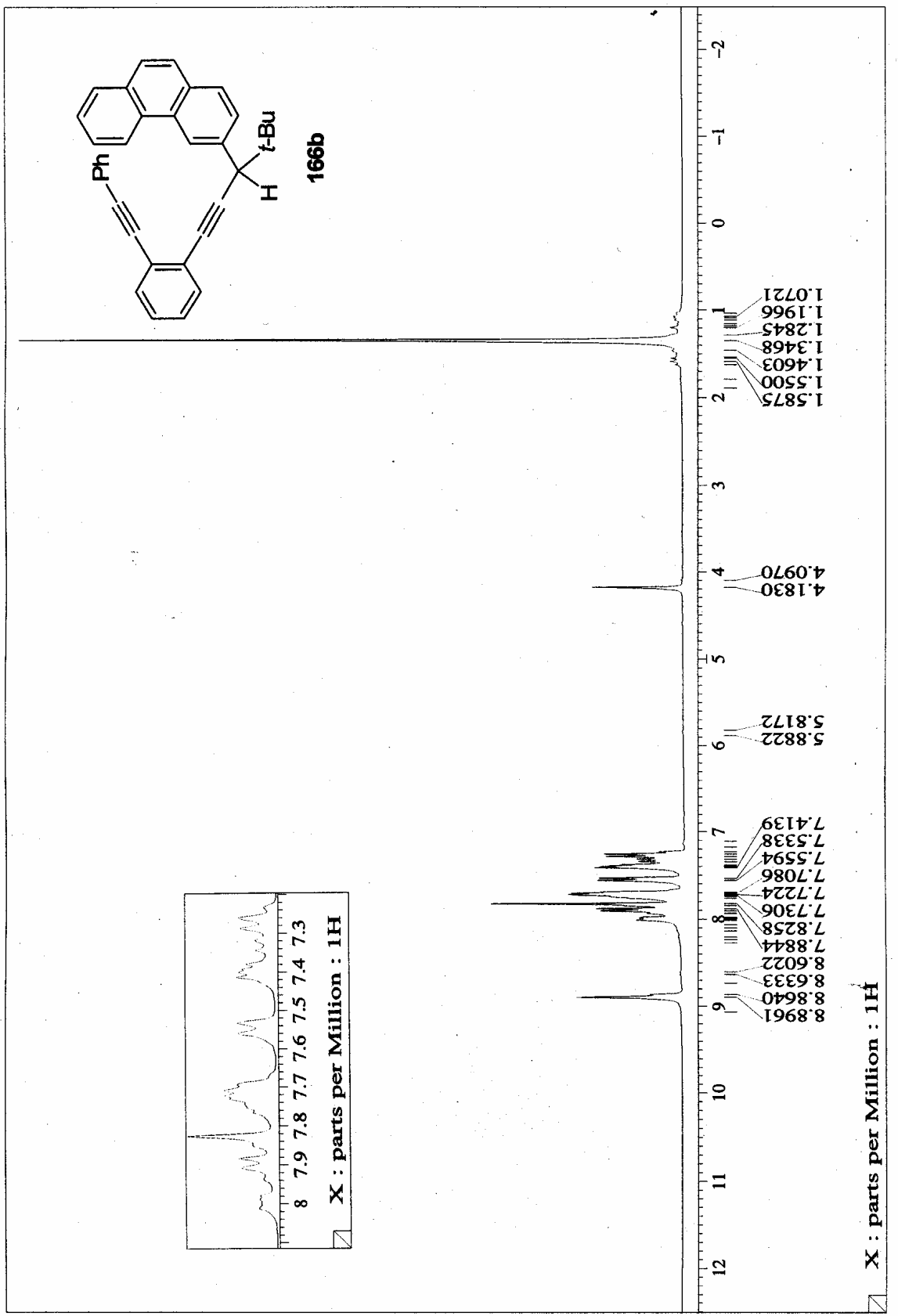




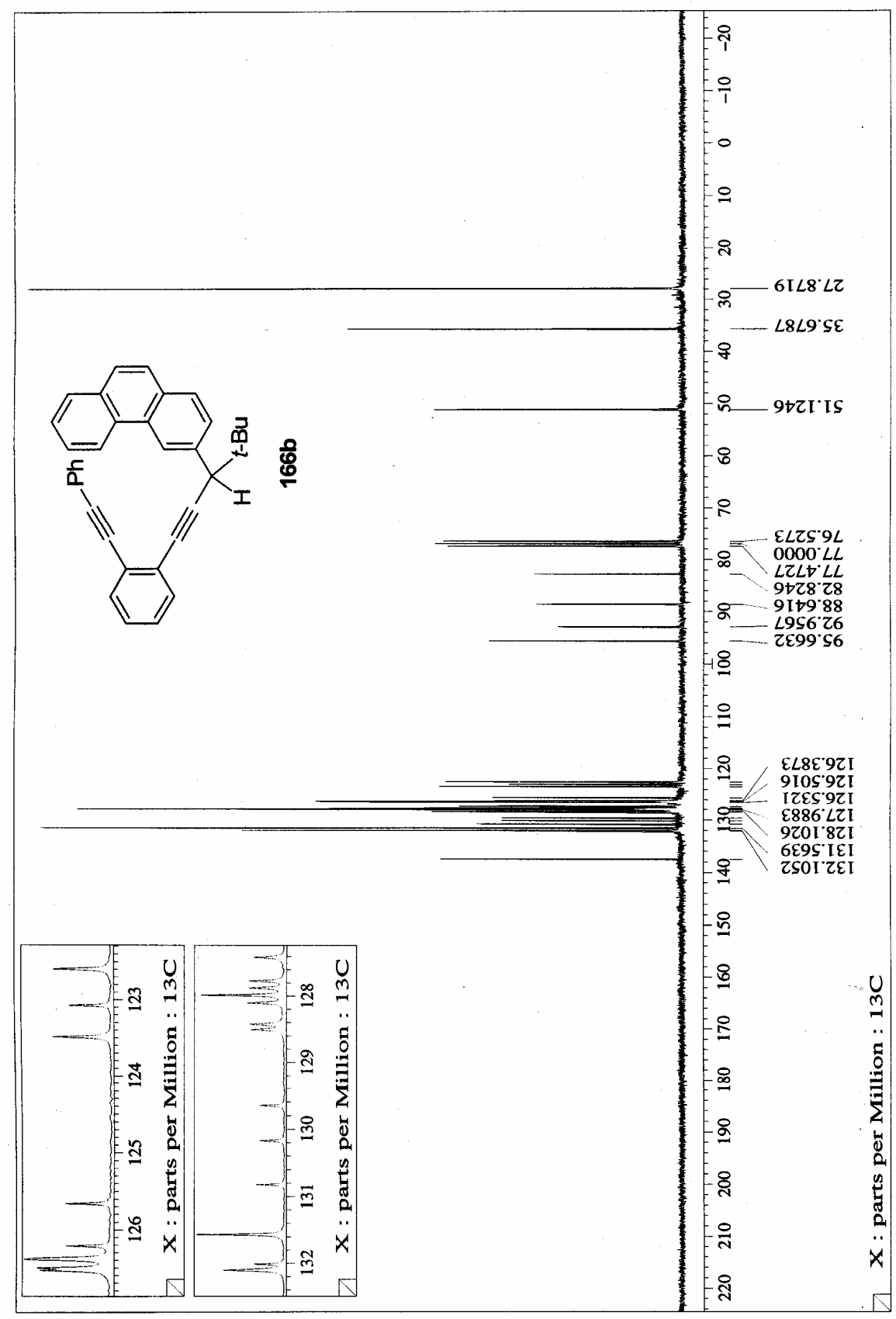




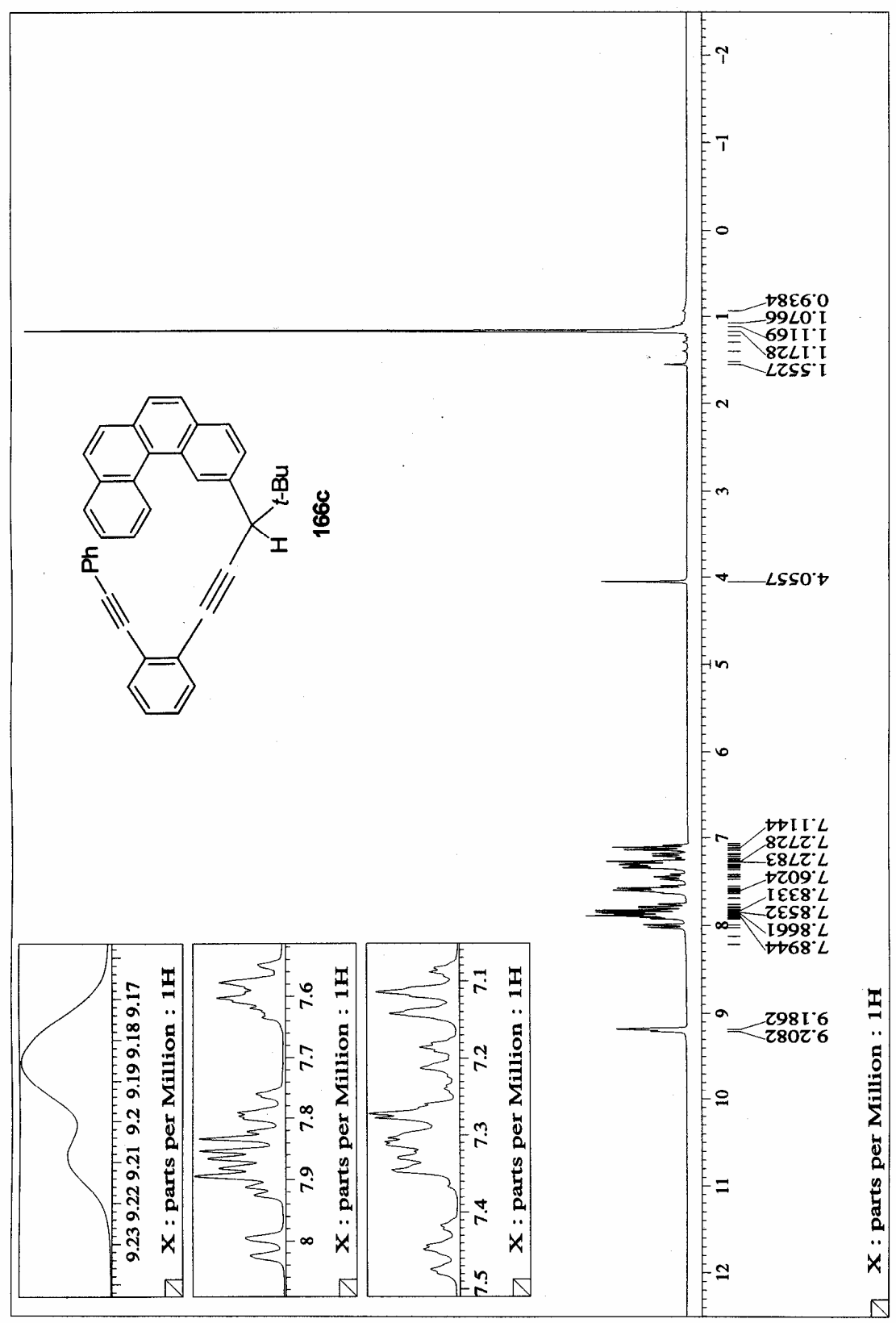




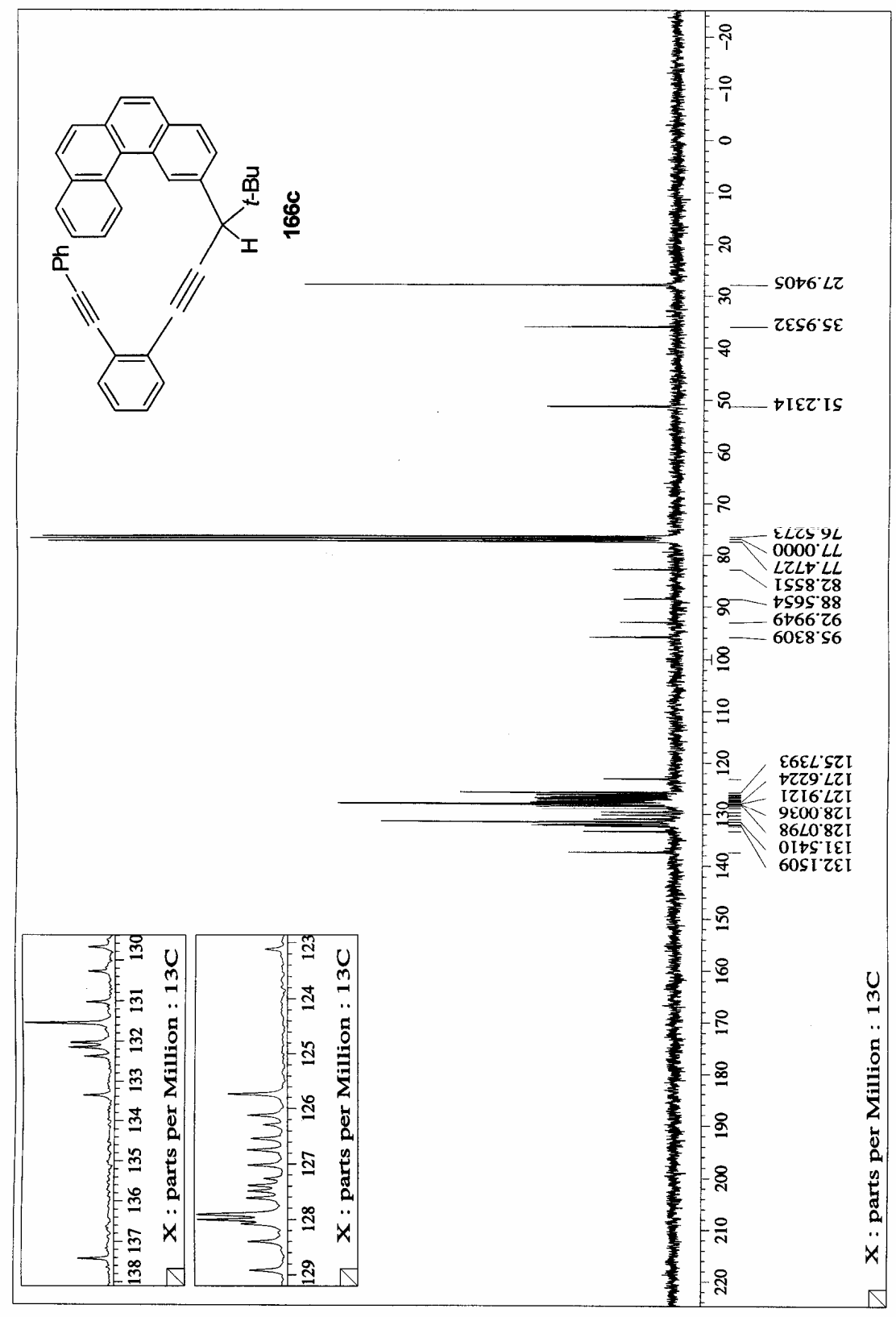




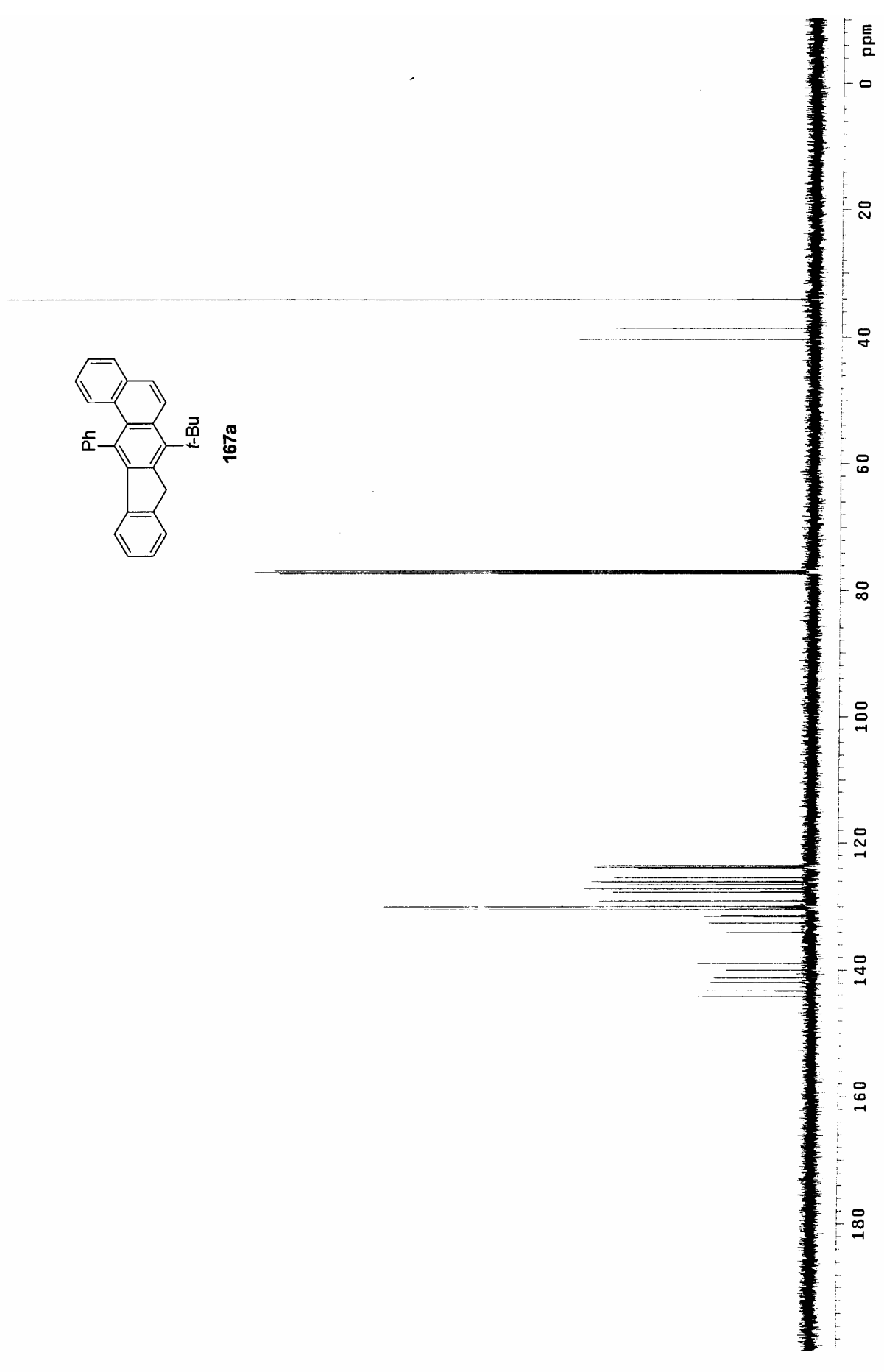




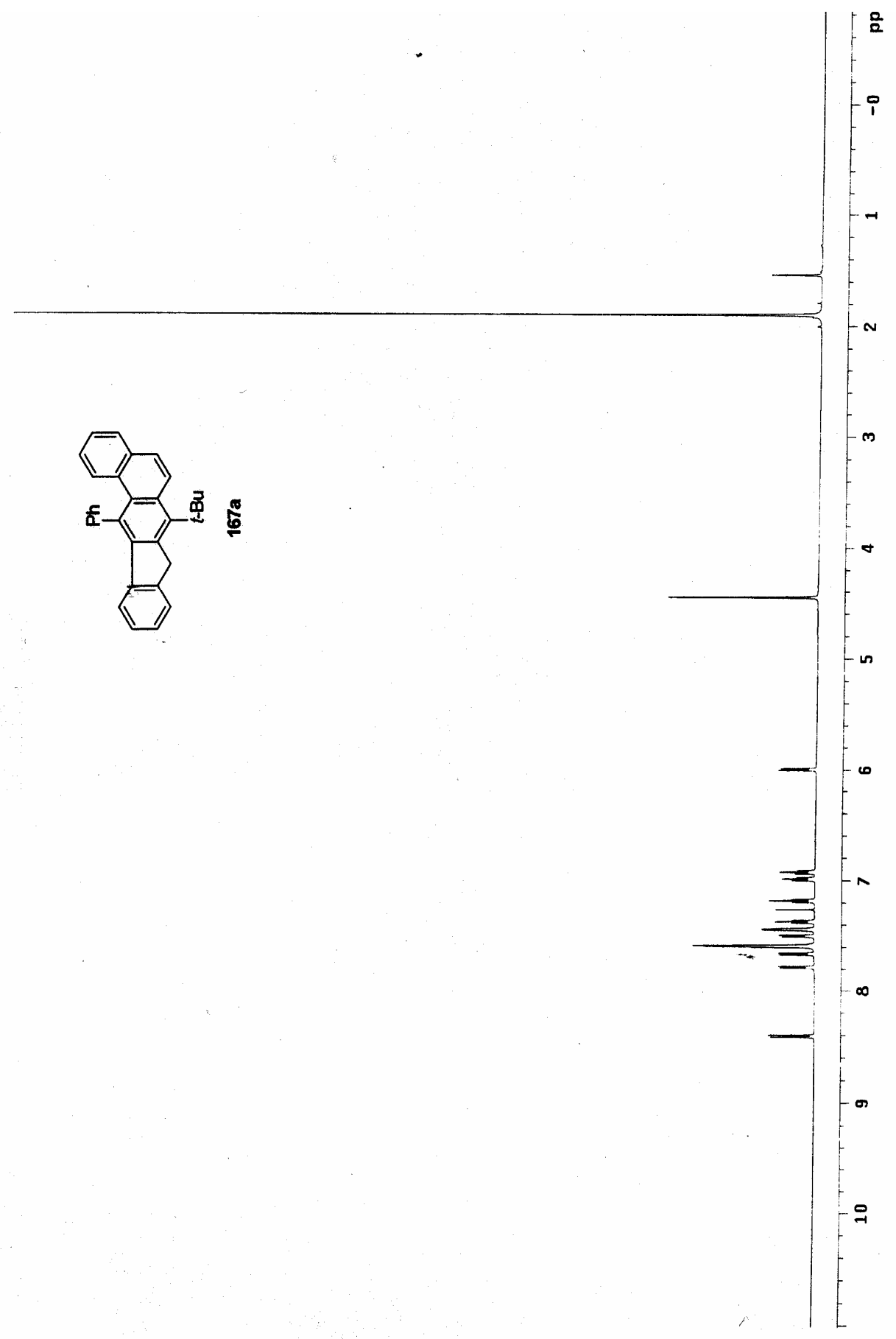




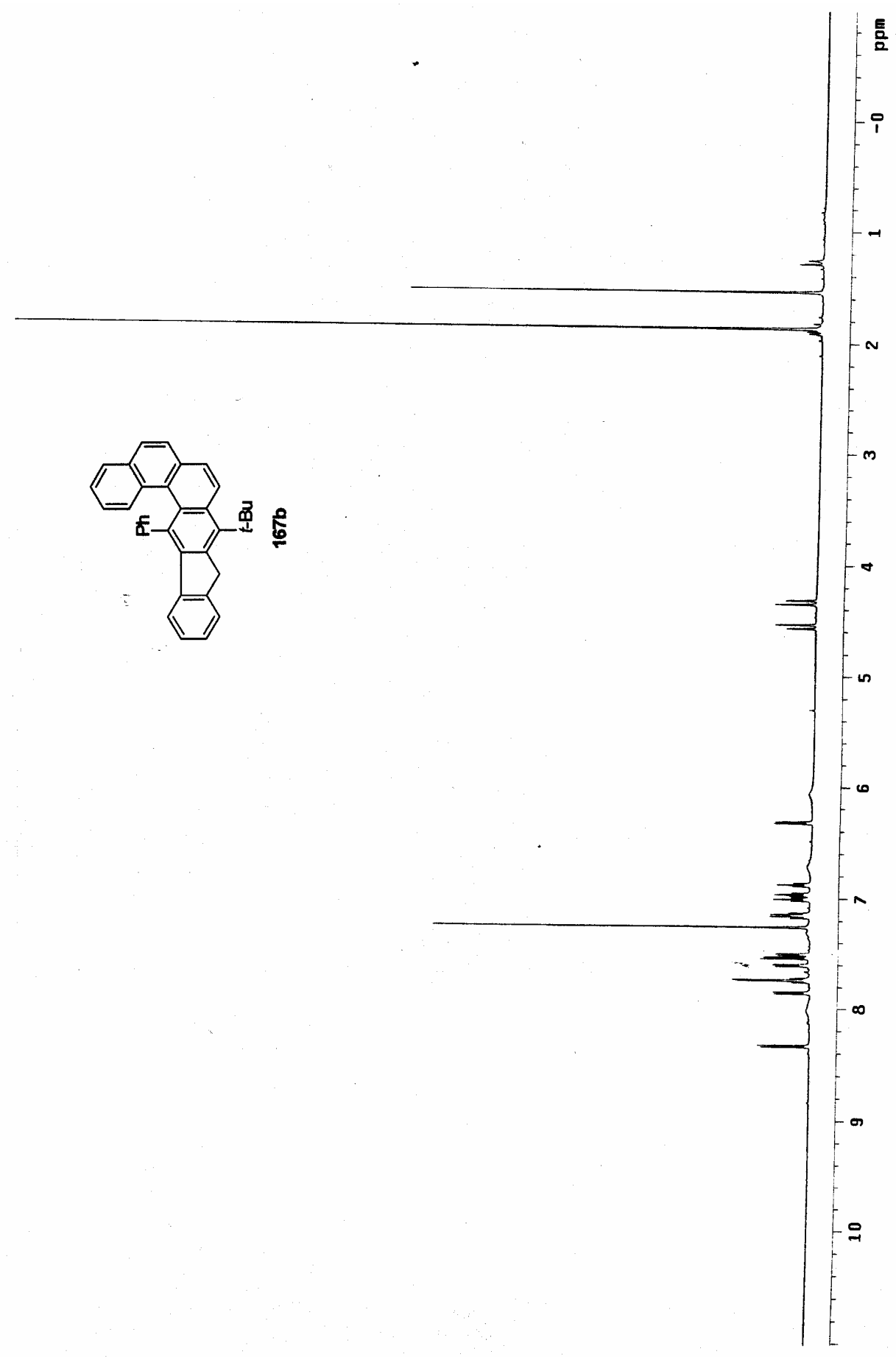




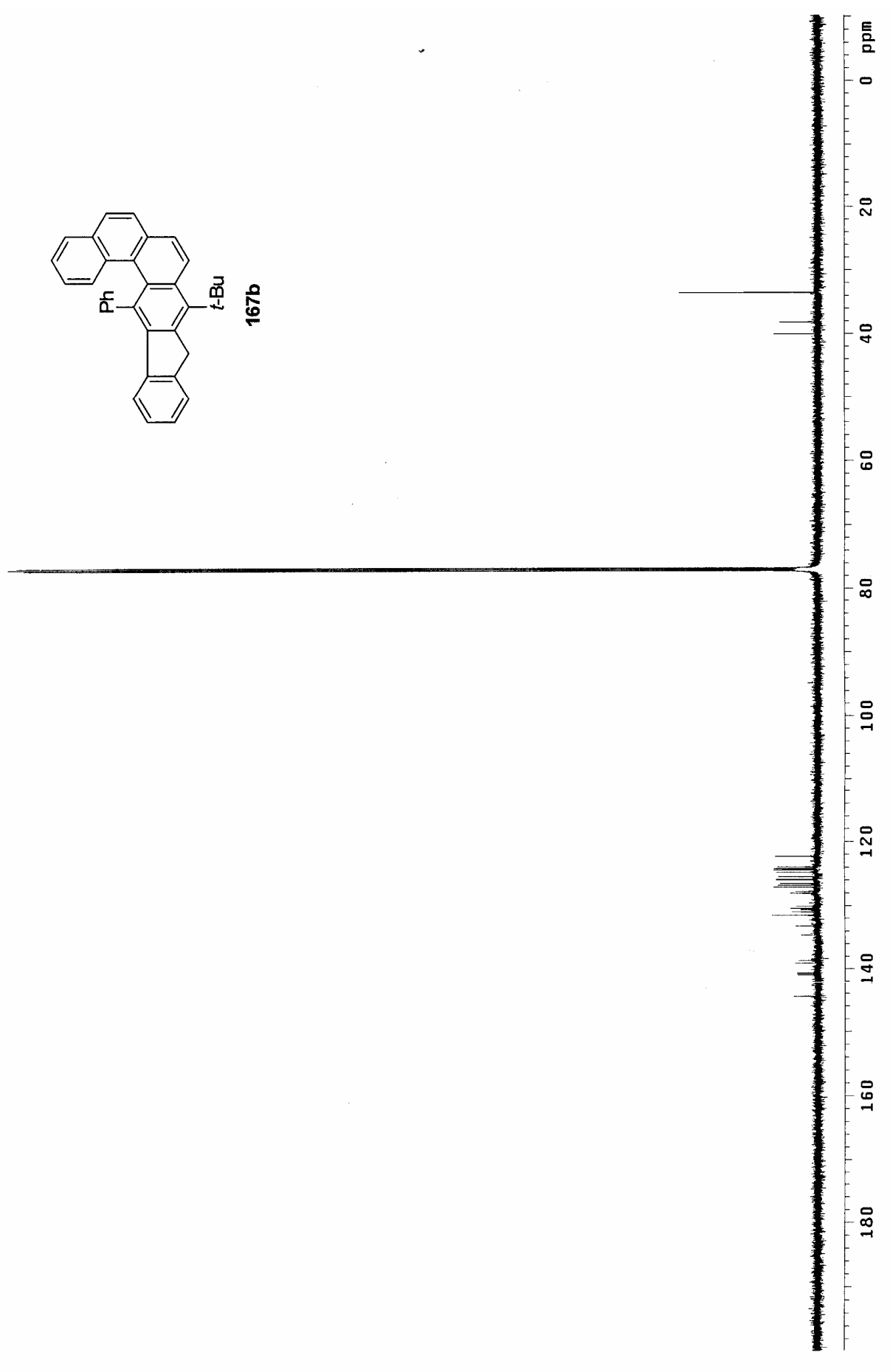




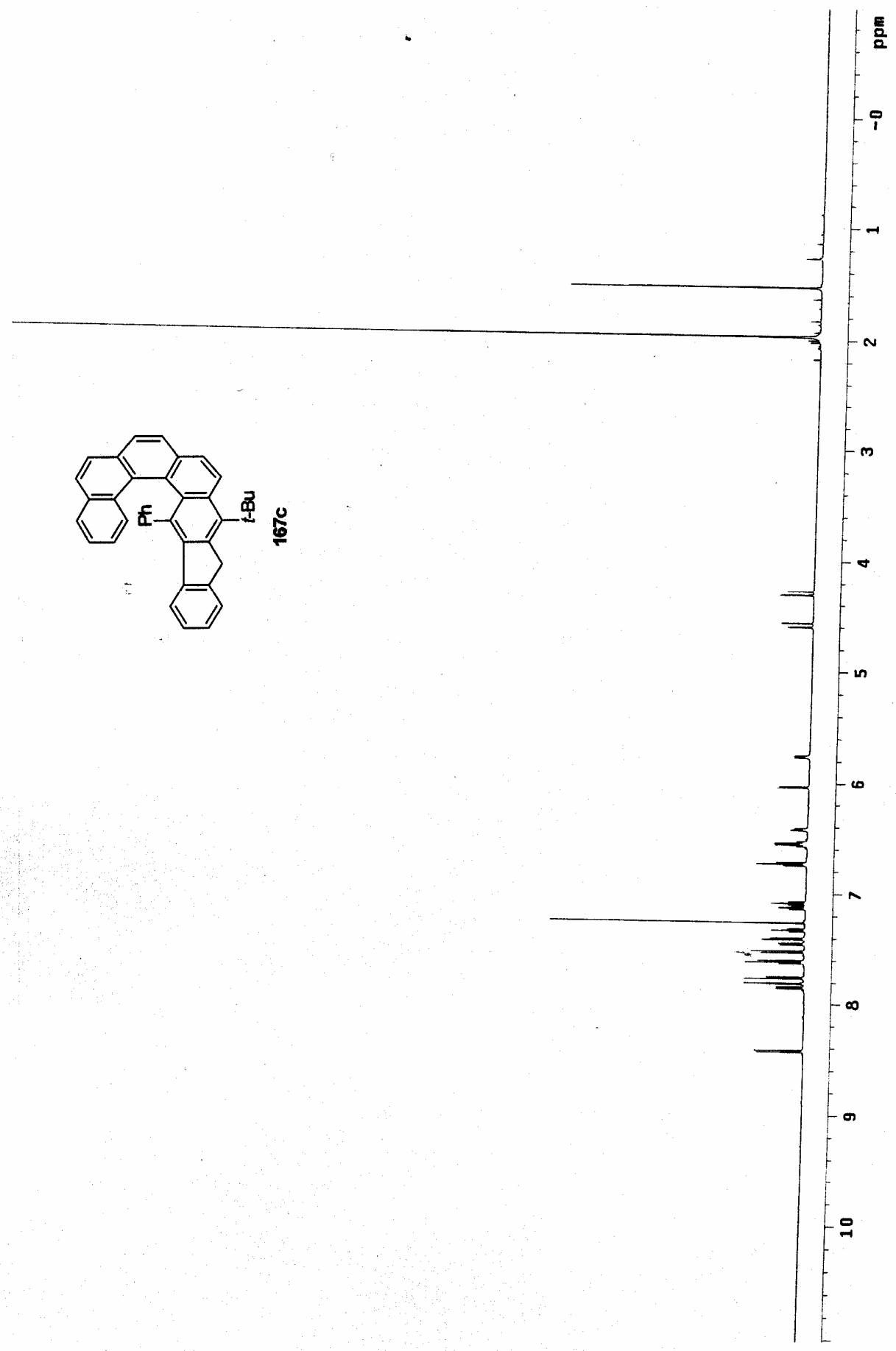




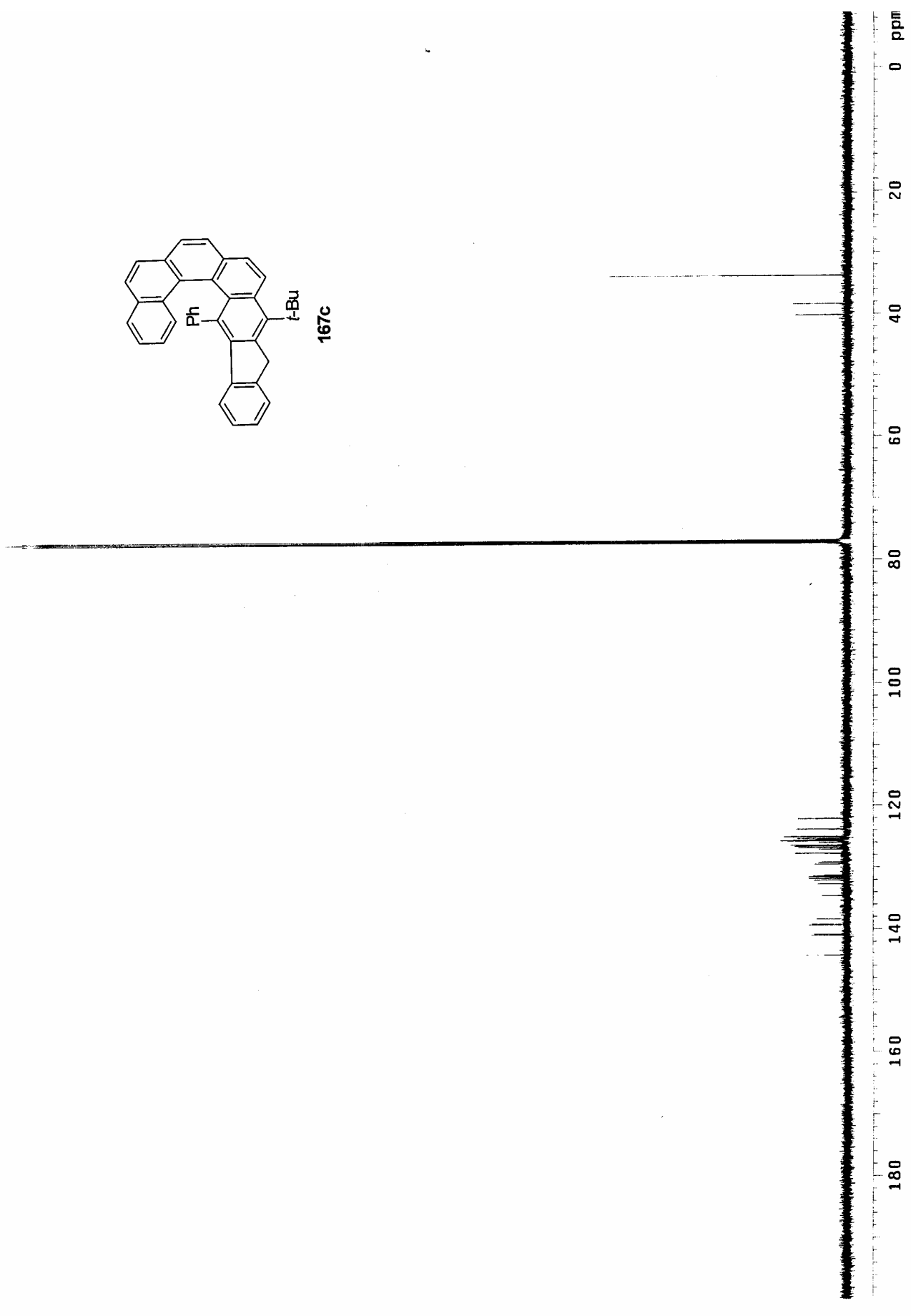




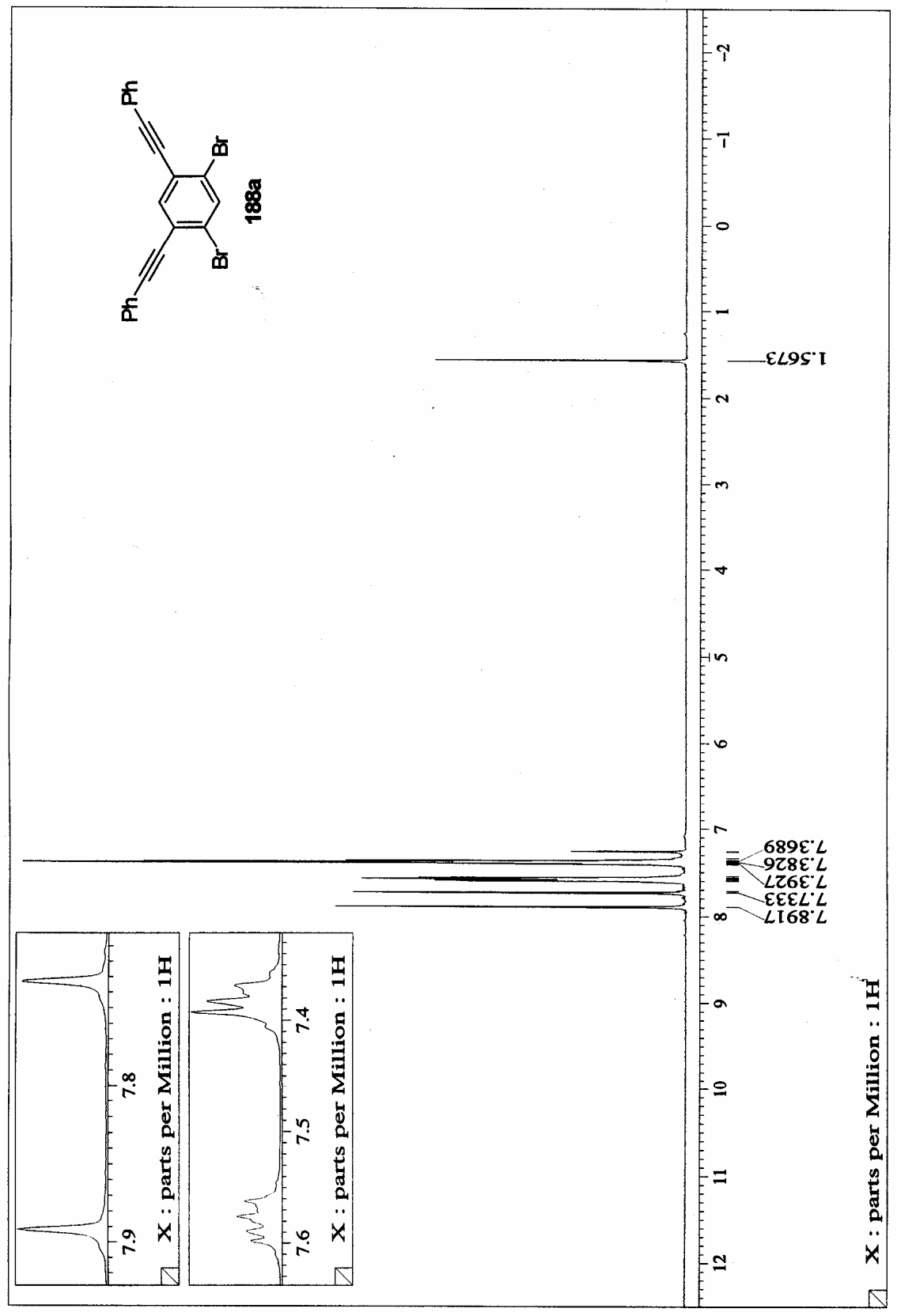




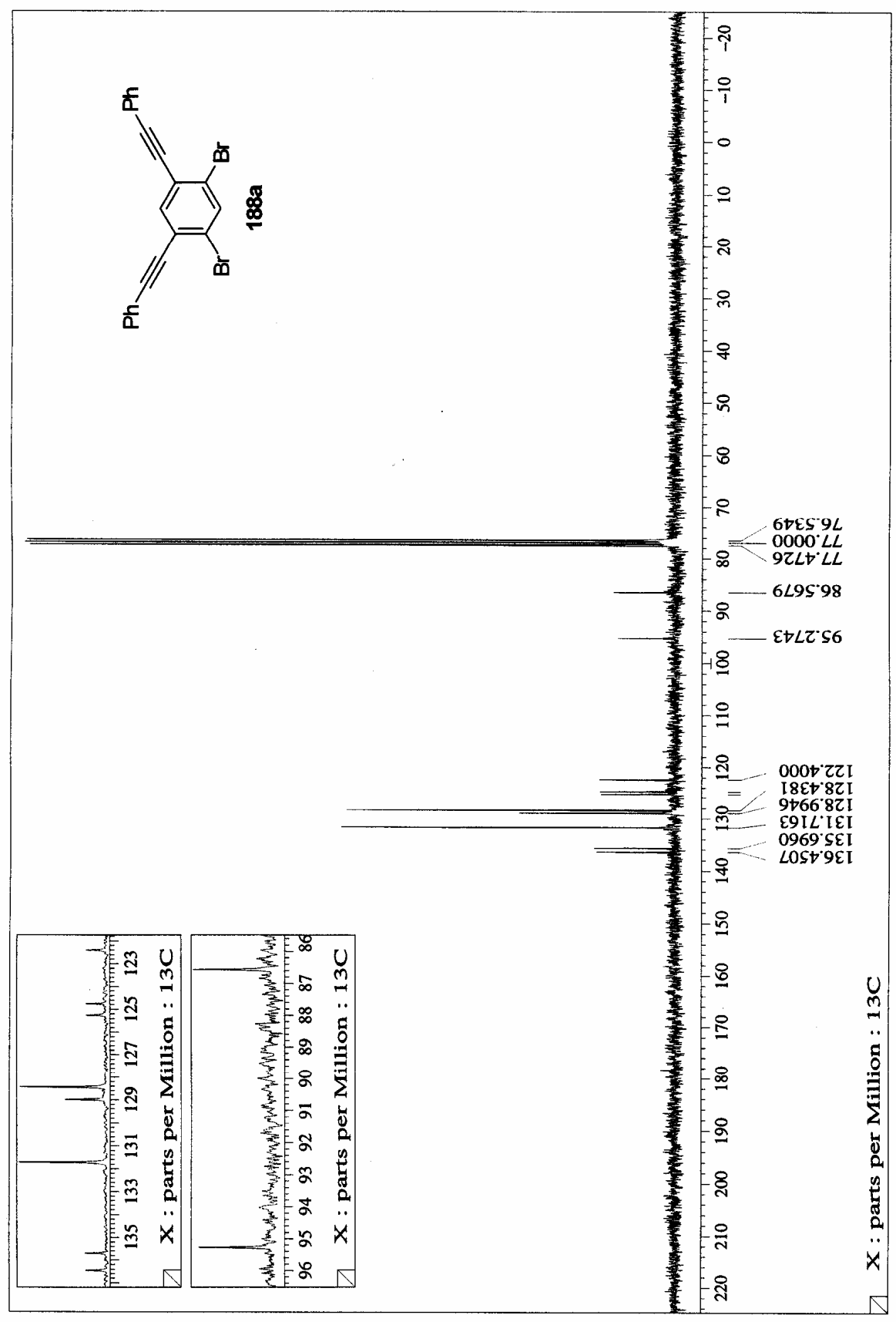




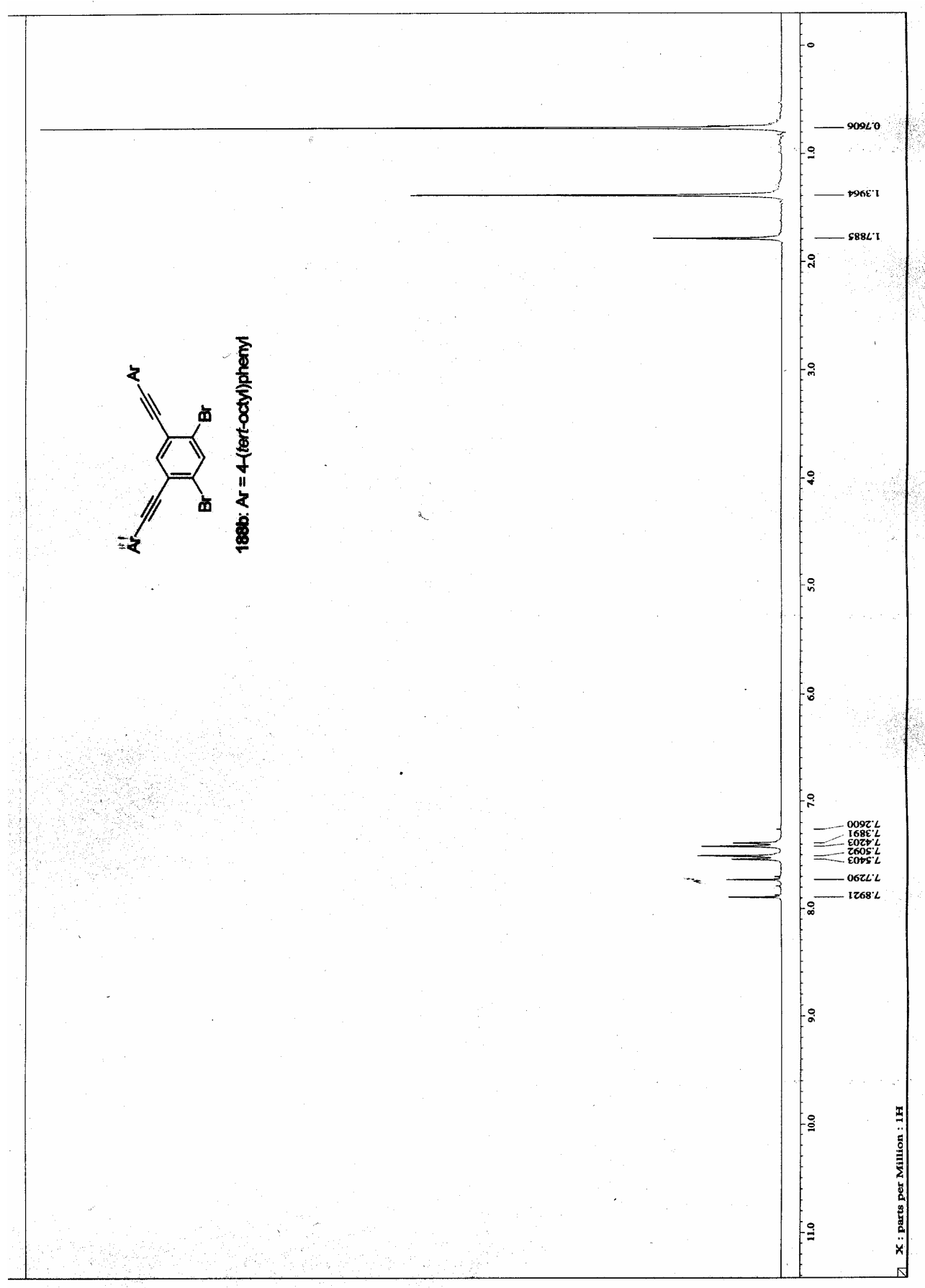




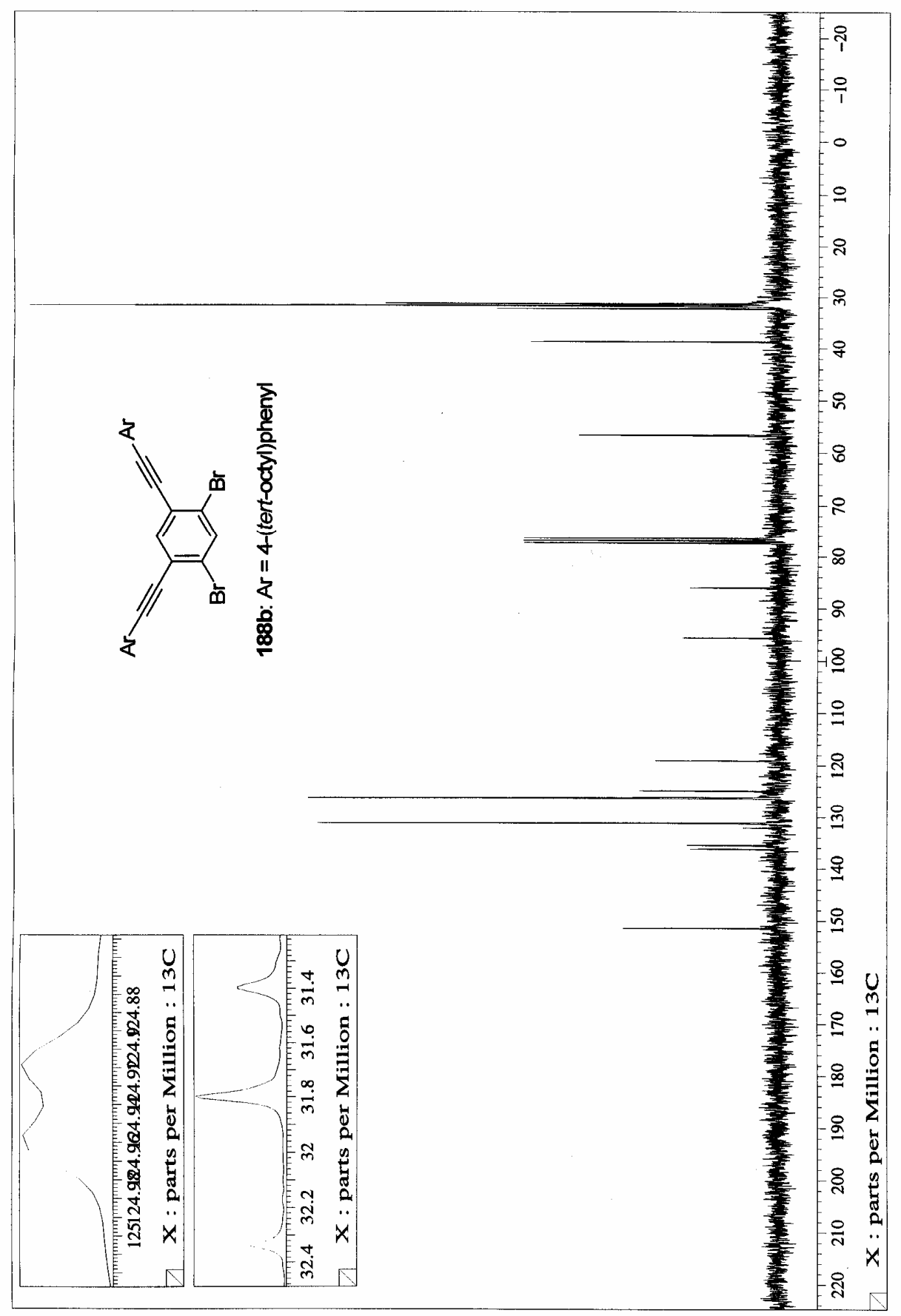




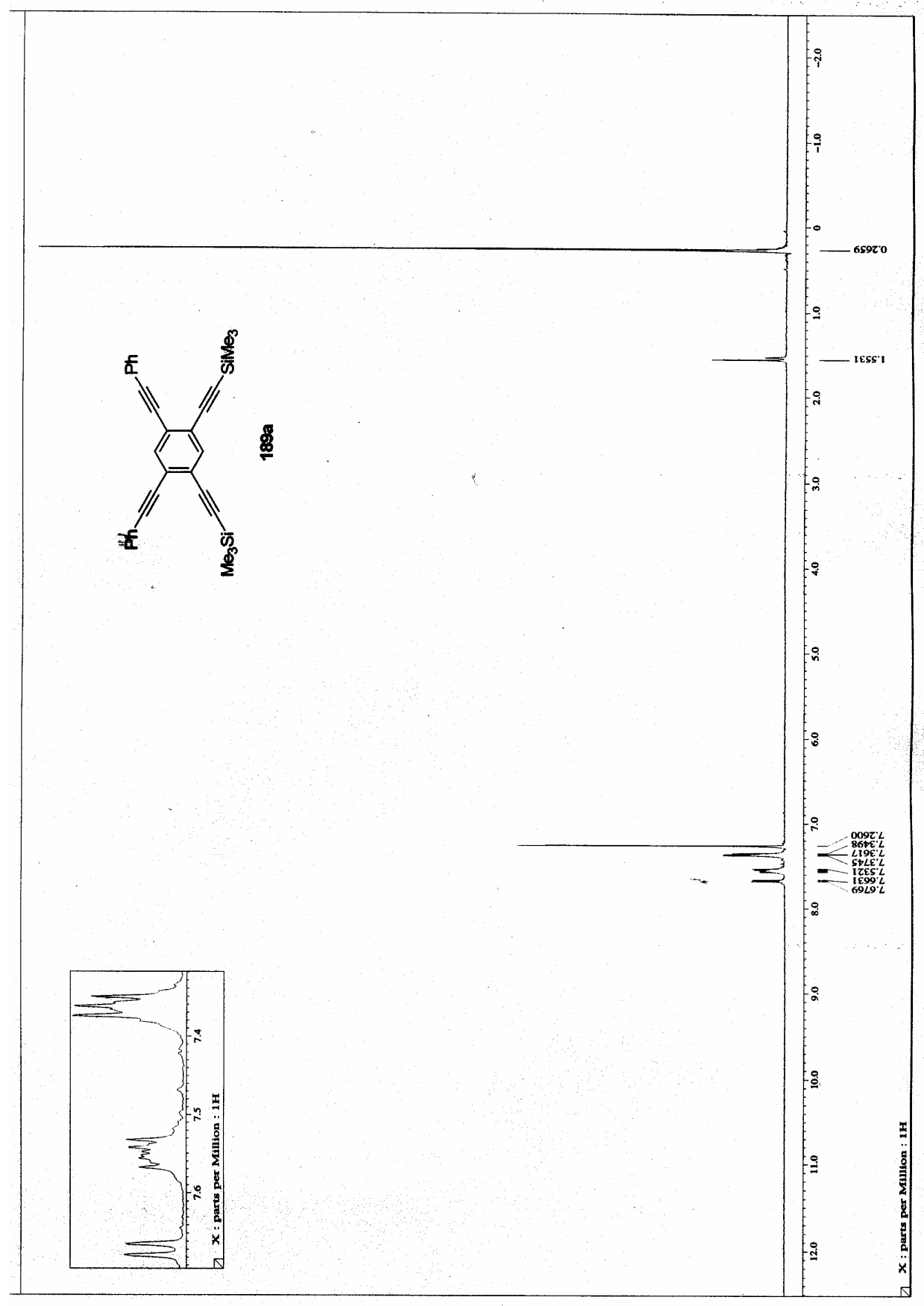




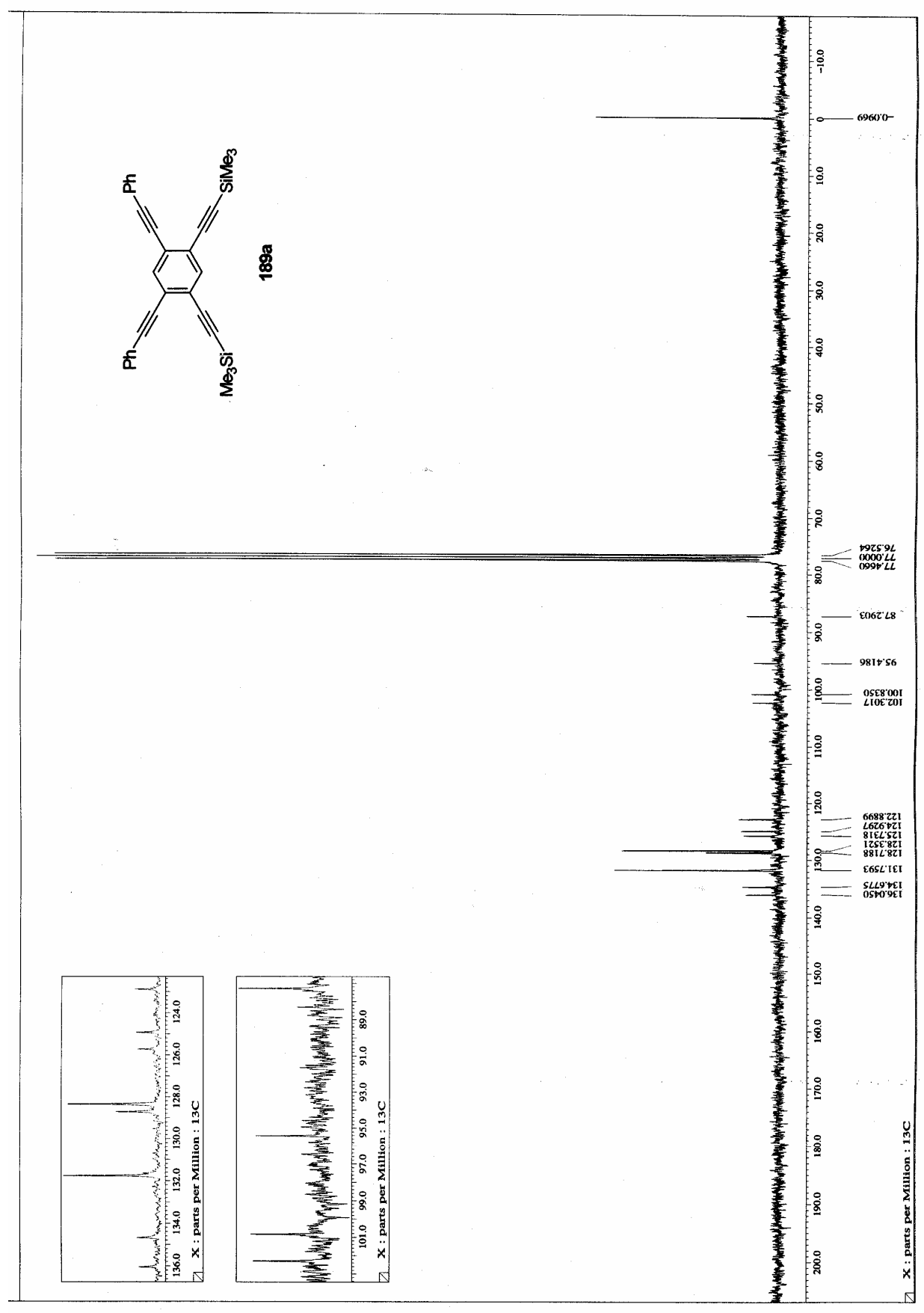




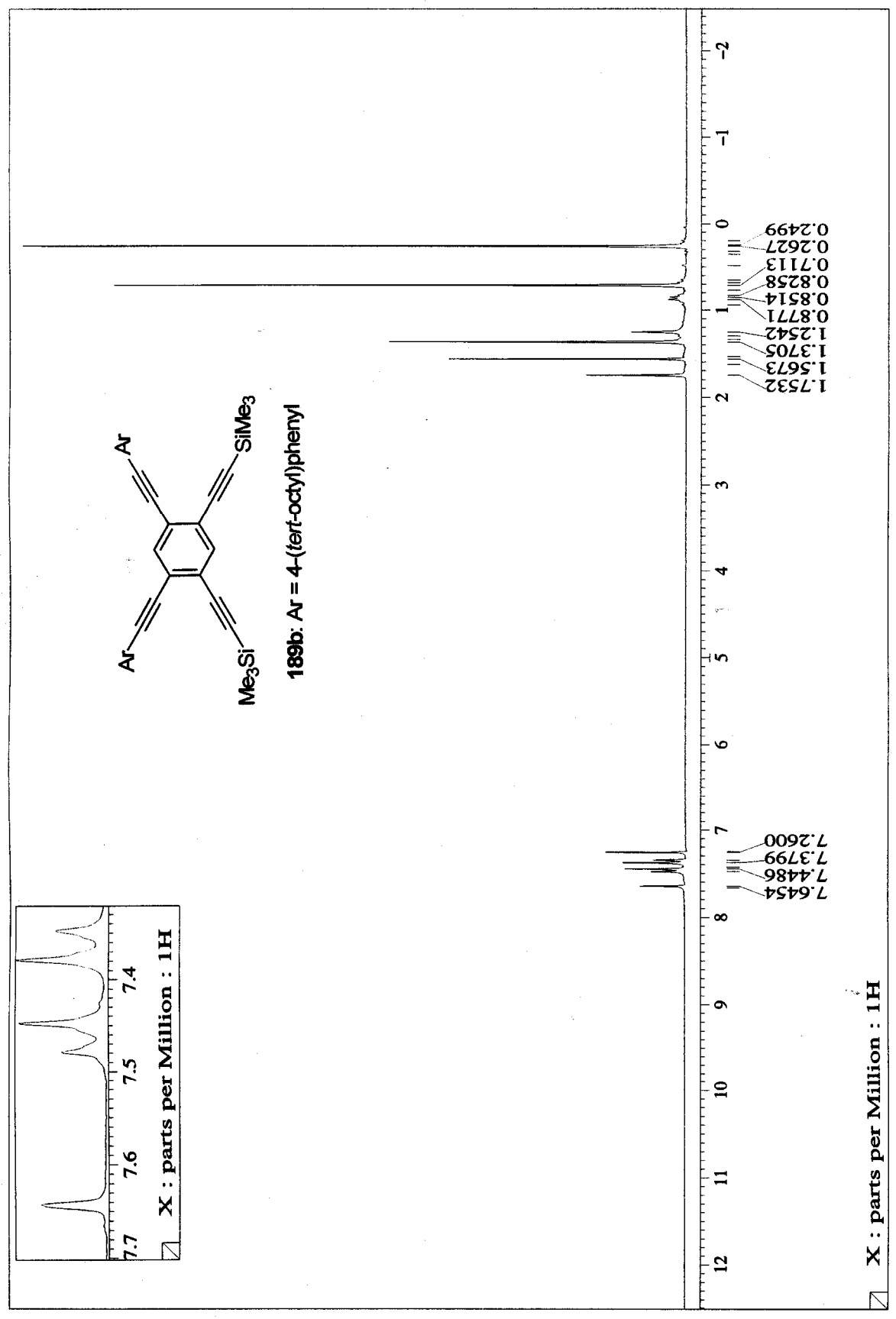




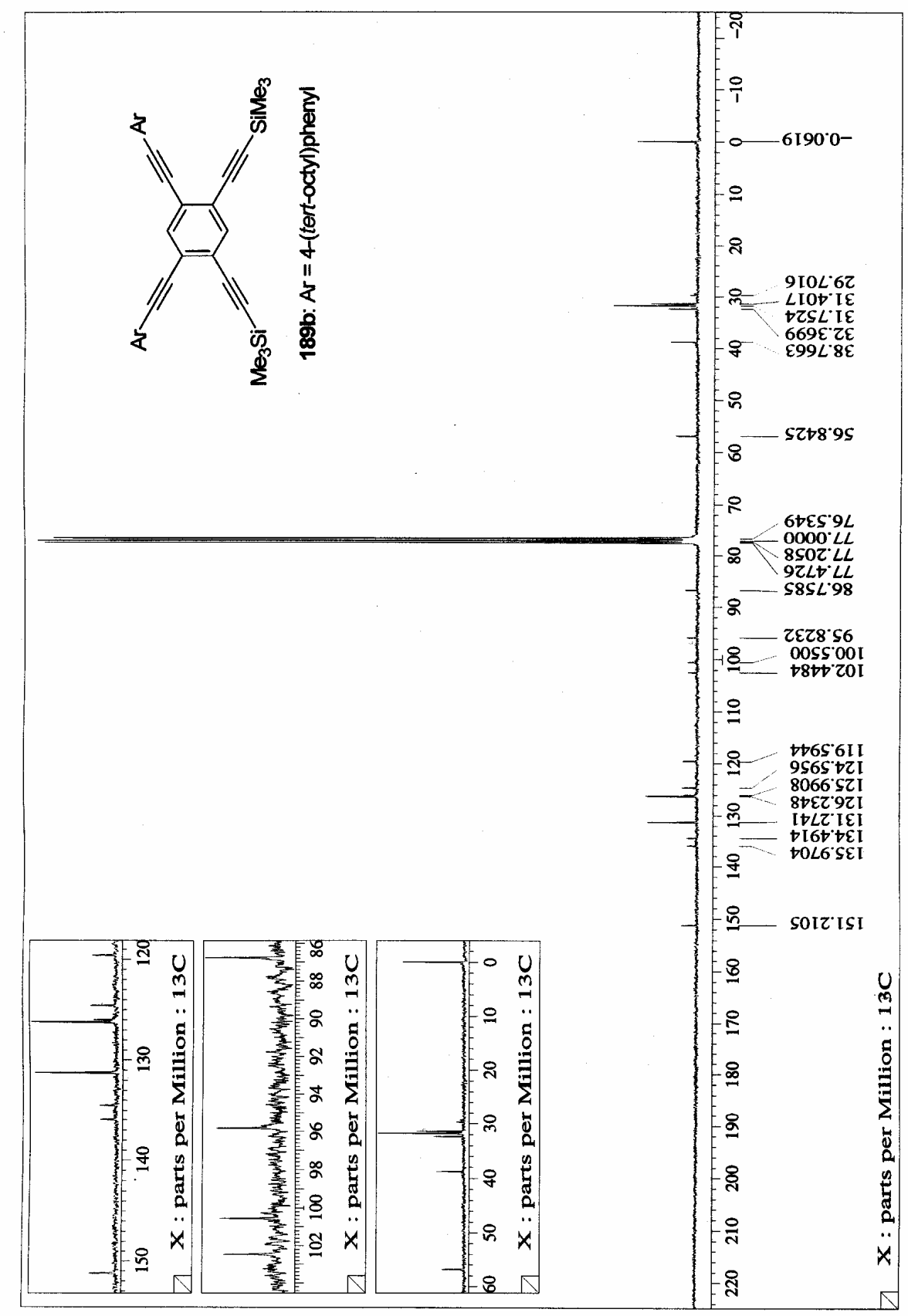




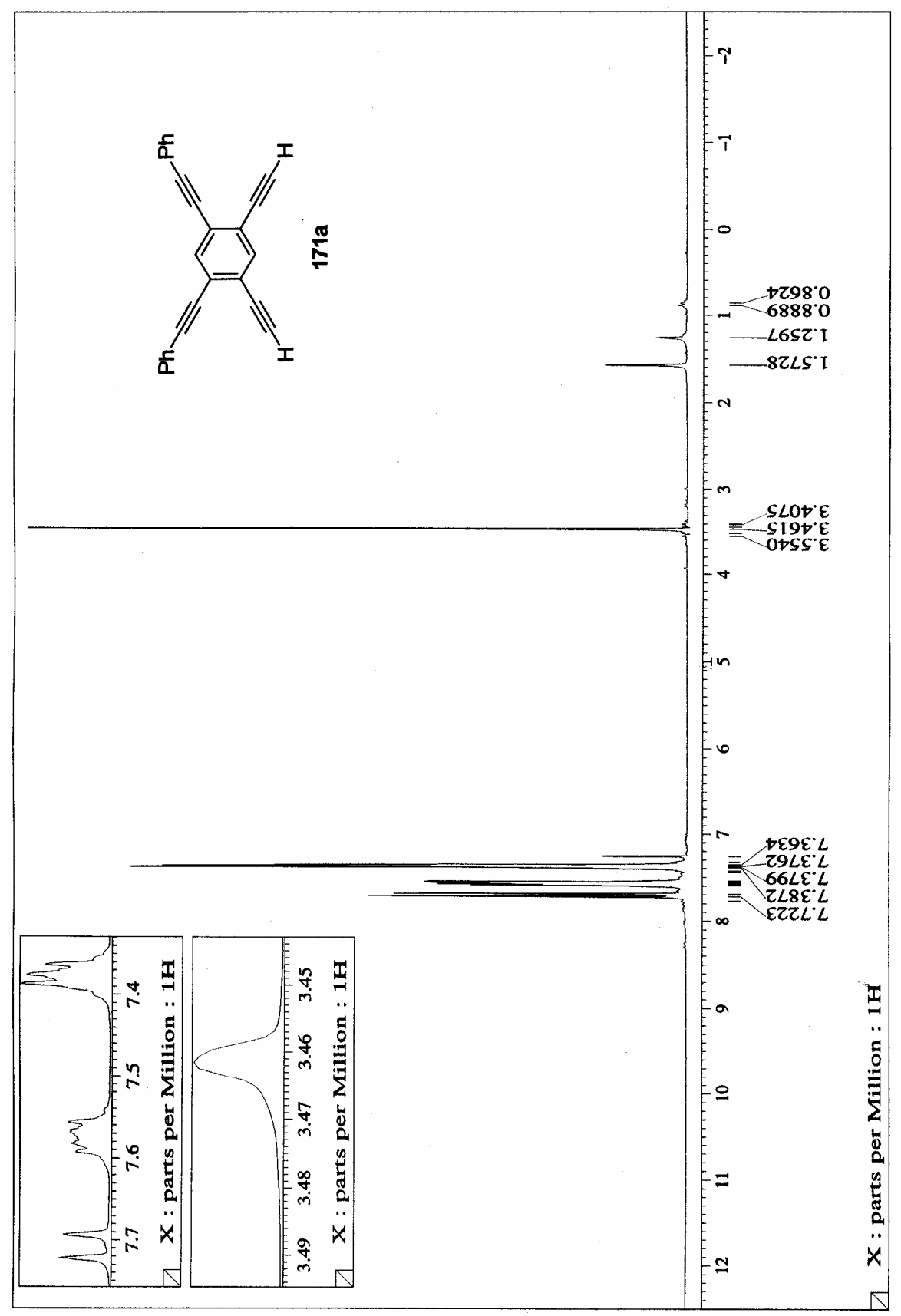




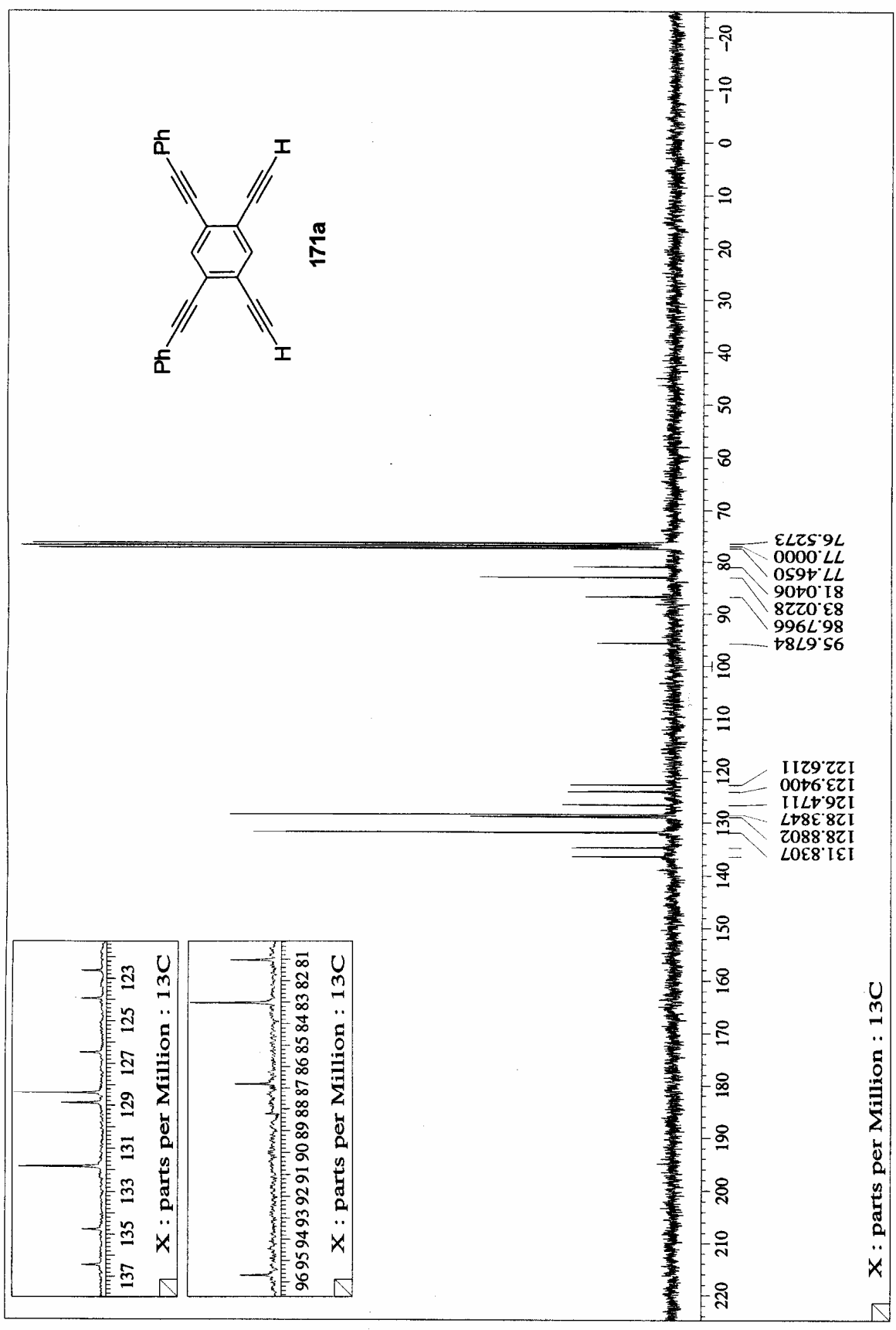




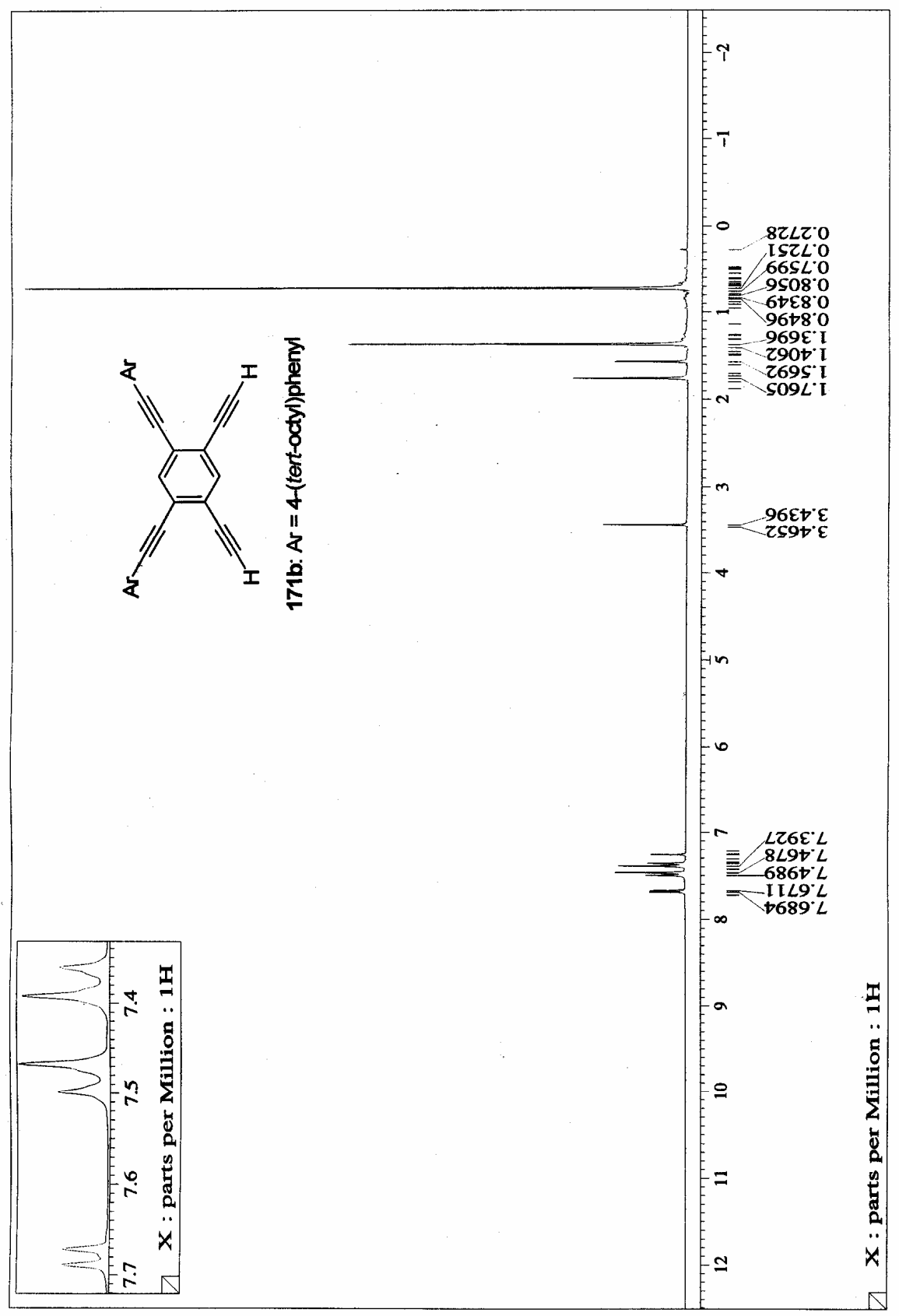




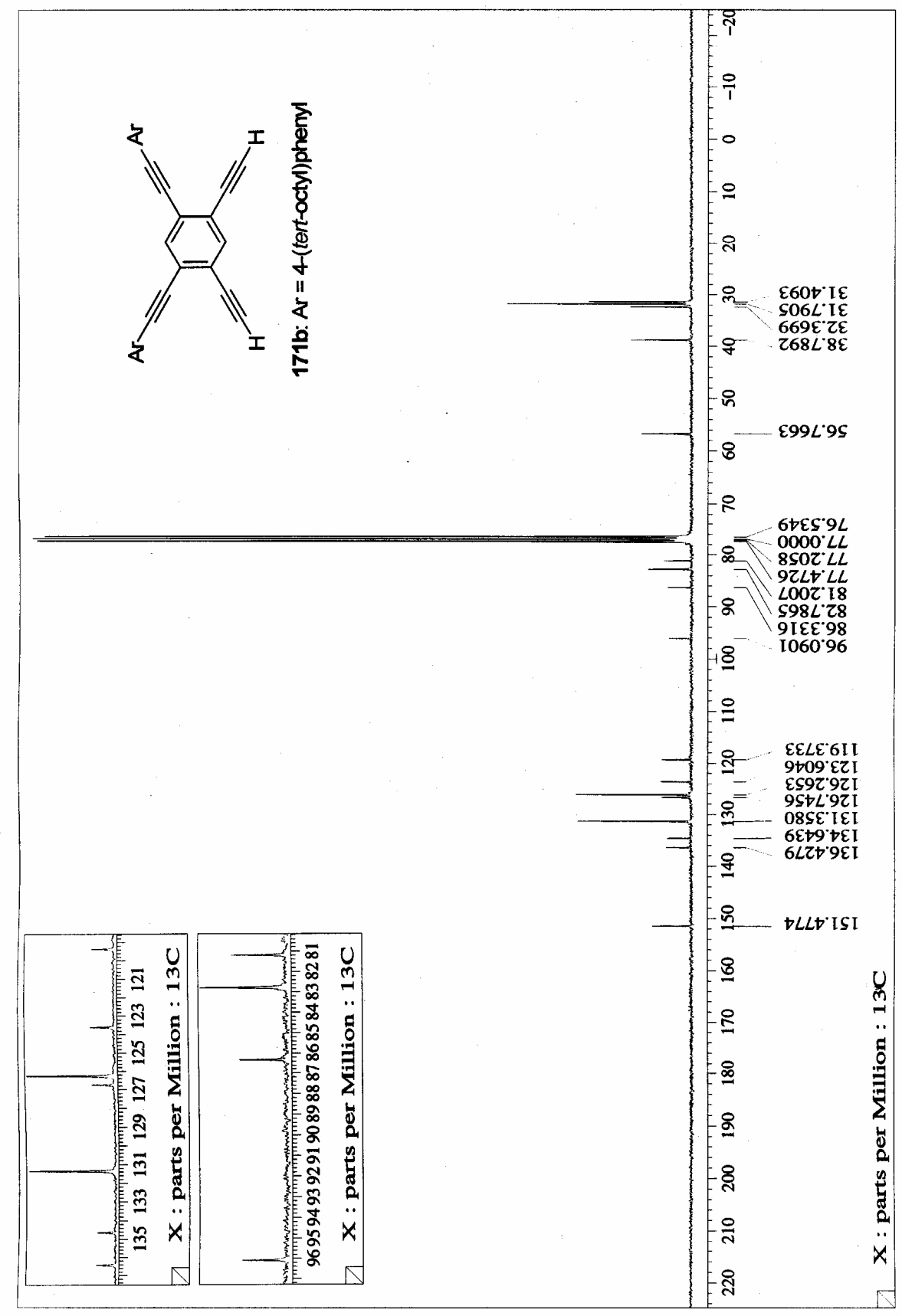




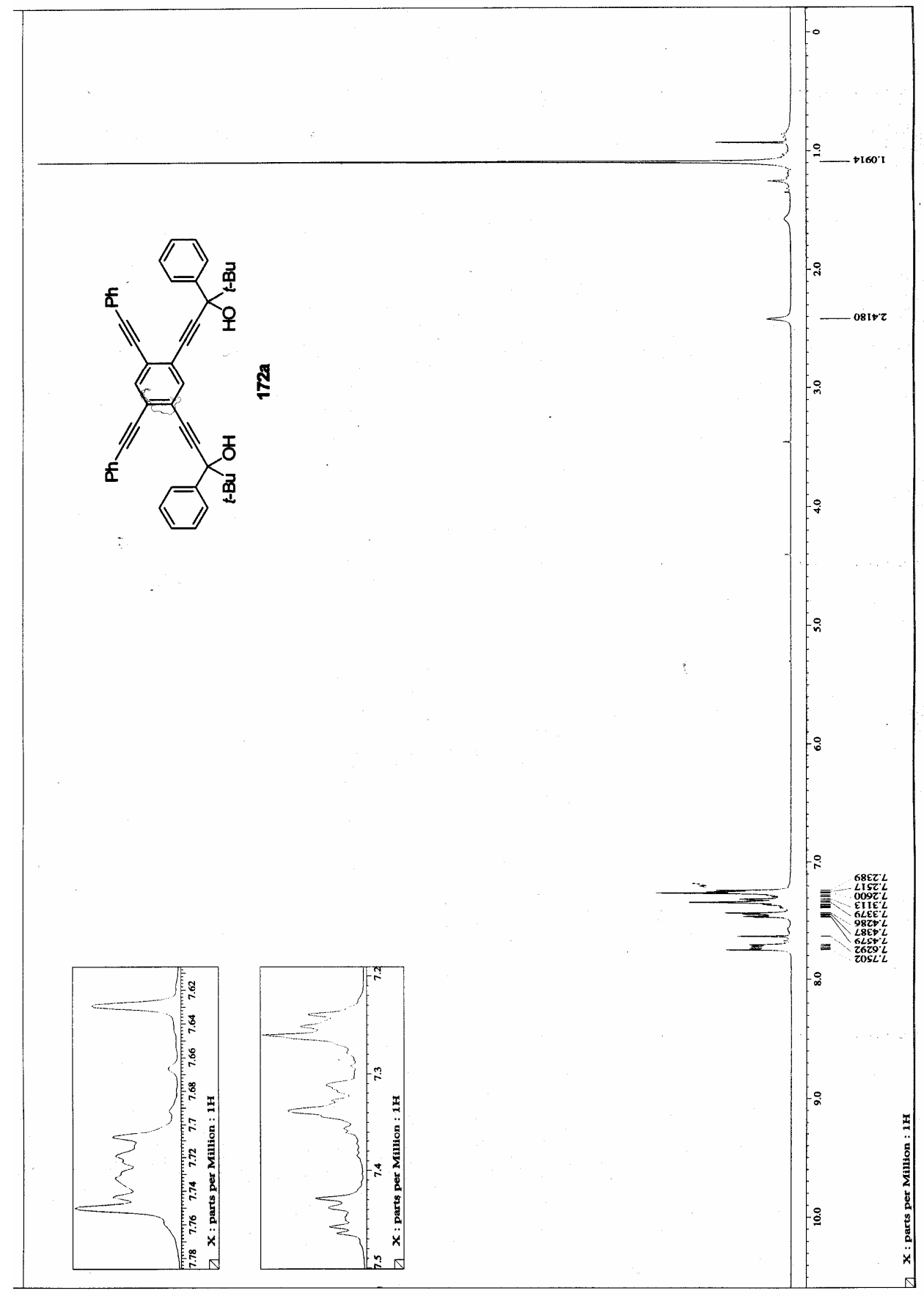




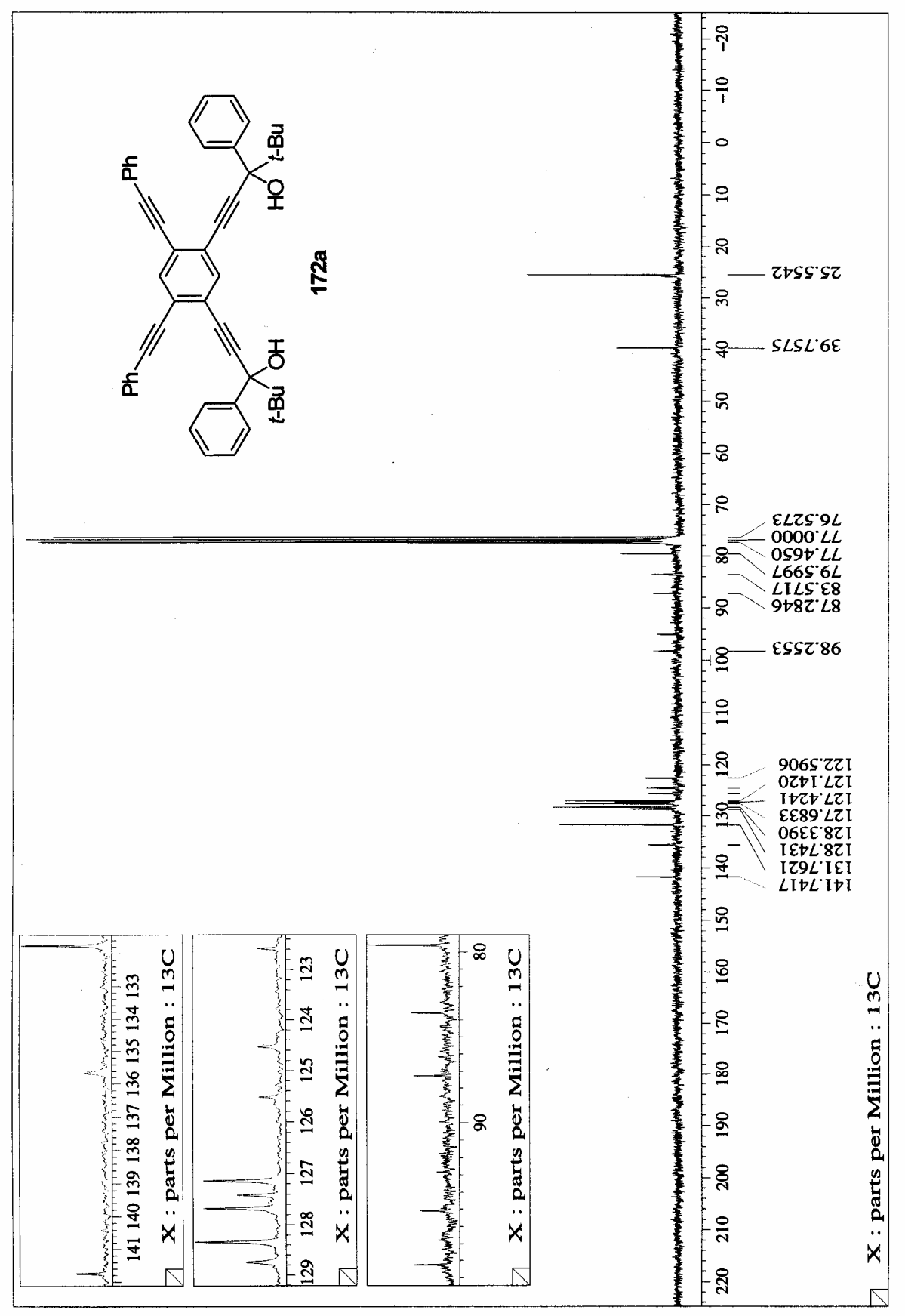




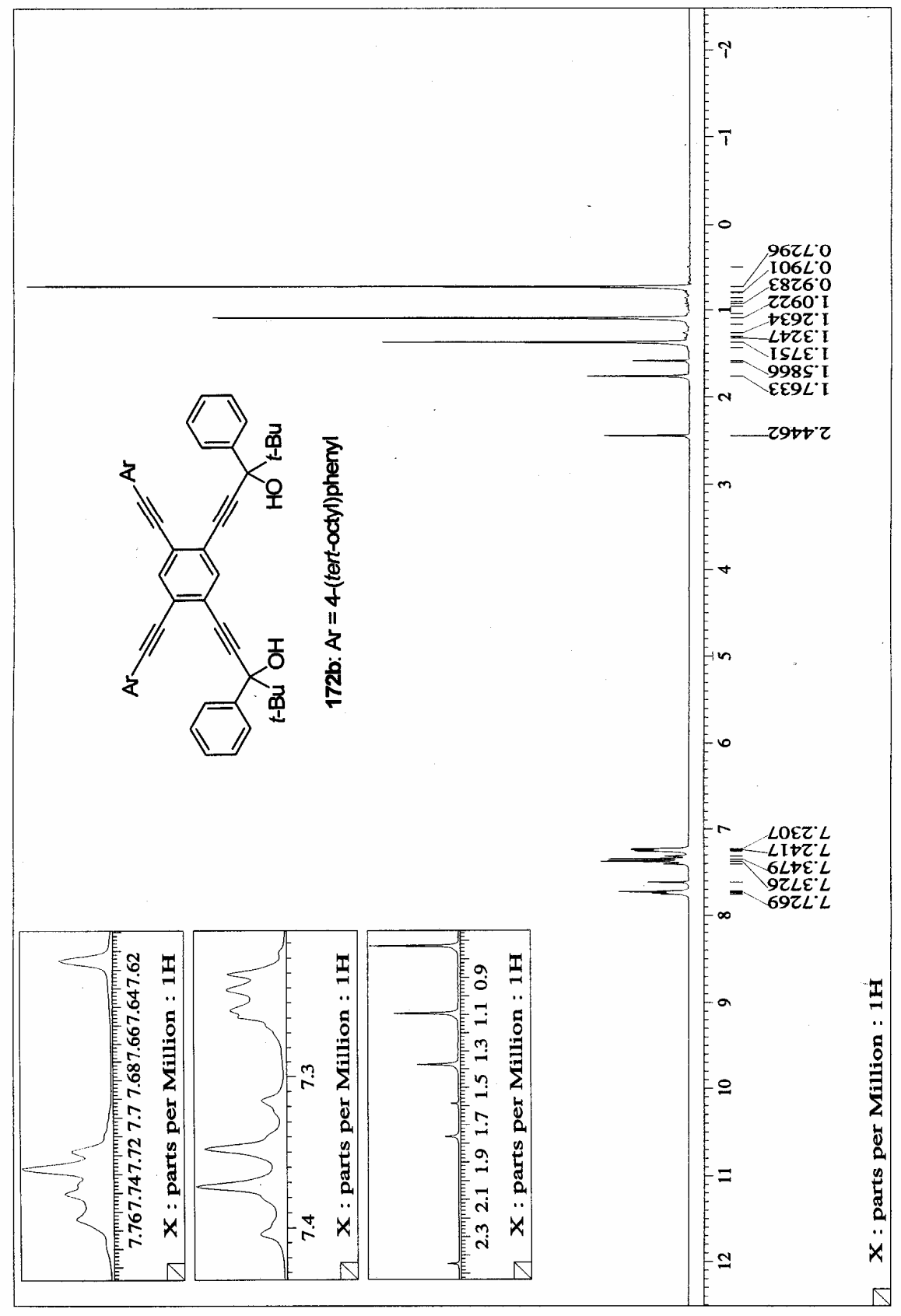




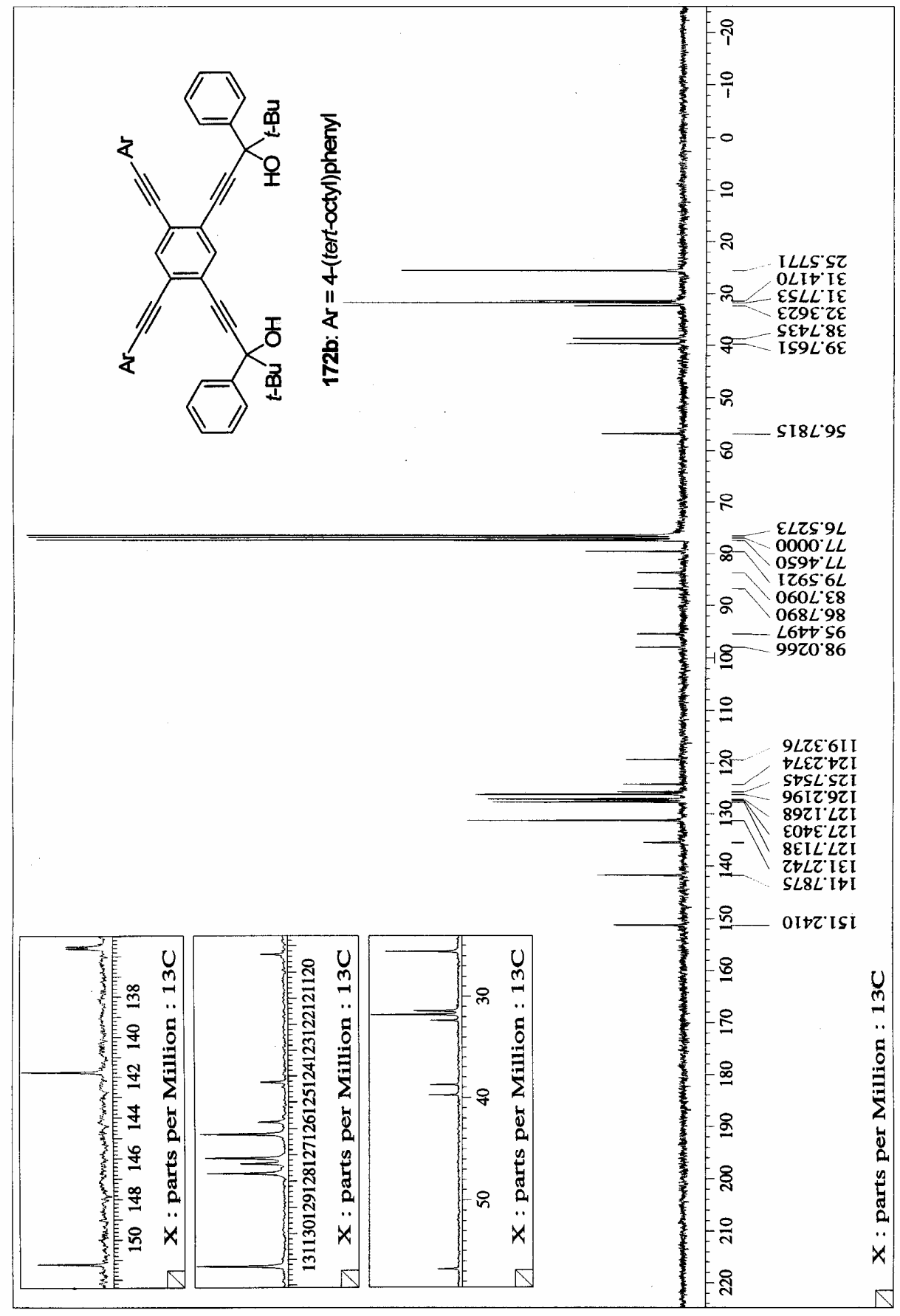




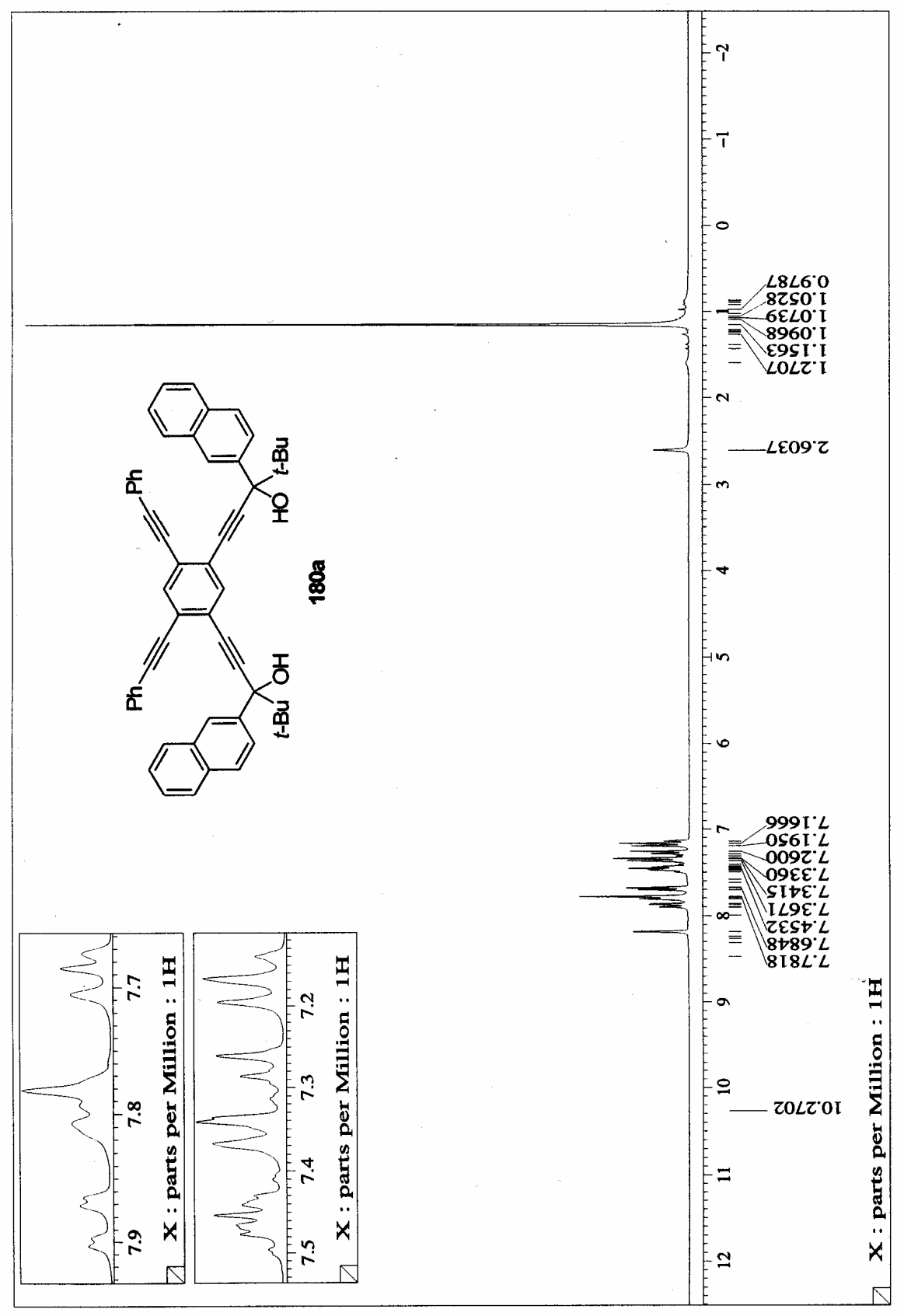




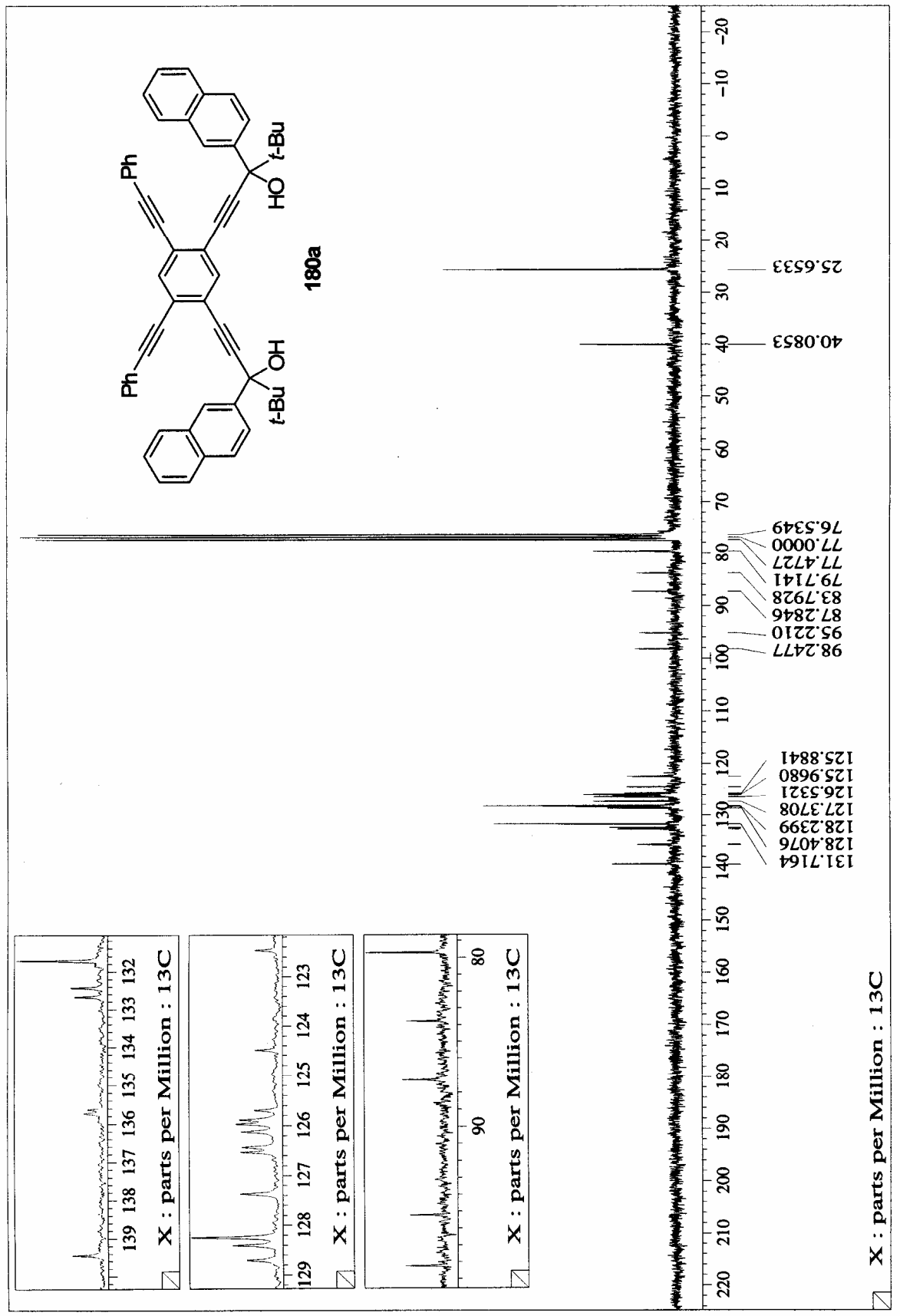




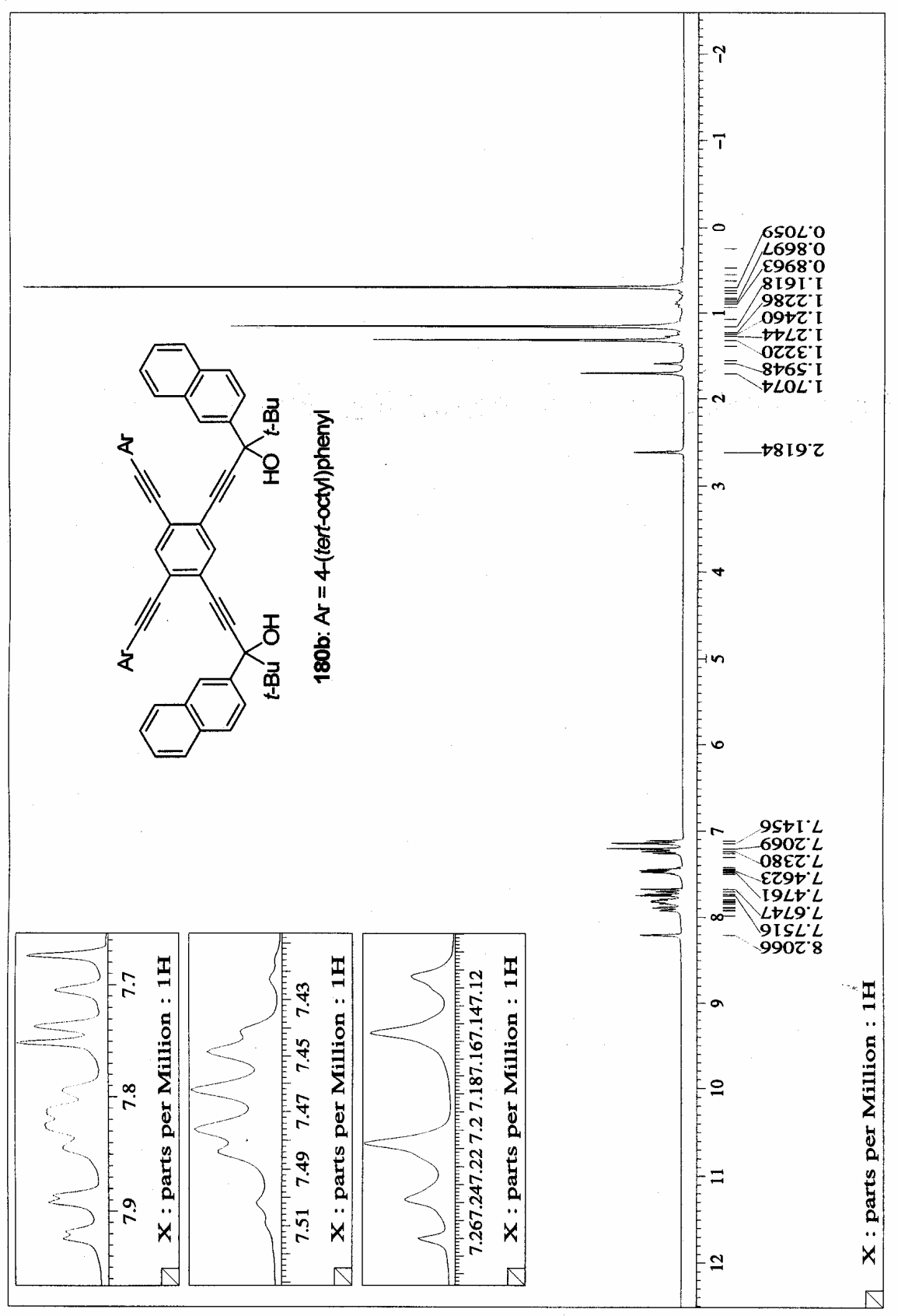




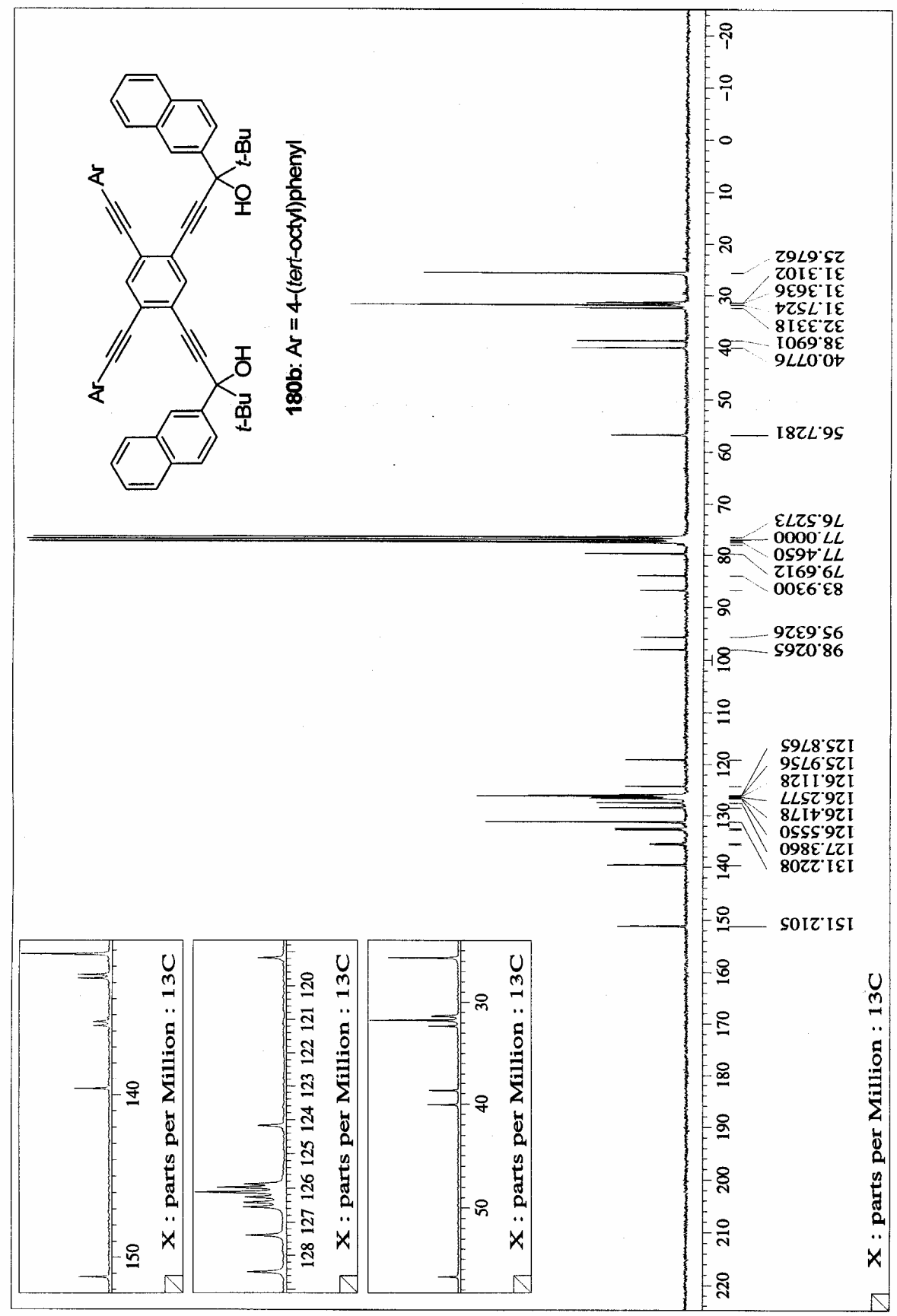




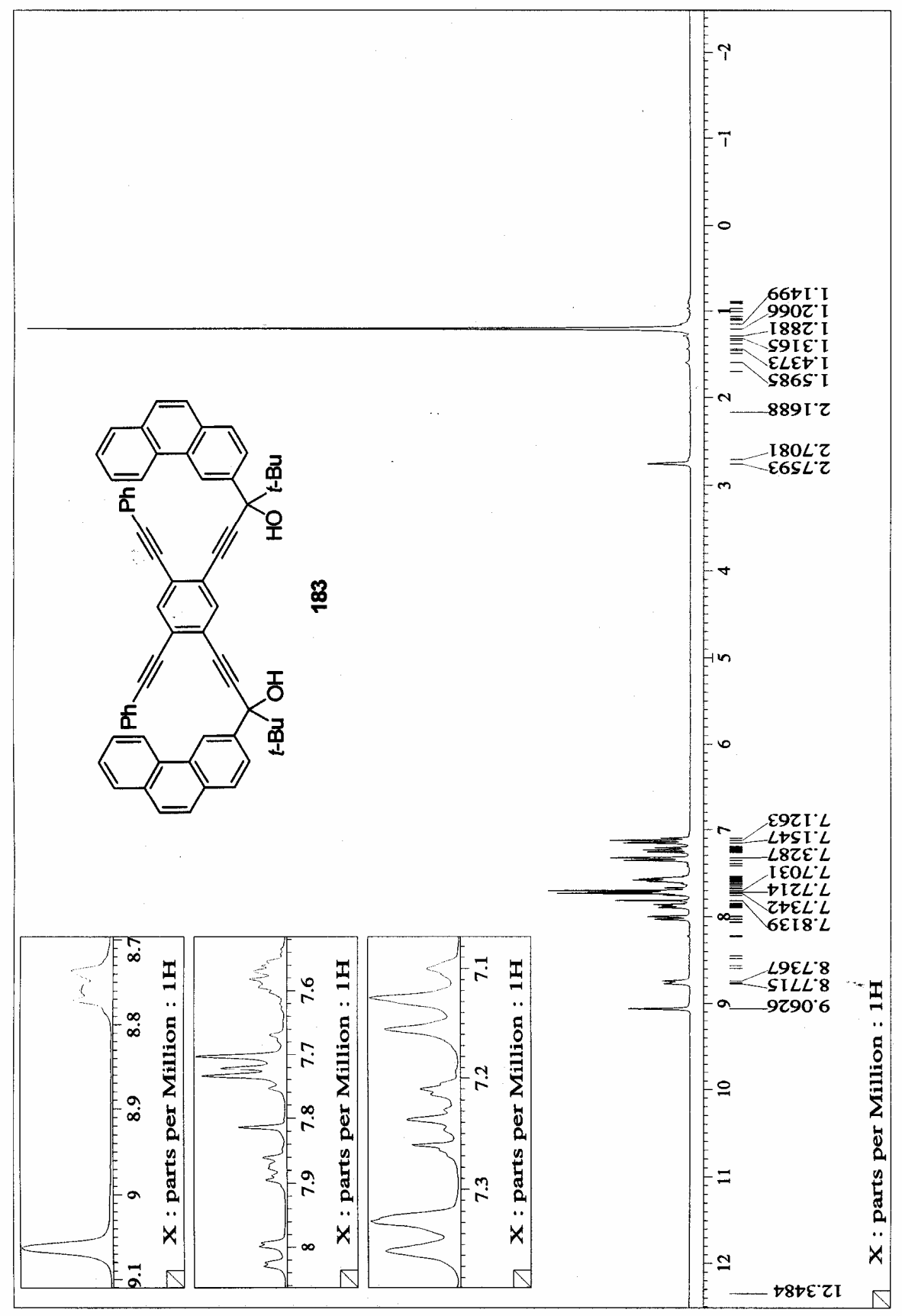




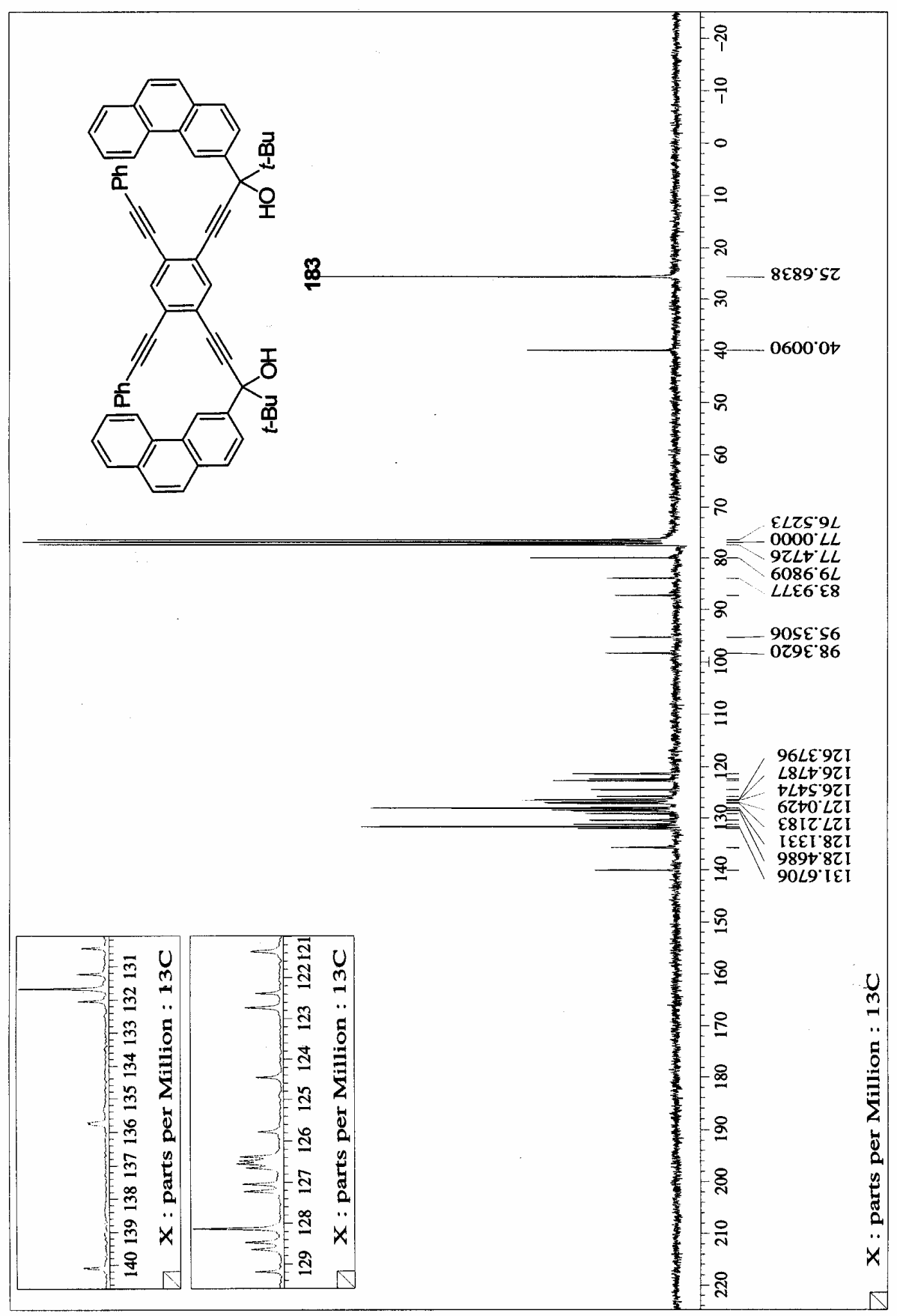




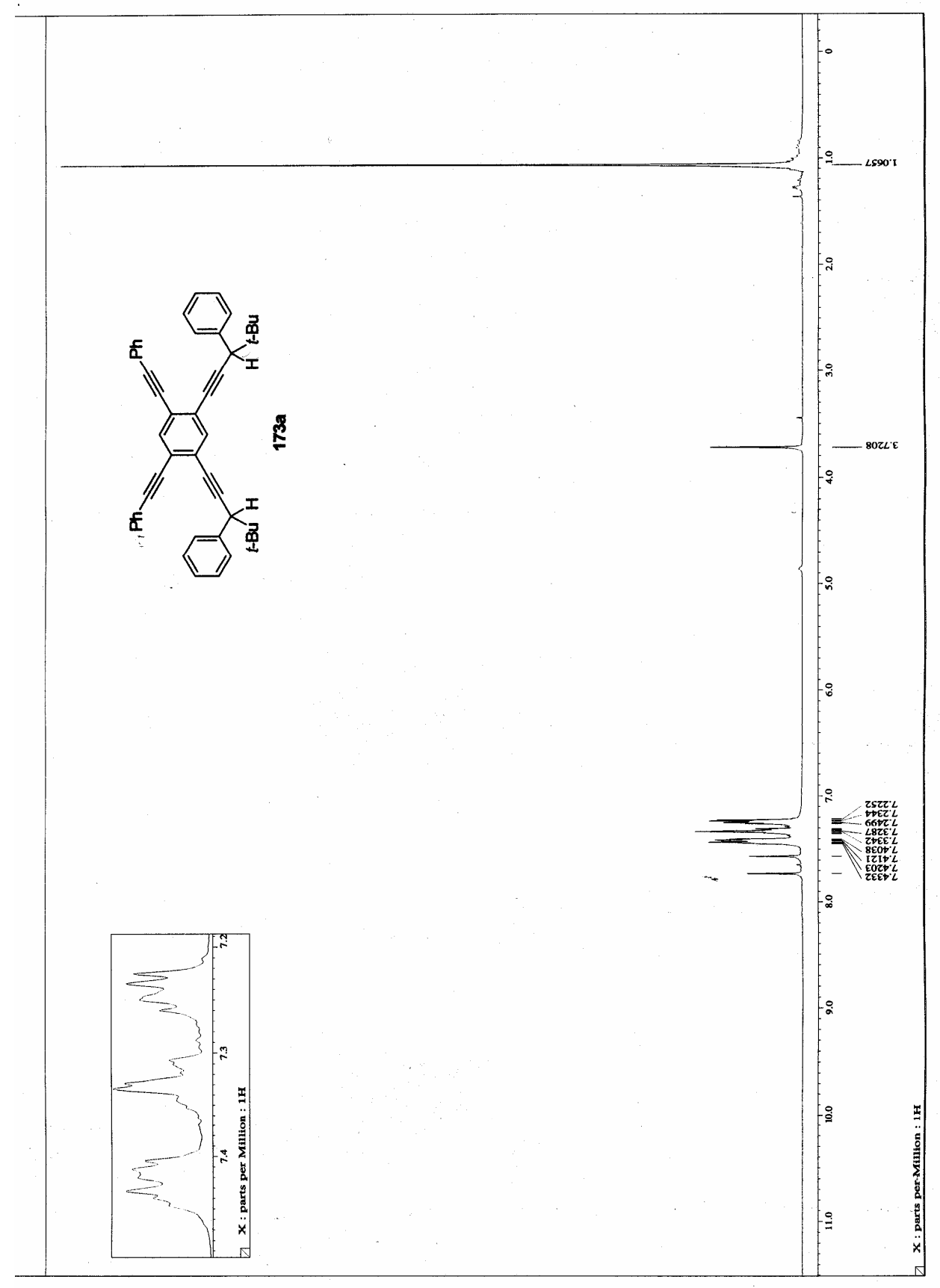




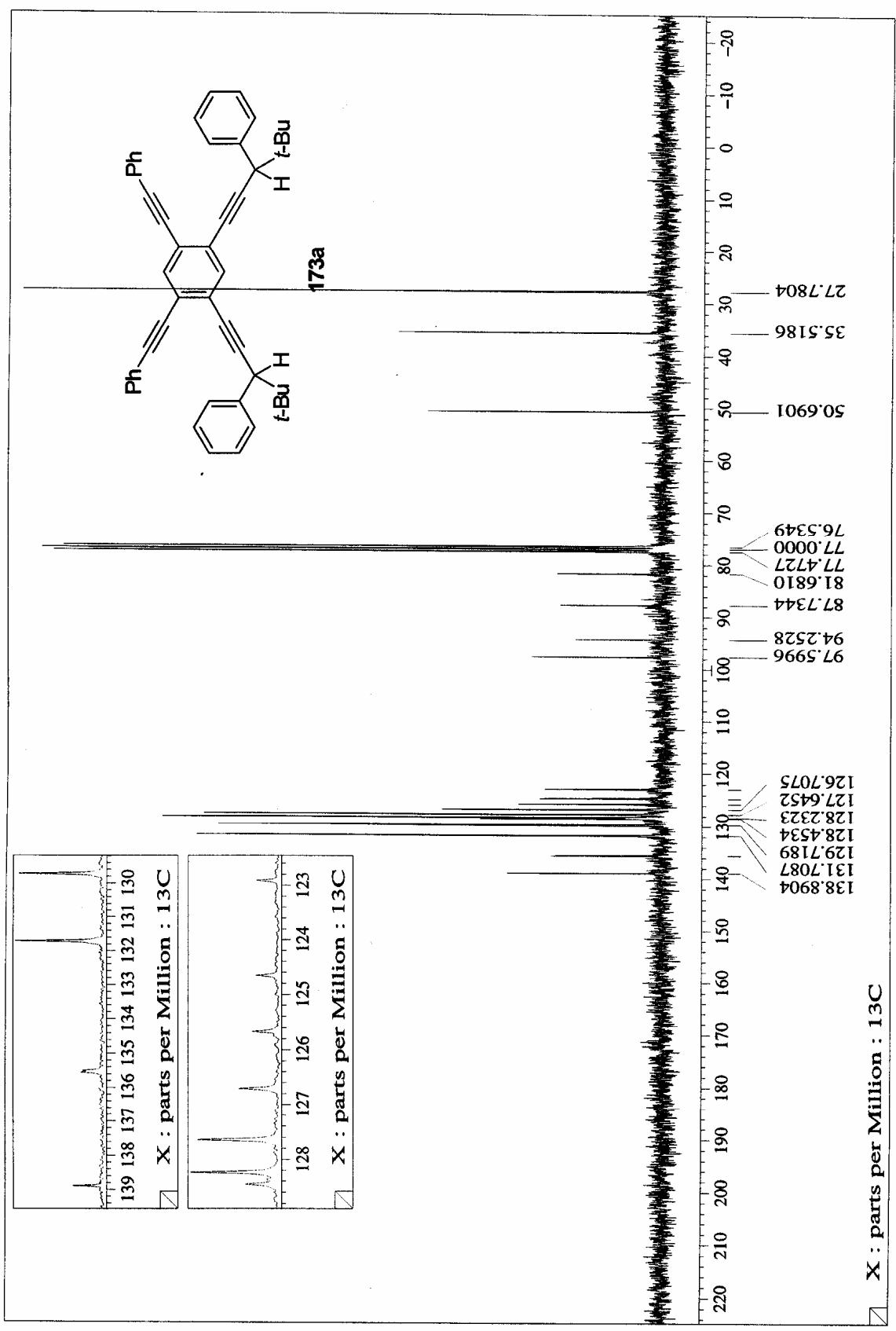




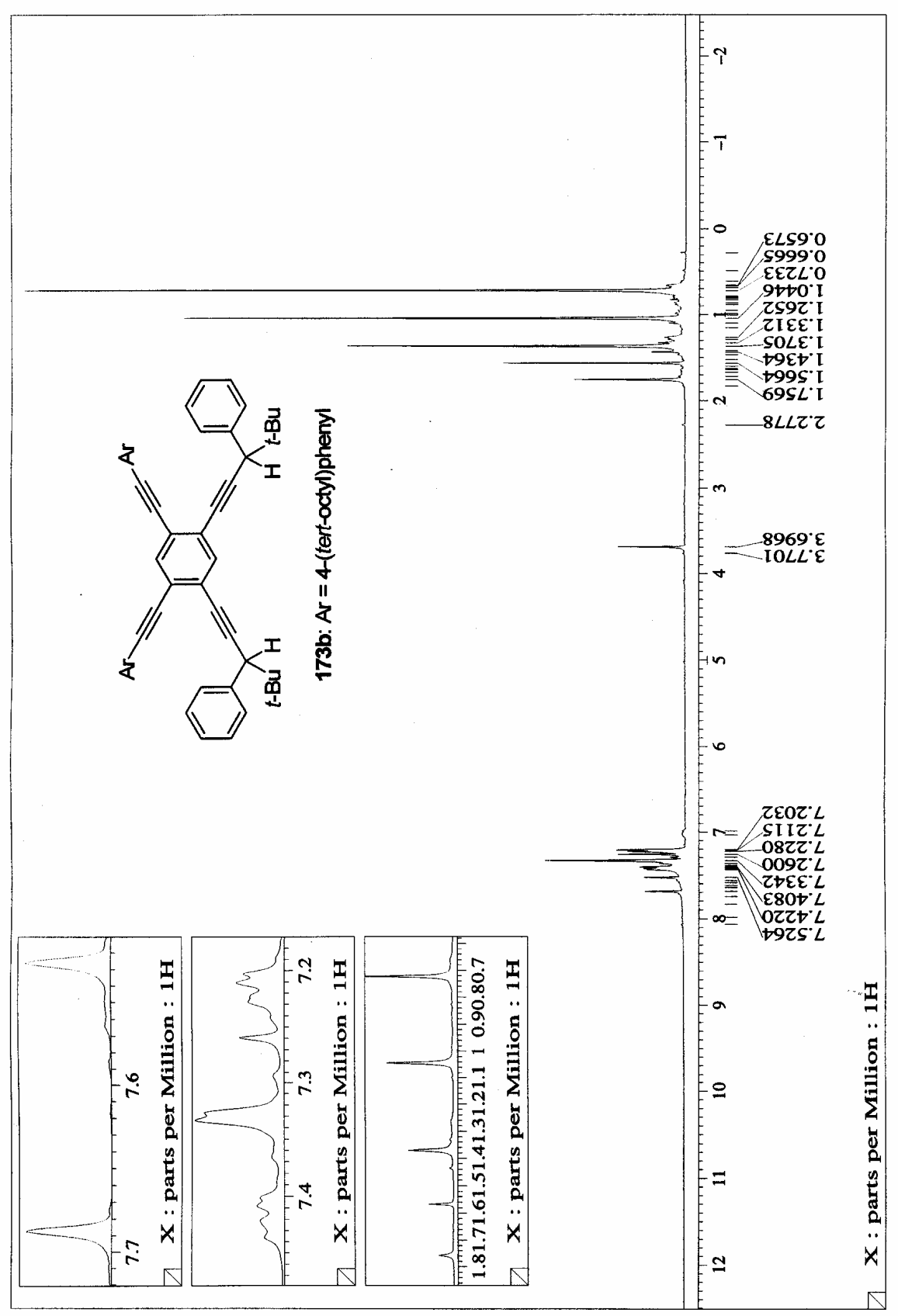




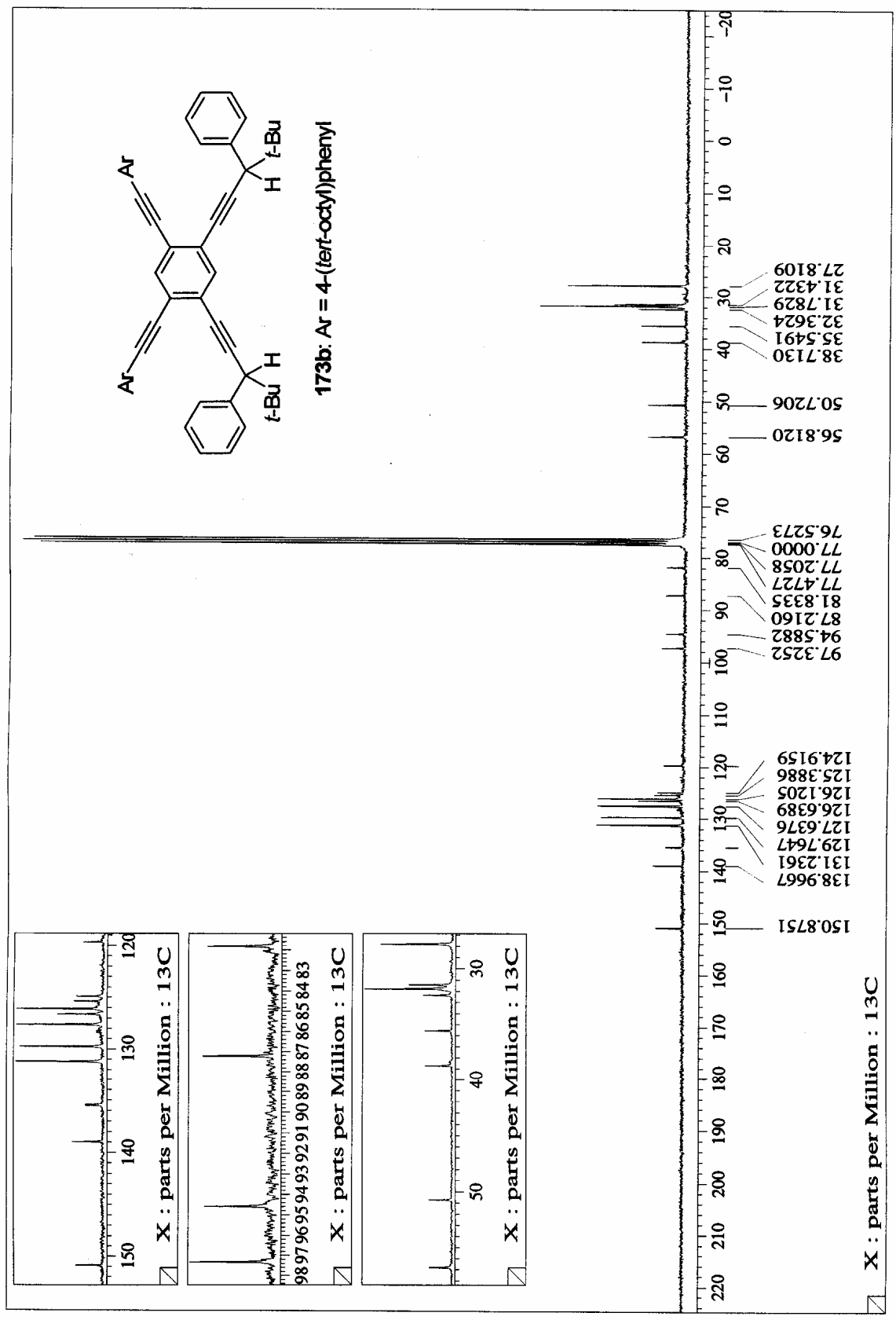




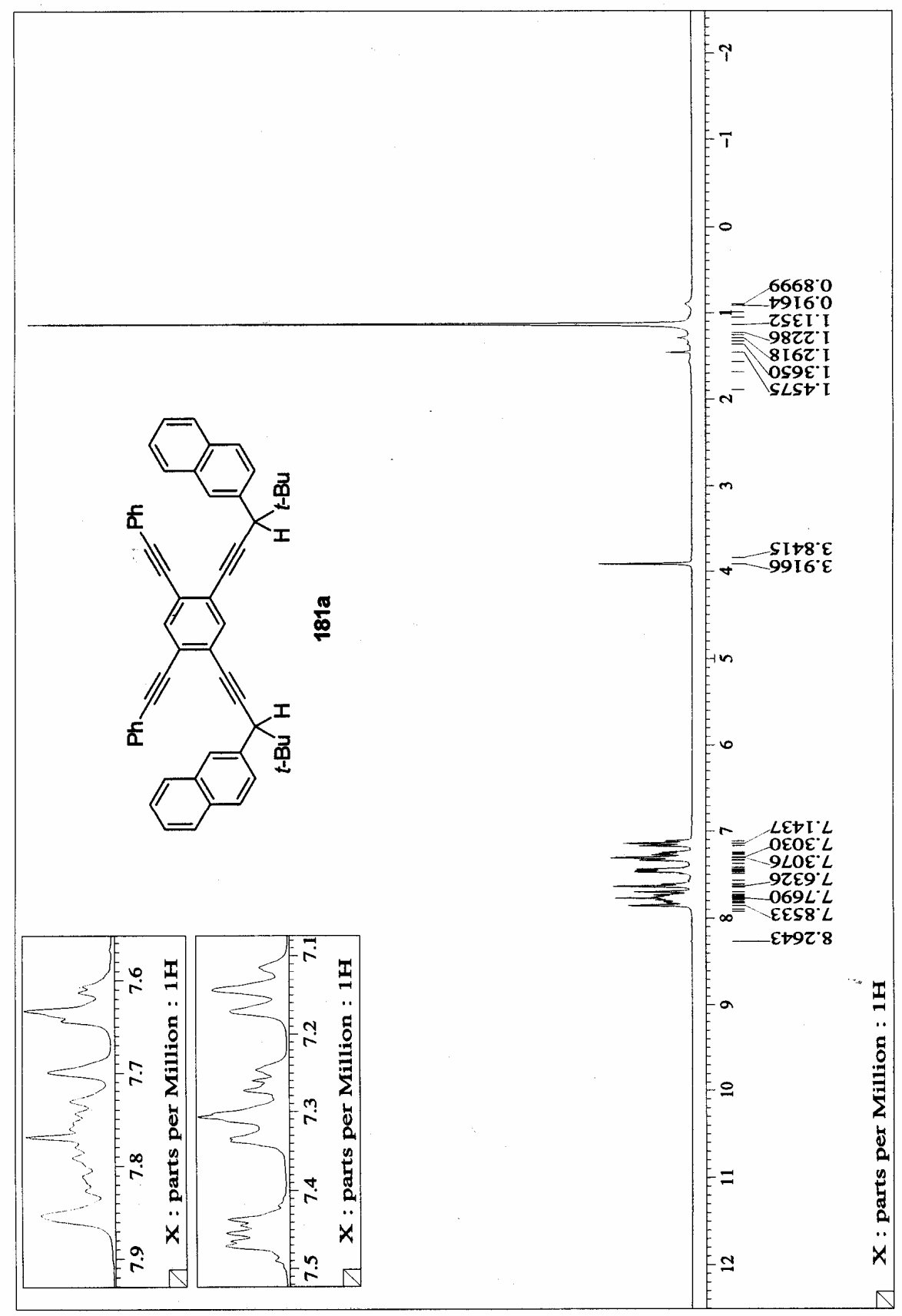




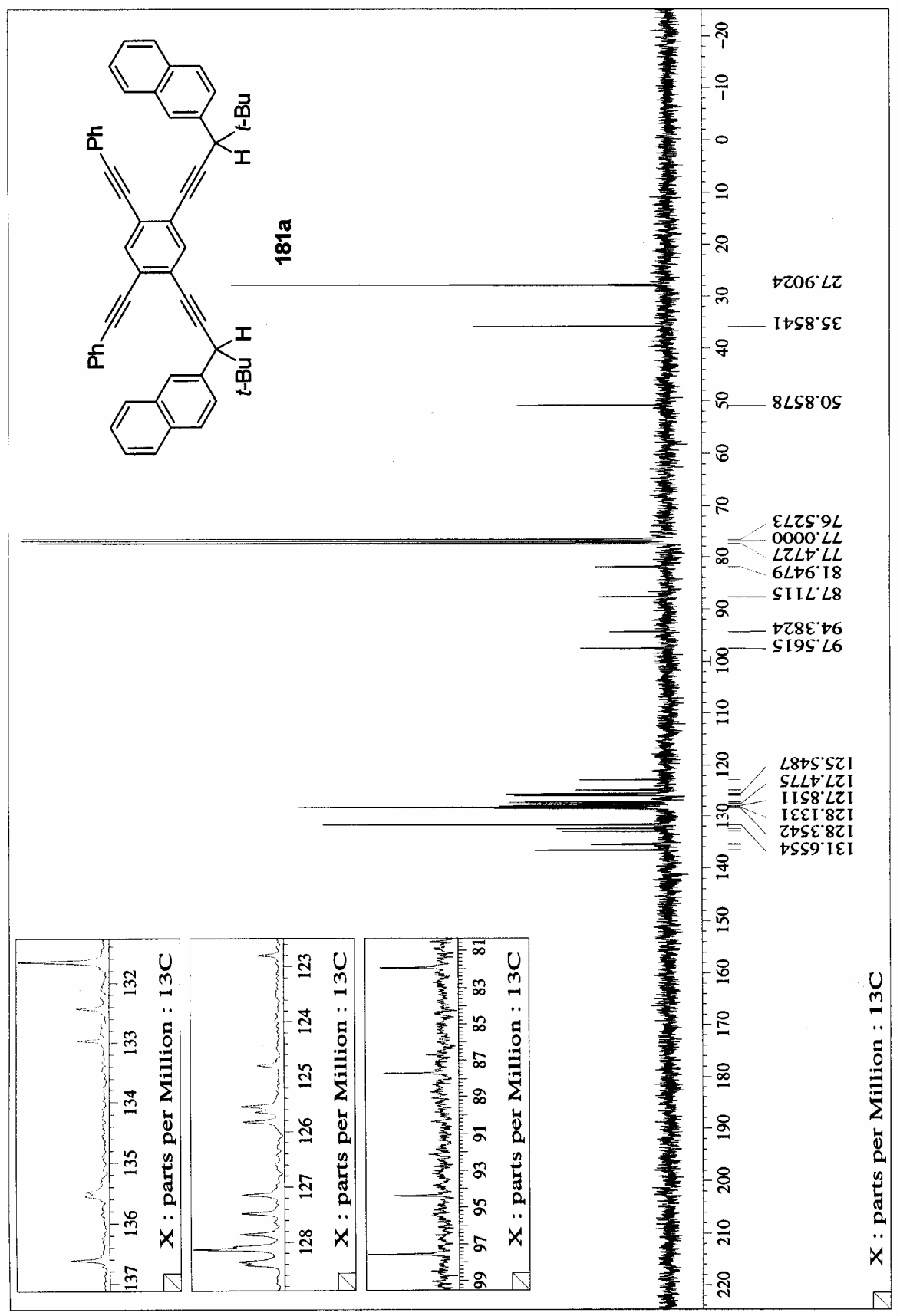




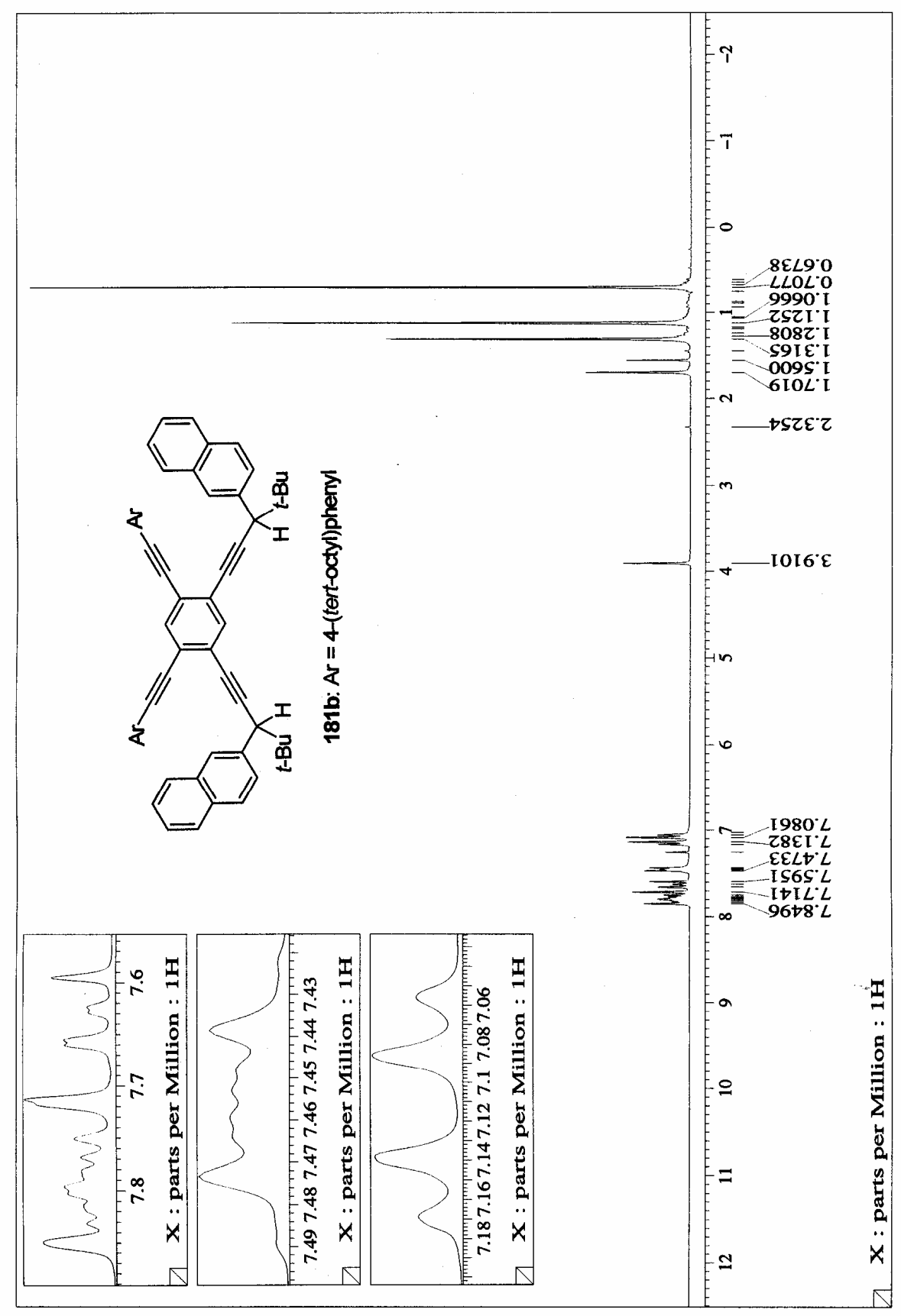




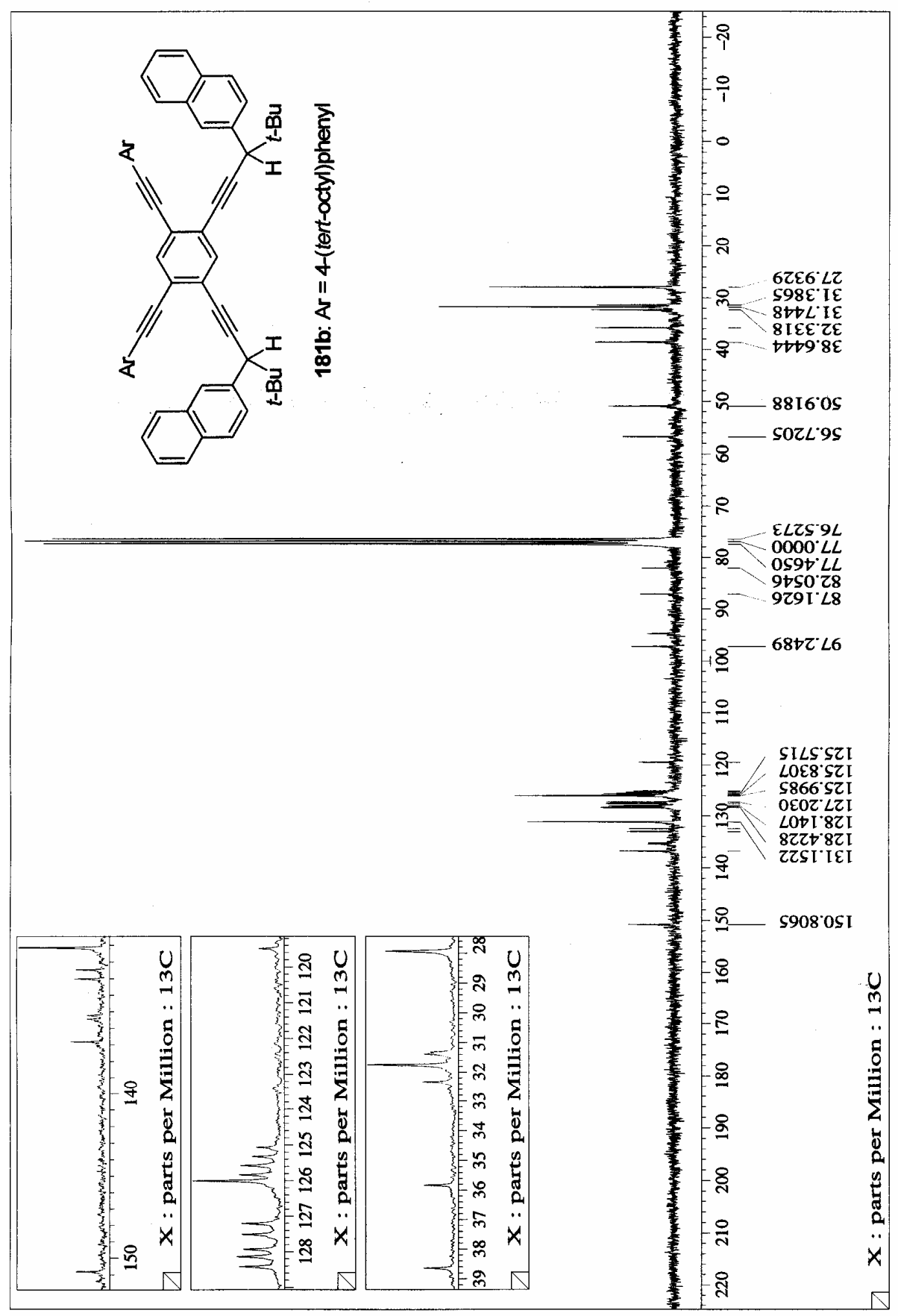




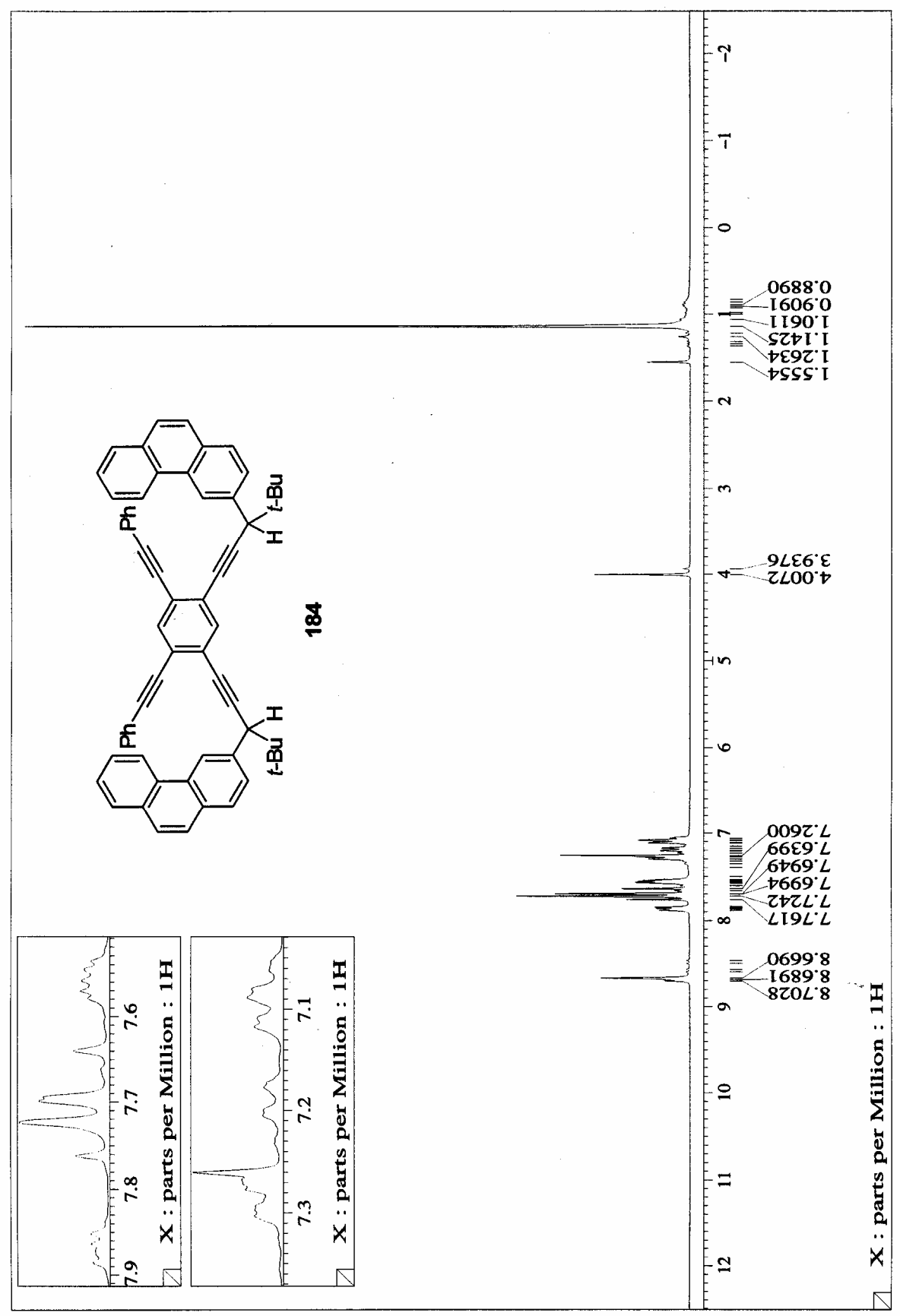




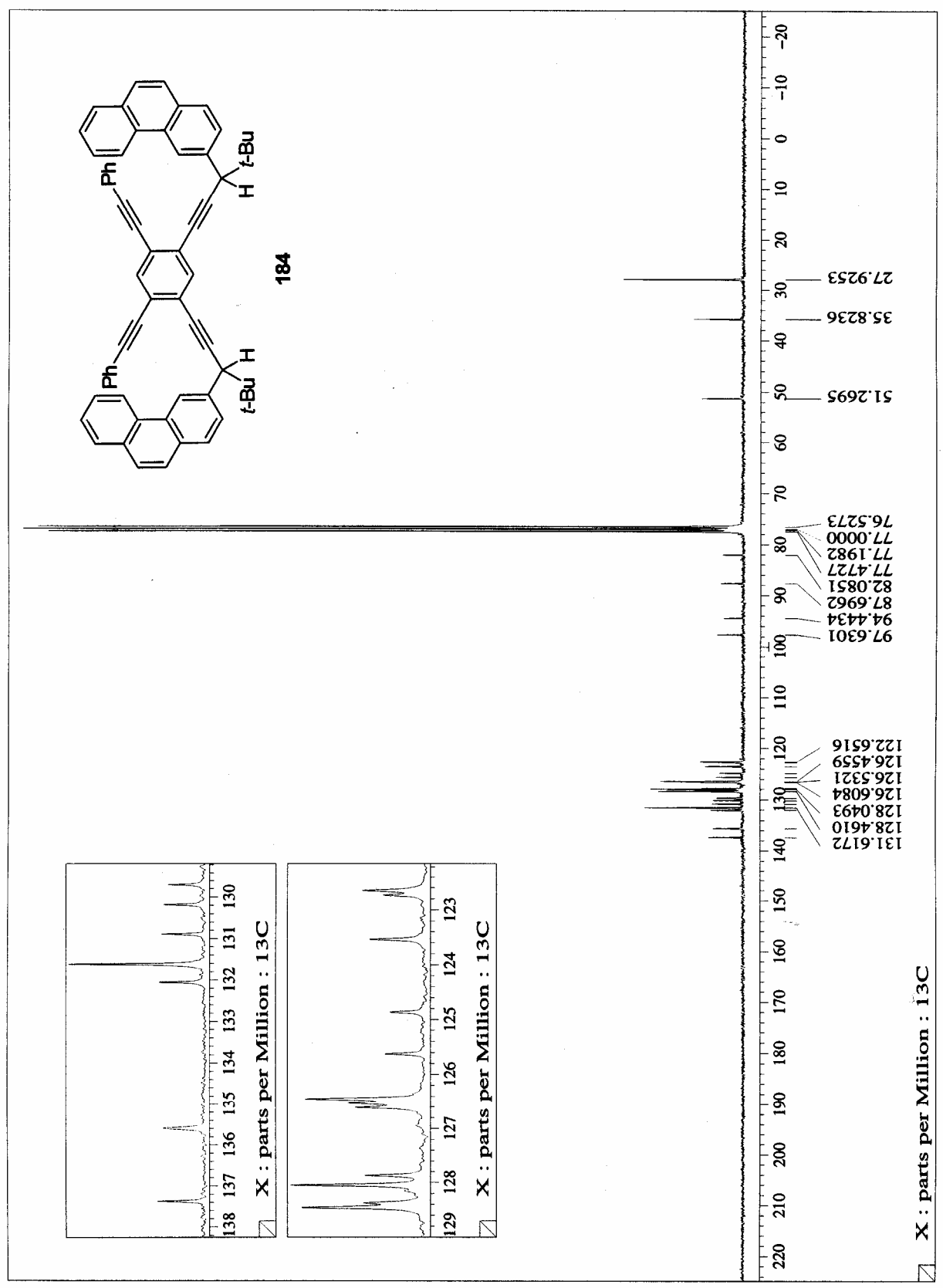




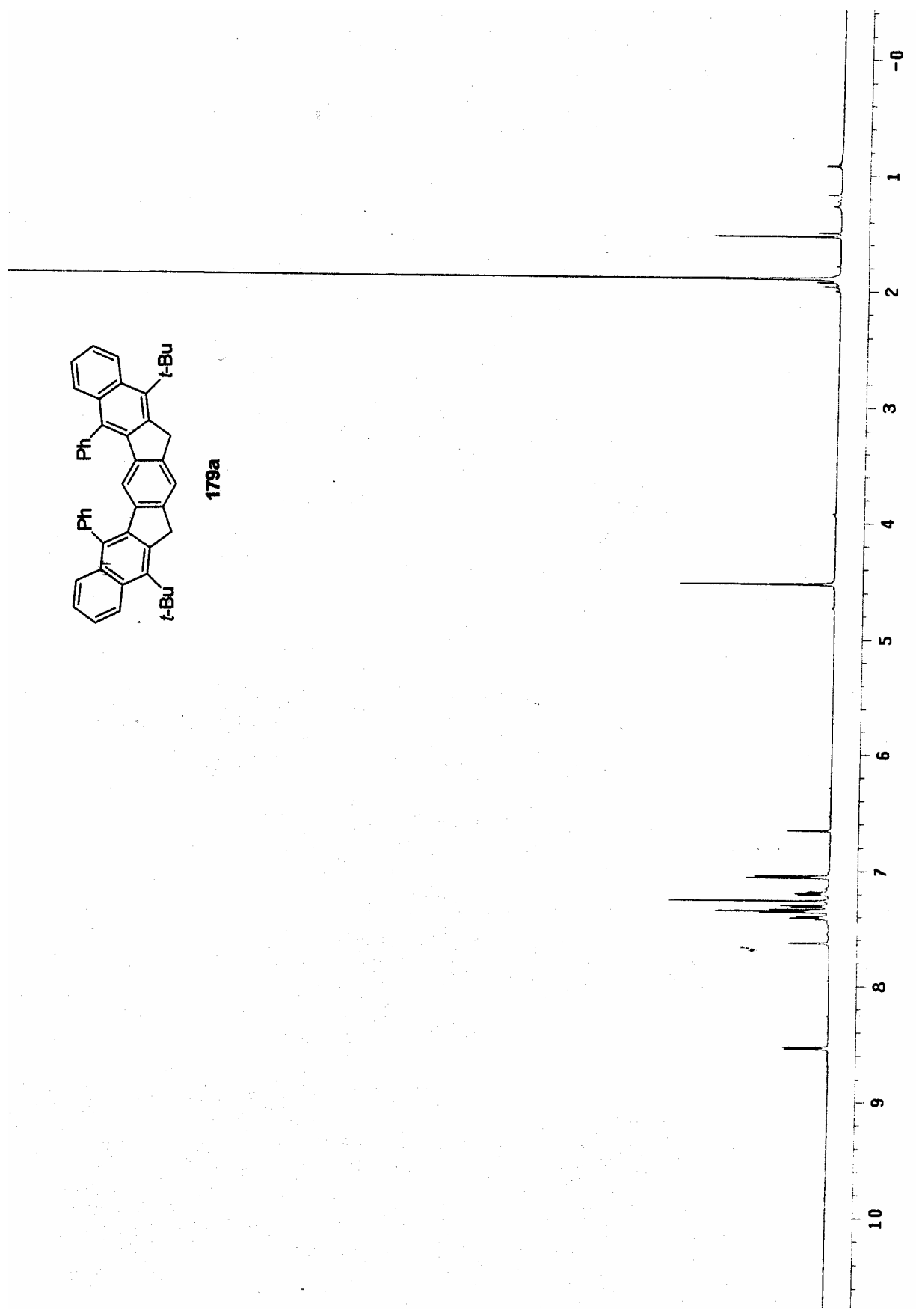




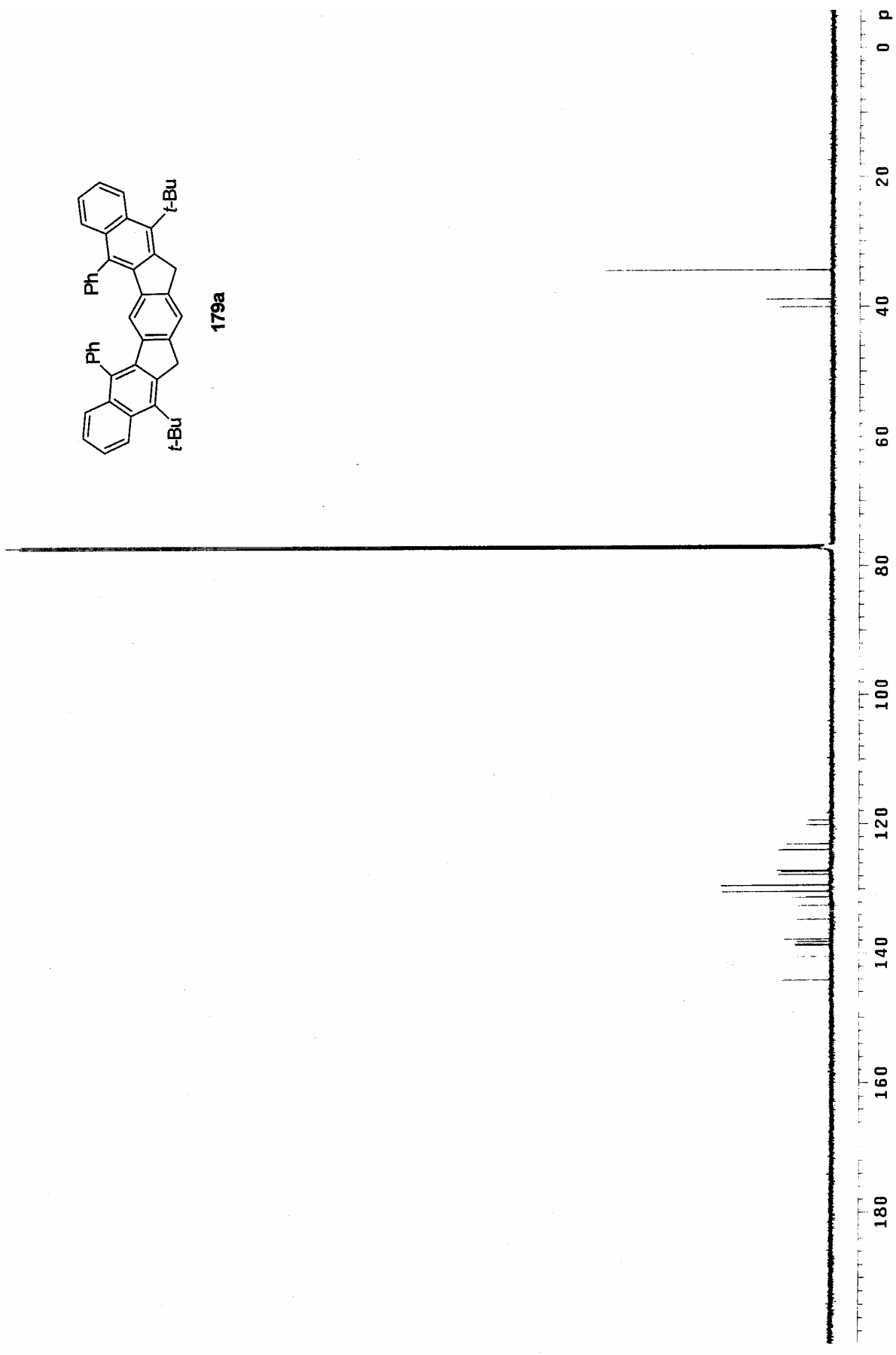




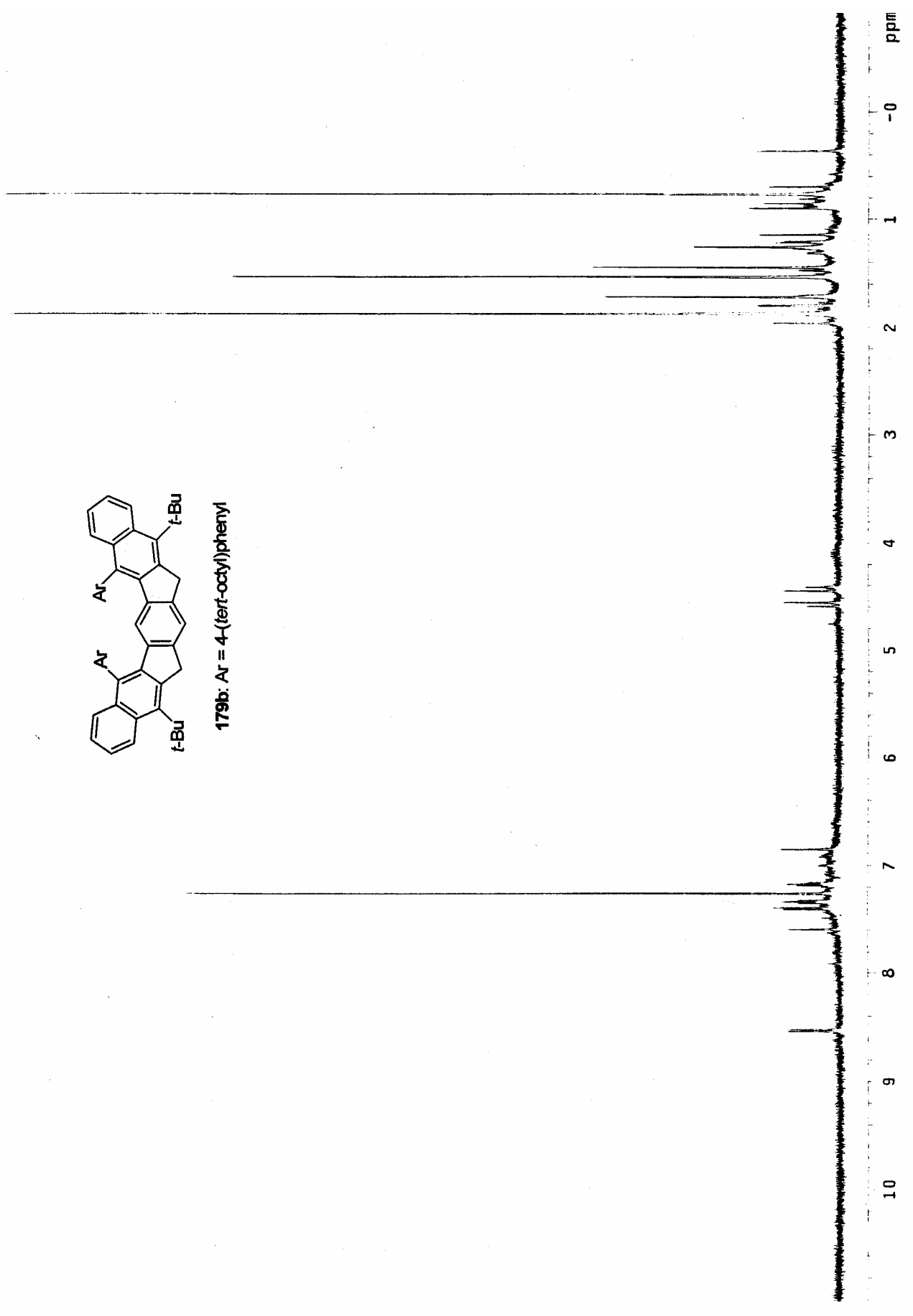




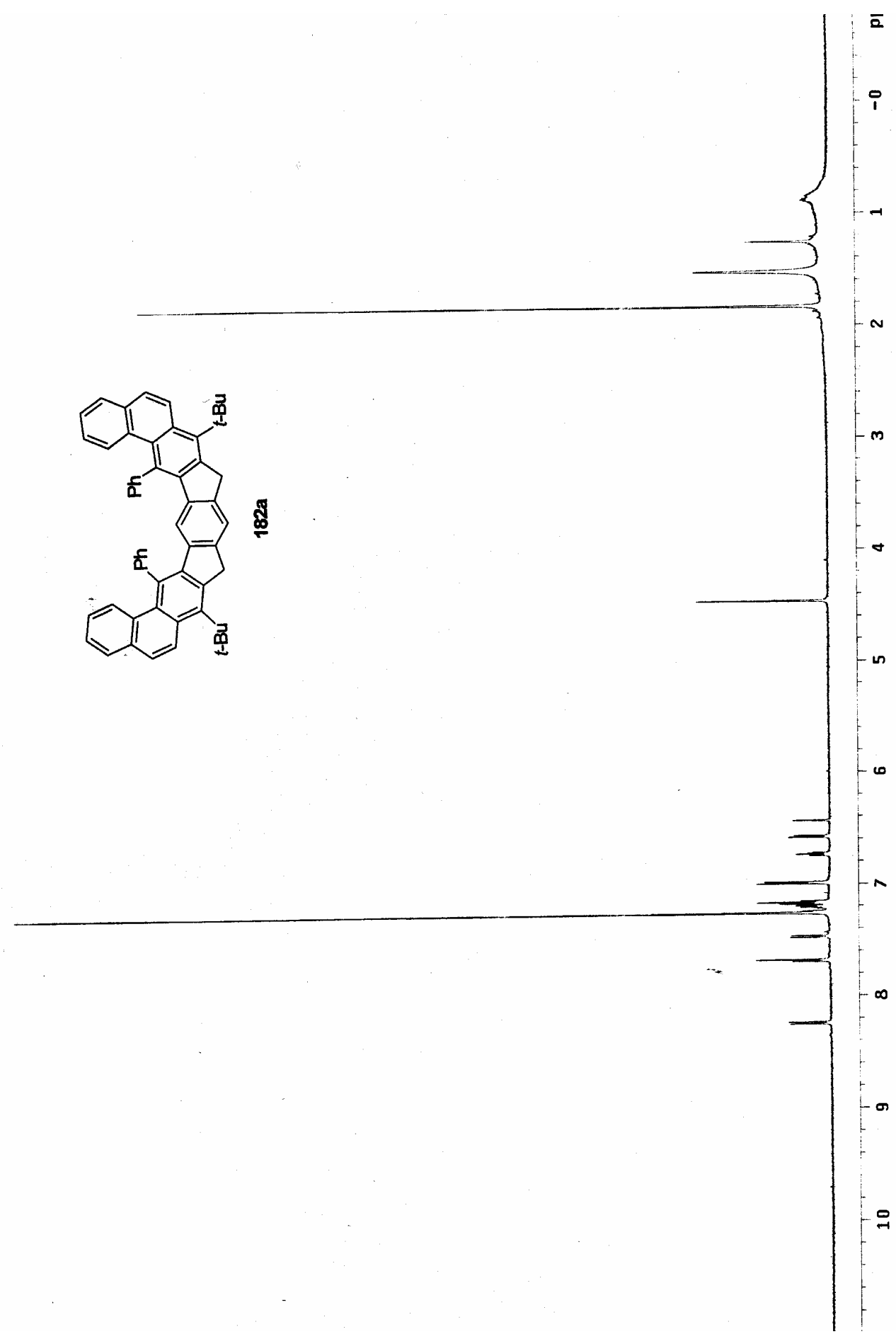




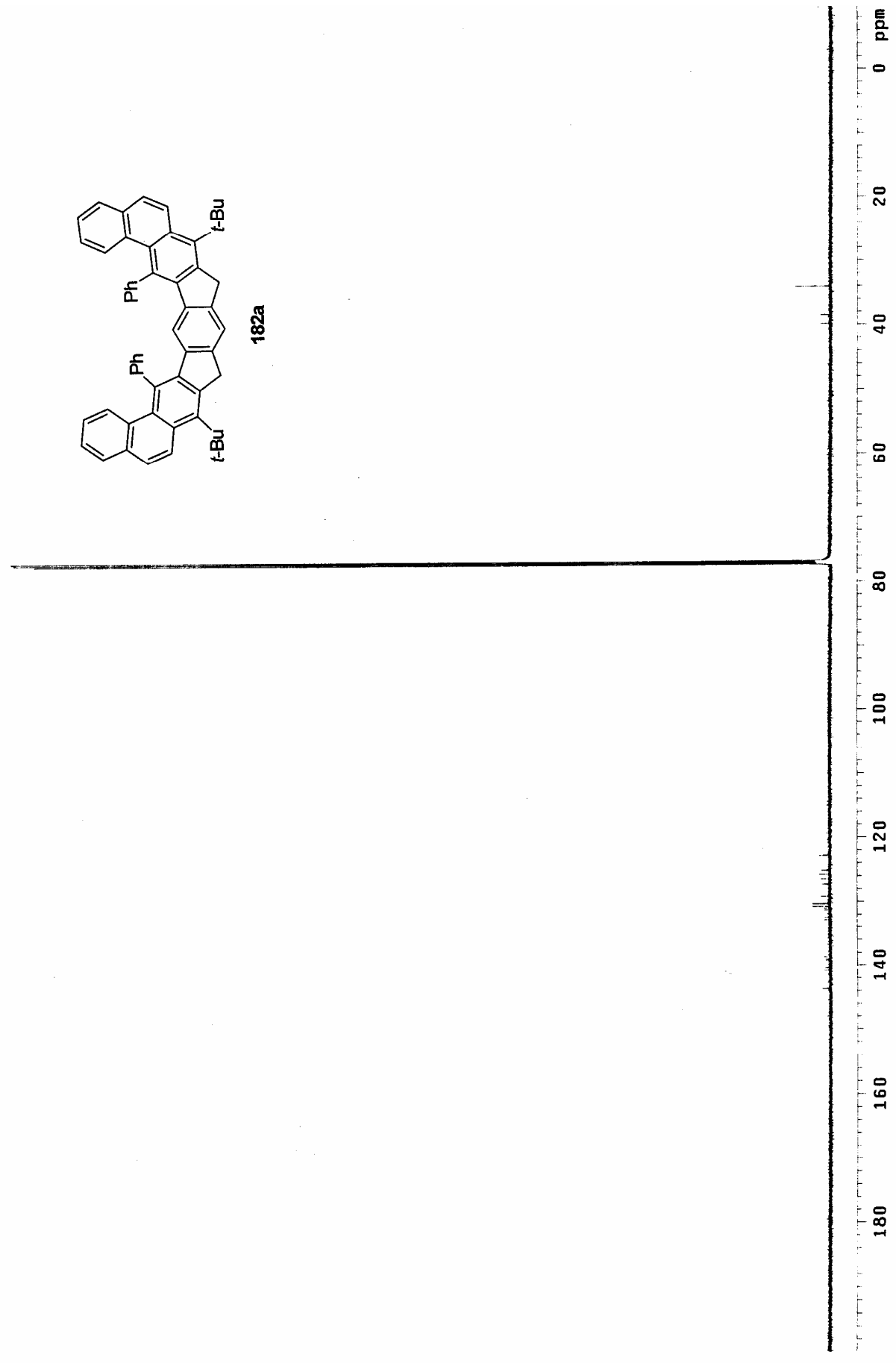




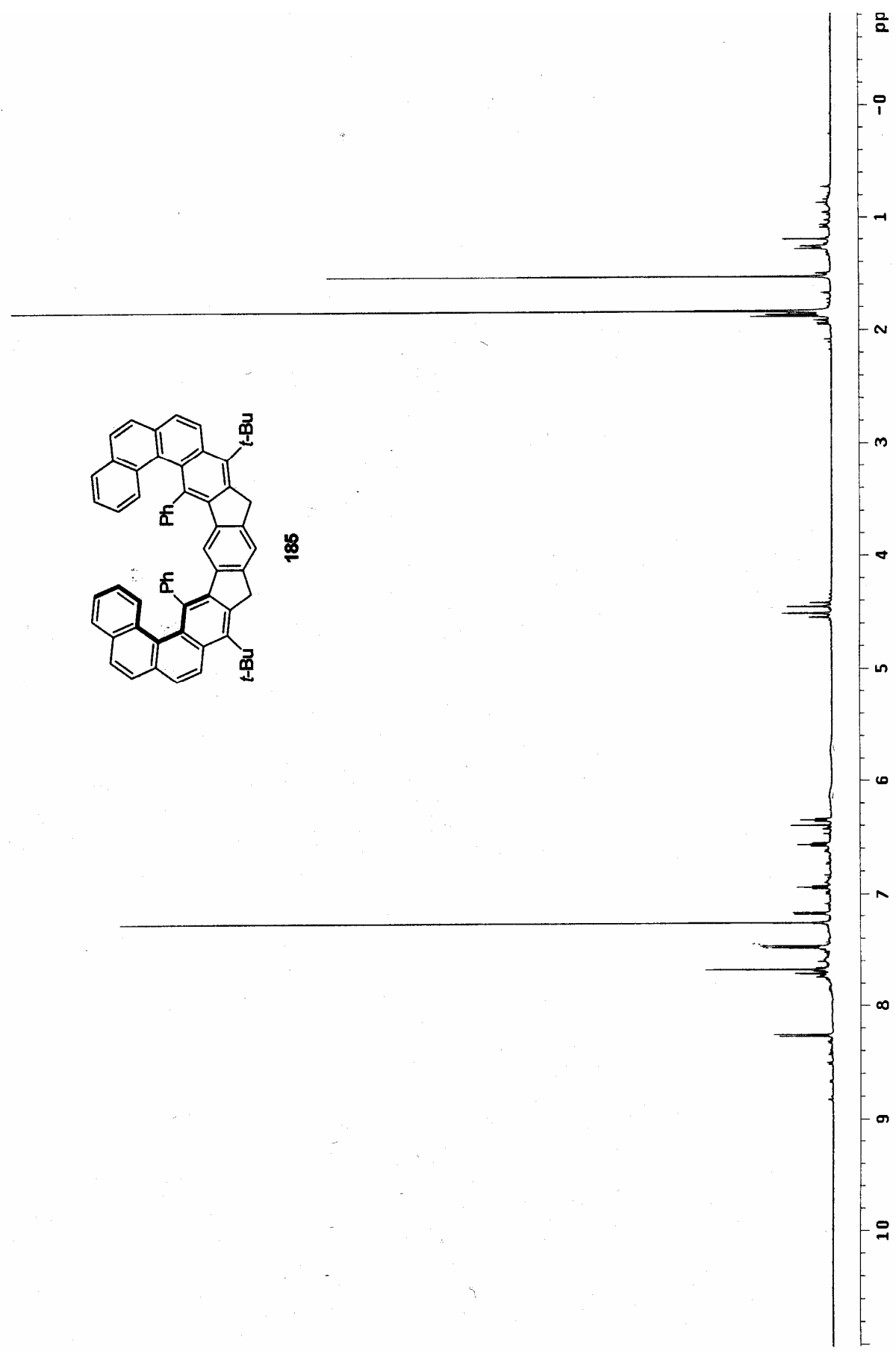




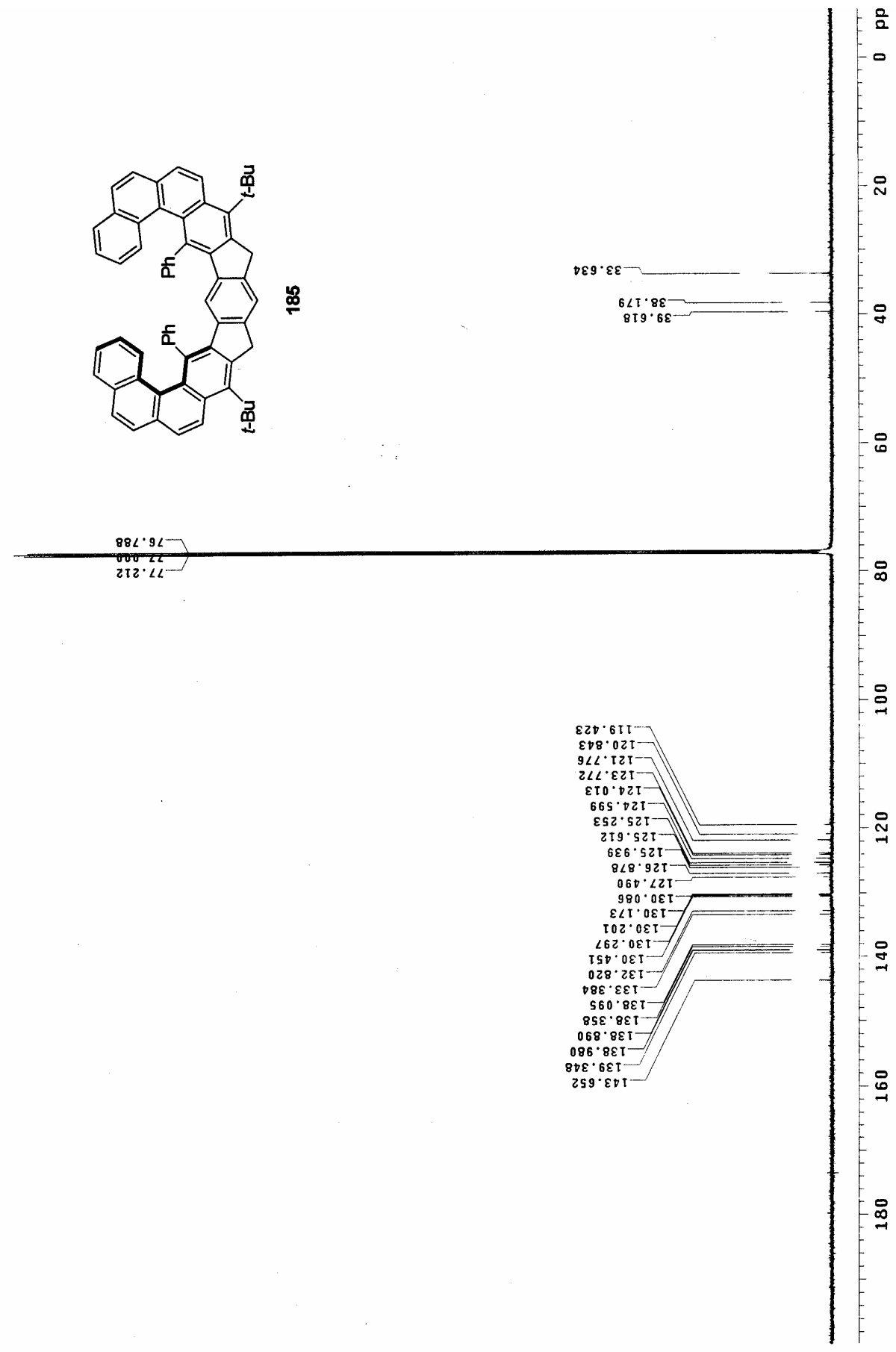




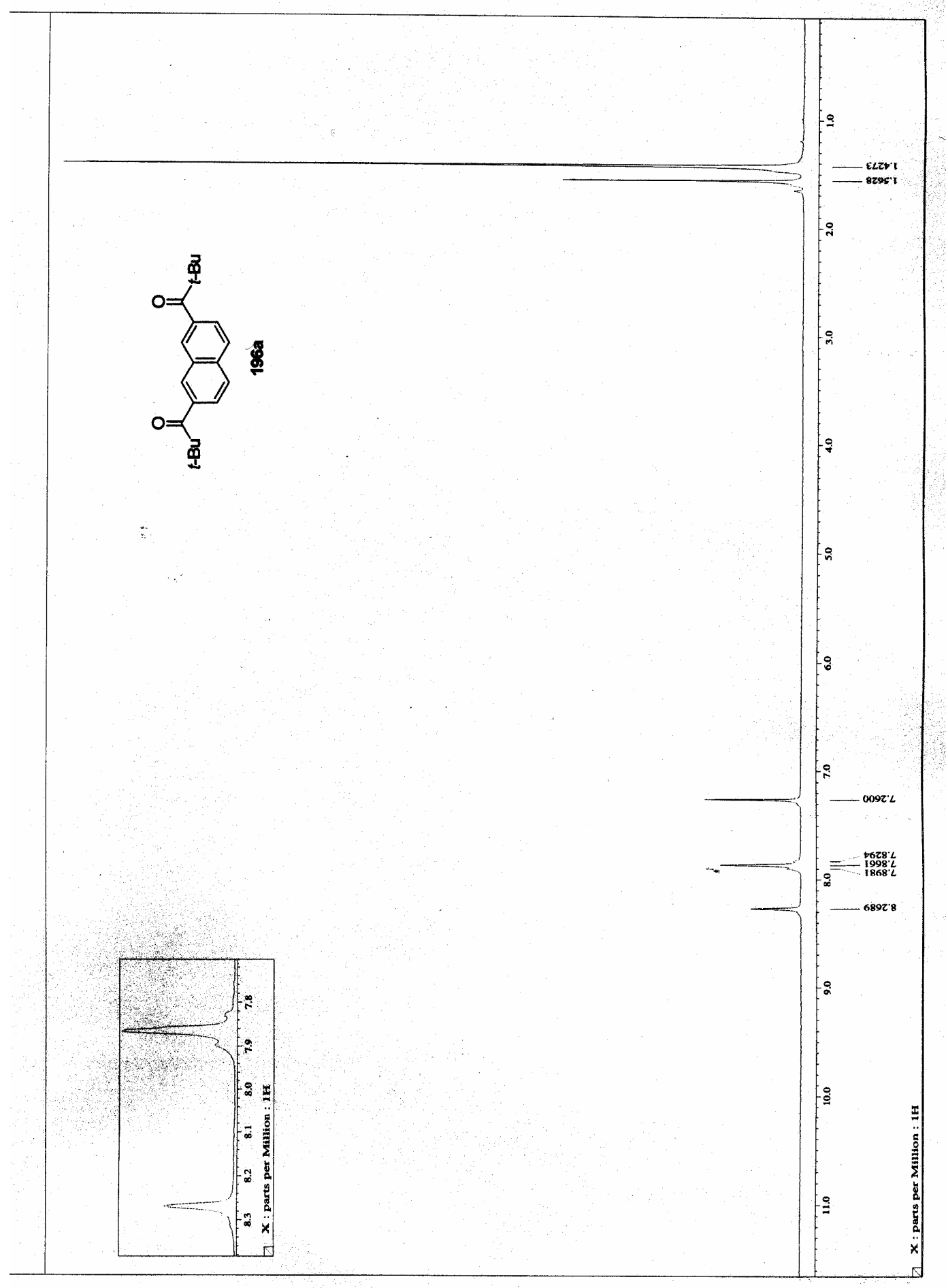




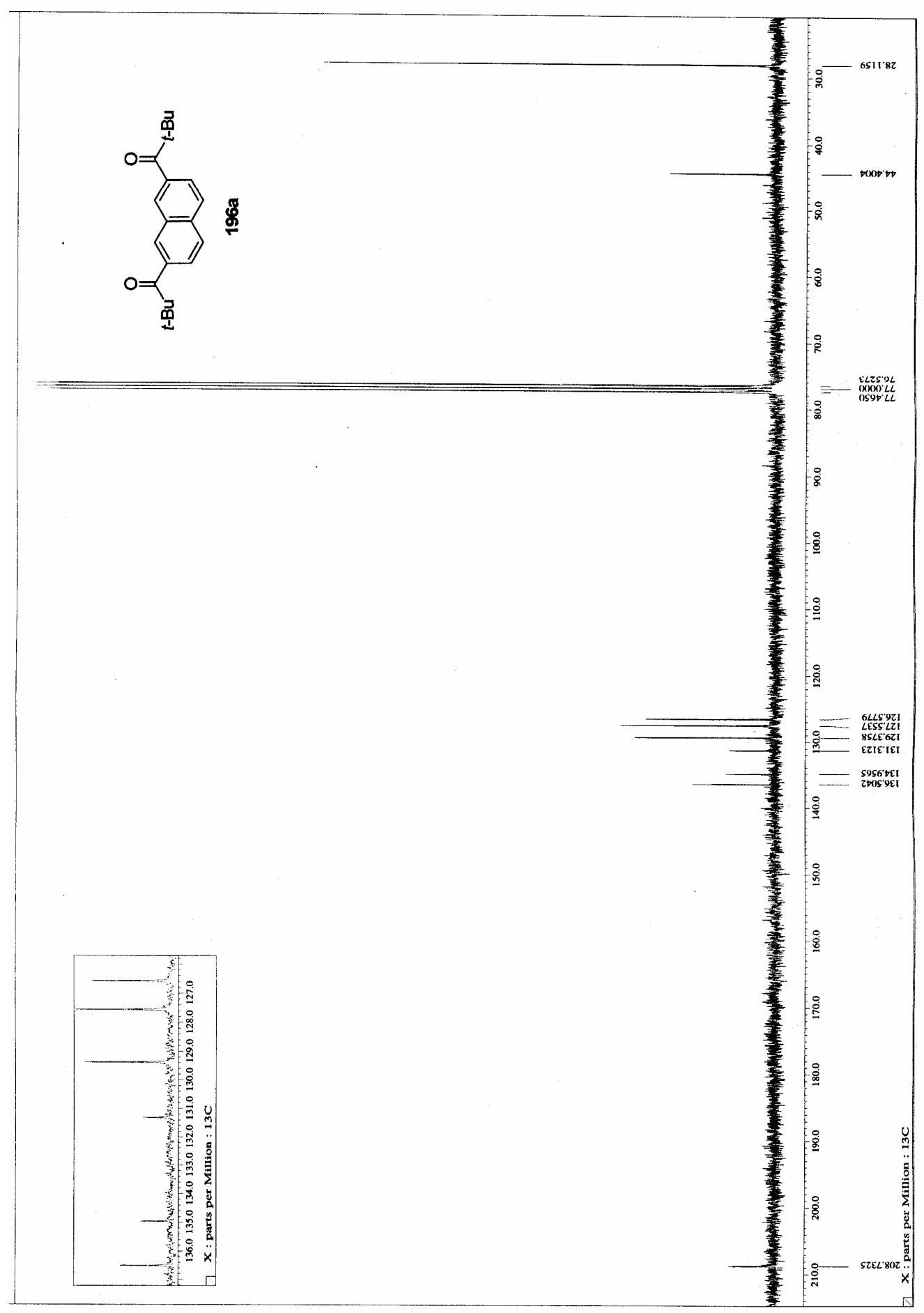




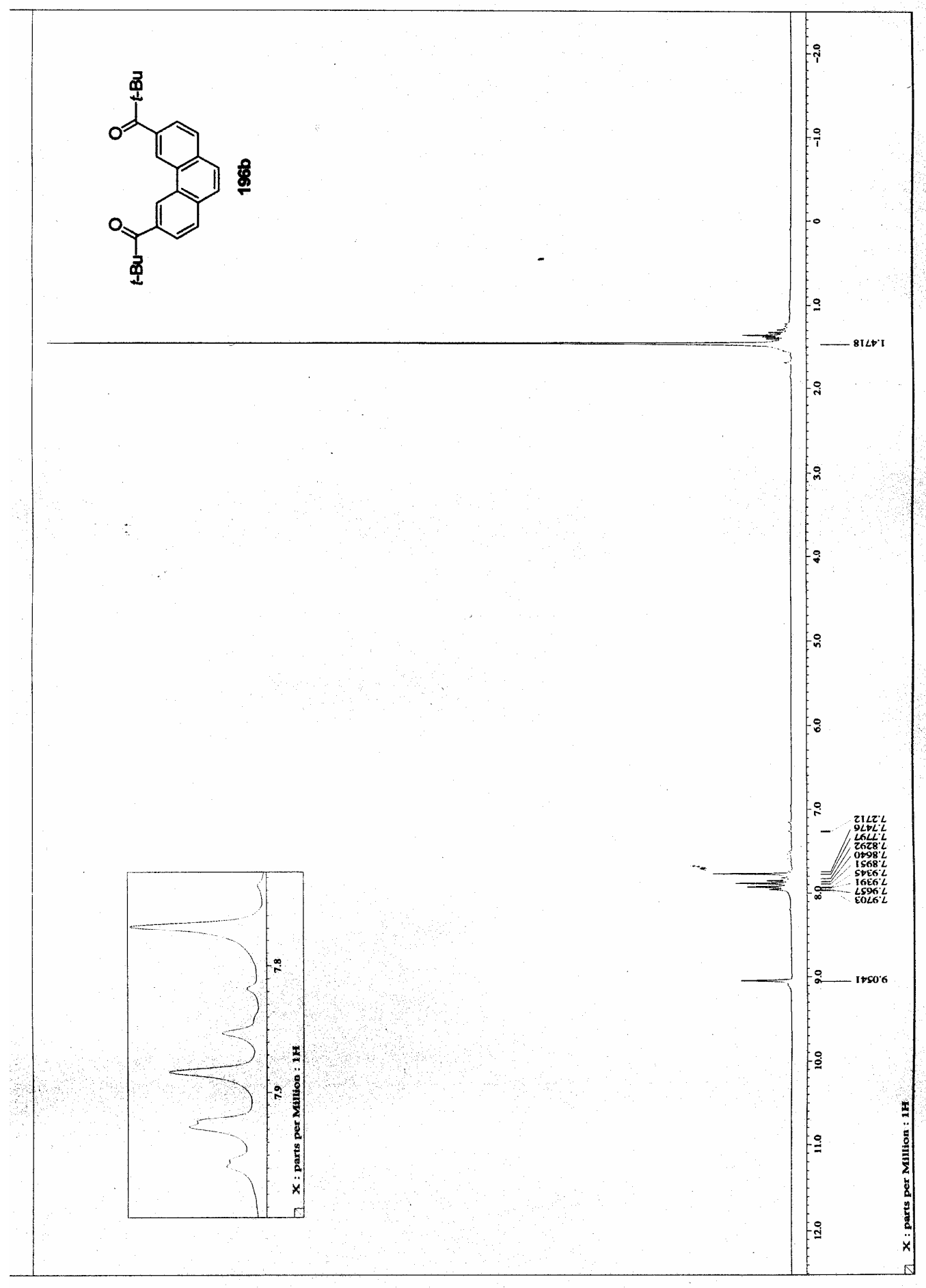




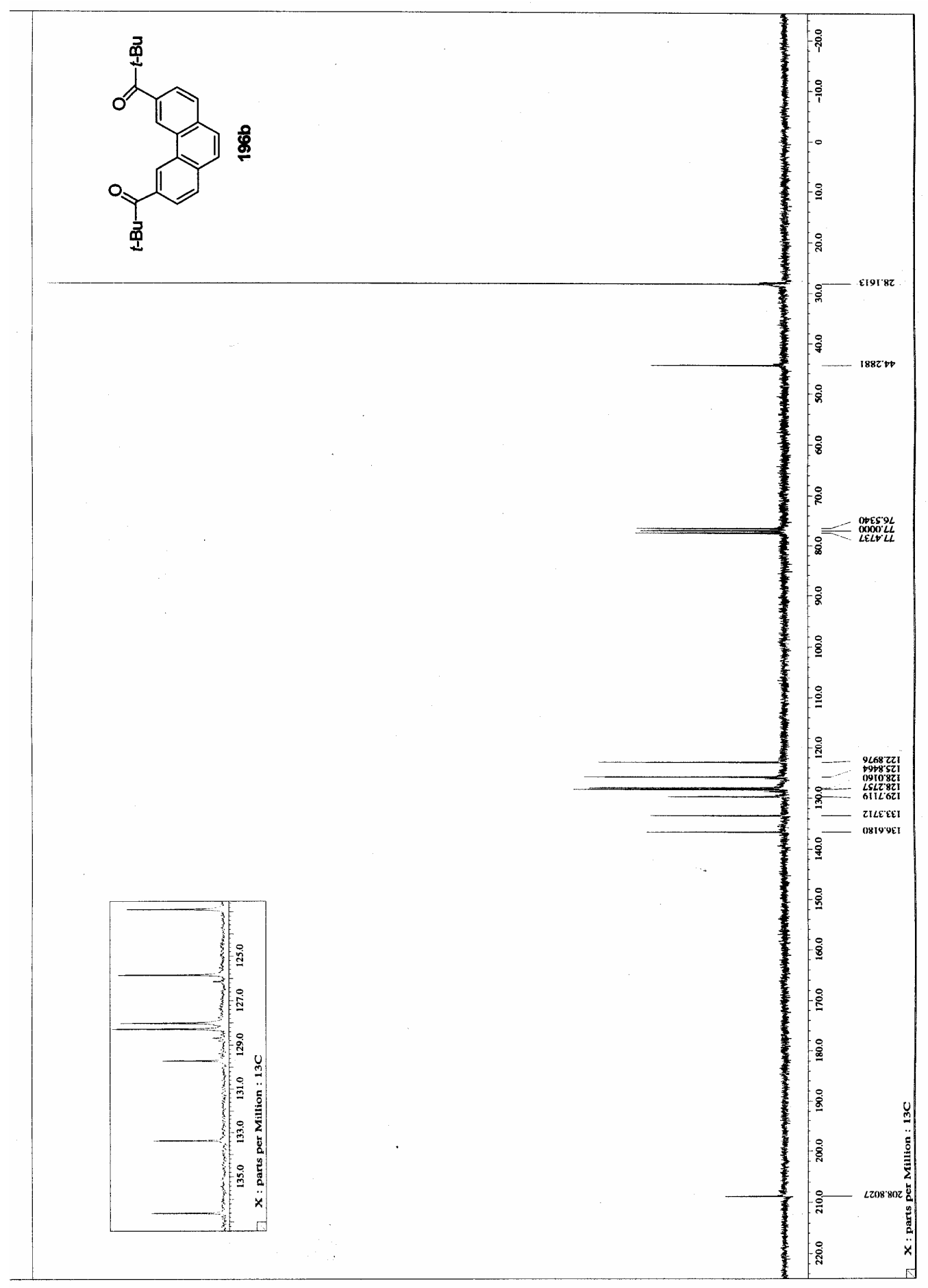




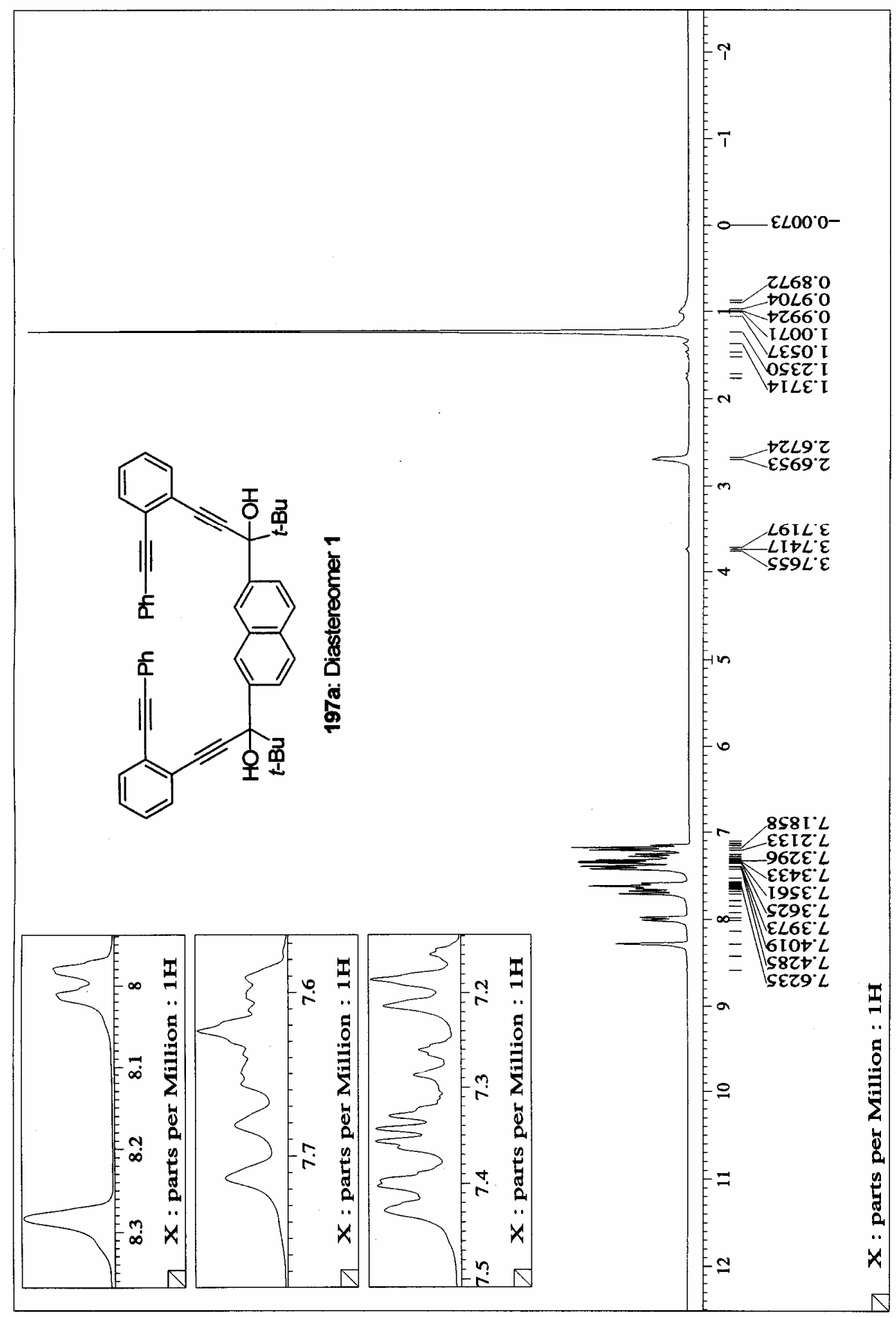




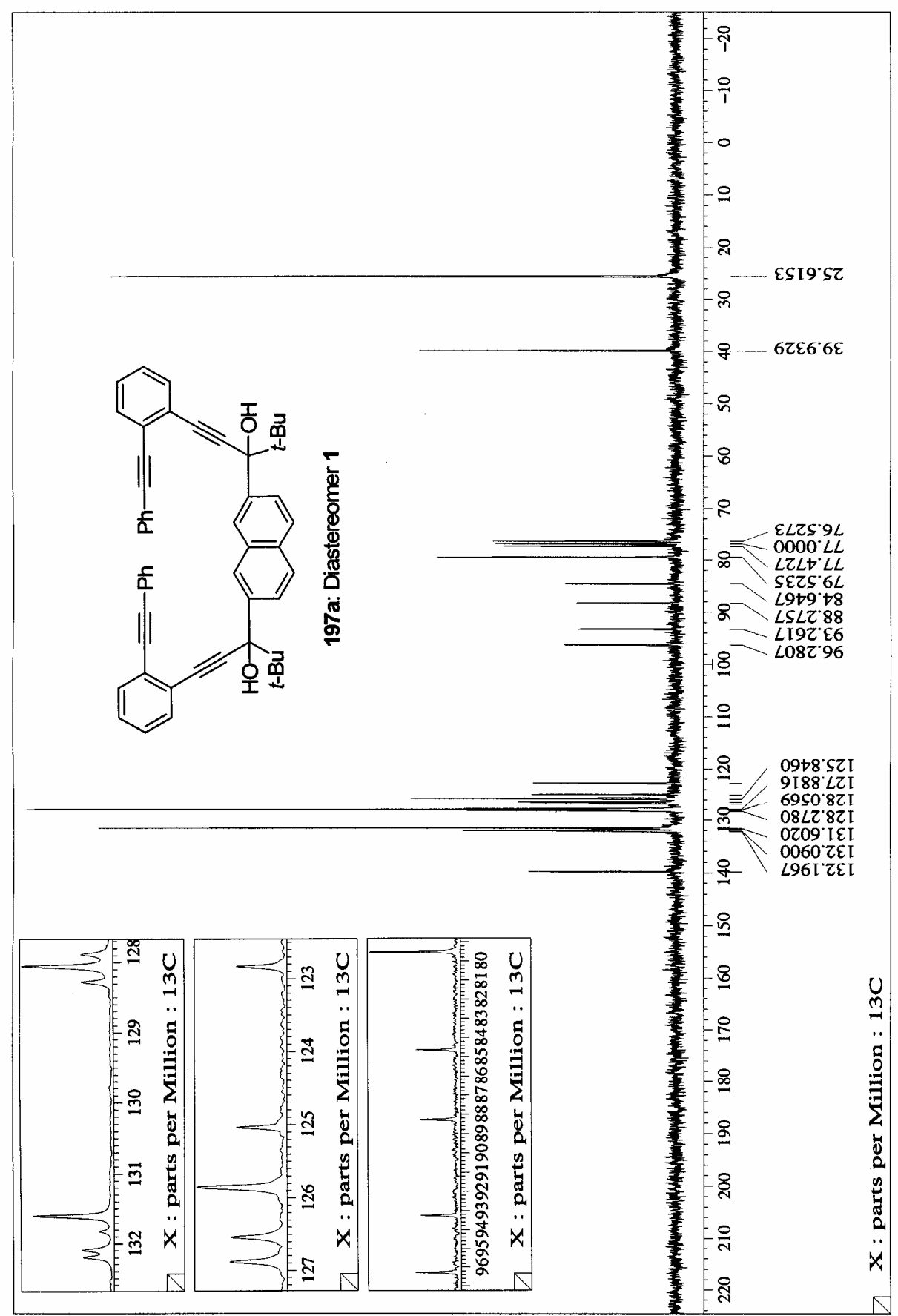




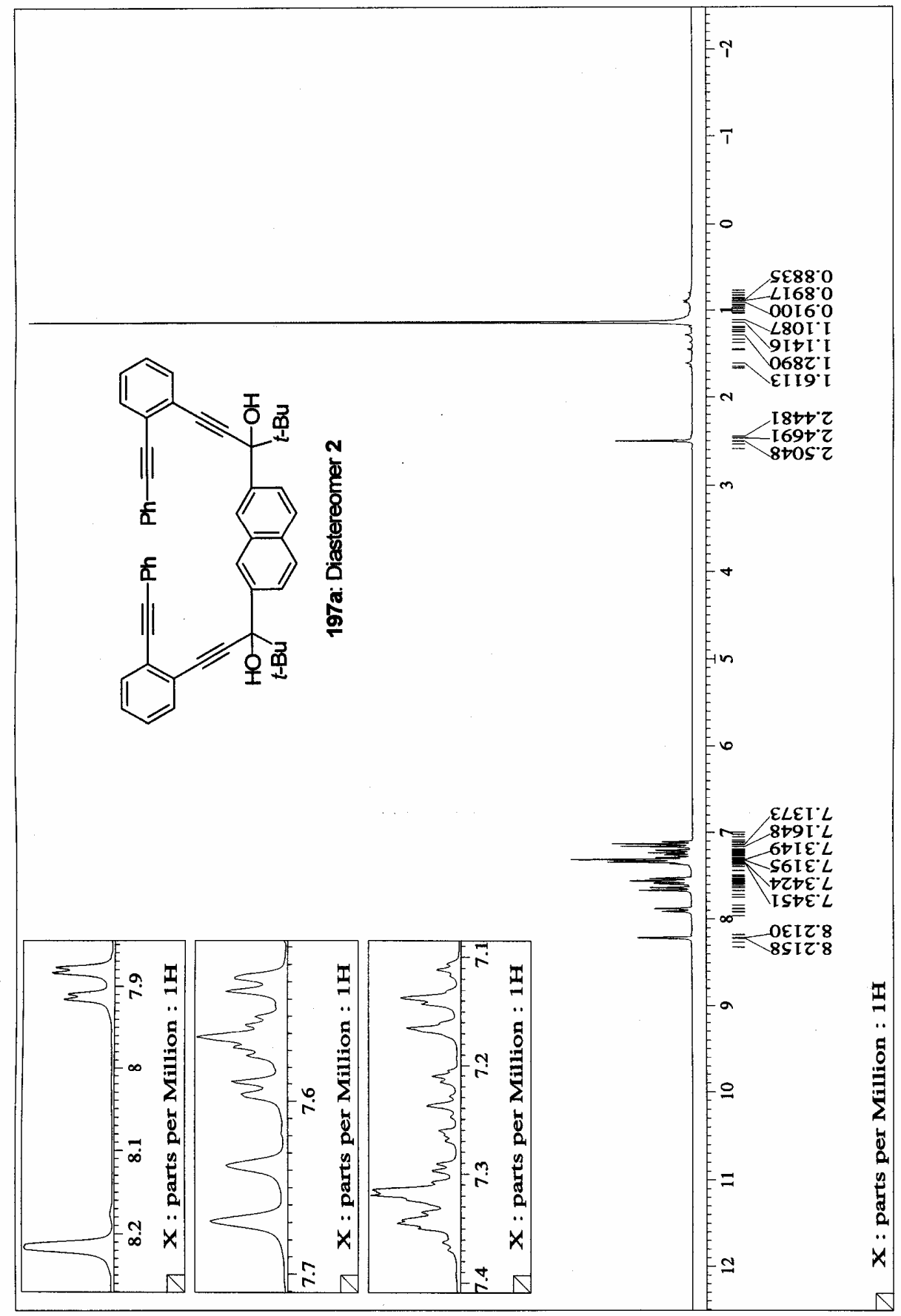




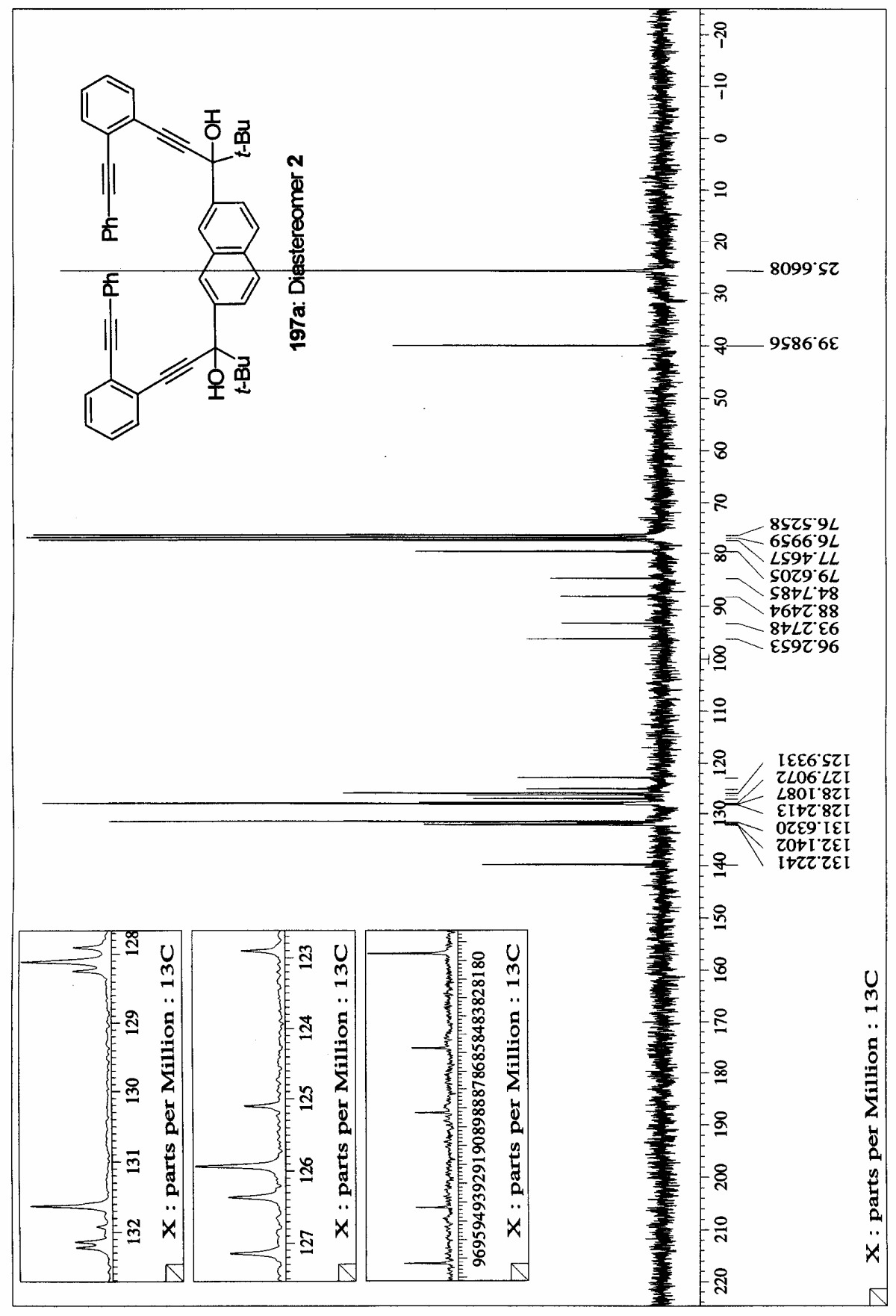




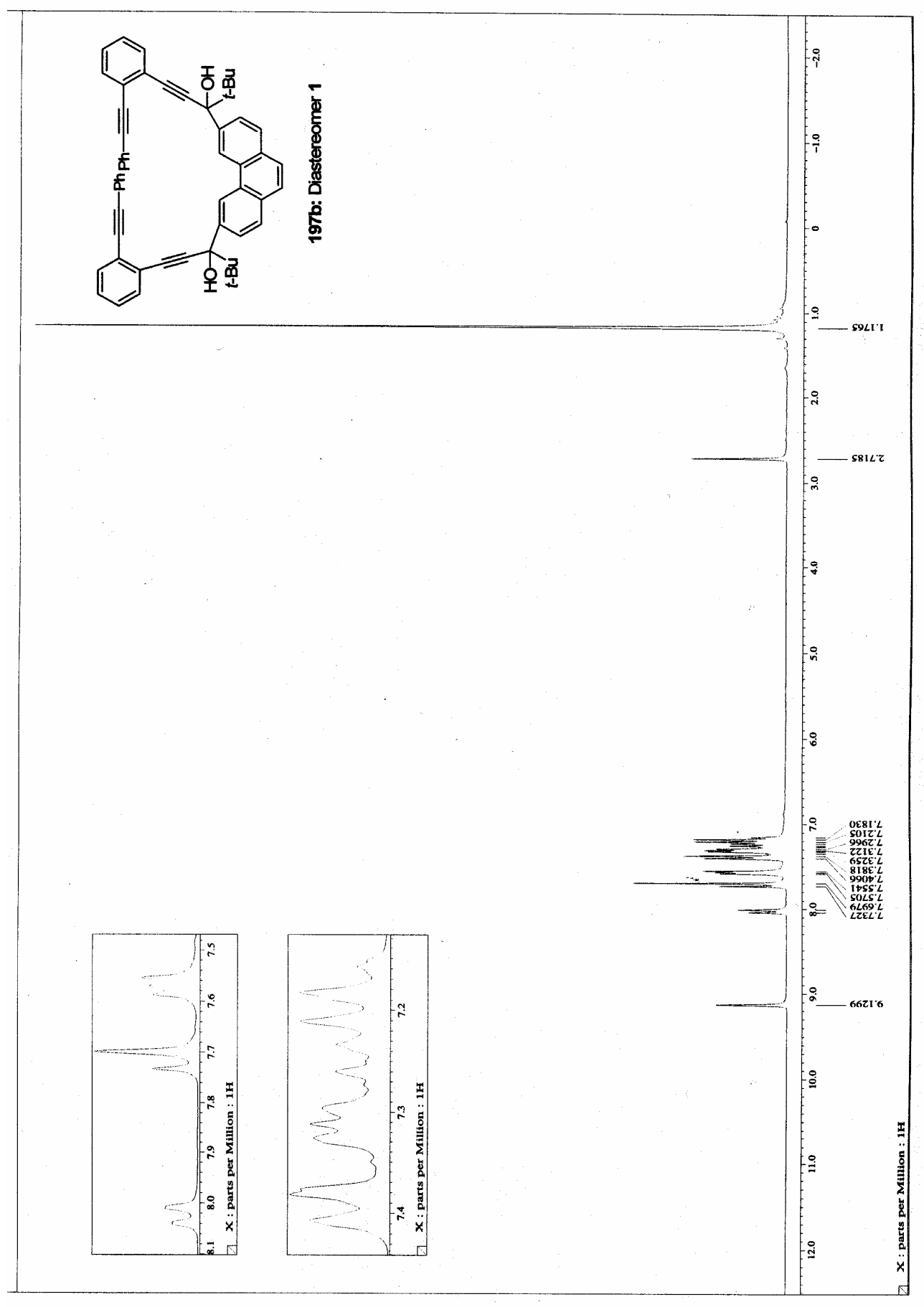




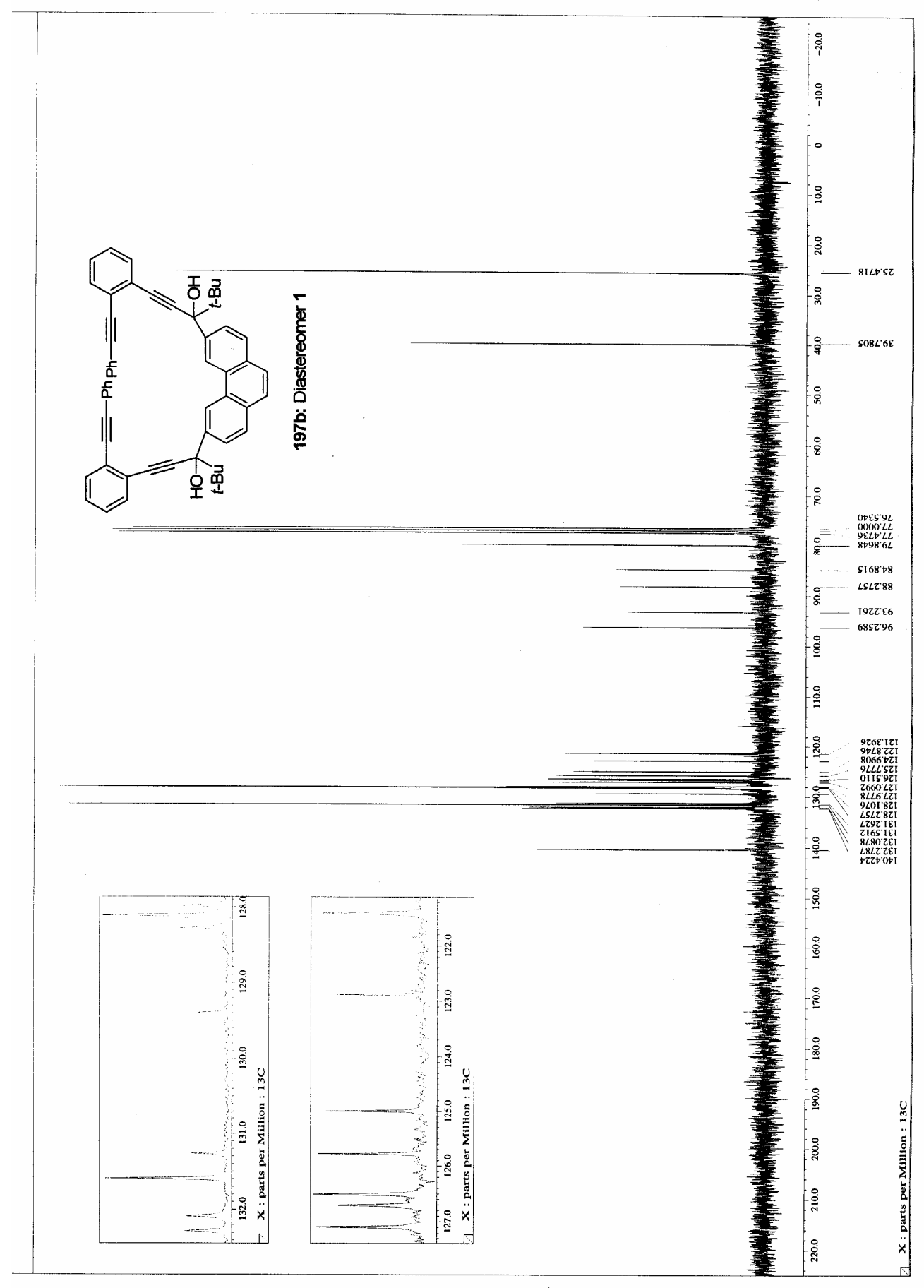




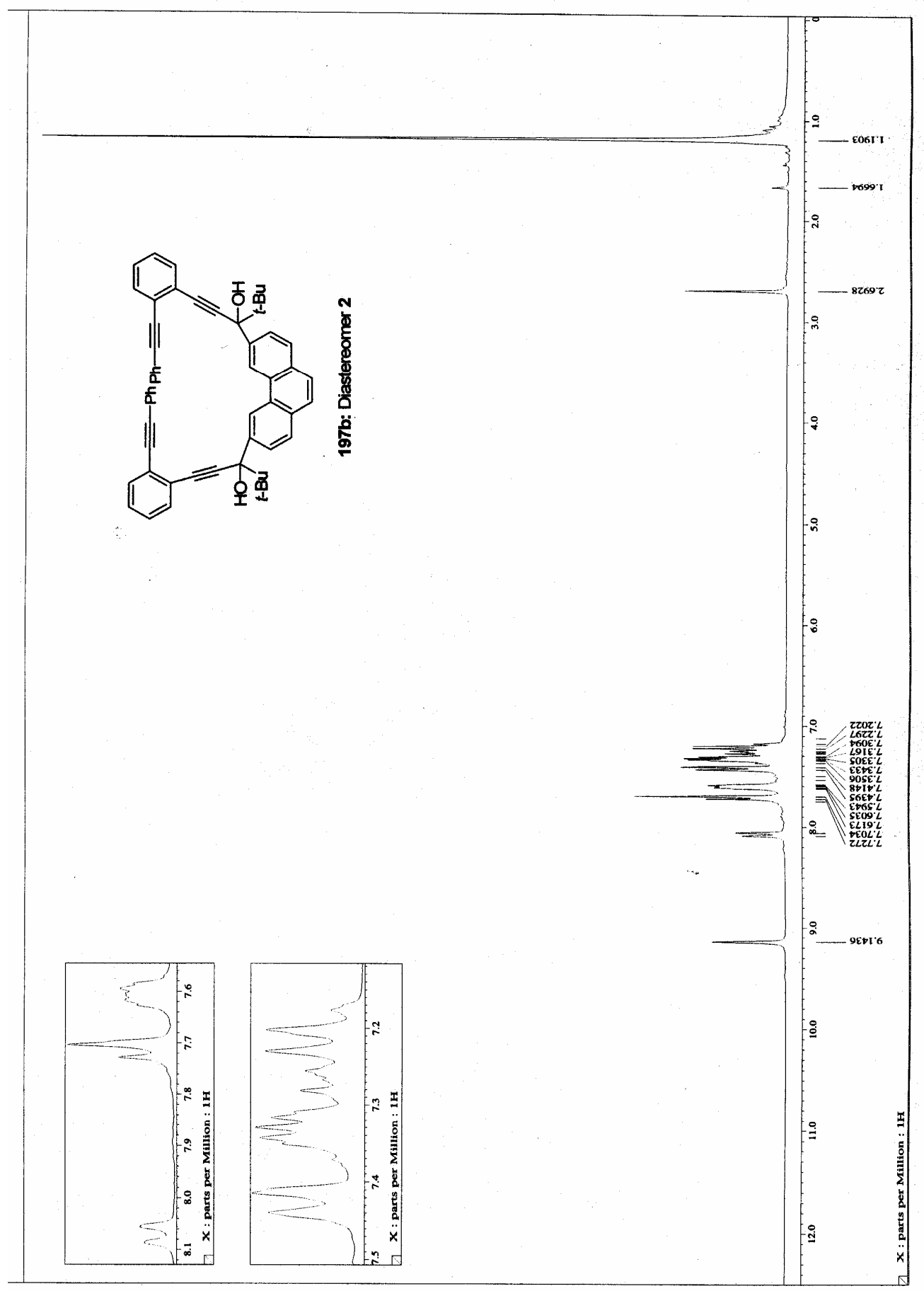




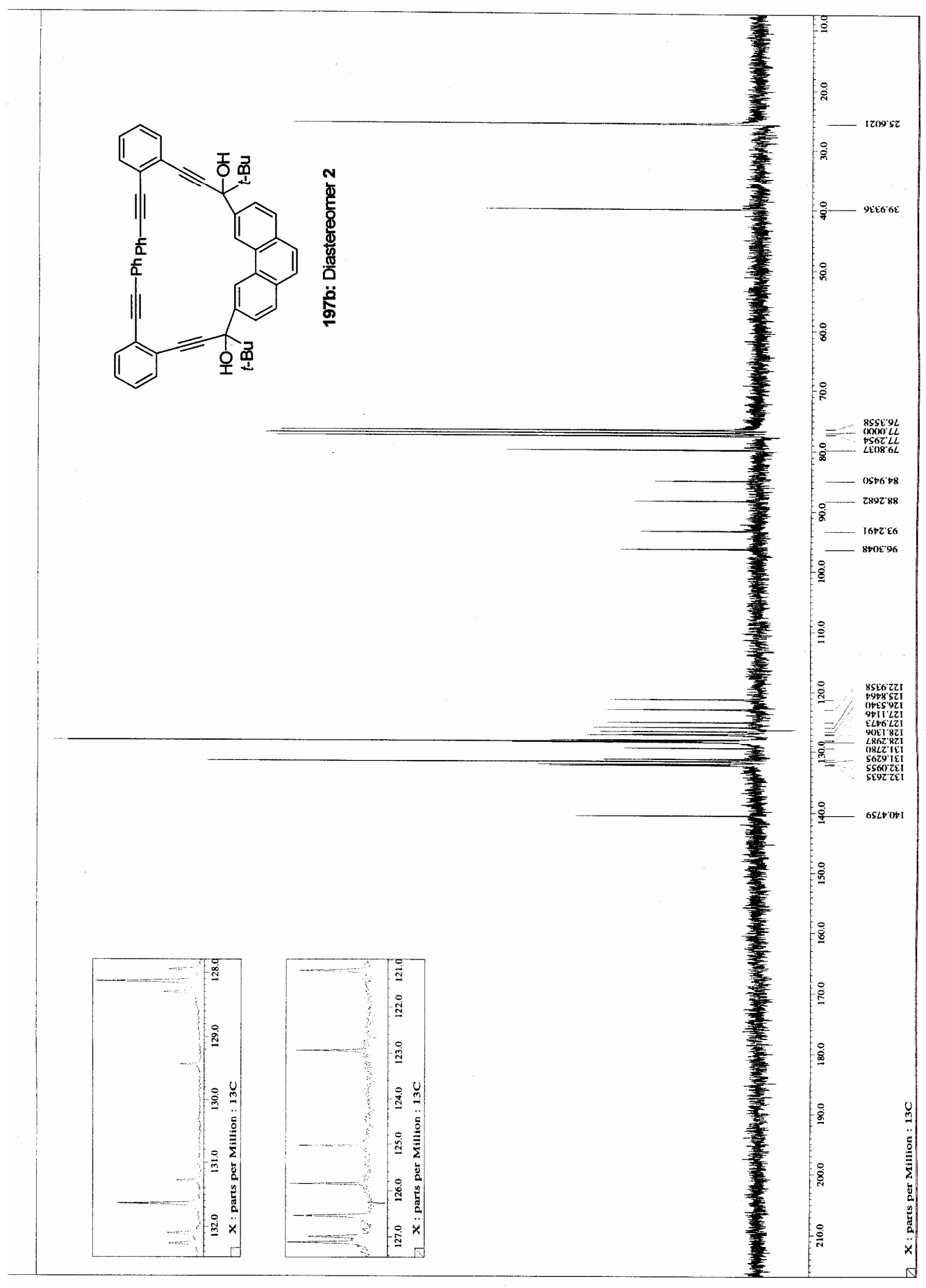




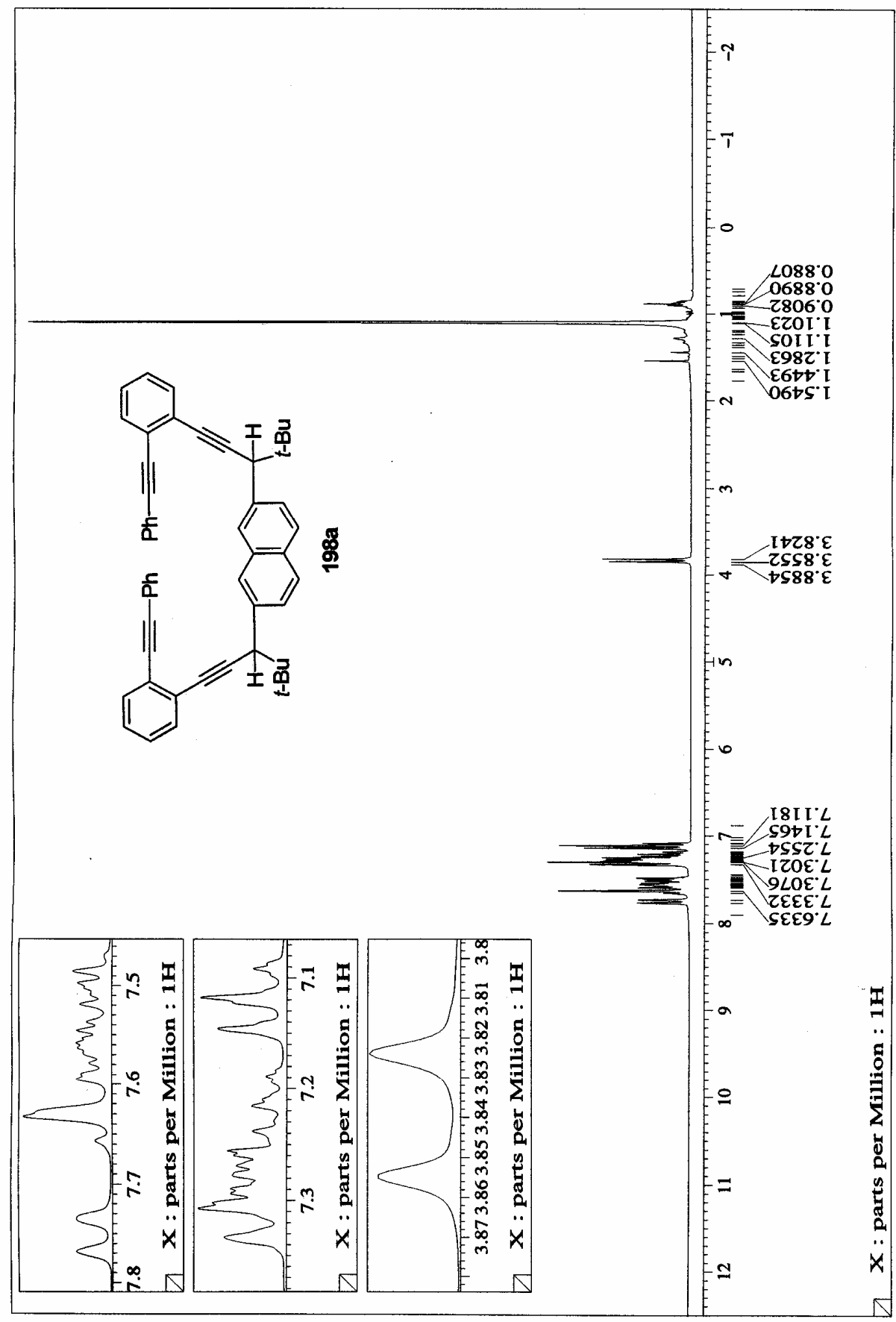




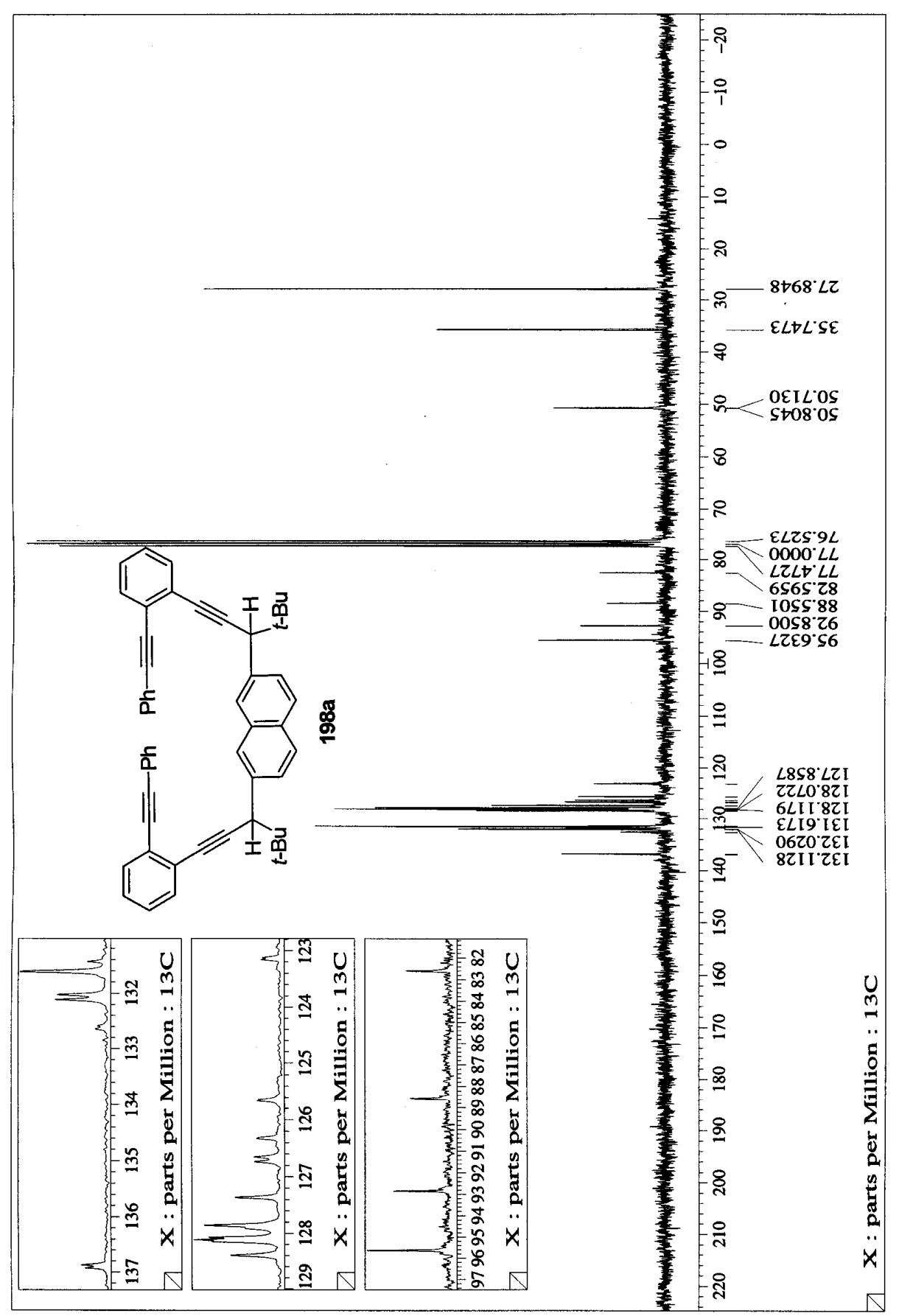




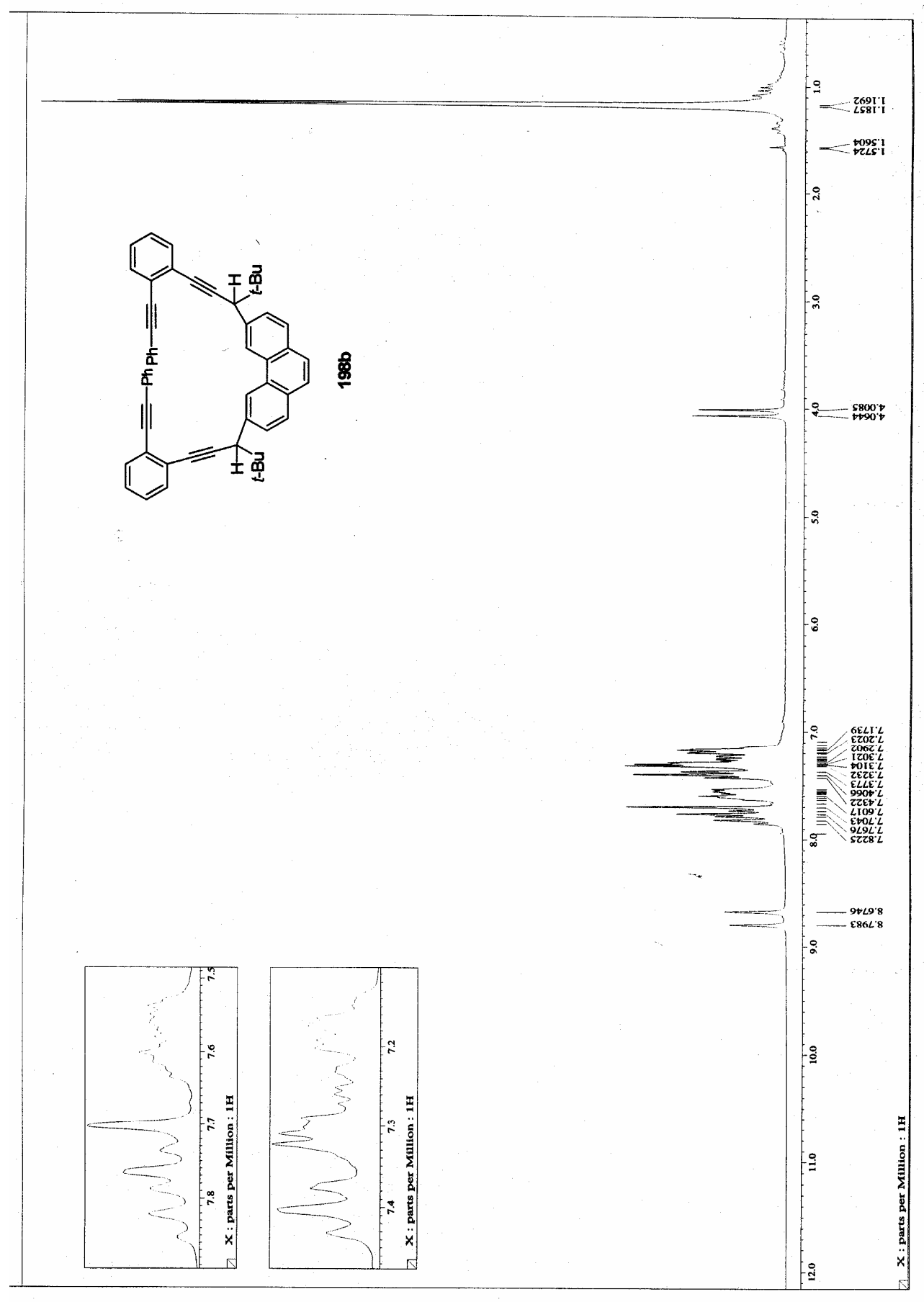




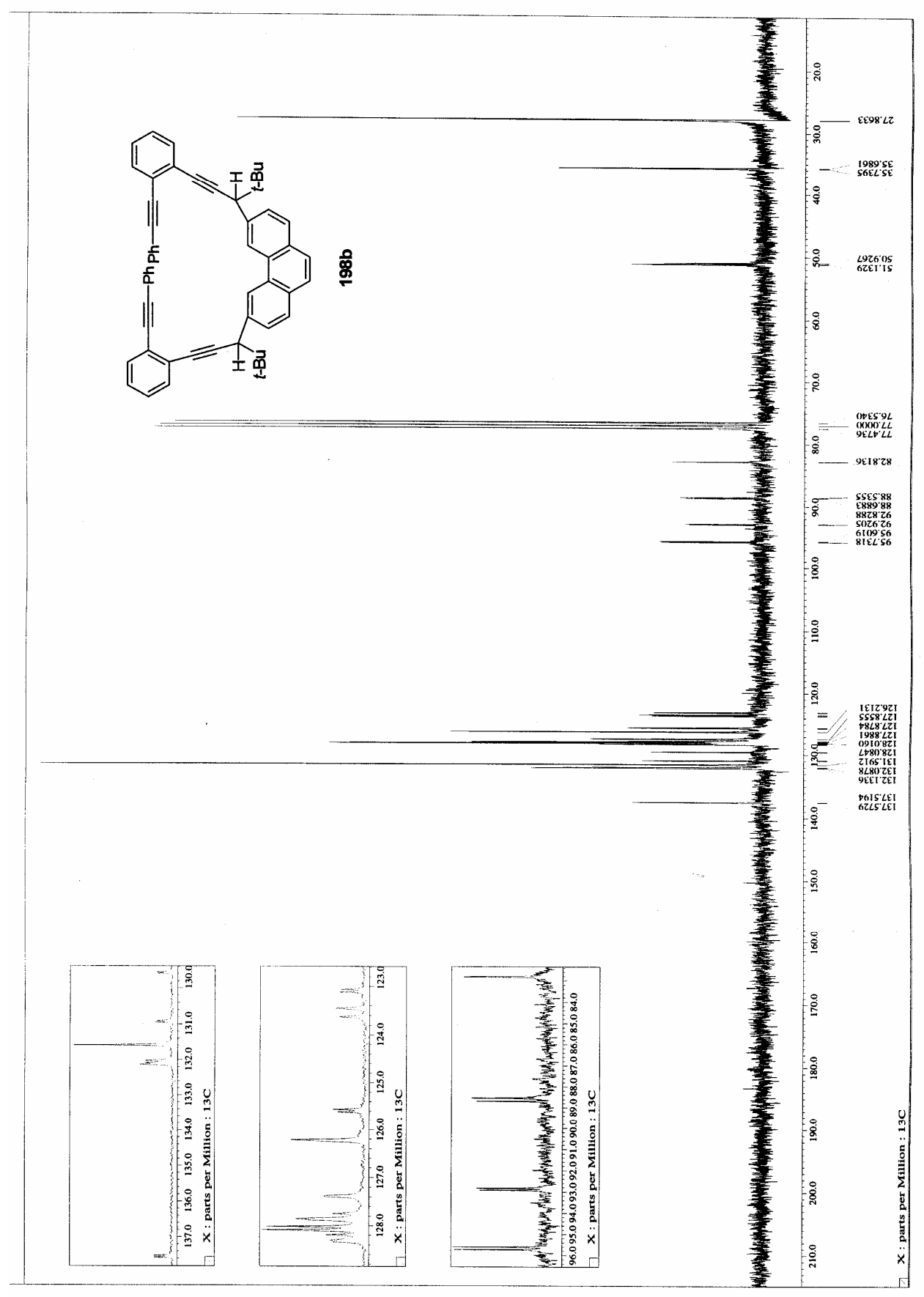




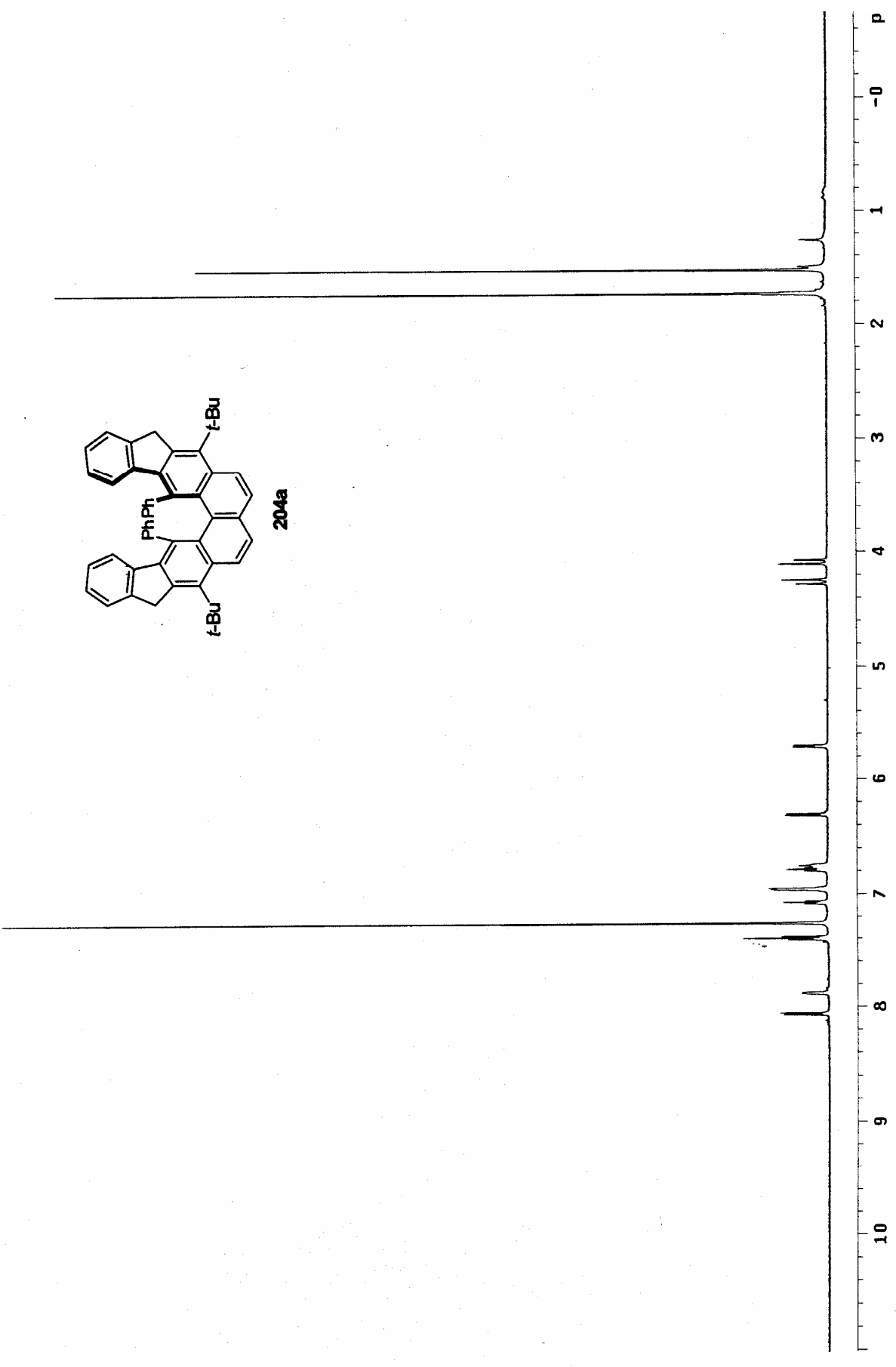




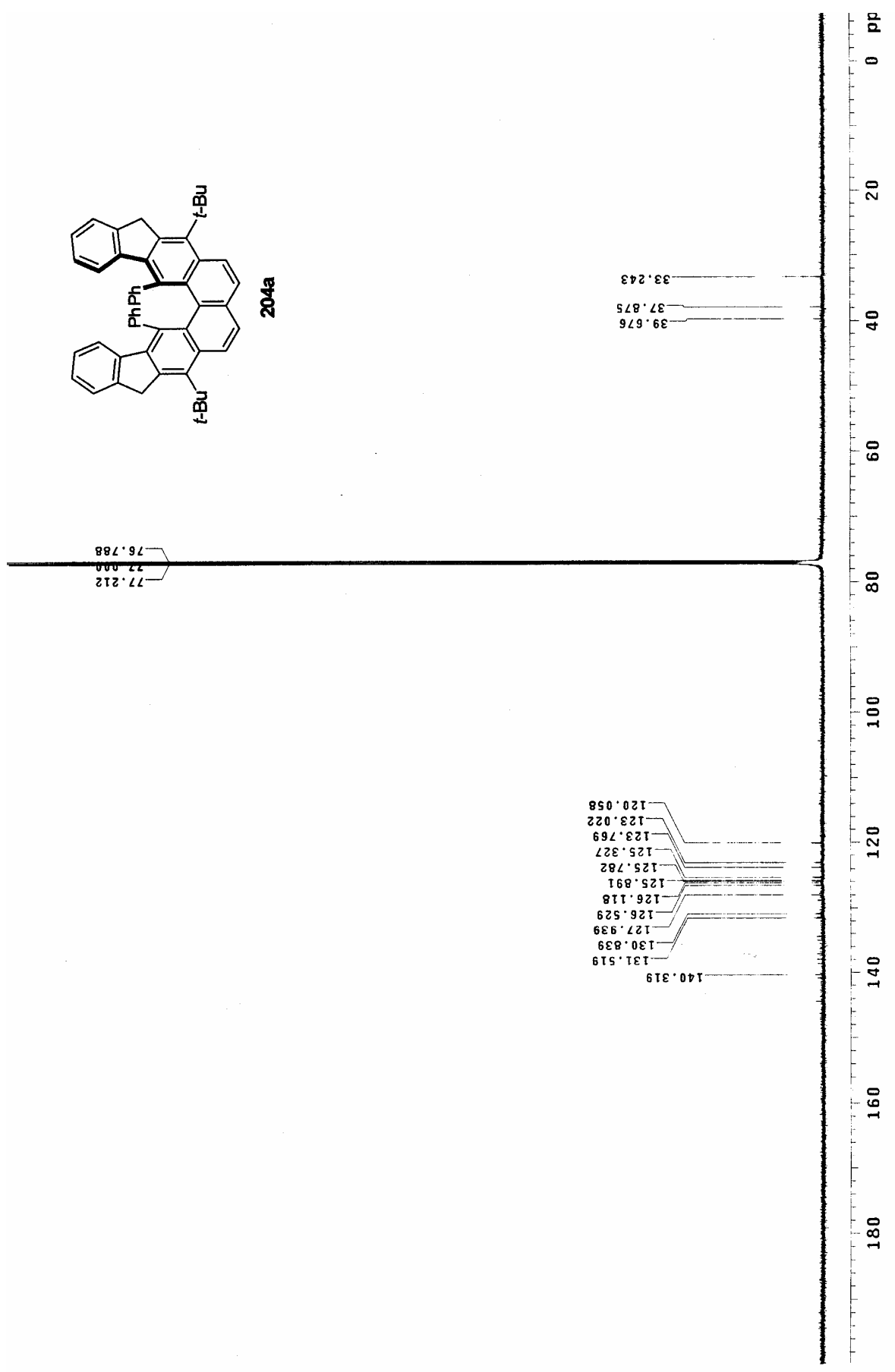




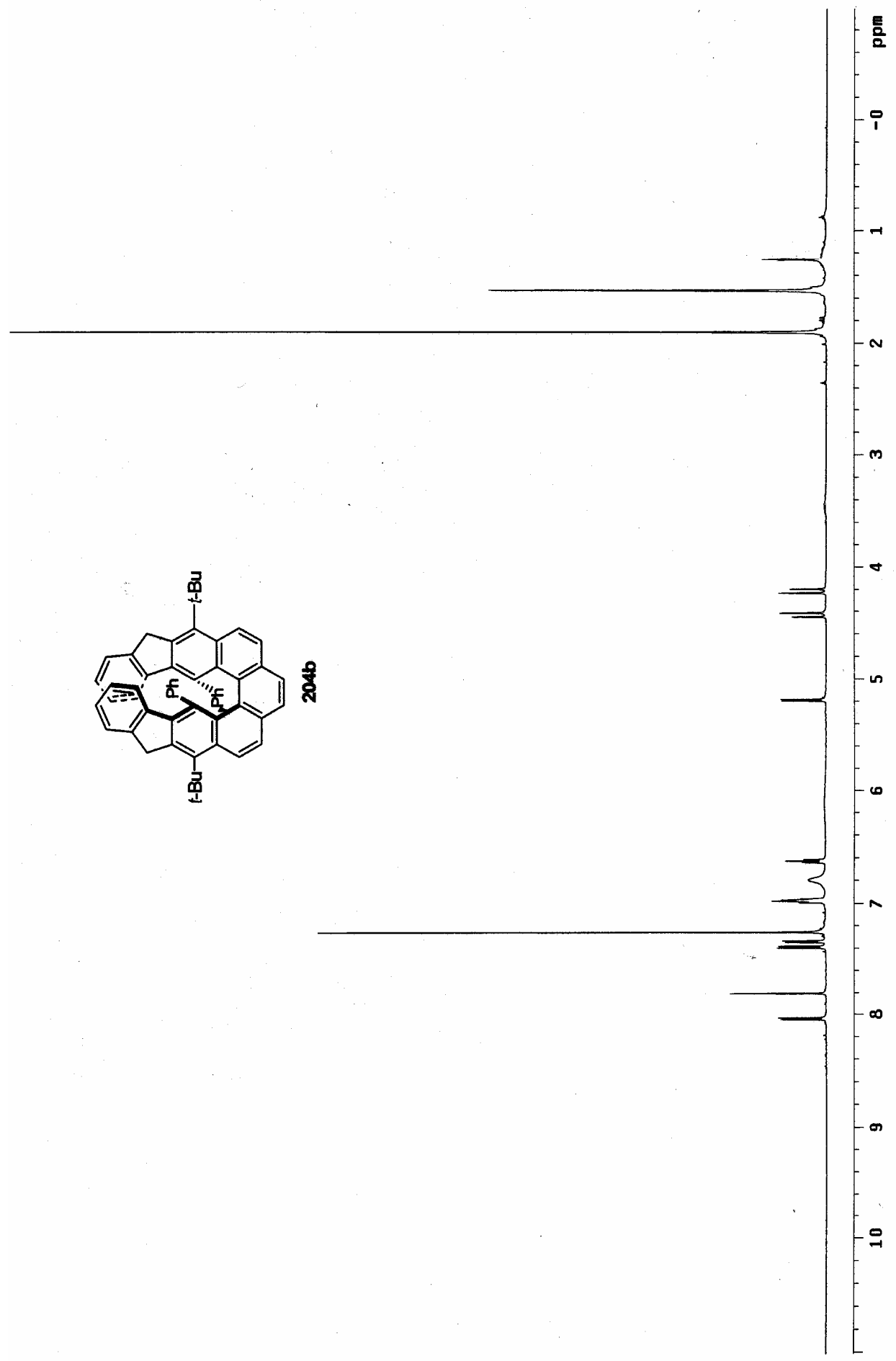

